\title{
Current Fusion Power Plant Design Concepts
}

by

B. F. Gore

E. S. Murphy

September 1976

Prepared for the Energy Research and Development Administration under Contract E(45-1)-1830

\section{कैแ Battelle}


NOTICE

This report was prepared as an account of work sponsored by the United States Government. Neither the United States nor the Energy Research and Development Administration, nor any of their employees, nor any of their contractors, subcontractors, or their employees, makes any warranty, express or implied, or assumes any legal liability or responsibility for the accuracy, completeness or usefulness of any information, apparatus, product or process disclosed, or represents that its use would not infringe privately owned rights.

PACIFIC NORTHWEST LABORATORY

operated by

BATTELLE

for the

ENERGY RESEARCH AND DEVELOPMENT ADMINISTRATION

Under Contract EY-76-C-06-7830

Printed in the United States of America

Available from

National Technical Information Service

U.S. Department of Commerce

5285 Port Royal Road

Springtield, Virginia 22151

Price: Printed Copy $\$ \_$; Microfiche $\$ 3.00$

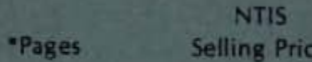

$001-025 \quad \$ 4.50$

026-050 $\quad \$ 5.00$

051-075 $\$ 5.50$

$076-100 \quad \$ 6.00$

$101-125 \quad \$ 6.50$

$126-150 \quad 57.00$

$151-175 \quad 57.75$

$176-200 \quad \$ 8.50$

201-225 $\quad 58.75$

226-250 $\$ 9.00$

$251-275 \quad \$ 10.00$

$\begin{array}{ll}276-300 & \$ 10.25\end{array}$ 
BNWL -2013

\title{
33679000624652
}

CURRENT FUSION POWER PLANT DESIGN CONCEPTS

\author{
by \\ B. F. Gore \\ E. S. Murphy
}

September 1976

Battelle

Pacific Northwest Laboratories

Richland, Washington 99352 
SUMMARY.

1.0 INTRODUCTION

1.1 Functionally-Based Descriptive Format.

1.2 Tabulation of Parameters and Materials Requirements

2.0 DESCRIPTIONS OF DESIGN CONCEPTS

2.1 Tokamak Magnetic Confinement.

2.1.1 University of Wisconsin Tokamak (UWMAK-I) .

2.1.2 Brookhaven Blanket (BNL) for UWMAK-I Tokamak

2.1.3 University of Wisconsin Tokamak UWMAK-II

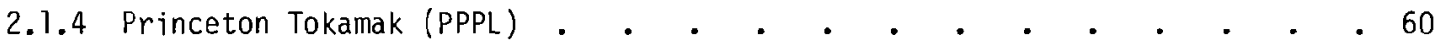

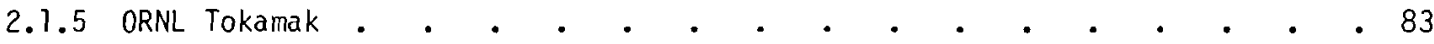

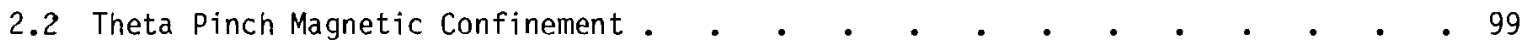

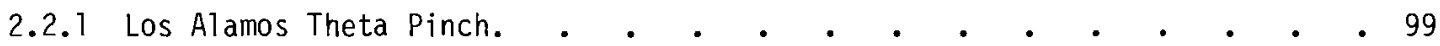

2.3 Mirror Magnetic Confinement . • • • • • • • • • • • • • • 120

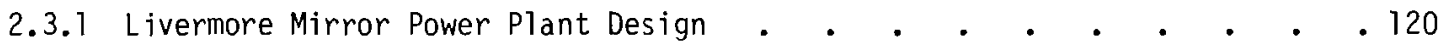

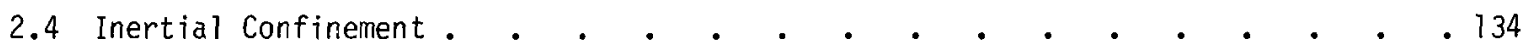

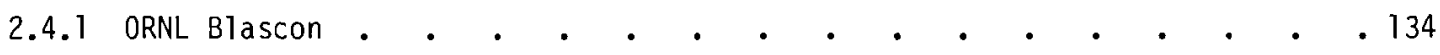

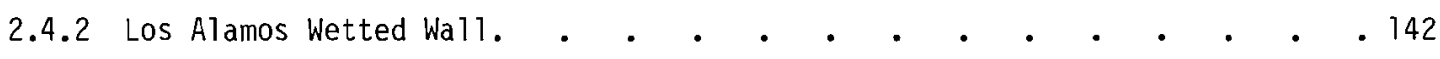

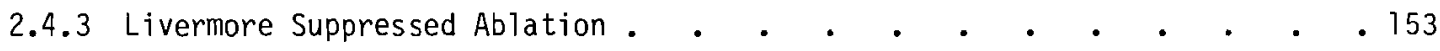

3.0 RESEARCH REQUIRED • • • • • • • • • • • • • • • • • • • • • • • • 161

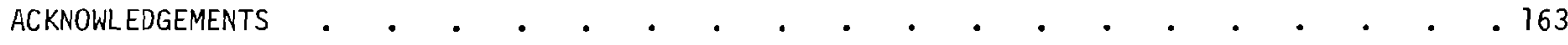

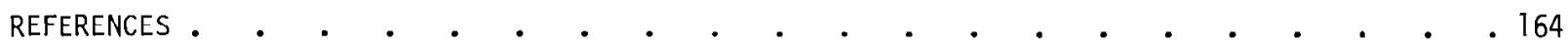




\section{LIST OF FIGURES}

Functional Relations Between Systems of the UWMAK-I Tokamak Power Plant 25

Section View of a Toroidal Module of UWMAK-I 26

Cross Section of UWMAK-I 28

Stainless Steel Structural Disc for "D" Shaped Toroidal Field Magnet in UWMAK-I 28

Reactor Cross Section of UWMAK-I Showing Locations of Transformer and Divertor Coils 29 Layer-Wound Pancake Construction of Transformer and Divertor Coils in UWMAK-I 30

Views Showing the Proposed Method for Attaching the Front Wall to the Headers 33

Isometric View of UWMAK-I Heat Removal Cells 34

Schematic of UWMAK-I Blanket, Shield and Magnet 34

Schematic of UWMAK-I Plant Design 35

Coolant Pressure Distribution in UWMAK-I 36

Bulk and Maximum Coolant Temperatures in a Radial Flow Cell in UWMAK-I 37

General Arrangement of Intermediate Heat Exchanger of the UWMAK-I 38

Steam Generator Layout for UWMAK-I 39

Flow Diagram for One of the Turbine-Generators in UWMAK-I 40

Schematic of One Divertor Liquid Lithium Coliector Plate in UWMAK-I 42

Coolant Loops for IJWMAK-I

Tritium Flow and Inventory Schematic for UWMAK-I 45

Reactor and Containment Building for LIWMAK-I 46

Functional Relations Between Systems of the BNL Blanket for the UWMAK-I Tokamak

Typical Module in BNL Blanket $\quad 48$

BNL Blanket Location $\quad 50$

Typical Arrangement of BNL Blanket Modules in Shield Slabs 50

Simplified BNL Blanket Geometry Used in Anisn Calculations 51

Bulkhead Location and Requirements of BNL Concept 53

Helium and water Coolant Loops in the BNL Concept 54

Typical Blanket Module Temperatures and Pressures for Helium Circuit in the BNL Concept 
30 Typical Blanket Module Temperatures and Pressures for Water Circuit in the BNL Concept $\quad 56$

31 Typical Getter Bed in BNL Concept 58

32 Tritium Flow and Inventory Schematic for the BNL Concept 60

33 Layout of the PPPL Tokamak Power Plant 61

34 Functional Relations Between Systems of the PPPL Tokamak Power Plant 62

35 Section View of the PPPL Tokamak 63

36 PPPL Toroidal Field Magnet Assembly 65

37 Dimensions and Configuration of the "D" Shaped Toroidal Field Coils in the PPPL Tokamak $\quad 65$

38 Magnetic Field Contours Near the Plasma in the PPPL Design . 66

39 Fuel Purification Schematic for the PPPL Tokamak 68

40 Detailed Cross Section of Radiation Shield Wall, Vacuum Wall and Inner Part of the Flibe Blanket in the PPPL Design $\quad 70$

41 PPPL Nominal Blanket Section. (View is along axis of plasma.) 70

42 Nominal Blanket Section of the PPPL Tokamak. (View is along minor circumference.) 71

43 Flibe Flow Path Through One-Half Sector of the PPPL Design 71

44 Schematic Representation of the Layered Blanket Model 72

45 The Helium Coolant System of the PPPL Design 73

46 The PPPL Tokamak Plant 74

47 Temperature Profile Along Nominal Cooling Tube 75

48 Flow Diagram for the PPPL Turbine-Generators at Full Load 78

49 Energy Flow Schematic of the PPPL Design 79

50 Divertor Magnetic Flux Surfaces in the PPPL Tokamak 79

51 Salt Processing System in the PPPL Design 80

52 Fuel Recovery System on Coolant Helium Loop in the PPPL Tokamak 81

53 Tritium Flow and Inventory Schematic of the PPPL Design 82

54 Section View of the ORNL Tokamak Power Plant 84

55 Functional Relations Between Systems of the ORNL Tokamak 85

56 Section View of the ORNL Tokamak Reactor 86

57 Magnet Coil Reinforcing Ring and Bobbin from the ORNL Design 87

58 Fuel Purification Process for the ORNL Design 89

59 Section Through the Minor Diameter of the ORNL Design 90 
60 Vertical Cross Section Through the Racetrack in the ORNL Design 90

61 Horizontal Section Through a Pair of Racetracks in the ORNL Tokamak 91

62 Potassium-Steam Binary-Vapor-Cycle Power Conversion System in the ORNL Design 94

63 Blanket Lithium Circulation System in the ORNL Tokamak. 95

64 Section Through a Reentry Tube for the Potassium Condenser-Steam Boiler of the ORNL Tokamak

65 Cold Trap System for Remvoing Tritium from the ORNL Tokamak 98

66 Tritium Flow and Inventory for the ORNL Reactor Concept 99

67 The LASL Theta Pinch Power Plant 100

68 Functional Relations Between Systems of the LASL Theta Pinch Power Plant 100

69 A LASL Theta Pinch Reactor Module 102

70 Time History of the Magnetic Field and Energy Parameters for the LASL Design 103

71 Compression Coil Windings, Insulation, and Coolant Ducts in the LASL Design 104

72 Construction Scheme for Implosion Heating Coil in the LASL Design 106

73 Flow Diagram for Cryogenic Distillation Unit in the LASL Design 107

74 Time Variation of Neutral Gas Pressure in Plasma Chamber of the LASL Theta Pinch 108

75 Detail View of a Module from the LASL Design 110

76 Lithium Flow Pattern Within a Blanket Sector of the LASL Theta Pinch 111

77 Schematic of Coolant Manifolding for a Blanket Sector of the LASL Design 111

78 Energy Conversion System of the LASL Theta Pinch 112

79 Pumping Ducts Required for Each 2-m Module in the LASL Design 115

80 Bred Tritium Recovery Process for the LASL Theta Pinch 116

81 Li/LiCl Centrifuge Contactor for the LASL Theta Pinch 116

82 Tritium Flow and Inventory for the LASL Design 117

83 Elevation View of the Theta Pinch Power Plant 118

84 Plan View of the Theta Pinch Power Plant 119

85 Conceptual LLL Mirror Reactor with Direct Conversion 121

86 Functional Relations Between Systems of the LLL Mirror Power Plant 121

87 Cutaway View of the LLL Mirror Design 122

88 Magnet and Blanket Configuration of the LLL Design 122

89 Dimensions of Coils in the LLL Design 124

90 The Neutral-Beam Injection System of the LLL Mirror N sign 126 
91 Approximate Model of Blanket Geometry Used in Neutronic Analysis for the LLL Mirror

94 Power Flow Diagram for the LLL Mirror Reactor (A11 Powers are in MW)

95 Tritium Flows in the LLL Mirror Power Plant

97 Functional Relations Between Systems of the ORNL Blascon Laser-Pellet Power Plant

100 Muffler System of the Blascon Design

103 Overall Plant Layout of the LASL Conceptual Laser-Fusion Power Plant

104 Functional Relations Between Systems of the LASL Wetted Wal1 Laser-Pellet Power Plant

105 Cross Section and Flow Schematic of the LASL Wetted Wall Laser-Pellet Design

107 Power Plant Layout for the LASL Laser-Fusion Concept

108 Optical System for Delivery of Laser Pulse to LASL Laser-Fusion Reactor Cavity

109 Laser Beam Tubes for Symmetrical Pellet Irradiation in the LASL Design

110 Pellet Fabrication and Injection System for the LASL Laser-Fusion Reactor

111 Power Plant Layout for LASL Laser-Fusion Concept

112 Tritium Flow Schematic for the LASL Laser-Fusion Power Plant

113 Reactor Chamber and Service Assembly of the Suppressed Ablation Laser-Pellet Reactor

114 Functional Relations Between Systems of the LLL Suppressed Ablation Power Plant

115 Reactor Chamber and Blanket Element in the Suppressed-Ablation Reactor

116 Power Flow Diagram for a laser-Induced Fusion Reactor Power Plant Consisting of 10 Reactors. (A11 powers are in megawatts.) 


\section{LIST OF TABLES}

1 Originators of Conceptual Power Plant Designs

2 Fusion Power Plant Design Parameters 6

3 Fusion Power Plant Material Requirements for Construction 17

4 Fusion Power Plant Material Requirements for Operation 18

5 Normalized Fusion Power Plant Design Parameters, Per 1000 MWE Net Output 19

6 Normalized Fusion Power Plant Material Requirements for Construction, Per 1000 MWe Net Output 20

7 Normalized Fusion Power Plant Material Requirements for Operation 21

8 UWMAK-I Tritium Inventory 44

9 BNL Concept Tritium Inventory 59

10 Hot Leg Duct Parameters $\quad 75$

11 Cold Leg Duct Parameters $\quad 76$

12 The PPPL Tokamak Tritium Inventory 12

13 Position and Thickness of the ORNL Blanket and Shield Components 92

14 ORNL Power Plant Tritium Inventory 98

15 LASL Power Plant Tritium Inventory 117

16 Material Compositions for the Blanket and Shield of the LLL Design 128

17 Environmental Interactions, and Design Information Required for Their Analysis 162 


\section{SUMMARY}

Nine current-U.S. designs for fusion power plants are described in this document. Summary tabulations include a tenth concept, for which the design document was unavailable during preparation of the descriptions. The information contained in the descriptions was used to define an envelope of fusion power plant characteristics which formed the basis for definition of reference first commercial fusion power plant design. (1) That reference design was the subject of the environmental analysis which this document supports.

The power plant designs described herein share many similarities because the basic functions that must be performed for the operation of deuterium-tritium fueled power plants are similar. Specifically, a fusioning plasma must be confined, heated and fueled; neutron and radiation energy must be captured and converted to heat in a blanket surrounding the plasma; the blanket must be cooled and the heat transported to a thermal-cycle generating system; and the tritium must be recovered from unburned plasma and from blanket materials where it is bred from $1 \mathrm{ithium}$ for recycle to the plasma. Consequently, the descriptions are organized around these functional requirements. Systems performing each of the basic functions are described. This organizational format was chosen to emphasize similarities between the concepts, and to facilitate comparison of differences between systems designed to perform a given function.

A brief prose summary of primary plant features introduces each of the descriptions contained in the body of this document. In addition, summary tables are presented in Section 1.2. These tables summarize in side-by-side fashion, plant parameters, processes, combinations of materials used, requirements for construction materials, requirements for replacement materials during operation, and production of wastes.

Additional summary information, of both prose and tabular nature, is contained in BNWL-2014. In that companion document an envelope of fusion power plant design characteristic (normalized to the production of 1000 MWe net electrical output) is defined.

\section{Research Requirements}

Preparation of an adequate environmental analysis for a power plant requires a description of that power plant with sufficient detail to permit reasonable estimation of the interactions with the environment. The present design concepts do not contain sufficient design detail, particularly for the plant subsystems controlling releases to the environment. Future descriptions of design concepts should include specific information such as:

- Process flow diagrams showing the flow paths and rates of all major materials (fuels, coolants, wastes),

- A description of the entire fuel cycle from mine to disposal of the wastes,

- Sufficient descriptive material so that all radioactive inventories and their flow paths and rates are known, 
- A general description of a 11 major supporting subsystems (waste treatment, ventilation, power generation),

- Sufficient descriptions of any equipment that controls the release rates of pollutants so that the release rates can be determined,

- Any unique siting or construction requirements, and

- A tabulation of the quantities of each significant construction material showing location and degree of fabrication.

During the preparation of the designs, emphasis should be placed on minimizing the environmental effects. Of particular importance is reducing material use per unit of plant capacity since the primary adverse impact of fusion power plants may be material use.

Establishment of a standard format for describing fusion power plant designs would facilitate identification of missing information and preparation of environmental analyses. 


\subsection{INTRODUCTION}

The fusion power plant designs which are described in this document share many similarities, yet they also differ greatly. All of the designs are for deuterium-tritium fueled plants. Hence many basic functions required of plant systems are similar. The breeding of tritium fuel from lithium is required, and in all cases its recovery and processing is performed within the plant. Massive structures and shielding are required to stop the energetic neutrons released in D- $T$ fusion. All of the designs use standard thermal cycle electricity generating systems.

The descriptions contained herein were prepared according to a common format based upon their functional similarities. This format is described in Section 1.1. Systems performing each of the basic functions are described. This organizational format was chosen to emphasize similarities between the concepts, and to facilitate comparison of differences between systems designed to perform a given function.

As is discussed in the fusion research program review, (2) a variety of methods is being investigated to achieve the fundamental goal of fusion research which is to create a plasma of thermonuclear temperature and density, and to hold it together long enough that more energy is released in fusion than is expended in creating the plasma. Plasma confinement by magnetic fields is used in tokamak, theta pinch and mirror concepts. Plasma confinement due to the inertia of the plasma itself is used in laser-pellet concepts.

Plasma confinement and heating systems are central features of fusion power reactor designs. The methods and equipment used to confine and heat the fusioning plasma in a fusion power reactor significantly constrain the geometry of the plasma chamber, the duration of the thermonuclear burn, the rate of energy deposition in the blanket surrounding the plasma chamber, and the positioning, thickness and functioning of materials in the reactor blanket surrounding the plasma chamber. Thus, the methods chosen for plasma confinement and heating are primary sources of differences between the design concepts. Other sources of differences include the processes chosen to perform other necessary functions, the completeness of the designs, the materials specified, and assumptions of technological capabilities exceeding those presently available.

Conceptual power plant designs have been developed for each of the major confinement concepts under investigation. Four designs are included for power plants based on tokamak confinement, presently considered to be the most promising method of magnetic confinement. The designs were developed by study groups at the laboratories listed in Table 1.

The UWMAK-I from the University of Wisconsin is the first published complete Tokamak design, starting from basic plasma conditions. The BNL blanket is designed for the UWMAK-I plasma systems. Although the BNL blanket design is quite recent and less complete than others, it is described here because of the features which it shares with UWMAK-I. The UWMAK-II Tokamak design from the University of Wisconsin employs solid lithium compounds and helium gas cooling. The UWMAK-II design document was not available when the descriptions were prepared; therefore it is not described in the text. The PPPL Tokamak design is another early design derived from plasma conditions outward and uses helium cooling. The ORNL Tokamak blanket design begins with plasma conditions assumed on the basis of other ORNL studies, and addresses primarily the blanket and shield regions of the reactor. The order of presentation for these design concepts is arbitrarily based on the chronological order of publication. 
TABLE 1 Originators of Conceptual Power Plant Designs

Magnetic Confinement

\begin{tabular}{ll}
\hline Tokamak & $\begin{array}{l}\text { University of Wisconsin (UWMAK) }(3,4) \\
\text { Brookhaven National Laboratory }(B N L)(5) \\
\text { Princeton Plasma Physics Laboratory }(\mathrm{PPPL})(6) \\
\text { Oak Ridge National Laboratory (ORNL) }\end{array}$ \\
$\begin{array}{l}\text { Los Alamos Scientific Laboratory (LASL) } \\
\text { Theta Pinch }\end{array}$ & Lawrence Livermore Laboratory (LLL) \\
Mirror & \\
Inertial Confinement & ORNL (10) \\
Blascon & LASL (11) \\
Wetted Wal1 & LLL (12) \\
Suppressed Ablation &
\end{tabular}

\subsection{Functionally-Based Descriptive Format}

Each power plant design description contained in this document has been prepared according to the following format:

- Summary Description

- Plasma Confinement System

- Plasma Heating System

- Fuel System

- Blanket
- Heat Transfer System

- Electricity Generation Systems

- Spent Plasma Collection System

- Bred Tritium Recovery System

- Containment Building

Figure 1 shows functional relations between the major plant systems. Brief descriptions of the functions of these systems follow.

The Plasma Confinement System holds the fusioning plasma together at thermonuclear temperatures and densities long enough to release more fusion energy than is expended in creating the plasma, and confines unburned fuel and reaction products exiting from the burn region for subsequent recovery.

The Plasma Heating System delivers large amounts of energy to the plasma, thus heating it to near-solar temperatures.

The Fuel System purifies recycled D-T fuel, prepares it in the form necessary for use, and injects the appropriate quantity into the plasma chamber at the appropriate time and velocity.

The Blanket of material surrounding the plasma chamber performs many functions. It:

- Converts neutron energy to heat,

- Breeds tritium fuel by neutron interactions with lithium,

- Contains the fuel and other particles escaping from the plasma,

- Provides a vacuum chamber for the plasma (in some cases), 


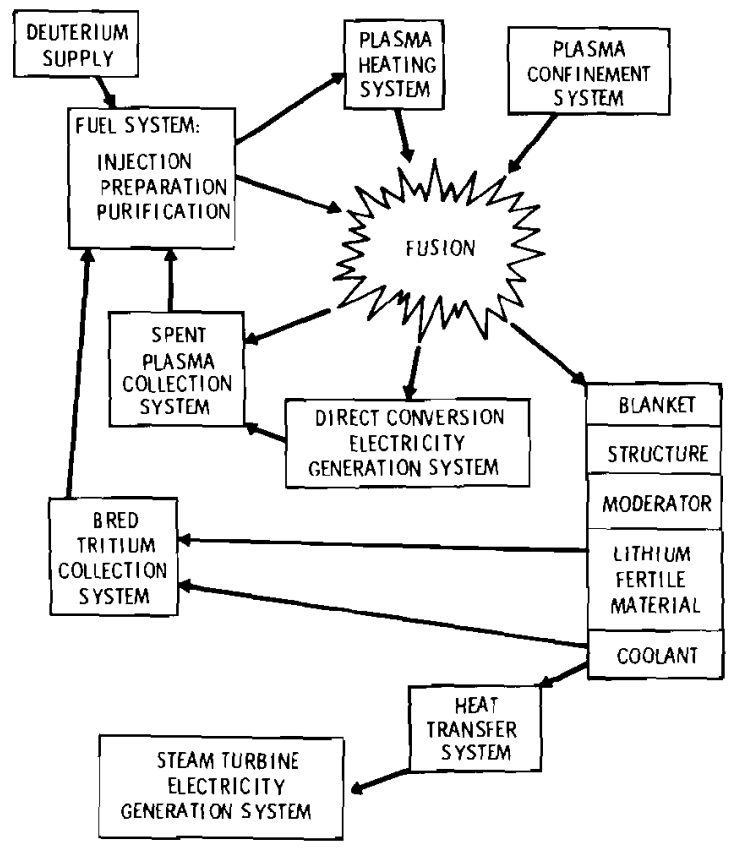

FIGURE 1 Functional Relations Between Major Plant Systems

- Shields outer structures from fusion neutrons and other energy sources,

- Contains tritium bred within it, and

- Contains the coolant which transports heat from the blanket.

The Heat Transfer System removes heat from blanket materials and transports it to the electricity generating system. It contains and circulates the coolants, and confines any radioactive matetials that are entrained therein.

Electricity Generation Systems convert heat energy to electricity using turbine-generators. In addition, they may directly convert the kinetic energy of charged particle motion into electricity without conversion to heat and the use of a thermodynamic cycle.

The Spent Plasma Collection System collects escaping plasma particles during and after the thermonuclear burn. Since only a small fraction of the fuel in the plasma is consumed this system recycles collected plasma to the fuel system.

The Bred Tritium Recovery System recovers tritium bred by neutron interactions in blanket materials, and delivers it to the fuel system.

\subsection{Tabulation of Parameters and Materials Requirements}

These tables present the major features of the ten U.S. fusion power plant designs described in this document. Additional summary information is contained in BNWL-2014. (1) In that companion document an envelope of fusion power plant design characteristics [normalized to the production of 1000 megawatts electric (MWe) net electrical output] is defined. 
Power Plant Parameters - Principal fusion power plant parameters are identified and tabulated in Table 2. Information is not included in these tables if it is not available or not applicable. Material Requirements for Construction - These requirements are listed in Table 3 . Replacement materials required after plant startup are not included.

Material Requirements for Operation - Average annual requirements for materials required to replace blanket structures damaged by radiation are listed in Table 4.

Quantities per 1000 MWe - The net electrical power output of the designs described in this document ranges from 170 to 4130 MWe. Therefore direct comparison of size-dependent parameter values can be misleading. Consequently, additional tables of normalized size-dependent parameters are also included. Table 5 presents normalized plant parameters, and Tables 6 and 7 present norma1ized construction and operating material requirements, all normalized per 1000 MWe of net electrical output.

$\underline{\text { TABLE } 2}$ Fusion Power Plant Design Parameters

\begin{tabular}{|c|c|c|c|c|c|c|c|c|c|c|}
\hline $\begin{array}{l}\text { Power Plant } \\
\text { Parameters }\end{array}$ & UWMAK-I & $\begin{array}{l}\text { BNL } \\
\text { Blanket }\end{array}$ & UWMAK-II & PPPL & ORNL & $\begin{array}{l}\text { Theta } \\
\text { Pinch }\end{array}$ & Mirror & Blascon & $\begin{array}{l}\text { Wet } \\
\text { Wall }\end{array}$ & $\begin{array}{l}\text { Suppressed } \\
\text { Ablation }\end{array}$ \\
\hline $\begin{array}{l}\text { Net electrical } \\
\text { power output, } \\
\text { MWe }\end{array}$ & 1473 & 1605 & 1710 & 2030 & 518 & 4132 & 170 & Unspecified & 1000 & 270 \\
\hline $\begin{array}{l}\text { Nuclear thermal } \\
\text { power, MWt }\end{array}$ & 4663 & 5000 & 4712 & 5305 & 1000 & 12000 & 640 & 4800 & 3745 & 760 \\
\hline $\begin{array}{l}\text { Net plant } \\
\text { efficiency, } \%\end{array}$ & 32 & 32 & 30 & 38 & 52 & 34 & 27 & - & 27 & 36 \\
\hline $\begin{array}{l}\text { Total electrical } \\
\text { power gener- } \\
\text { ated, MWe }\end{array}$ & 1682 & 1719 & 1807 & 2405 & 564 & 5100 & 740 & 1920 & 1500 & 370 \\
\hline $\begin{array}{l}\text { Electrical power } \\
\text { from direct } \\
\text { conversion, } \\
\text { MWe }\end{array}$ & 0 & 0 & 0 & 0 & 0 & 1152 & 430 & 0 & 0 & 0 \\
\hline $\begin{array}{c}\text { Gross Thermal } \\
\text { efficiency, \% }\end{array}$ & 36 & 34 & 38 & 45 & 56 & 42 & 65 & 40 & 40 & 49 \\
\hline $\begin{array}{l}\text { Generation } \\
\text { interruptions } \\
\text { due to burn } \\
\text { cycle }\end{array}$ & none & $\begin{array}{l}6.5 \mathrm{~min} \\
\text { every } \\
96.5 \mathrm{~min}\end{array}$ & none & none & $\begin{array}{l}20 \mathrm{sec} \\
\text { every } \\
172 \mathrm{sec}\end{array}$ & none & none & none & none & none \\
\hline $\begin{array}{c}\text { Thermonuclear } \\
\text { burn cycle } \\
\text { period, min }\end{array}$ & $\begin{array}{l}90 \mathrm{~min} \\
\text { burn in } \\
96.5 \mathrm{~min} \\
\text { total cycle }\end{array}$ & $\leftarrow$ & $\begin{array}{l}90 \text { min } \\
\text { burn in } \\
98 \text { min } \\
\text { total cycle }\end{array}$ & $\begin{array}{l}97 \text { min } \\
\text { burn in } \\
100 \text { min } \\
\text { total cycle }\end{array}$ & $\begin{array}{l}152 \mathrm{sec} \\
\text { burn in } \\
172 \mathrm{sec} \\
\text { total cycle }\end{array}$ & $\begin{array}{l}70 \text { msec } \\
\text { burn in } \\
3 \mathrm{sec} \\
\text { total cycle }\end{array}$ & Continuous & $\begin{array}{l}0.5 \text { micro } \\
\text { explosions } \\
\text { per second, } \\
\text { per cavity }\end{array}$ & $\begin{array}{l}1.7 \text { micro } \\
\text { explosions } \\
\text { per second, } \\
\text { per cavity }\end{array}$ & $\begin{array}{l}10 \text { micro } \\
\text { explosions } \\
\text { per second, } \\
\text { per cavity }\end{array}$ \\
\hline $\begin{array}{l}\text { Generation } \\
\text { inter ruptions } \\
\text { due to inner } \\
\text { wall main- } \\
\text { lenance }\end{array}$ & $\begin{array}{l}6 \text { wh outage } \\
\text { every } 2 \text { yr } \\
\text { to replace } \\
\text { inner blanket }\end{array}$ & $\begin{array}{l}1 \text { mo outage } \\
\text { each year } \\
\text { to replace } \\
1 / 3 \text { of } \\
\text { blanket }\end{array}$ & $\begin{array}{l}28 \mathrm{~d} \text { each } \\
6 \text { mo to } \\
\text { replace } 1 / 4 \\
\text { of blanket }\end{array}$ & $\begin{array}{l}\text { Replace } 1 / 5 \\
\text { blanket } \\
\text { annually; } \\
85 \% \text { avail- } \\
\text { ability factor }\end{array}$ & $\begin{array}{l}\text { Replace } \\
\text { blanket } \\
\text { every } 10 \\
\text { yr, } 2 \text { wk } \\
\text { shutdown/yr }\end{array}$ & $\begin{array}{l}5 \text { yr module } \\
\text { life; } \\
\text { estimated } \\
\text { replacement } \\
\text { time. } 1 \mathrm{hr}\end{array}$ & & & & \\
\hline
\end{tabular}


TABLE 2 (contd)

\begin{tabular}{|c|c|c|c|c|c|c|c|c|c|c|}
\hline $\begin{array}{l}\text { Reactor } \\
\text { Parameters } \\
\end{array}$ & UWMAK-1 & $\begin{array}{l}\text { BNL } \\
\text { Blanket }\end{array}$ & UWMAK-II & PPPL & ORNL & $\begin{array}{l}\text { Theta } \\
\text { Pinch }\end{array}$ & Mirror & Blascon & $\begin{array}{l}\text { Wet } \\
\text { Wall }\end{array}$ & $\begin{array}{l}\text { Suppressed } \\
\text { Ablation }\end{array}$ \\
\hline $\begin{array}{l}\text { Reactor } \\
\text { configuration }\end{array}$ & Toroid & + & Toroid & Toroid & Toroid & Toroid & Sphere & $\begin{array}{l}12 \text { separate } \\
\text { spheres }\end{array}$ & $\begin{array}{l}24 \text { separate } \\
\text { spheres }\end{array}$ & $\begin{array}{l}10 \text { separate } \\
\text { icosahedra }\end{array}$ \\
\hline $\begin{array}{l}\text { Greatest linear } \\
\text { dimension, } m\end{array}$ & 43 & + & & 35 & 30 & 115 & 32 & 8 & 5.8 & 7 \\
\hline $\begin{array}{l}\text { Plasma chamber } \\
\text { dimensions, } m\end{array}$ & $\begin{array}{l}\text { Major } R, 13 \\
\text { minor } R, 5.5\end{array}$ & $\leftarrow$ & $\begin{array}{l}\text { Major } R, 13 \\
\text { minor } R, 5.5\end{array}$ & $\begin{array}{l}\text { Major } R, 11 \\
\text { minor } R, 3.6\end{array}$ & $\begin{array}{l}\text { Major } R, 10.5 \\
\text { minor } R, 3.5\end{array}$ & $\begin{array}{l}\text { Major R, } 56 \\
\text { minor R, } 0.5\end{array}$ & $R, 4.4$ & vortex $R, 0.4$ & $\mathrm{R}, 1.7$ & $R, 2.2$ \\
\hline $\begin{array}{l}\text { Plasma } \\
\text { Parameters } \\
\end{array}$ & UWMAK-1 & $\begin{array}{l}\text { BNL } \\
\text { Blanket }\end{array}$ & UWMAK-II & PPPL & ORNL & $\begin{array}{l}\text { Theta } \\
\text { Pinch }\end{array}$ & Mirror & Blascon & $\begin{array}{l}\text { Wet } \\
\text { Wall } \\
\end{array}$ & $\begin{array}{l}\text { Suppressed } \\
\text { Ablation }\end{array}$ \\
\hline $\begin{array}{l}\text { Avg. ion } \\
\text { temperature, } \\
\text { keV }\end{array}$ & 11.1 & $\leftarrow$ & 13.2 & 30 & 20 & 6.1 & 620 & & & \\
\hline $\begin{array}{l}\text { Avg. electron } \\
\text { temperature, } \\
\text { keV }\end{array}$ & 11.0 & $\leftarrow$ & 12 & 20 & 20 & 6.1 & 84 & & & \\
\hline $\begin{array}{l}\text { Hydrogen ion } \\
\text { density at } \\
\text { ignition, } \mathrm{cm}^{-3}\end{array}$ & $8 \times 10^{13}$ & + & $7.3 \times 10^{13}$ & $5 \times 10^{13}$ & $5 \times 10^{13}$ & $2.5 \times 10^{16}$ & $1.2 \times 10^{14}$ & & & \\
\hline $\begin{array}{l}\text { Confinement } \\
\text { time, sec }\end{array}$ & 14.2 & $\leftarrow$ & 3.6 & 3.8 & Neo-classical & 0.08 & & & & \\
\hline $\begin{array}{l}\text { Ion ratios } \\
D / T / \text { (impurity) }\end{array}$ & $1: 1: 0.019$ (Ar) & 14 & $1: 1$ & $\begin{array}{l}1: 1: 0.096 \\
(A r)\end{array}$ & $1: 1$ & $1: 1$ & 1:1 & & $1: 1$ & $1: 1$ \\
\hline $\begin{array}{l}\text { Avg. pressure } \\
\text { ratio } \beta\end{array}$ & 0.052 & $\leftarrow$ & 0.056 & 0.04 & $<0.15$ & 1 & 0.85 & & & \\
\hline Avg. poloidal $\beta_{\Theta}$ & 1.08 & $\leftarrow$ & 2.3 & 1.83 & 3 & & & & & \\
\hline Aspect ratio, A & 2.6 & $\leftarrow$ & 2.6 & 3.23 & 3.75 & & & & & \\
\hline $\begin{array}{l}\text { Plasma current, } \\
\text { MA }\end{array}$ & 21 & $\leftarrow$ & 14.9 & 14.6 & 10 & & & & & \\
\hline $\begin{array}{l}\text { Current safety } \\
\text { factor, Q }\end{array}$ & 1.75 & $\leftarrow$ & 2.3 & 2.1 & 1.4 & & & & & \\
\hline $\begin{array}{l}\text { Kinetic energy } \\
\text { content, } \\
\text { gigajoules }\end{array}$ & 3 & & & & & & & & & \\
\hline $\begin{array}{l}\text { Microexplosion } \\
\text { energy release, MJ }\end{array}$ & & & & & & & & 800 & 100 & 7 \\
\hline $\begin{array}{l}\text { Magnetic } \\
\text { Parameters }\end{array}$ & UWMAX-I & $\begin{array}{l}\text { BNL } \\
\text { Blanket }\end{array}$ & UWMAK-II & PPPL & ORNL & $\begin{array}{l}\text { Theta } \\
\text { Pinch }\end{array}$ & Mirror & Blascon & $\begin{array}{l}\text { Wet } \\
\text { Wall } \\
\end{array}$ & $\begin{array}{l}\text { Suppressed } \\
\text { Ablation }\end{array}$ \\
\hline $\begin{array}{l}\text { Principal } \\
\text { confining } \\
\text { magnetic field }\end{array}$ & Toroidal & $\leftarrow$ & Toroidal & Toroidal & Toroidal & $\begin{array}{l}\text { Toroidal } \\
\text { (compression } \\
\text { field) }\end{array}$ & $\begin{array}{l}\text { Yin Yang } \\
\text { coils; } \\
\text { magnetic } \\
\text { well with } \\
\text { open mirrors }\end{array}$ & & & \\
\hline $\begin{array}{l}\text { Magnet coils, } \\
\text { number }\end{array}$ & 12 & $\leftarrow$ & 24 & 48 & 48 & 704 & 2 & & & \\
\hline $\begin{array}{l}\text { Magnet bore } \\
\text { diameter, m }\end{array}$ & 21.5 & & 28.3 & 12.1 & 11 & 0.95 & & & & \\
\hline
\end{tabular}


TABLE 2 (contd)

\begin{tabular}{|c|c|c|c|c|c|c|c|c|c|c|}
\hline $\begin{array}{l}\text { Magnetic Param- } \\
\text { eters (Contd) }\end{array}$ & UWMAK-I & $\begin{array}{l}\text { BNL } \\
\text { Blanket } \\
\end{array}$ & UWMAK-II & PPPL & ORHL & $\begin{array}{l}\text { Theta } \\
\text { Pinch }\end{array}$ & Mirror & Blascon & $\begin{array}{l}\text { Wet } \\
\text { Wall }\end{array}$ & $\begin{array}{l}\text { Suppressed } \\
\text { Ablation }\end{array}$ \\
\hline $\begin{array}{l}\text { Conductor } \\
\text { material }\end{array}$ & $\mathrm{NbTi}, \mathrm{Cu}$ & $\leftarrow$ & $\mathrm{NbTi}, \mathrm{Cu}$ & $\mathrm{Nb}_{3} \mathrm{Sn}, \mathrm{Cu}$ & $\mathrm{NbTi}, \mathrm{Cu}$ & $\mathrm{Cu}$ & $\begin{array}{l}\text { Unspecitied; } \\
\text { Cu }\end{array}$ & & & \\
\hline $\begin{array}{l}\text { Current density, } \\
\mathrm{kA} / \mathrm{cm}^{2}\end{array}$ & 1.3 & $\leftarrow$ & 2.2 & 2.2 & 4.8 & & 3.5 & & & \\
\hline $\begin{array}{l}\text { Max. magnetic } \\
\text { field, } T\end{array}$ & 8.7 & $\leftarrow$ & 8.3 & 16.0 & 5.3 & & 16.5 & & & \\
\hline $\begin{array}{l}\text { Magnetic field } \\
\text { at plasma } \\
\text { center, Telsa }\end{array}$ & 3.8 & $\leftarrow$ & 3.6 & 6.0 & 2.5 & $\begin{array}{l}11 \text { outside } \\
\text { plasma }\end{array}$ & 5.0 & & & \\
\hline $\begin{array}{l}\text { Auxiliary mag- } \\
\text { net systems }\end{array}$ & $\begin{array}{l}\text { Divertor and } \\
\text { vertical field; } \\
\text { transformer } \\
\text { field; energy } \\
\text { storage }\end{array}$ & $\leftarrow$ & $\begin{array}{l}\text { Divertor and } \\
\text { vertical field; } \\
\text { transtormer } \\
\text { field }\end{array}$ & $\begin{array}{l}\text { Vertical } \\
\text { field; divertor } \\
\text { field; control } \\
\text { (transformer) } \\
\text { field }\end{array}$ & $\begin{array}{l}\text { Poioidal } \\
\text { (vertical and } \\
\text { transformerl; } \\
\text { iron cores }\end{array}$ & $\begin{array}{l}\text { Implosion } \\
\text { heating; } \\
\text { energy } \\
\text { storage and } \\
\text { transfer }\end{array}$ & $\begin{array}{l}\text { Direct } \\
\text { convertor- } \\
\text { expander } \\
\text { field }\end{array}$ & & & \\
\hline $\begin{array}{l}\text { Stored magnetic } \\
\text { energy, } \\
\text { gigajoules }\end{array}$ & 240 & $\leftarrow$ & 232 & 255 & 40 & 63 & & & & \\
\hline $\begin{array}{l}\text { Plasma Heating } \\
\text { Parameters }\end{array}$ & UWMAK-I & $\begin{array}{l}\text { BNL } \\
\text { Blanket }\end{array}$ & UWMAK-II & PPPL & ORNL & $\begin{array}{l}\text { Theta } \\
\text { Pinch } \\
\end{array}$ & Mirror & Blascon & $\begin{array}{l}\text { Wet } \\
\text { Wall }\end{array}$ & $\begin{array}{l}\text { Suppressed } \\
\text { Ablation }\end{array}$ \\
\hline Method & $\begin{array}{l}\text { Plasma } \\
\text { current; } \\
\text { neutral } \\
\text { beams }\end{array}$ & $\leftarrow$ & $\begin{array}{l}\text { Plasma } \\
\text { current; } \\
\text { neutral } \\
\text { beams }\end{array}$ & $\begin{array}{l}\text { Plasma } \\
\text { current; } \\
\text { neutral } \\
\text { beams }\end{array}$ & $\begin{array}{l}\text { Plasma } \\
\text { current; } \\
\text { neutral } \\
\text { beams }\end{array}$ & $\begin{array}{l}\text { Magnetic } \\
\text { implosion; } \\
\text { magnetic } \\
\text { compression }\end{array}$ & $\begin{array}{l}\text { Neutral } \\
\text { beams }\end{array}$ & Laser & Laser & Laser \\
\hline $\begin{array}{l}\text { Neutral atom } \\
\text { beam power } \\
\text { MW }\end{array}$ & 15 & + & 200 & 8 & 10 & 0 & 490 & & & \\
\hline $\begin{array}{l}\text { Beam energy, } \\
\text { keV }\end{array}$ & 500 & $\leftarrow$ & 750 & 5 & 20 & & 550 & & & \\
\hline $\begin{array}{l}\text { Beam duration, } \\
\text { sec }\end{array}$ & 11 & + & 10 & 10 & Entire burn & & Continous & & & \\
\hline $\begin{array}{l}\text { Laser type and } \\
\text { number }\end{array}$ & & & & & & & & $\begin{array}{l}\text { Unspecified; } \\
1\end{array}$ & $\mathrm{CO}_{2} ; 8$ & Gas; 10 \\
\hline $\begin{array}{l}\text { Laser wave- } \\
\text { length, } \mu \mathrm{m}\end{array}$ & & & & & & & & & 10.6 & $0.3 \cdot 0.6$ \\
\hline $\begin{array}{l}\text { Laser beams } \\
\text { to pellets }\end{array}$ & & & & & & & & 1 & 8 & 12 \\
\hline $\begin{array}{l}\text { Laser energy } \\
\text { to pellet, MJ }\end{array}$ & & & & & & & & 1.0 & 1.0 & 0.1 \\
\hline $\begin{array}{l}\text { Laser pulse } \\
\text { rate, } \text { sec }^{-1}\end{array}$ & & & & & & & & 6 & 40 & 10 \\
\hline $\begin{array}{l}\text { Power recircu. } \\
\text { lated to lasers, } \\
\text { MW }\end{array}$ & & & & & & & & & 500 & 100 \\
\hline $\begin{array}{l}\text { Laser efficiency, } \\
\%\end{array}$ & & & & & & & & & 51 & 10 \\
\hline Pellet energy gain & & & & & & & & 800 & 100 & 70 \\
\hline
\end{tabular}


TABLE 2 (contd)

\begin{tabular}{|c|c|c|c|c|c|c|c|c|c|c|}
\hline $\begin{array}{l}\text { Fuel System } \\
\text { Parameters }\end{array}$ & UWMAK-I & $\begin{array}{l}\text { BNL } \\
\text { Blanket }\end{array}$ & UWMAK-II & PPPL & ORNL & $\begin{array}{l}\text { Theta } \\
\text { Pinch } \\
\end{array}$ & Mirror & Blascon & $\begin{array}{l}\text { Wet } \\
\text { Wall }\end{array}$ & $\begin{array}{l}\text { Suppressed } \\
\text { Ablation }\end{array}$ \\
\hline $\begin{array}{l}\text { Fueling } \\
\text { method }\end{array}$ & $\begin{array}{l}\text { Solid D-T } \\
\text { pellets }\end{array}$ & $\leftrightarrow$ & $\begin{array}{l}\text { Solid D-T } \\
\text { pellets }\end{array}$ & $\begin{array}{l}\text { Solid D-T } \\
\text { pellets }\end{array}$ & $\begin{array}{l}\text { Neutral } \\
\text { beam }\end{array}$ & Gas injection & Neutral beam & $\begin{array}{l}\text { Solid D.T } \\
\text { pellets with } \\
\text { Li mirror } \\
\text { assembly }\end{array}$ & $\begin{array}{l}\text { Solid D-T } \\
\text { pellets }\end{array}$ & $\begin{array}{l}\text { D-T hollow } \\
\text { spherical } \\
\text { peilets }\end{array}$ \\
\hline $\begin{array}{l}\text { Fuel feed rate, } \\
\mathrm{kg} / \text { day }\end{array}$ & $\begin{array}{l}\text { T.8.4; } \\
\text { D. } 5.6\end{array}$ & + & $\begin{array}{l}\text { T.12.9; } \\
\text { D-8.6 }\end{array}$ & $\begin{array}{l}\text { T-6.0; } \\
\text { D-4.0 }\end{array}$ & $\begin{array}{l}\text { T-0.6; } \\
\text { D. } 0.4\end{array}$ & $\begin{array}{l}\text { T-30.4; } \\
\text { D-20.2 }\end{array}$ & $\begin{array}{l}\text { T- } 0.9 \\
\text { D-1.0 }\end{array}$ & & $\begin{array}{l}\text { T-1.9; } \\
\text { D-1.3 }\end{array}$ & $\begin{array}{l}\text { T-0.52; } \\
\text { D-0.35 }\end{array}$ \\
\hline $\begin{array}{l}\text { Fuel consump- } \\
\text { tion, } \mathrm{kg} / \text { day }\end{array}$ & $\begin{array}{l}\text { T-0.69; } \\
\text { D. } 0.46\end{array}$ & $\leftarrow$ & $\begin{array}{l}\text { T- } 0.62 \\
\text { D- } 0.42\end{array}$ & $\begin{array}{l}\text { T-0.53; } \\
\text { D-0.35; } \\
\text { Li-1.1; } \\
\text { Be-0.36 }\end{array}$ & $\begin{array}{l}\text { T-0.12; } \\
\text { D. } 0.08\end{array}$ & $\begin{array}{l}\text { T-1.46; } \\
\text { D-0.97; } \\
\text { Li-3.36; } \\
\text { Be-1.75 }\end{array}$ & $\begin{array}{l}\text { T. } 0.080 \\
\text { D. } 0.053\end{array}$ & $\begin{array}{l}\text { T-0.6; } \\
\text { D. } 04\end{array}$ & $\begin{array}{l}\text { T- } 0.42 \\
\text { D- } 0.29\end{array}$ & $\begin{array}{l}\text { J.0.11; } \\
\text { D. } 0.073\end{array}$ \\
\hline $\begin{array}{l}\text { Fuel burnup, } \\
\%\end{array}$ & 7.2 & $\leftarrow$ & 4.9 & 8.7 & 20 & 4.8 & 6.7 & & 25 & 21 \\
\hline $\begin{array}{l}\text { Plasma } \\
\text { chamber fuel } \\
\text { charge, } \mathrm{g}\end{array}$ & $\mathrm{I}-1.3 ; \mathrm{D}-0.87$ & $\leftarrow$ & $\mathrm{T}-1.2 ; \mathrm{D}-0.78$ & $\begin{array}{l}\text { T. } 0.27 \\
\text { D. } 0.18\end{array}$ & $\begin{array}{l}T-0.72 \\
D-0.48\end{array}$ & $\begin{array}{l}\text { T- } 0.87 ; \\
0.0 .58\end{array}$ & $\begin{array}{l}T .0 .039 \\
D-0.026\end{array}$ & & $\begin{array}{l}\text { T- } 0.00078 \\
\text { D- } 0.00052\end{array}$ & $\begin{array}{l}\text { T. } 0.00006 \\
\text { D. } 0.00004\end{array}$ \\
\hline $\begin{array}{l}\text { He "ash" } \\
\text { production, } \\
\mathrm{kg} / \text { day }\end{array}$ & 0.92 & 4 & & 0.70 & 0.16 & 1.94 & 0.11 & & 0.58 & 0.15 \\
\hline $\begin{array}{l}\text { Fuel gas } \\
\text { purification }\end{array}$ & & & & $\begin{array}{l}\text { Cryogenic } \\
\text { distillation } \\
\text { prior to fuel } \\
\text { pellet mfg. }\end{array}$ & $\begin{array}{l}\text { Cryogenic } \\
\text { distillation }\end{array}$ & $\begin{array}{l}\text { Two stage } \\
\text { cryogenic } \\
\text { distillation }\end{array}$ & & & & \\
\hline $\begin{array}{l}\text { Fuel pellet } \\
\text { size, mm }\end{array}$ & & & & 1 & & & & & $\sim 1$ & 2 \\
\hline $\begin{array}{l}\text { Pellet velocity, } \\
\mathrm{m} / \mathrm{sec}\end{array}$ & $2 \times 10^{5}$ & & & $5 \times 10^{4}$ & & & & 100 & & 45 \\
\hline $\begin{array}{l}\text { Pellets per } \\
\text { day }\end{array}$ & & & & & & & & $5.2 \times 10^{5}$ & $2.5 \times 10^{6}$ & $8.4 \times 10^{6}$ \\
\hline $\begin{array}{l}\text { Blanket } \\
\text { Parameters; } \\
\text { Neutronic }\end{array}$ & UWMAK-1 & $\begin{array}{l}\text { BNL } \\
\text { Blanket }\end{array}$ & UWMAK-II & PPPL & ORNL & $\begin{array}{l}\text { Theta } \\
\text { Pinch } \\
\end{array}$ & Mirror & Blascon & $\begin{array}{l}\text { Wet } \\
\text { Wall }\end{array}$ & $\begin{array}{l}\text { Suppressed } \\
\text { Ablation }\end{array}$ \\
\hline $\begin{array}{l}\text { Neutron energy } \\
\text { deposition, } \\
\text { MeV per } \\
\text { fusion neutron } \\
\text { (w/o alpha } \\
\text { particle) }\end{array}$ & 16.6 & 15.7 & 18.1 & 23.5 & $18.9 ?$ & 20.5 & $15.5-17$ & & 19.0 & 15.9 \\
\hline \multicolumn{11}{|l|}{$\begin{array}{l}\text { Blanket inner } \\
\text { wall: }\end{array}$} \\
\hline $\begin{array}{l}\text { Neutron energy } \\
\text { loading, } \\
\mathrm{MW} / \mathrm{m}^{2}\end{array}$ & 1.25 & $\leftarrow$ & 1.16 & 1.76 & 0.43 & 6.7 & $\begin{array}{l}\text { avg. } 1.6 ; \\
1.9 \text { peak }\end{array}$ & . & 2.5 & 0.98 \\
\hline $\begin{array}{l}\text { Thermal energy } \\
\text { loading, } \\
\mathrm{MW} / \mathrm{m}^{2}\end{array}$ & 1.77 & 1.7 & 1.5 & 3.4 & 0.7 & 10.7 & $\sim 2$ & & 3.2 & 1.3 \\
\hline $\begin{array}{l}14 \mathrm{MeV} \text { neutron } \\
\text { current, } \\
\mathrm{n} / \mathrm{cm}^{2} \text {-sec }\end{array}$ & $5.5 \times 10^{13}$ & $\leftarrow$ & & $7.8 \times 10^{13}$ & $2 \times 10^{15}$ & $3 \times 10^{14}$ & $7.1 \times 10^{13}$ & & $1.2 \times 10^{14}$ & $3.9 \times 10^{! 3}$ \\
\hline
\end{tabular}


TABLE 2 (contd)

Blanket

Parameters;

Neutronic (Contd)
BNL

UWMAK-I Blanket UWMAK-II PPP
ORNL

Theta

Pinch
Mirror

Blascon

Wet

Wall

Suppressed Ablation

Blanket inner

wall (cont d)

Total flux,

$\mathrm{n} / \mathrm{cm}^{3} \cdot \mathrm{sec}$

Total fluence

at replacement

$\mathrm{n} / \mathrm{cm}^{2}$

Replacement interval, yr

Blanket

Parameters;

Materials

Inner wall

shield

material

Inner wall

materia!

Neutron

Moderator

Neutron

multiplying

material

Fertile

material

Structural

material

Neutron

reflector

material

Blanket

coolant

Neutron shield

material

Shield coolant

$4.7 \times 10^{14}$

$2.2 \times 10^{22} 2 \times 10^{22}$

2

3

2

$8.6 \times 10^{14}$

$1.5 \times 10^{14} \quad 2.7 \times 10^{15}$

$5.2 \times 10^{14}$

$1 \times 10^{23} \quad 3 \times 10^{12} \quad 1.7 \times 10^{23}$

$6.8 \times 10^{14} \quad 2.2 \times 10^{14}$

$2.5 \times 10^{22}$

1.7

BNL

UWMAK-1

Blank

UWMAK-II PPPL

Carbon PE-16 thin-

Cloth wall tubes)

ORNL

Pinch

Mirror

Blascon

Wall

Suppressed

Ablation

Lithium

Lithium

(liquid)

Type 316 SS $6061 \mathrm{Al}$

$163 \% \mathrm{Fe}$; Alloy Al

$18 \% \mathrm{Cr} ; \quad(+2 \% \mathrm{Mg}$

$14 \% \mathrm{Ni}+2 \% \mathrm{Si}$

Type 316 SS PE-16 (tubes) Niobium

(43\% Ni;

$37 \% \mathrm{Fe}$;

$18 \% \mathrm{Cr}$ )

Li metal Be, C, Li

Be, LiAlO, Li, Be (flibe) Li, C

microspheres $53 \% \mathrm{BeF}_{2}$

$47 \%$ LiF

$\mathrm{Be}$

$\mathrm{Be}$

Be (flibe)

$\mathrm{Al}_{2} \mathrm{O}_{3}$ on $\quad \mathrm{SS}$

Niobium

SS

Lithium

(liquid)

vortex

surface

Li, Be, C Li, C

Li, C Li metal

Niobium Niobium

(1)

Lirmetal

$\mathrm{Be}$

Li metal

LiAl, $\mathrm{LiAlO}_{2}$

Li flibe)

Li meta

Li, $6 \mathrm{Li}$,

Li Metal

(4\% $\left.{ }^{6} \mathrm{Li}\right)$

Type 316 SS Al $(+2 \% \mathrm{mg}$ Type 316 SS PE-16

Nb- $1 \% \mathrm{Zr} \quad$ NB- $1 \% \mathrm{Zr} \quad$ SS

Li metal

Li metal

$$
+2 \% \text { Sil }
$$

Type 316 SS

Graphite

Polyethylene

(liquid)

He (gas)

water

He (gas)

$\mathrm{He}$ (gas)

Li metal

(liquid)

Li metal

Li metal

(liquid)

Li metal
(liquid)

Li metal

(liquid)

$\mathrm{Pb}$; kerosene
$\mathrm{Pb} ; \mathrm{B}_{4} \mathrm{C} ; \mathrm{SS} \quad \mathrm{B}_{4} \mathrm{C} ; \mathrm{A}$

Pb; $B_{4} C ; S S$

$\mathrm{Fe}$; $\mathrm{B}$

He (gas)
He (gas)

C. $\mathrm{Pb} ; \mathrm{Ti}$

He (gas) - 
TABLE 2 (contd)

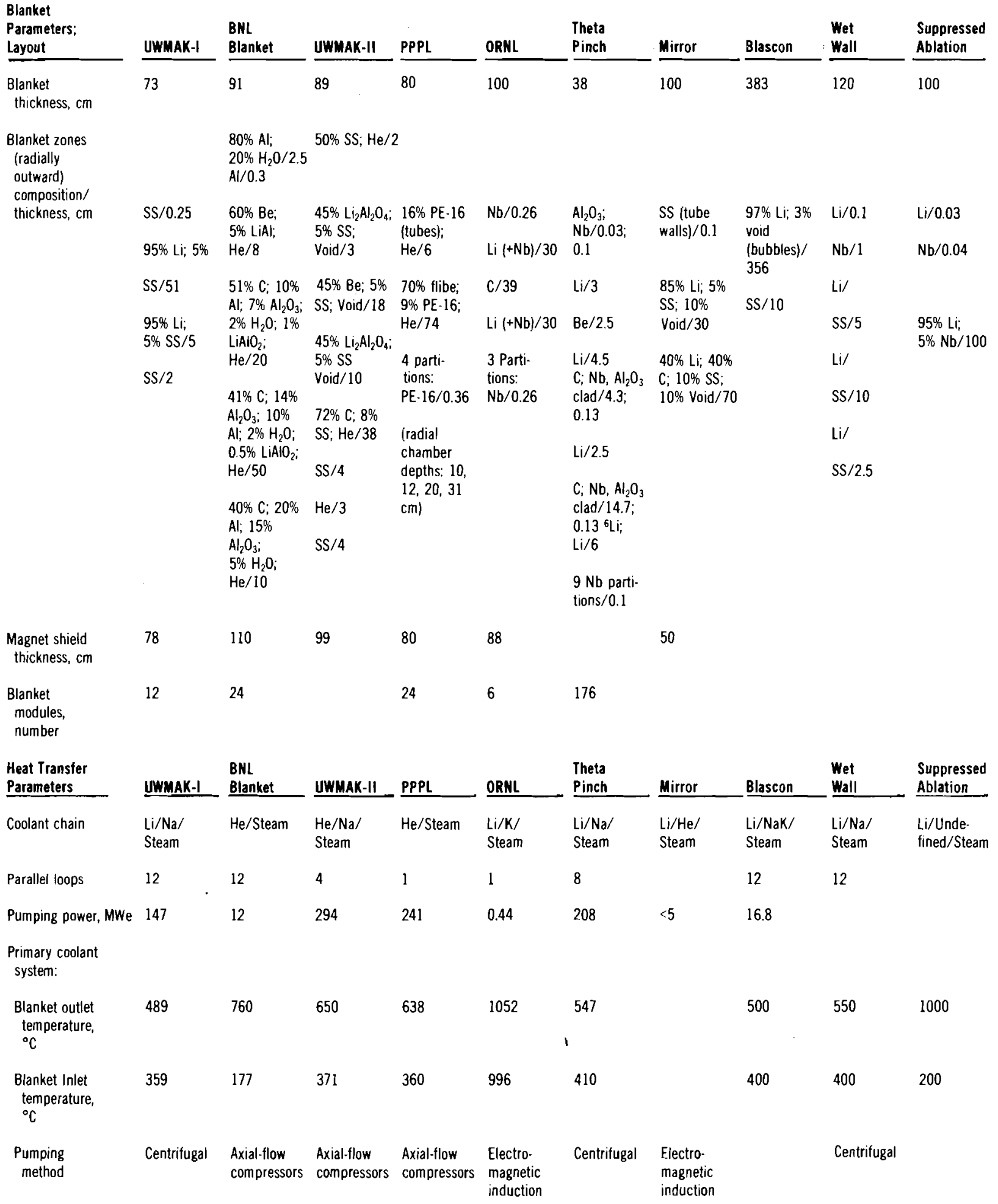


TABLE 2 (contd)

\begin{tabular}{|c|c|c|c|c|c|c|c|c|c|c|}
\hline $\begin{array}{l}\text { Hoat Transfor } \\
\text { Paramoters } \\
\text { (Contd) } \\
\end{array}$ & UWMAK-I & $\begin{array}{l}\text { BNL } \\
\text { Blanket }\end{array}$ & UWMAK-II & PPPL & ORNL & $\begin{array}{l}\text { Theta } \\
\text { Pinch }\end{array}$ & Mirror & Blascon & $\begin{array}{l}\text { Wet } \\
\text { Wall }\end{array}$ & $\begin{array}{l}\text { Suppressed } \\
\text { Ablation }\end{array}$ \\
\hline \multicolumn{11}{|l|}{$\begin{array}{l}\text { Primary coolant } \\
\text { system (contd): }\end{array}$} \\
\hline $\begin{array}{l}\text { Mass flow, } \\
\mathrm{kg} / \mathrm{hr}\end{array}$ & $3.2 \times 10^{7}$ & $4.1 \times 10^{6}$ & $1.5 \times 10^{\prime}$ & $1.2 \times 10^{7}$ & $3.2 \times 10^{\prime}$ & $8.2 \times 10^{7}$ & & $4.2 \times 10^{7}$ & $1.2 \times 10^{\prime}$ & $8.3 \times 10^{5}$ \\
\hline $\begin{array}{l}\text { Blanket inlet } \\
\text { pressure, } \\
\mathrm{kg} / \mathrm{cm}^{2}\end{array}$ & 47 & 21 & 52.8 & 52.6 & 0.1 & 3.3 & 7.0 & & & \\
\hline $\begin{array}{l}\text { Blanket } \\
\text { pressure drop, } \\
\mathrm{kg} / \mathrm{cm}^{2}\end{array}$ & 44 & 0.003 & 2 & 1.9 & 0.07 & 2.0 & & & & \\
\hline $\begin{array}{l}\text { Coolant mass, } \\
\text { kg }\end{array}$ & $1.7 \times 10^{6}$ & $9.1 \times 10^{3}$ & $4 \times 10^{3}$ & $4 \times 10^{4}$ & $4.6 \times 10^{5}$ & $8.6 \times 10^{5}$ & & $1.61 \times 10^{6}$ & & \\
\hline Piping material & 316 SS & & 316 SS & PE.16; SS & $\mathrm{Nb}$ & $\mathrm{Nb}$ & SS & SS & SS & \\
\hline \multicolumn{11}{|l|}{$\begin{array}{l}\text { Intermediate } \\
\text { heat } \\
\text { exchangers: }\end{array}$} \\
\hline Number & 12 & & 4 & & & 8 & & 12 & 12 & \\
\hline Type & $\begin{array}{l}\text { Shell and } \\
\text { tube }\end{array}$ & & $\begin{array}{l}\text { Shell and } \\
\text { tube }\end{array}$ & & $\begin{array}{l}K \text { boiler } \\
\text { tubes within } \\
\text { blanket }\end{array}$ & & & & & \\
\hline Material & 304 SS & & Incoloy & & $\mathrm{Nb}$ & $\mathrm{Nb} / 304 \mathrm{SS}$ & $\begin{array}{l}\mathrm{SS} ; \mathrm{Al}_{2} \mathrm{O}_{3} \\
\text { coated }\end{array}$ & SS & & \\
\hline $\begin{array}{l}\text { Total surface } \\
\text { area, } \mathrm{m}^{2}\end{array}$ & $1.9 \times 10^{4}$ & & $4.3 \times 10^{4}$ & & $1.8 \times 10^{3}$ & $3.7 \times 10^{4}$ & & $9.4 \times 10^{3}$ & & \\
\hline $\begin{array}{l}\text { Intermediate } \\
\text { coolant }\end{array}$ & $\mathrm{Na}$ & & $\mathrm{Na}$ & & k & $\mathrm{Na}$ & $\mathrm{He}$ & Nak & $\mathrm{Na}$ & Unspecified \\
\hline Outlet $\mathrm{I},{ }^{\circ} \mathrm{C}$ & 456 & & 567 & & 982 & 522 & & 470 & & \\
\hline Inlet $\mathrm{T},{ }^{\circ} \mathrm{C}$ & 336 & & 322 & & 927 & 352 & & 370 & & \\
\hline $\begin{array}{l}\text { Mass flow, } \\
\mathrm{kg} / \mathrm{hr}\end{array}$ & $1.2 \times 10^{B}$ & & $5.1 \times 10^{7}$ & & $1.8 \times 10^{6}$ & $2.0 \times 10^{8}$ & & & & \\
\hline $\begin{array}{l}\text { Inlet pressure, } \\
\mathrm{kg} / \mathrm{cm}^{2}\end{array}$ & 4.9 & & 2.5 & & 8.4 & 7.0 & & & & \\
\hline $\begin{array}{l}\text { Outlet } \\
\text { pressure, } \\
\mathrm{kg} / \mathrm{cm}^{2}\end{array}$ & 2.5 & & & & 5.8 & 6.2 & & & & \\
\hline $\begin{array}{l}\text { Coolant mass, } \\
\text { kg }\end{array}$ & $1.8 \times 10^{\prime}$ & & $8.4 \times 10^{6}$ & & $1.0 \times 10^{4}$ & & & & & \\
\hline Piping material & SS & & & & $\mathrm{Nb}$ & SS & & SS & & \\
\hline $\begin{array}{l}\text { Topping cycle } \\
\text { turbine }\end{array}$ & & & & & 1 & & & & & \\
\hline Inlet pressure & & & & & 5.8 & & & & & \\
\hline Outlet pressure & & & & & 0.2 & & & & & \\
\hline Outlet $\mathbf{I},{ }^{\circ} \mathrm{C}$ & & & & & 593 & & & & & \\
\hline
\end{tabular}


TABLE 2 (contd)

\begin{tabular}{|c|c|c|c|c|c|c|c|c|c|c|}
\hline $\begin{array}{l}\text { Heat Transfer } \\
\text { Parameters } \\
\text { (Contd) }\end{array}$ & UWMAK-1 & $\begin{array}{l}\text { BNL } \\
\text { Blanket } \\
\end{array}$ & UWMAK-II & PPPL & $\underline{\text { ORNL }}$ & $\begin{array}{l}\text { Theta } \\
\text { Pinch }\end{array}$ & Mirror & Blascon & $\begin{array}{l}\text { Wet } \\
\text { Wall } \\
\end{array}$ & $\begin{array}{l}\text { Suppressed } \\
\text { Ablation } \\
\end{array}$ \\
\hline $\begin{array}{l}\text { Steam } \\
\text { generator(s) }\end{array}$ & 12 & & 4 & 12 & 1 & 8 & & 12 & 12 & \\
\hline Type & $\begin{array}{l}\text { Double } \\
\text { reheat }\end{array}$ & $\begin{array}{l}\text { Superheat; } \\
\text { single } \\
\text { reheat }\end{array}$ & $\begin{array}{l}\text { Superheat: } \\
\text { single } \\
\text { resuperheat }\end{array}$ & $\begin{array}{l}\text { Super- } \\
\text { double } \\
\text { reheat }\end{array}$ & $\begin{array}{l}\text { Superheat: } \\
\text { double } \\
\text { reheat }\end{array}$ & & & & $\begin{array}{l}\text { LMFBR } \\
\text { technology }\end{array}$ & \\
\hline Material & $\begin{array}{l}\text { Croloy Mo } \\
\text { In } 60025 \\
\text { im He filled } \\
\text { gap }\end{array}$ & $\begin{array}{l}\text { T perme- } \\
\text { ation } \\
\text { Barrier regd. }\end{array}$ & $\begin{array}{l}\text { Croloy' } \\
321 \text { SS }\end{array}$ & Incoloy 800 & $\begin{array}{l}\mathrm{Nb} ; \\
\text { Tungsten } \\
\text { coaled }\end{array}$ & $\begin{array}{l}\text { Inco 800; } \\
\text { Cu sandwich }\end{array}$ & & SS & & \\
\hline $\begin{array}{l}\text { Total surface } \\
\text { area (inc. } \\
\text { reheat, if any) } \\
\mathrm{m}^{2}\end{array}$ & $3.7 \times 10^{=}$ & & $4.1 \times 10^{2}$ & $8.8 \times 10=$ & 3,000 & $4.0 \times 10^{4}$ & & $1.5 \times 10^{4}$ & & \\
\hline $\begin{array}{l}\text { Steam outiet } \mathrm{T} \text {. } \\
{ }^{\circ} \mathrm{C}\end{array}$ & 404 & 510 & 510 & 538 & 566 & 484 & & 450 & & \\
\hline $\begin{array}{l}\text { Outlet pressure, } \\
\mathrm{kg} / \mathrm{cm}\end{array}$ & 140 & 177 & 260 & 260 & 282 & 171 & & & & \\
\hline $\begin{array}{l}\text { Water Inlet } \mathrm{T} \text {. } \\
{ }^{\circ} \mathrm{C}\end{array}$ & 218 & & 232 & 294 & 316 & 260 & & & & \\
\hline $\begin{array}{l}\text { Inlet Pressure. } \\
\mathrm{kg} / \mathrm{cm}^{-}\end{array}$ & 148 & & 399 & & & 187 & & & & \\
\hline $\begin{array}{l}\text { Mass flow, } \\
\mathrm{kg} / \mathrm{hr}\end{array}$ & $7.5 \times 10$ & $3.9 \times 10^{0}$ & $6.2 \times 10^{5}$ & $6.6 \times 10^{6}$ & $1.5 \times 10^{6}$ & $2.1 \times 10^{7}$ & & & & \\
\hline $\begin{array}{l}\text { Electricity } \\
\text { Generation } \\
\text { Parameters }\end{array}$ & UWMAK-I & $\begin{array}{l}\text { BNL } \\
\text { Blanket } \\
\end{array}$ & UWMAK-II & PPPL & ORNL & $\begin{array}{l}\text { Theta } \\
\text { Pinch }\end{array}$ & Mirror & Blascon & $\begin{array}{l}\text { Wet } \\
\text { Wall } \\
\end{array}$ & $\begin{array}{l}\text { Suppressed } \\
\text { Abtation }\end{array}$ \\
\hline $\begin{array}{l}\text { Turbine- } \\
\text { generator } \\
\text { units }\end{array}$ & 2 & 1 & 2 & 2 & 2 & 4 & & & & \\
\hline Type & $\begin{array}{l}\text { Tandem } \\
\text { compound; } \\
1800 \mathrm{rpm} \text {; } \\
26 \mathrm{kV}\end{array}$ & $\begin{array}{l}\text { Tandem. } \\
\text { compound }\end{array}$ & $\begin{array}{l}\text { Cross- } \\
\text { compound: } \\
3600 / 1800 \\
\mathrm{rpm}\end{array}$ & $\begin{array}{l}\text { Cross- } \\
\text { compound; } \\
3600 \mathrm{rpm} \text {; } \\
26 \mathrm{kV}\end{array}$ & $\begin{array}{l}\text { Cross- } \\
\text { compound }\end{array}$ & $\begin{array}{l}\text { Jandem- } \\
\text { compound, } \\
\text { quadruple } \\
\text { flow; } 1800 \\
\text { rpm: } 22 \mathrm{kV}\end{array}$ & & & $\begin{array}{l}\text { Conven- } \\
\text { tional }\end{array}$ & $\begin{array}{l}\text { Conven- } \\
\text { tional }\end{array}$ \\
\hline $\begin{array}{l}\text { Net heat rate. } \\
\text { BTU } / k W-h r\end{array}$ & 9356 & 10670 & 9140 & 8917 & 6589 & 9912 & & & & \\
\hline $\begin{array}{l}\text { Condenser } \\
\text { pressure, psia }\end{array}$ & 1.7 & 1.2 & & 1.2 & 1.5 & 0.8 & & & & \\
\hline $\begin{array}{l}\text { Condenser } \\
\text { temperature. } \\
{ }^{\circ} \mathrm{C}\end{array}$ & 49 & $4 \hat{3}$ & 46 & 50 & 27 & 14 & . & & & \\
\hline $\begin{array}{l}\text { Waste heat } \\
\text { dissipation. MW }\end{array}$ & 3055 & 3395 & 3000 & 3141 & 431 & 8200 & 450 & & 2730 & 410 \\
\hline Method & $\begin{array}{l}\text { Mech. draft } \\
\text { wet cooling } \\
\text { towers }\end{array}$ & $\begin{array}{l}\text { Dry cooling } \\
\text { towers }\end{array}$ & $\begin{array}{l}\text { Hypertolic } \\
\text { cooling } \\
\text { tower }\end{array}$ & $\begin{array}{l}\text { Wet-dry } \\
\text { cooling } \\
\text { towers }\end{array}$ & & & & & $\begin{array}{l}\text { Nat'l draft } \\
\text { cooling } \\
\text { towers }\end{array}$ & \\
\hline
\end{tabular}


TABLE 2 (contd)

\begin{tabular}{|c|c|c|c|c|c|c|c|c|c|c|}
\hline $\begin{array}{l}\text { Electricity } \\
\text { Generation } \\
\text { Parameters (Contd) } \\
\end{array}$ & UWMAK-I & $\begin{array}{l}\text { BNL } \\
\text { Blanket } \\
\end{array}$ & UWMAK-II & PPPL & ORNL & $\begin{array}{l}\text { Theta } \\
\text { Pinch }\end{array}$ & Mirror & Blascon & $\begin{array}{l}\text { Wet } \\
\text { Wall }\end{array}$ & $\begin{array}{l}\text { Suppressed } \\
\text { Ablation } \\
\end{array}$ \\
\hline $\begin{array}{l}\text { Secondary } \\
\text { cooling } \\
\text { system }\end{array}$ & $\begin{array}{l}\text { Radiation } \\
\text { shield } \mathrm{He} \\
200^{\circ} \mathrm{C} \text { max } \\
50 \mathrm{MWI}\end{array}$ & $\begin{array}{l}\text { First wall } \\
\text { cooling } \\
\text { [water/ } \\
\text { steam) gets } \\
32 \% \text { of } \\
\text { energy at } \\
204^{\circ} \mathrm{C} \text {, } \\
750 \text { psia; } \\
\text { superheated } \\
\text { by He } \\
\text { coolant for } \\
\text { separate } \\
\text { turbine }\end{array}$ & $\begin{array}{l}\text { Radiation } \\
\text { shield } \mathrm{He} \\
200^{\circ} \mathrm{C} \text { max, } \\
50 \mathrm{MWt}\end{array}$ & $\begin{array}{l}\text { Radiaiton } \\
\text { shield } \\
\mathrm{He}\left(95^{\circ} \mathrm{C}\right. \\
\text { max) feeds } \\
\text { to first wall } \\
\text { shield then } \\
\text { to middle } \\
\text { blanket }\end{array}$ & $\begin{array}{l}\text { Radiation } \\
\text { shield } \\
\text { cooling; } \\
\mathrm{He}, 100^{\circ} \mathrm{C}\end{array}$ & $\begin{array}{l}\text { Biological } \\
\text { shield } \\
\text { coolant }\end{array}$ & & & $\begin{array}{l}\text { Laser } \\
\text { amplifier } \\
413 \mathrm{MW}\end{array}$ & $\begin{array}{l}\text { Laser system } \\
\text { system } \\
60 \mathrm{MW}\end{array}$ \\
\hline $\begin{array}{l}\text { Emergency } \\
\text { cooling } \\
\text { system }\end{array}$ & & & & & $\begin{array}{l}\text { Thermal } \\
\text { radiation } \\
\text { to shield } \\
\text { cooling }\end{array}$ & & & & & \\
\hline $\begin{array}{l}\text { Spent Plasma } \\
\text { Collection } \\
\text { Parameters }\end{array}$ & UWMAK-I & $\begin{array}{l}\text { BNL } \\
\text { Blanket }\end{array}$ & UWMAK-II & PPPL & ORHL & $\begin{array}{l}\text { Theta } \\
\text { Pinch }\end{array}$ & Mirror & Blascon & $\begin{array}{l}\text { Wet } \\
\text { Wall }\end{array}$ & $\begin{array}{l}\text { Suppressed } \\
\text { Ablation- }\end{array}$ \\
\hline $\begin{array}{l}\text { Collection } \\
\text { methods }\end{array}$ & $\begin{array}{l}\text { Divertor: } \\
\text { entrainment } \\
\text { in liquid } \mathrm{Li} \text {, } \\
\text { and vacuum } \\
\text { pumping }\end{array}$ & $\begin{array}{l}\text { Divertor: } \\
\text { cyropumping }\end{array}$ & $\begin{array}{l}\text { Divertor: } \\
\text { entrainment } \\
\text { in liquid } \mathrm{Li} \text {, } \\
\text { and vacuum } \\
\text { pumping }\end{array}$ & $\begin{array}{l}\text { Divertor: } \\
\text { vacuum } \\
\text { pumping of } \\
\text { deionized } \\
\text { plasma }\end{array}$ & $\begin{array}{l}\text { Vacuum } \\
\text { pumping } \\
\text { between } \\
\text { burn cycles }\end{array}$ & $\begin{array}{l}\text { Purge and } \\
\text { pump down } \\
\text { between } \\
\text { burn cycles }\end{array}$ & $\begin{array}{l}\text { Direct Con- } \\
\text { vertor: } \\
\text { continuous } \\
\text { vacuum } \\
\text { pumping of } \\
\text { neutralized } \\
\text { ions }\end{array}$ & $\begin{array}{l}\text { Entrainment } \\
\text { in liquid } L i \text {, } \\
\text { and vacuum } \\
\text { pumping } \\
\text { between } \\
\text { pulses }\end{array}$ & $\begin{array}{l}\text { Entrainment } \\
\text { in Li blow. } \\
\text { down, and } \\
\text { vacuum } \\
\text { pumping } \\
\text { between } \\
\text { pulses }\end{array}$ & $\begin{array}{l}\text { Vacuum } \\
\text { pumping } \\
\text { between } \\
\text { pulses, and } \\
\text { entrainment } \\
\text { in liquid } \mathrm{Li}\end{array}$ \\
\hline $\begin{array}{l}\text { Plasma chamber } \\
\text { vacuum, Torr }\end{array}$ & $1 \times 10^{-5}$ & & $10^{-4}$ & $4.5 \times 10^{-4}$ & $1 \times 10^{-3}$ & $4.6 \times 10^{-2}$ & $2 \times 10^{-5}$ & $<10$ & & \\
\hline $\begin{array}{l}\text { Vacuum pumping } \\
\text { speed, liters/ } \\
\text { sec }\end{array}$ & $2.6 \times 10^{6}$ & Undefined & $7.5 \times 10^{6}$ & $6.7 \times 10^{5}$ & $5 \times 10^{4}$ & $2.3 \times 10^{6}$ & $5.6 \times 10^{7}$ & & $2 \times 10^{4}$ & $3 \times 10^{5}$ \\
\hline $\begin{array}{l}\text { High vacuum } \\
\text { pumps; type/ } \\
\text { number }\end{array}$ & $\begin{array}{l}\text { Diffusion } \\
(\mathrm{Hg}) / 96 \\
\text { cryopumps/ } \\
192\end{array}$ & & $\begin{array}{l}\text { Cryopumps/ } \\
96\end{array}$ & $\begin{array}{l}\text { Diffusion } \\
(\mathrm{Hg}) / 96\end{array}$ & $\begin{array}{l}\text { Turbo- } \\
\text { molecular }\end{array}$ & $\begin{array}{l}\text { Roots } \\
\text { blowers } / 352\end{array}$ & $\begin{array}{l}\text { Diffusion/ } \\
400\end{array}$ & & & \\
\hline Backing pumps & Roots blowers & & & $\begin{array}{l}\mathrm{Hg} \text { ejector } \\
\text { pumps }\end{array}$ & & & & & & \\
\hline $\begin{array}{l}\text { Pumping power, } \\
\text { MWe }\end{array}$ & 3 & & & & & 12.3 & 14 & & & 1.4 \\
\hline $\begin{array}{l}\text { Bred Tritium } \\
\text { Recovery } \\
\text { Parameters }\end{array}$ & UWMAK-I & $\begin{array}{l}\text { BNL } \\
\text { Blanket }\end{array}$ & _ UWMAK-II & PPPL & ORNL & $\begin{array}{l}\text { Theta } \\
\text { Pinch }\end{array}$ & Mirror & Blascon & $\begin{array}{l}\text { Wet } \\
\text { - Wall }\end{array}$ & $\begin{array}{l}\text { Suppressed } \\
\text { Ablation } \\
\end{array}$ \\
\hline Breeding ratio & 1.49 & 1.2 & 1.1 & 1.04 & $1.3 \cdot 1.4$ & 1.11 & $1.0 \cdot 1.2$ & 1.3 & 1.2 & 1.49 \\
\hline $\begin{array}{l}\text { Amount bred; } \\
\mathrm{kg} / \text { day }\end{array}$ & 1.03 & 0.83 & 0.68 & 0.55 & 0.16 & 1.6 & 0.09 & 0.8 & 0.5 & 0.16 \\
\hline $\begin{array}{l}\text { Doubling time, } \\
\text { months }\end{array}$ & $2-3$ & $2 \cdot 3$ & & 4 & & 1.3 & & & & \\
\hline
\end{tabular}


TABLE 2 (contd)

\begin{tabular}{|c|c|c|c|c|c|c|c|c|c|c|}
\hline $\begin{array}{l}\text { Bred Tritium } \\
\text { Recovery Param- } \\
\text { eters (Contd) } \\
\end{array}$ & UWMAK-I & $\begin{array}{l}\text { BNL } \\
\text { Blanket }\end{array}$ & UWMAK-II & PPPL & ORNL & $\begin{array}{l}\text { Theta } \\
\text { Pinch }\end{array}$ & Mirror & Blascon & $\begin{array}{l}\text { Wet } \\
\text { Wall }\end{array}$ & $\begin{array}{l}\text { Suppressed } \\
\text { Ablation }\end{array}$ \\
\hline $\begin{array}{l}\text { Method of } \\
\text { recovery from } \\
\text { blanket }\end{array}$ & $\begin{array}{l}\text { Gettering } \\
\text { from } L i ; \\
\text { offgassing }\end{array}$ & $\begin{array}{l}\text { Diffusion } \\
\text { from fertile } \\
\text { particles } \\
\text { into } \mathrm{He} \text {; } \\
\text { gettering; } \\
\text { offgassing }\end{array}$ & $\begin{array}{l}\text { Diffusion } \\
\text { from LiAlO } \\
\text { powder into } \\
\text { collection } \\
\text { plenna }\end{array}$ & $\begin{array}{l}\text { If evolution } \\
\text { from flibe } \\
\text { spray; cold } \\
\text { trapping; } \\
\text { electrolysis }\end{array}$ & $\begin{array}{l}\text { Permeation } \\
\text { from Li } \\
\text { through Nb } \\
\text { walls to } \\
\text { vacuum } \\
\text { system }\end{array}$ & $\begin{array}{l}\text { Li/molten } \\
\text { salt contact; } \\
\text { centrif- } \\
\text { ugation; } \\
\text { electro- } \\
\text { chemical } \\
\text { separation } \\
\text { from salt }\end{array}$ & $\begin{array}{l}\text { Permeation } \\
\text { from Li } \\
\text { through SS } \\
\text { tubes to } \\
\text { vacuum } \\
\text { system }\end{array}$ & $\begin{array}{l}\text { Permeation } \\
\text { from Li to } \\
\text { NaK coolant; } \\
\text { gettering; } \\
\text { cold } \\
\text { trapping }\end{array}$ & $\begin{array}{l}\text { Cold trap- } \\
\text { ping LiT and } \\
\text { diffusion } \\
\text { through } \\
\text { membranes }\end{array}$ & Undefined \\
\hline $\begin{array}{l}\text { Residual } \\
\text { concentration, } \\
\text { ppm }\end{array}$ & 5 & & 1.5 & 0.2 & $\sim 1$ & 0.5 & & & & \\
\hline $\begin{array}{l}\text { Recovery agent/ } \\
T^{\circ} \mathrm{C}\end{array}$ & $Y / 238$ & $\mathrm{Ti} / 500$ & $\mathrm{O}_{2}$ in $\mathrm{He}$ & Flibe/ 660 & & LiCl-KCl/410 & & $\mathrm{Li} / 350$ & & \\
\hline Agent quantity & $1670 \mathrm{~kg}$ & & & & & & & & & \\
\hline $\begin{array}{l}\text { System flows: } \\
\text { material/(kg/hr) }\end{array}$ & $\mathrm{Li} / 3.2 \times 10^{6}$ & $\mathrm{He} / 2.1 \times 10^{5}$ & & Flibe $/ 4 \times 10^{6}$ & & & & & & \\
\hline $\begin{array}{l}\text { System power } \\
\text { MW }\end{array}$ & & & & 0.4 & & 3.3 & & & & \\
\hline $\begin{array}{l}\text { Tritium } \\
\text { Inventory } \\
\text { Parameters }\end{array}$ & UWMAK-I & $\begin{array}{l}\text { BNL } \\
\text { Blanket }\end{array}$ & UWMAK-II & PPPL & ORNL & $\begin{array}{l}\text { Theta } \\
\text { Pinch }\end{array}$ & Mirror & Blascon & $\begin{array}{l}\text { Wet } \\
\text { Wall } \\
\end{array}$ & $\begin{array}{l}\text { Suppressed } \\
\text { Ablation } \\
\end{array}$ \\
\hline $\begin{array}{l}\text { Total plant } \\
\text { inventory, } \mathrm{kg}\end{array}$ & 23.5 & 10.1 & 17.5 & 2.58 & 5.7 & 3.8 & & & & \\
\hline $\begin{array}{l}\text { Total active } \\
\text { inventory, } \mathrm{kg}\end{array}$ & 13.5 & 0.13 & 4.6 & 0.56 & 0.14 & 2.4 & & & & \\
\hline Btanket & & 0.014 & 0.4 & 0.01 & & & & & & \\
\hline Coolant & 8.7 & 0.001 & 0.2 & 0.01 & 0.12 & 0.35 & & & & \\
\hline Structure & & & & 0.03 & 0.02 & & & & & \\
\hline Gettering system & 4.5 & 0.007 & 3.9 & & & 0.38 & & & & \\
\hline Fuel system & & 0.107 & & 0.51 & & 1.64 & & & & \\
\hline Cryopumps & 0.3 & & 0.1 & & & & & & & \\
\hline Storage, $\mathrm{kg}$ & 10.0 & 10.0 & 12.9 & 2.02 & 5.6 & 1.43 & & & & \\
\hline $\begin{array}{l}\text { Storage, multiples } \\
\text { of daily injection }\end{array}$ & 1.2 & 1.2 & 1.0 & 0.33 & 9.3 & 0.05 & & & & \\
\hline $\begin{array}{l}\text { Storage, multiples } \\
\text { of daily con- } \\
\text { sumption }\end{array}$ & 14.5 & 14.5 & 21 & 3.8 & 47 & 1.0 & & & & \\
\hline
\end{tabular}


TABLE 2 (contd)

\begin{tabular}{|c|c|c|c|c|c|c|c|c|c|c|}
\hline $\begin{array}{l}\text { Waste } \\
\text { Production }\end{array}$ & UWMAK-I & $\begin{array}{l}\text { BNL } \\
\text { Blanket } \\
\end{array}$ & UWMAK-II & PPPL & ORNL & $\begin{array}{l}\text { Theta } \\
\text { Pinch }\end{array}$ & Mirror & Blascon & $\begin{array}{l}\text { Wet } \\
\text { Wall } \\
\end{array}$ & $\begin{array}{l}\text { Suppressed } \\
\text { Ablation }\end{array}$ \\
\hline Waste source & $\begin{array}{l}\text { Blanket; } \\
\text { inner } 20 \mathrm{~cm} \\
\text { (2 yr life) }\end{array}$ & $\begin{array}{l}\text { Blanket; } \\
\text { full depth } \\
\text { (3 yr life) }\end{array}$ & $\begin{array}{l}\text { Blanket; } \\
\text { inner } 20 \mathrm{~cm} \\
\text { (2 yr life) }\end{array}$ & $\begin{array}{l}\text { Blanket; } \\
\text { full depth } \\
\text { (5 yr life) }\end{array}$ & $\begin{array}{l}\text { Blanket; } \\
\text { full depth } \\
\text { (10 yr life) }\end{array}$ & $\begin{array}{l}\text { Blanket: } \\
\text { full depth } \\
\text { (5 yr life) }\end{array}$ & $\begin{array}{l}\text { Blanket; } \\
\text { inner } 30 \mathrm{~cm} \\
(2 \mathrm{yr} \text { life })\end{array}$ & & $\begin{array}{l}\text { Blanket; } \\
\text { (1.7 yr life) }\end{array}$ & \\
\hline $\begin{array}{l}\text { Avg. waste per yr; } \\
\text { material/tonnes }\end{array}$ & $S S / 230$ & $\begin{array}{l}\mathrm{Al} / 230 \\
\mathrm{C} / 170 \\
\mathrm{Al}_{2} \mathrm{O}_{3} / 43 \\
\mathrm{LiA} / \mathrm{O}_{2} / 4 \\
\mathrm{Be} / 1\end{array}$ & $\begin{array}{l}\mathrm{SS} / 690 \\
\mathrm{LiAlO} / 210 \\
\mathrm{Be} / 18\end{array}$ & PE-16/220 & $\begin{array}{l}\mathrm{Nb} / 14 \\
\mathrm{C} / 110\end{array}$ & $\begin{array}{l}\mathrm{Nb} / 77 \\
\mathrm{C} / 140 \mathrm{Be} / 10\end{array}$ & $S S / 19$ & & $S S / 90$ & \\
\hline Waste source & $\begin{array}{l}\text { Blanket; } \\
\text { outer } 53 \mathrm{~cm} \\
\text { (10 yr life) }\end{array}$ & & $\begin{array}{l}\text { Blanket; } \\
\text { outer } 69 \mathrm{~cm} \\
\text { (10 yr life) }\end{array}$ & $\begin{array}{l}\text { Corrosion } \\
\text { product } \\
\text { cleanup }\end{array}$ & $\begin{array}{l}\text { Fuel purifi- } \\
\text { cation }\left({ }^{\prime} H\right)\end{array}$ & $\begin{array}{l}\text { Cold trap } \\
\text { (corrosion } \\
\text { prod?] }\end{array}$ & $\begin{array}{l}\text { Blanket; } \\
\text { outer } 70 \mathrm{~cm} \\
\text { (10 yr life) }\end{array}$ & & & \\
\hline $\begin{array}{l}\text { Avg. waste per yr; } \\
\text { material/tonnes }\end{array}$ & $S S / 490$ & & $\begin{array}{l}S S / 150 \\
\mathrm{C} / 80\end{array}$ & $\begin{array}{l}\text { Cr Com- } \\
\text { pounds/12 } \\
\text { Ni \& Fe Com- } \\
\text { pounds } / 1\end{array}$ & $\mathrm{CaOH} / 1$ & $? / 2$ & $\begin{array}{l}S S / 14 \\
C / 11\end{array}$ & & & \\
\hline Waste source & $\begin{array}{l}\text { Corrosion } \\
\text { product } \\
\text { cleanup }\end{array}$ & & & & & & & & & \\
\hline $\begin{array}{l}\text { Avg. waste per yr; } \\
\text { material/tonnes }\end{array}$ & $\begin{array}{l}\text { SS com- } \\
\text { pounds } / 2.8\end{array}$ & & & & & & & & & \\
\hline $\begin{array}{l}\text { Total avg. waste } \\
\text { per yr per GWe, } \\
\text { material/tonnes }\end{array}$ & $\begin{array}{l}\text { SS } / 490 \\
\text { corr. } / 1.9\end{array}$ & $\begin{array}{l}\mathrm{Al} / 144 \\
\mathrm{C} / 110 \\
\mathrm{Al}_{2} \mathrm{O}_{3} / 27 \\
\mathrm{LiAlO} \mathrm{O}_{2} / 2.5 \\
\mathrm{Be} / 0.6\end{array}$ & $\begin{array}{l}\mathrm{SS} / 490 \\
\mathrm{LiAlO} / 125 \\
\mathrm{Be} / 10 \mathrm{C} / 50\end{array}$ & $\begin{array}{l}\text { PE-16/110 } \\
\text { corr. } / 6.2\end{array}$ & $\begin{array}{l}\mathrm{Nb} / 27 \\
\mathrm{C} / 212\end{array}$ & $\begin{array}{l}\mathrm{Nb} / 19 \\
\mathrm{C} / 34 \\
\mathrm{Be} / 2.4 \\
\text { corr. } / 0.5\end{array}$ & $\begin{array}{l}S S / 192 \\
\mathrm{C} / 66\end{array}$ & & $\mathrm{SS} / 90$ & \\
\hline $\begin{array}{l}\text { Activity/after- } \\
\text { heat of annual } \\
\text { waste quantity; } \\
\text { (MCi]/[MW] }\end{array}$ & & & $\begin{array}{l}\text { Similar to } \\
\text { UWMAK-I }\end{array}$ & & & & & & & \\
\hline At shutdown & $1000 / 10$ & $700 /$ & & $4000 /$ & $70 / 0.25$ & $12000 / 180$ & & & & \\
\hline After brief decay & & $7 /$ & & $2000 / 10$ & & & & & & \\
\hline After $1 \mathrm{yr}$ & $350 / 1$ & & & $300 / 0.6$ & & $200 / 0.2$ & & & & \\
\hline $\begin{array}{l}\text { After N yrs: } \\
N(M C,(M) /(M W)\end{array}$ & $20: 5 / 0.01$ & $10: 0.0003 /$ & & $20: 10 /$ & & $20: 50 /$ & & & & \\
\hline \multicolumn{11}{|l|}{$\begin{array}{l}\text { Major sources of } \\
\text { long-lived } \\
\text { radioactivity: }\end{array}$} \\
\hline Material & SS structure & $\begin{array}{l}\text { Structural } \\
\text { impurities } \\
\text { and } \mathrm{Al}\end{array}$ & & $\begin{array}{l}\text { PE-16 } \\
\text { structure }\end{array}$ & Nb structure & $\begin{array}{l}\text { Nb structure } \\
\text { Cu coils }\end{array}$ & & & & \\
\hline Isotopes/T 1/2 yrs) & $\begin{array}{l}{ }^{55} \mathrm{Fe} / 2.7 \\
{ }^{54} \mathrm{Mn} / 0.9 \\
{ }^{57} \mathrm{Co} / 0.7 \\
60 \mathrm{Co} / 5.3 \\
{ }^{49} \mathrm{~V} / 0.9 \\
{ }^{63} \mathrm{Ni} / 100\end{array}$ & $\begin{array}{l}{ }^{54} \mathrm{Mn} / 0.9 \\
119 \mathrm{~m} / \mathrm{Sn} / 0.7 \\
{ }^{55} \mathrm{Fe} / 2.7 \\
{ }^{65} \mathrm{Zn} / 0.7 \\
{ }^{26} \mathrm{Al} / 7 \times 10^{5}\end{array}$ & & $\begin{array}{l}{ }^{57} \mathrm{Co} / 0.7 \\
{ }^{55} \mathrm{Fe} / 2.7 \\
{ }^{60} \mathrm{Co} / 5.3 \\
{ }^{54} \mathrm{Mn} / 0.9 \\
{ }^{49} \mathrm{Ni} / 100 \\
{ }^{49} \mathrm{~V} / 0.9\end{array}$ & $\begin{array}{l}{ }_{93} \mathrm{~m}_{\mathrm{Nb}} / 14 \\
{ }^{94} \mathrm{Nb} / 2 \times 10^{4}\end{array}$ & $\begin{array}{l}{ }^{93 \mathrm{~m}} \mathrm{Nb} / 14 \\
{ }^{60} \mathrm{C} / 5.3 \\
{ }^{63} \mathrm{Ni} / 100 \\
{ }^{94} \mathrm{Nb} / 2 \times 10^{4}\end{array}$ & & & & \\
\hline
\end{tabular}


TABLE 3 Fusion Power. Plant Material Requirements for Construction (metric tons)

\begin{tabular}{|c|c|c|c|c|c|c|c|}
\hline Element & $\begin{array}{l}\text { UWMAK-I (a) } \\
\text { Total } \\
\end{array}$ & $\begin{array}{l}\text { BNL Blanket (b) } \\
\text { Blanket and } \\
\text { Shield } \\
\end{array}$ & $\begin{array}{l}\text { UWMAK-II } \\
\text { Total } \\
\end{array}$ & $\begin{array}{l}\text { PPPL }(c) \\
\text { Total } \\
\end{array}$ & $\begin{array}{c}\operatorname{ORNL}^{(\mathrm{d})} \\
\text { Nuclear Is land } \\
\end{array}$ & $\begin{array}{l}\text { Theta } \\
\text { Pinch (e) } \\
\text { Total } \\
\end{array}$ & $\begin{array}{l}\text { Mirror }(f) \\
\text { Reactor and } \\
\text { Convertor } \\
\end{array}$ \\
\hline Al & 792 & 2,488 & 2,292 & 17 & & & \\
\hline B & 1,580 & 5,790 & 4,280 & & & & \\
\hline $\mathrm{Be}$ & & 189 & 733 & 875 & & 50 & \\
\hline C & 446 & 3,138 & 4,890 & & 1,100 & 680 & 233 \\
\hline $\mathrm{Cr}$ & 11,689 & & 4,897 & 1,658 & 36 & & 7,506 \\
\hline $\mathrm{Cu}$ & 10,725 & & 11,116 & 3,264 & 450 & 9,300 & 8,810 \\
\hline $\mathrm{Fe}$ & 114,796 & & 92,141 & 11,921 & 6,424 & & 24,770 \\
\hline $\mathrm{He}$ & 138 & & 91 & 117 & 1 & 1,200 & \\
\hline $\mathrm{Hg}$ & 3 & & & & 10 & & \\
\hline \multicolumn{8}{|l|}{ K } \\
\hline $\mathrm{Li}$ & 1,700 & 60 & 350 & 598 & 460 & 1,600 & 83 \\
\hline Mn & 1,215 & & 788 & 164 & & & 751 \\
\hline Mo & 601 & & 505 & 288 & & & \\
\hline $\mathrm{Na}$ & 17,826 & & 9,816 & & & & \\
\hline $\mathrm{Nb}$ & 140 & & 153 & 102 & 1,000 & 3,600 & \\
\hline $\mathrm{Ni}$ & 8,705 & & 5,435 & 1,647 & 28 & & 4,504 \\
\hline $\mathrm{Pb}$ & 20,500 & & 19,800 & & 5,350 & & 1,272 \\
\hline Sn & & & & 34 & & 300 & \\
\hline $\mathrm{Ti}$ & 72 & & 105 & 17 & 642 & & \\
\hline$Y$ & 5 & & 3 & & & & \\
\hline $\mathrm{Zr}$ & 100 & & & 1 & 1 & & \\
\hline Concrete & 680,000 & & 680,000 & 32,000 & 20,000 & & 38,200 \\
\hline
\end{tabular}

a. Not including turbine, cooling towers, switch gear. Differs from design document-replacement quantities subtracted.

b. Blanket and shield major components only. Feedstock for ${ }^{6} \mathrm{Li}$ enrichment included.

c. Reactor building contents (major components) only.

d. Nuclear Is land major components only.

e. Major plant components only. Buildings not included. Feedstock for ${ }^{6} \mathrm{Li}$ enrichment included.

f. Reactor optimized for small size, not minimal material usage. Requirements estimated from description. 
TABLE 4 Fusion Power Plant Material Requirements for Operation. Average annual replacement quantities (metric tons).

\begin{tabular}{|c|c|c|c|c|c|c|c|}
\hline Element & $\underline{\text { UWMAK-I }}{ }^{(\mathrm{a})}$ & $\begin{array}{c}\mathrm{BNL} \\
\text { Blanket (b) } \\
\end{array}$ & UWMAK-II $(\mathrm{c})$ & $\mathrm{PPPL}^{(\mathrm{d})}$ & $\mathrm{ORNL}^{(\mathrm{e})}$ & Theta Pinch (f) & Mirror $(\mathrm{g})$ \\
\hline Al & 7.2 & 252 & 83 & & & & \\
\hline $\mathrm{Be}$ & & 1 & 18 & & & 10 & \\
\hline$c$ & & 174 & & & 110 & 140 & 11. \\
\hline $\mathrm{Cr}$ & 129. & & 151 & 39 & & & 6.3 \\
\hline $\mathrm{Cu}$ & 7.2 & & 8.4 & & & 2 & \\
\hline $\mathrm{Fe}$ & 445. & & 521 & 85 & & & 20 . \\
\hline $\mathrm{He}$ & & & & & & 1 & \\
\hline $\mathrm{Li}$ & & 5 & 21 & & & 16 & \\
\hline$M n$ & 14. & & 17 & & & & 0.6 \\
\hline Mo & 14. & & 17 & & & & \\
\hline $\mathrm{Nb}$ & & & & & 14 & 77 & \\
\hline $\mathrm{Ni}$ & 100 & & 118 & 94 & & & 3.8 \\
\hline $\mathrm{Zr}$ & & & & & 0.1 & & \\
\hline
\end{tabular}

a. Due to 316 SS replacement. $32 \%$ due to replacement of inner blanket every 2 years; $68 \%$ due to replacement of remainder of blanket every 10 years.

b. Replace one-third of blanket modules each year.

c. Stainless steel replacement: $82 \%$ due to inner blanket replacement every 2 years; $18 \%$ due to replacement of remainder of blanket every 10 years.

d. Due to $\mathrm{Pe}-16$ replacement; one-fifth of blanket each year.

e. Replace blanket every 10 years.

f. Replace one-fifth of blanket modules each year.

g. Blanket life is not estimated in the design. 304 SS structure and first wall loading are similar to UWMAK-I. Table is based upon replacement schedule postulated by rough analogy to UWMAK-I. Replacement of inner $30 \mathrm{~cm}$ of blanket every 2 years; replacement of outer $70 \mathrm{~cm}$ of blanket every 10 years; 30 year plant 1 ife. 
TABLE 5 Normalized Fusion Power Plant Design Parameters, Per 1000 MWe Net Output

\begin{tabular}{|c|c|c|c|c|c|c|c|c|c|c|}
\hline Parameters & UWMAK-I & $\begin{array}{l}\text { BNL } \\
\text { Blanket }\end{array}$ & UWMAK-II & PPPL & ORNL & $\begin{array}{l}\text { Theta } \\
\text { Pinch }\end{array}$ & Mirror & Blascon & $\begin{array}{l}\text { Wet } \\
\text { Wall }\end{array}$ & $\begin{array}{l}\text { Suppressed } \\
\text { Ablation }\end{array}$ \\
\hline $\begin{array}{l}\text { Net electrical } \\
\text { power output, } \\
\text { MWe }\end{array}$ & 1000 & 1000 & 1000 & 1000 & 1000 & 1000 & 1000 & Unspecified & 1000 & 1000 \\
\hline $\begin{array}{c}\text { Nuclear thermal } \\
\text { power, MWt }\end{array}$ & 3166 & 3115 & 2756 & 2613 & 1931 & 2905 & 3756 & & 3745 & 2815 \\
\hline $\begin{array}{l}\text { Total electrical } \\
\text { power generated, } \\
\text { MWe }\end{array}$ & 1142 & 1071 & 1057 & 1185 & 1089 & 1234 & 4352 & & 1500 & 1370 \\
\hline $\begin{array}{l}\text { Fuel feed rate. } \\
\mathrm{kg} / \text { day }\end{array}$ & $\mathrm{T} \cdot 5.7 ; 0.3 .8$ & $T-5.2 ; D-3.5$ & & T-3.0; D-2.0 & $\mathrm{T}-1.2 ; D-0.77$ & $\mathrm{~T}-7.4 ; 0-4.9$ & T.5.3; D.5.9 & & T-1.9; D-1.3 & $\mathrm{T}-1.9 ; 0 \cdot 1.3$ \\
\hline $\begin{array}{l}\text { Fuel consump- } \\
\text { tion rate, } \mathrm{kg} / \text { day }\end{array}$ & $\begin{array}{l}\mathrm{T}-0.47 \\
\mathrm{D}-0.31\end{array}$ & $\begin{array}{l}\text { T- } 0.43 \\
D-0.29\end{array}$ & & $\begin{array}{l}\mathrm{T}-0.26 \\
\mathrm{D}-0.17\end{array}$ & $\begin{array}{l}\mathrm{T}-0.23 \\
\mathrm{D}-0.15\end{array}$ & $\begin{array}{l}T \cdot 0.35 \\
D \cdot 0.23\end{array}$ & $\begin{array}{l}\text { T. } 0.47 \\
\text { D- } 0.31\end{array}$ & & $\begin{array}{l}\mathrm{T}-0.42 \\
\mathrm{D}-0.29\end{array}$ & $T-0.40 ; D-0$ \\
\hline Primary coolant: & $\mathrm{Li}$ & $\mathrm{He}$ & $\mathrm{He}$ & $\mathrm{He}$ & $\mathrm{Li}$ & $\mathrm{Li}$ & $\mathrm{Li}$ & $\mathrm{Li}$ & $\mathrm{Li}$ & $\mathrm{Li}$ \\
\hline Mass flow, $\mathrm{kg} / \mathrm{hr}$ & $2.2 \times 10^{7}$ & $2.6 \times 10^{6}$ & $8.8 \times 10^{6}$ & $5.9 \times 10^{6}$ & $6.2 \times 10^{7}$ & $2.0 \times 10^{7}$ & & & $1.2 \times 10^{7}$ & $3.0 \times 10^{6}$ \\
\hline Mass, $\mathrm{kg}$ & $1.2 \times 10^{6}$ & $5.7 \times 10^{3}$ & $2.3 \times 10^{3}$ & $2.0 \times 10^{4}$ & $8.9 \times 10^{6}$ & $2.1 \times 10^{5}$ & & & & \\
\hline $\begin{array}{l}\text { Intermediate } \\
\text { coolant: }\end{array}$ & $\mathrm{Na}$ & - & $\mathrm{Na}$ & & k & $\mathrm{Na}$ & $\mathrm{He}$ & NaK & $\mathrm{Na}$ & Unspecified \\
\hline Mass flow, $\mathrm{kg} / \mathrm{hr}$ & $8.1 \times 10^{7}$ & & $3.0 \times 10^{7}$ & & $3.5 \times 10^{6}$ & $4.8 \times 10^{7}$ & & & & \\
\hline Mass, $\mathrm{kg}$ & $1.2 \times 10^{?}$ & & $4.9 \times 10^{6}$ & & $1.9 \times 10^{4}$ & & & & & \\
\hline Steam flow, $\mathrm{kg} / \mathrm{hr}$ & $5.1 \times 10^{6}$ & $2.4 \times 10^{6}$ & $3.6 \times 10^{6}$ & $3.3 \times 10^{6}$ & $2.9 \times 10^{6}$ & $5.1 \times 10^{6}$ & & & & \\
\hline $\begin{array}{l}\text { Waste heat } \\
\text { dissipation, MW }\end{array}$ & 2074 & 2115 & 1754 & 1613 & 832 & 1985 & 2647 & & 2730 & 1740 \\
\hline $\begin{array}{l}\text { Vacuum pumping } \\
\text { speed, liters/sec }\end{array}$ & $1.8 \times 10^{8}$ & & & $3.3 \times 10^{5}$ & $9.7 \times 10^{4}$ & $5.6 \times 10^{5}$ & $3.3 \times 10^{8}$ & & $2 \times 10^{4}$ & $1.1 \times 10^{6}$ \\
\hline $\begin{array}{l}\text { Tritium } \\
\text { Parameters }\end{array}$ & UWMAK-I & $\begin{array}{l}\text { BNL } \\
\text { Blanket }\end{array}$ & UWMAK-II & PPPL & ORNL & $\begin{array}{l}\text { Theta } \\
\text { Pinch }\end{array}$ & Mirror & Blascon & $\begin{array}{l}\text { Wet } \\
\text { Wall }\end{array}$ & $\begin{array}{l}\text { Suppressed } \\
\text { Ablation } \\
\end{array}$ \\
\hline $\begin{array}{l}\text { Amount bred, } \\
\mathrm{kg} / \text { day }\end{array}$ & 0.70 & 0.52 & 0.4 & 0.27 & 0.31 & 0.39 & 0.53 & & 0.5 & 0.58 \\
\hline $\begin{array}{l}\text { Total plant } \\
\text { inventory, kg }\end{array}$ & 16.0 & 6.3 & 10.2 & 1.3 & 11.1 & 0.92 & & & & \\
\hline $\begin{array}{l}\text { Total active } \\
\text { inventory, } \mathrm{kg}\end{array}$ & 9.2 & 0.08 & 2.7 & 0.28 & 0.27 & 0.58 & & & & \\
\hline Blanket & & 0.009 & 0.2 & 0.005 & & & & & & \\
\hline Coolant & 5.9 & 0.0006 & 0.1 & 0.005 & 0.23 & 0.085 & & & & \\
\hline Structure & & & & 0.015 & 0.04 & & & & & \\
\hline Gettering system & 3.1 & 0.004 & 2.3 & & & 0.092 & & & & \\
\hline Fuel system & 0.2 & 0.067 & & 0.25 & & 0.397 & & & & \\
\hline Cryopumps & & & 0.1 & & & & & & & \\
\hline Storage, $\mathrm{kg}$ & 6.8 & 6.2 & 7.5 & 1.0 & 10.8 & 0.35 & & & & \\
\hline
\end{tabular}


TABLE 6 Normalized Fusion Power Plant Material Requirements for Construction, Per 1000 Mwe Net Output (metric tons)

\begin{tabular}{|c|c|c|c|c|c|c|c|c|}
\hline Element & $\begin{array}{l}\text { UWMAK-I(a) } \\
\text { Total } \\
\end{array}$ & $\begin{array}{c}\text { BNL Blanket(b) } \\
\text { Blanket and } \\
\text { Shield } \\
\end{array}$ & $\begin{array}{l}\text { UWMAK-II (a ) } \\
\text { Total } \\
\end{array}$ & $\begin{array}{c}\mathrm{PPPL}(\mathrm{c}) \\
\text { Total } \\
\end{array}$ & $\begin{array}{l}\text { ORNL(d) } \\
\text { Nuclear } \\
\text { Island } \\
\end{array}$ & $\begin{array}{l}\text { Theta } \\
\text { Pinch(e) } \\
\text { Total } \\
\end{array}$ & $\begin{array}{l}\text { Mirror }(f) \\
\text { Reactor and } \\
\text { Convertor } \\
\end{array}$ & $\begin{array}{l}\text { Typical } \\
\text { LMFBR }\end{array}$ \\
\hline $\mathrm{Al}$ & 540 & 1,550 & 1,340 & & & & & 40 \\
\hline B & 1,070 & 3,610 & 2,500 & & & & & \\
\hline $\mathrm{Be}$ & & 120 & 430 & & & 12 & & \\
\hline C & 300 & 1,960 & 2,860 & 430 & 2,120 & 170 & 1,400 & \\
\hline $\mathrm{Cr}$ & 7,920 & & 2,860 & 820 & 70 & & 44,000 & 400 \\
\hline $\mathrm{Cu}$ & 7,270 & & 6,500 & 1,610 & 870 & 2,270 & 52,000 & 700 \\
\hline $\mathrm{Fe}$ & 77,800 & & 53,900 & 5,870 & 12,400 & & 146,000 & 34,000 \\
\hline $\mathrm{He}$ & 90 & & 50 & 60 & 2 & 290 & & \\
\hline $\mathrm{Hg}$ & 2 & & & & & & & \\
\hline$k$ & & & & & 20 & & & \\
\hline $\mathrm{Li}$ & 1,150 & 40 & 210 & 290 & 890 & 390 & 490 & \\
\hline Mn & 820 & & 46 & 80 & & & 4,400 & 40 \\
\hline Mo & 410 & & 300 & 140 & & & & 40 \\
\hline $\mathrm{Na}$ & 12,100 & & 5,740 & & & & & 2,000 \\
\hline Nb & 90 & & 90 & 50 & 1,930 & 880 & & \\
\hline $\mathrm{Ni}$ & 5,900 & & 3,180 & 810 & 50 & & 27,000 & 300 \\
\hline $\mathrm{Pb}$ & 13,900 & & 11,600 & & 10,300 & & 7,500 & 50 \\
\hline Sn & & & & 20 & & 70 & & \\
\hline $\mathrm{Ti}$ & 50 & & 60 & 8 & 1,240 & & & \\
\hline$Y$ & 3 & & 2 & & & & & \\
\hline $\mathrm{Zr}$ & 70 & & 60 & 0.5 & & & & \\
\hline Concrete & 461,000 & & 398,000 & 15,800 & 38,600 & & 225,000 & 180,000 \\
\hline
\end{tabular}

a. Not including turbine, cooling towers, switch gear. Differs from design document-replacement

b. $\mathrm{Bl}$ lanket and shield major components only. Feedstock for ${ }^{6} \mathrm{Li}$ enrichment included.

c. Reactor building contents (major components) only.

d. Nuclear Is land major components only.

e. Major plant components only. Buildings not included. Feedstock for ${ }^{6}{ }_{L i}$ enrichment included.

f. Reactor optimized for small size, not minimal material usage. Requirements estimated from description. 
TABLE 7 Normalized Fusion Power Plant Material Requirements for Operation. Average annual replacement quantities per 1000 MWe net output (metric tons).

\begin{tabular}{|c|c|c|c|c|c|c|c|}
\hline Element & UWMAK-I (a) & $\begin{array}{c}\text { BNL } \\
\text { Blanket (b) } \\
\end{array}$ & UWMAK-II ${ }^{(c)}$ & PPPL (d) & ORNL $^{(\mathrm{e})}$ & Theta Pinch ${ }^{(f)}$ & Mirror $(\mathrm{g})$ \\
\hline Al & 4.9 & 157. & 49 & & & & \\
\hline $\mathrm{Be}$ & & 0.6 & 10.8 & & & 2.4 & \\
\hline C & & 108. & & & 212. & 34. & 66. \\
\hline $\mathrm{Cr}$ & 87. & & 88 & 19. & & & 37. \\
\hline $\mathrm{Cu}$ & 4.9 & & 4.9 & & & 0.5 & \\
\hline $\mathrm{Fe}$ & 302. & & 304 & 42. & & & 118. \\
\hline $\mathrm{He}$ & & & & & & 0.2 & \\
\hline Li & & 3. & 12.3 & & & 3.9 & \\
\hline$M n$ & 9.5 & & 9.8 & & & & \\
\hline Mo & 9.5 & & 9.8 & & & & 3.7 \\
\hline $\mathrm{Nb}$ & & & & & 27. & 19. & \\
\hline $\mathrm{Ni}$ & 68. & & 69 & 46. & & & 22. \\
\hline $\mathrm{Zr}$ & & & & & 0.3 & & \\
\hline
\end{tabular}

a. Due to 316 SS replacement. $32 \%$ due to replacement of inner blanket every 2 years; $68 \%$ due to -replacement of remainder of blanket every 10 years.

b. Replace one-third of blanket modules each year.

c. Stainless steel replacement: $82 \%$ due to inner blanket replacement every 2 years; $18 \%$ due to replacement of remainder of blanket every 10 years.

d. Due to $\mathrm{Pe}-16$ replacement; one-fifth of blanket each year.

e. Replace blanket every 10 years.

f. Replace one-fifth of blanket modules each year.

g. Blanket life is not estimated in the design. 304 SS structure and first wall loading are similar to UWMAK-I. Table is based upon replacement schedule postulated by rough analogy to UWMAK-I. Replacement of inner $30 \mathrm{~cm}$ of blanket every 2 years; replacement of outer $70 \mathrm{~cm}$ of blanket every 10 years; 30 year plant 1 ife. 


\subsection{DESCRIPTIONS OF DESIGN CONCEPTS}

\subsection{Tokamak Magnetic Confinement}

A Tokamak fusion reactor has a toroidal plasma chamber which contains entire magnetic field loops. Although charged plasma particles spiraling about magnetic field lines are individually confined by a simple toroidal field, plasma instabilities (including gross motion of the plasma as a whole) require a more complex magnetic field structure for containment. Plasma stabilization requires that the circular field loops be distorted into helices. This is accomplished by inducing a current in the plasma ring which creates its own magnetic field. The field lines produced by the combined effects are a nested set of helices whose pitch angles vary with radial position within the torus cross section.

Tokamak confinement also requires a verticle magnetic field perpendicular to the plane of the torus, to stabilize the major radius of the plasma ring. Curvature of this field provides vertical stability to the plasma ring, thus keeping it centered in the toroidal plasma chamber.

In some designs the vertical field is modified so that plasma particles diffusing outward from the plasma are diverted to special chambers for collection. This modification of the vertical field is called a divertor field. The divertor field combines with the toroidal confining field so that field lines balloon outward in certain places outside the plasma (but inside the plasma chamber) leading escaping plasma into the collection chambers.

A portion of the vertical field passes through the "doughnut hole" along the major axis of the torus. Since this field does not intersect the plasma it functions only indirectly to confine the plasma, inducing the plasma current by transformer action.

The magnet coils which produce the toroidal and vertical magnetic fields are called toroidal field coils, verticai field coils, divertor coils and transformer coils. The mode of operation is not the same for all magnet coils. Although the toroidal field may be held constant, the vertical fields must be pulsed on and off during each reactor cycle. The reactor burn cycle length is determined by the transformer coil capacity. Not only do flux changes through this coil induce the plasma current, they are required to sustain the current against resistive losses. When the flux 1 imit of the transformer coil is reached the burn must be ended and the transformer "recocked." To maintain plasma stability while the plasma current is thus changed, it is necessary to simultaneously change the vertical and divertor fields.

These features of plasma confinement are common to the five tokamak reactors described in this section.

\subsubsection{University of Wisconsin Tokamak (UWMAK-I)}

Summary Description - The UWMAK-I power plant ${ }^{(3)}$ produces 1473 megawatts of net electrical power (MWe) on a continuous basis from an average thermal energy release of 4663 megawatts thermai (MWt). The thermonuclear burn cycle of the tokamak is 96.5 minutes long, of which shutdown and refueling require 6.6 minutes. Continuous electrical generation is achieved by accumulating part of the hot intermediate coolant during the burn, to generate steam during the shutdown period. Overall power plant layout is shown in Figure 2. 


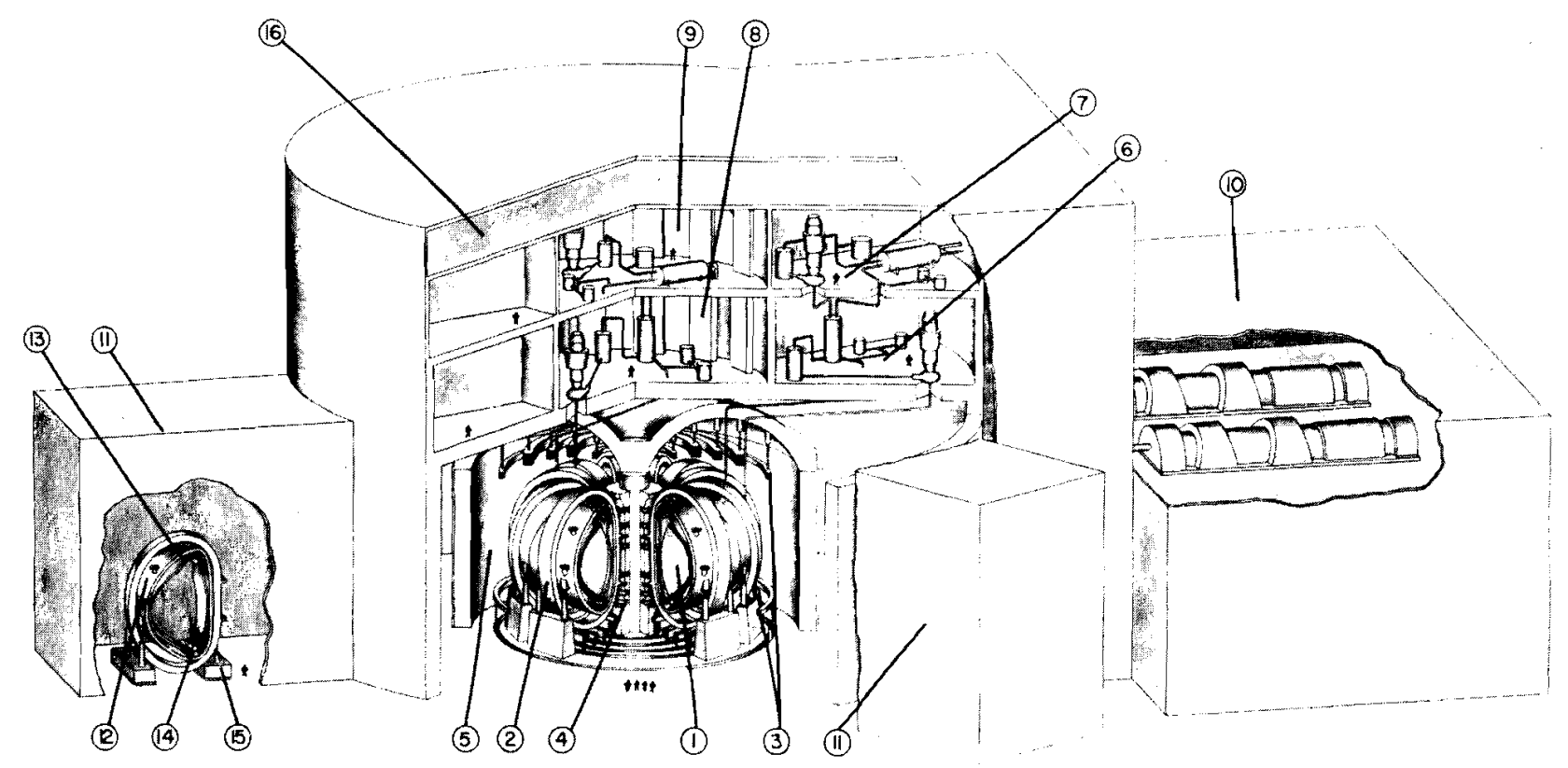

1. PLASMA

2. TOROIDAL FIELD COIL (12)

3. RETRACTABIF DIVERTOR COIL (8)

4. TRANSFORMER COIL (10)

5. EVACUATED PRIMARY CONTAINMENT BUILDING
6. Li PRIMARY SYSTEM IONE FOR EACH OF 12 MODULESI

7. Na SECONOARY SYSTEM IONE FOR EACH OF 12 MODULESI

8. DIVERTOR LI PRIMARY SYSTEM.

9. DIVERTOR Na SECONDARY SYSTEM

10. TURB INE-GENERATOR BUILDING
11. HOT CELL REPAIR AREA

12. MAGNET SHIELD

13. BLANKET

14. OIVERTOR COLLECTION AREA

15. MOTORIZEO MODULE SUPPORT VEHICLE

16. AUXILIARY EQUIPMENT AREA

\section{FIGURE 2 UWMAK-I Power Plant Building}

The reactor is cooled by molten lithium metal which also functions as a neutron moderator and a fertile material to breed tritium fuel. This primary coolant exchanges heat to a low-radioactive sodium intermediate coolant, which transports it to steam generators. Steam, at $404^{\circ} \mathrm{C}$ and $140 \mathrm{~kg} / \mathrm{cm}^{2}$, is used to drive the turbine-generators. Major power plant systems are identified and their functional relations are indicated in Figure 3.

The reactor is located inside a containment building which provides two levels of containment. An evacuated cell immediately encloses the reactor and the reactor building itself encloses both the lithium and sodium coolant loops and processing equipment, in addition to the reactor cell. An inert gas is maintained around the primary coolant piping and processing equipment, to prevent liquid lithium metal fires.

The diameter of the reactor is 43 meters. The major and minor radii of its toroidal plasma chamber are $13 \mathrm{~m}$ and $5.5 \mathrm{~m}$. It is constructed primarily of Type 316 stainless steel (SS) structural material.

Plasma confinement is achieved by superconducting magnets designed for complete cryogenic stability. Niobium-titanium superconductor cooled by liquid helium is used in the toroidal plasma confinement coils, the plasma current transformer, and the poloidal divertor. The toroidal 


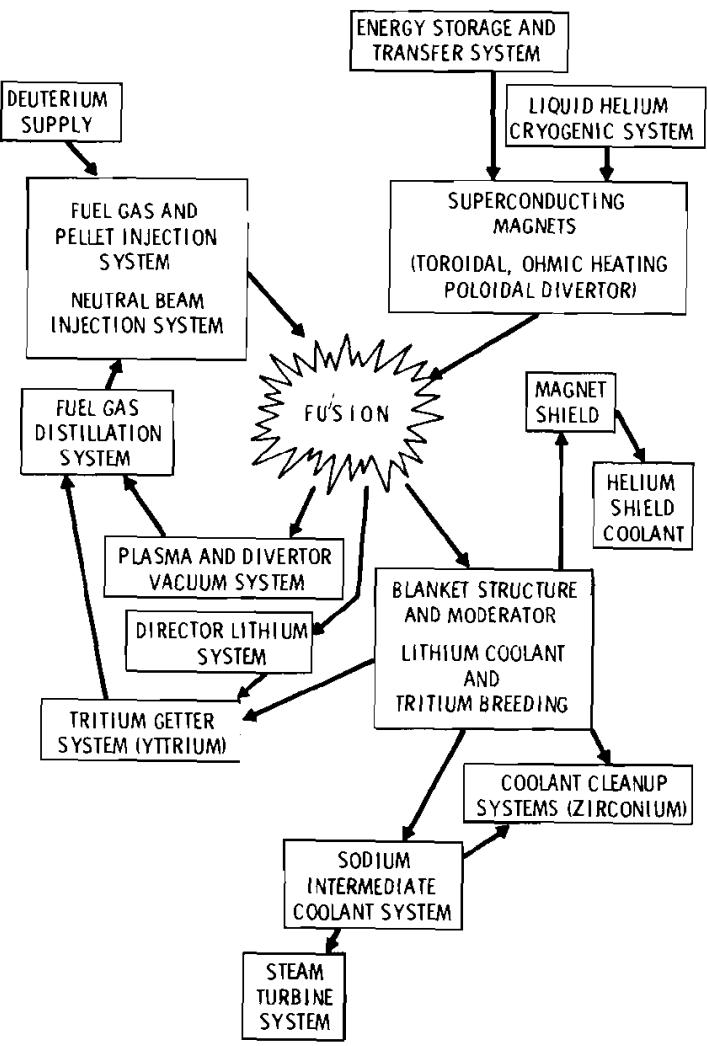

FIGURE 3 Functional Relations Between Systems of the UWMAK-I Tokamak Power Plant

magnetic field is produced by 12 coils having a bore diameter of $21.5 \mathrm{~m}$. Maximum and plasmacenter magnetic fields are 8.7 and 3.8 tesla $(T)$. Plasma stability is maintained by additional magnetic fields produced by the plasma current and by the poloidal divertor coils.

During reactor startup, fuel gas ionization and establishment of the plasma current is achieved by air-core transformer action of both the transformer and divertor coils. Escaping plasma particles are guided to collection chambers by the magnetic field of the divertor coils. This protects the plasma chamber wall from erosion, and protects the plasma from sputtered impurities. The plasma is heated ohmically by the plasma current of 21 megamperes (MA). However, to achieve ignition of the thermonuclear burn, additional heating by neutral atom beams carrying 15 megawatts (MW) of power is required for 11 seconds. The projected injection of 30 amperes equivalent of $500 \mathrm{keV}$ neutral atoms represents a considerable extrapolation of existing technology. The plasma contains equal numbers of deuterium and tritium atoms, plus a $1 \%$ addition of argon impurity atoms. The plasma chamber fuel charge is $1.3 \mathrm{gram}(\mathrm{g})$ of tritium and $0.9 \mathrm{~g}$ of deuterium. The plasma ion temperature is $11 \mathrm{keV}$, and its kinetic energy content is 3 gigajoules. Fuel is injected into the plasma in pellet form by an undefined injector. The fuel injection rate is $8.4 \mathrm{~kg} /$ day of tritium and $5.6 \mathrm{~kg} /$ dav of deuterium. Only $7 \%$ of it is burned before 
escaping from the plasma, yielding a fuel consumption rate of $0.7 \mathrm{~kg} /$ day of tritium and $0.5 \mathrm{~kg} /$ day of deuterium. Unburned fuel is purified by cryogenic distillation and recycled to the plasma.

Energy collection and tritium breeding take place in a 73.5 centimeters $(\mathrm{cm})$ thick blanket located inside the magnet coils adjacent to the plasma. Further attenuation of particles and radiation is provided by a $77 \mathrm{~cm}$ thick shield located between the blanket and the superconducting magnets. Evacuated spaces between blanket and shield, and between shield and magnets provide thermal insulation for the cryogenic magnets. The blanket and shield regions are indicated in Figure 2.

The blanket is constructed of Type 316 SS, and it contains liquid lithium metal coolant. The innermost $20 \mathrm{~cm}$ of the blanket consists of ducting for the flow of liquid lithium. This region is followed by $31 \mathrm{~cm}$ of headers that supply and remove the lithium, and support the ducting. The outermost $20 \mathrm{~cm}$ of the blanket is a Type 316 SS neutron reflector containing two flow channels for lithium coolant. A section view of the reactor is presented in Figure 4. The toroidal blanket is composed of 12 separate $30^{\circ}$ sectors, each associated with one magnet coil.

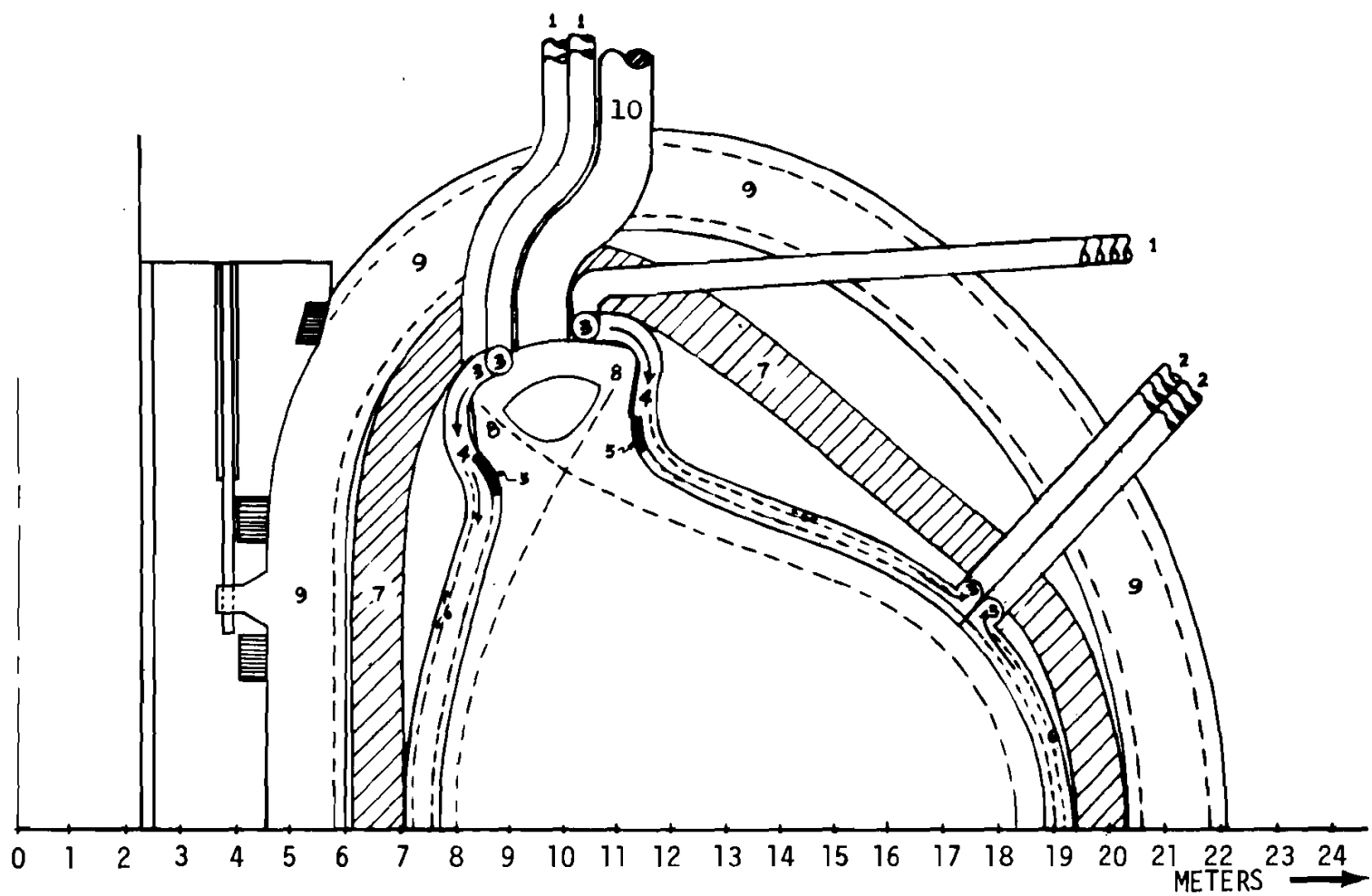

1. Feed Pipes 4. Poloidal Headers and Connectors 7. Shield

2. Discharge Pipes 5. Radial Flow Cells

3. Toroidal Headers 6. Stainless Steel Reflector

8. Divertor Slots

9. Superconducting Magnets

10. Vacuum Duct

FIGURE 4 Section View of a Toroidal Module of UWMAK-I 
Radiation induced embrittlement of the stainless steel structure requires replacement of the inner $20 \mathrm{~cm}$ of the blanket after 2 years in the reactor, and replacement of the remainder of the blanket after 10 years. This results in an average rate of solid waste production of 730 metric tons per year (MT/yr). An additional $2.8 \mathrm{MT} / \mathrm{yr}$ of corrosion products is expected to be removed from the 1 ithium coolant.

Twelve independent lithium/sodium/steam coolant loops, one for each blanket sector, remove heat from the blanket. Blanket temperatures are limited by the necessity of keeping the temperature of stainless steel in contact with liquid 1 ithium below $500^{\circ} \mathrm{C}$. Hot leg temperatures in the lithium, sodium and steam loops are $489^{\circ} \mathrm{C}, 456^{\circ} \mathrm{C}$ and $404^{\circ} \mathrm{C}$, respectively. Liquid metal pumps, heat exchangers and steam generators use Liquid Metal Fast Breeder (LMFBR) technology.

Electricity is generated by two identical tandem compound turbine-generators at a thermal efficiency of $36 \%$. The net plant efficiency is $32 \%$.

Spent fuel escaping from the plasma is collected by the divertor, at the rate of $7.7 \mathrm{~kg} / \mathrm{day}$ of tritium, $5.1 \mathrm{~kg} /$ day of deuterium and $0.9 \mathrm{~kg} /$ day of helium. Most of this is trapped in sheets of flowing liquid 1 ithium provided for that purpose. The $4 \%$ which escapes trapping is collected by the 192 vacuum pumps which maintain the plasma chamber vacuum. Plasma energy deposited in the divertor lithium is transferred to a sodium intermediate coolant and used to generate steam for feedwater heating.

About $1.0 \mathrm{~kg} /$ day of tritium is bred in the lithium coolant/fertile material at the breeding ratio of $1: 49$. This is recovered from a cold-leg side stream by passing it through a bed of $0.1 \mathrm{~mm}$ thick yttrium metal foil which absorbs it. The same method is used to recover spent fuel trapped in the divertor lithium stream, and tritium which permeates into the sodium intermediate coolant.

The total plant inventory of tritium is $23.5 \mathrm{~kg}$, of which $10 \mathrm{~kg}$ is in storage. Of the active inventory, $9.7 \mathrm{~kg}$ is in the primary coolant and recovery beds, $3.5 \mathrm{~kg}$ is in the divertor-lithium recovery beds, and the remainder is in the cryogenic vacuum pumps.

Additional information on the UWMAK-l power plant is presented in the following sections which discuss the major plant systems and structures.

Plasma Confinement Systems for the UWMAK-I Design - The magnet coils specified for plasma confinement in this design are called toroidal field coils, poloidal divertor coils and poloidal transformer coils. The divertor coils produce a field with appropriate vertical characteristics to stabilize. the plasma ring, hence no coils are designated as "vertical field coils" in this design.

All three sets of coils are to be superconducting and they are to be constructed from a large cross section Nb-Ti superconductor. Liquid helium cryogenic cooling is to be used. These magnets are designed for complete cryogenic stability, which means that sufficient copper is included in the superconductor that the entire current could be carried by the copper without the attendant joule heating raising the temperature above $5.2^{\circ} \mathrm{K}$. 
The toroidal field magnets each weigh 900 metric tons and 12 of them are evenly spaced around the torus. They are "D" shaped to minimize large bending forces in the coils. They are supported by a massive central cylindrical structure, which also acts during operation to resist the large magnetic forces pushing the D's toward the major axis of the torus. The cross section view of figure 5 shows the cylinder, a coil, and the method of attachment. Coil geometry and dimensions are indicated in Figure 6.

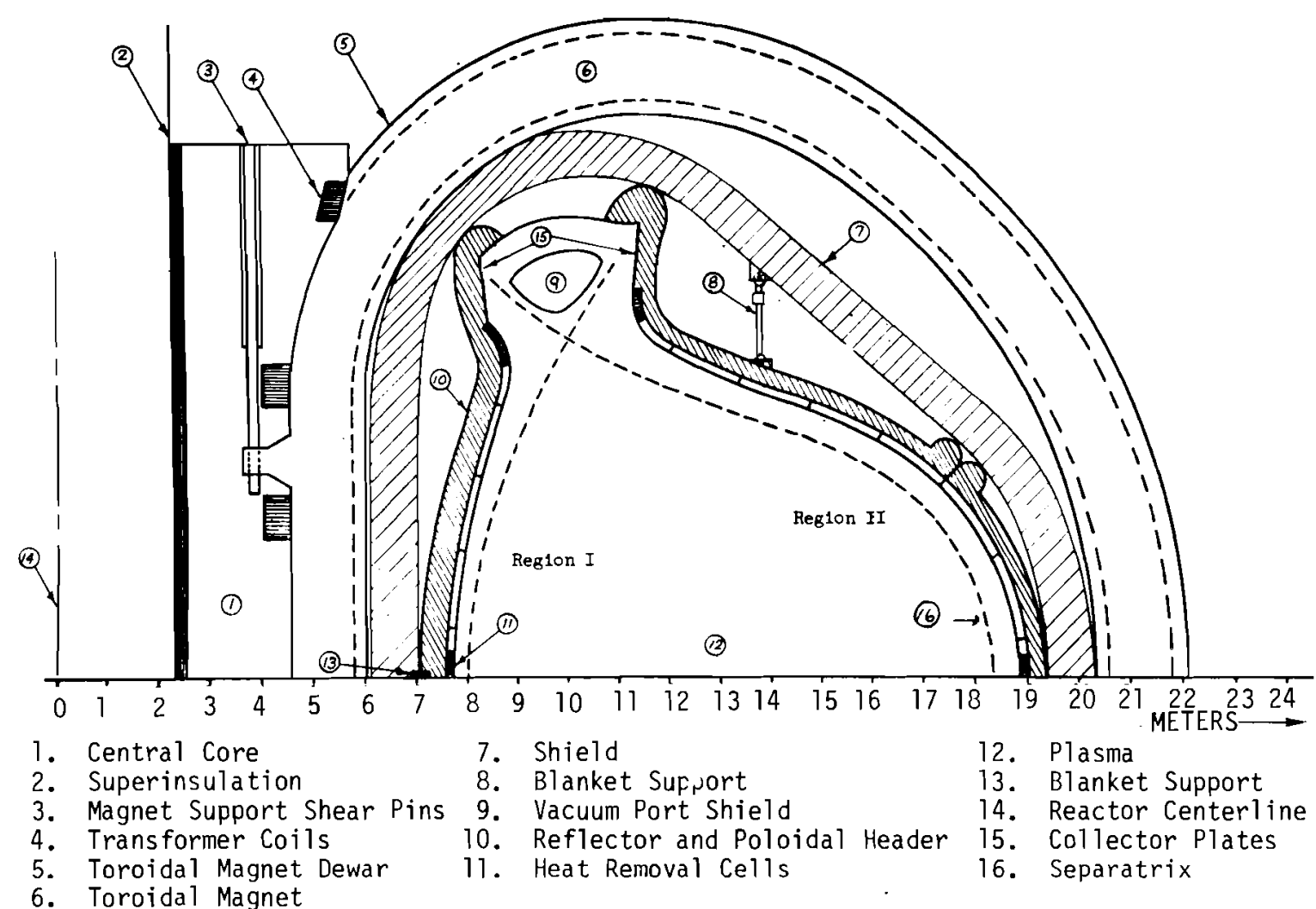

FIGURE 5 Cross Section of UWMAK-I

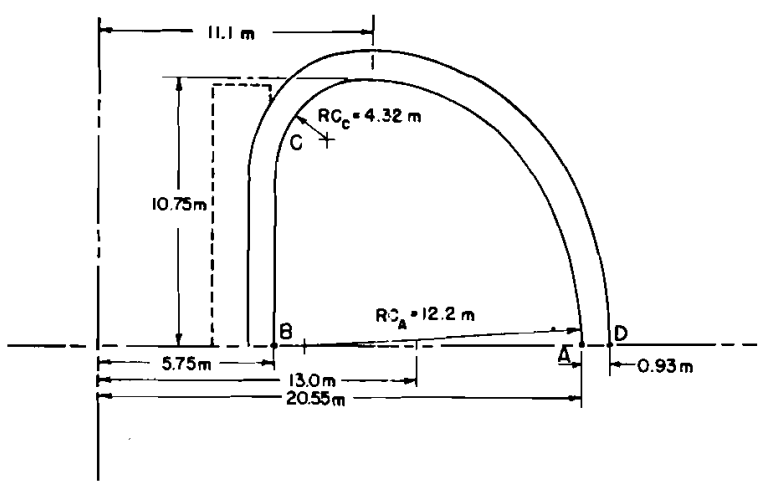

FIGURE 6 Stainless Steel Structural Disc for "D" Shaped Toroidal Field Magnet in UWMAK-I 
Each of the toroidal $D^{\prime} \mathrm{s}$ is laminated from 34 separate stainless steel D's. Each of the D's is $5 \mathrm{~cm}$ thick, and carries a thick strip of superconductor recessed into it in spiral grooves. The superconductor is potted securely in the grooves with fiberglass epoxy. The lamina are separated by grooved micarta spacers which allow direct contact of the liquid helium coolant with the edge of each strip of superconductor. The superconductor current will be 10,212 amperes, at a gross current density of $1.3 \mathrm{kA} / \mathrm{cm}^{2}$. This produces an on-axis field of $3.8 \mathrm{~T}$ at the center of the plasma. The fields at points $A, B$ and $C$ of Figure 6 will be $2.4 \mathrm{~T}, 8.7 \mathrm{~T}$ and $6.3 \mathrm{~T}$.

The magnet coils will be encased in a stainless steel shell which will contain liquid helium. This is the inner wall of an evacuated dewar providing thermal insulation to the magnet. Lateral magnet bracing is provided, including fiberglass-epoxy struts inside the dewars, to support the large forces which might develop in the event of a magnet failure during operation. The central support column will also be refrigerated to liquid helium temperatures, since no superinsulation exists that can resist the compressive forces involved.

The transformer and divertor coils are located outside of the toroidal magnet coils. The transformer coils are located so as to produce a flux through the center of the torus but negligible magnetic field in the vicinity of the plasma. In contrast, the divertor coils produce a flux through both the central and the plasma regions. The relative locations of the 10 transformer and 8 divertor coils are indicated on the schematic cross section of Figure 7 . The current carried by these coils ranges from 24 MA to 2 MA in proportion to the coil size indicated on the figure.

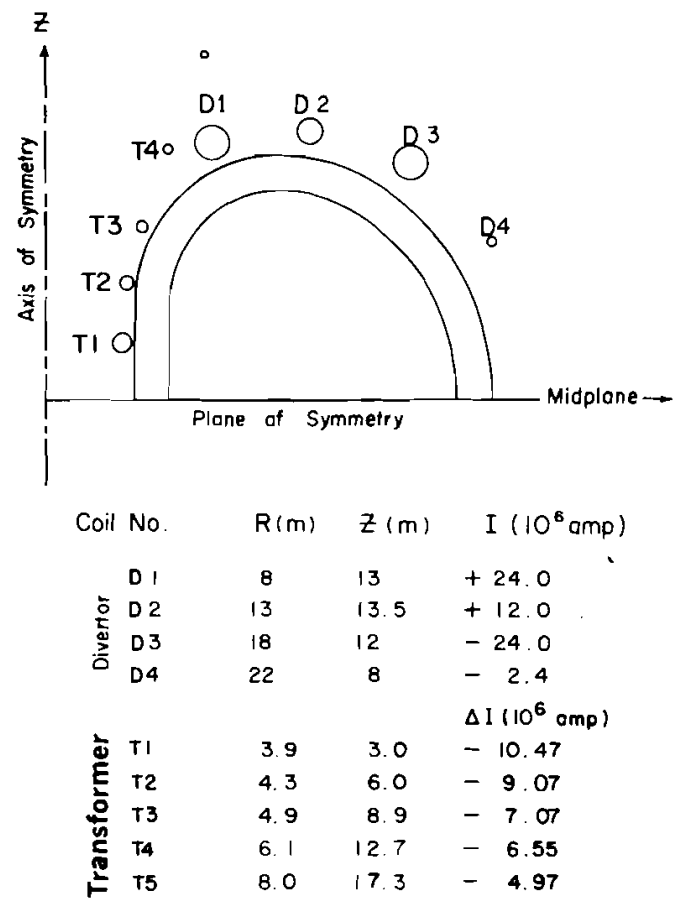

FIGURE 7 Reactor Cross Section of UWMAK-I Showing Locations of Transformer and Divertor Coils. (Coils are located symmetrically below the reactor midplane also.) 
The transformer and divertor coils utilize a layer-wound pancake design, since a continuous steel support disc would incur large eddy current losses during the rapid magnetic field changes of startup and shutdown. Superconductor and stainless steel supporting strips are wound into pancakes and stacked and clamped as shown in Figure 8. Spacers between the pancakes allow liquid helium cooling of the edges of all superconductor strips.

During reactor startup, fuel gas ionization and establishment of the 21 MA plasma current is achieved by air-core transformer action of both the transformer and divertor coils. (These coils provide $40 \%$ and $60 \%$, respectively, of the required flux changes.) The currents in the divertor coils must start from zero to prevent dispersal of the plasma. This is not necessary for the transformer coils, however, and currents are changed from $+I$ to -I during startup.

The divertor field functions to provide vertical and radial stability to the plasma ring, and to guide escaping plasma particles to collection chambers. The fields of the divertor coils combine with the field of the plasma current and toroidal field coils so that outside of the dotted separatrix (Figure 5) they lead into the collection regions indicated at the top and bottom of the reactor blanket. There the particles are collected in a liquid lithium stream flowing over collector plates.

Considerable energy is stored in the magnetic fields of this reactor. The total stored magnetic energy is 240 gigajoules, of which 160 gigajoules are stored in the toroidal magnetic field.

Plasma Heating System for the UWMAK-I Design - The plasma current of 21 MA, which is required for confinement stability, also functions to heat the plasma through the resistive effects of electron-ion collisions. However, the plasma resistivity (and thus the heating) decreases with temperature, while plasma energy losses (due to particle escape, bremsstrahlung and synchrotron heating) increase with temperature. Consequently, this ohmic heating method must be supplemented to achieve ignition of the thermonuclear burn.

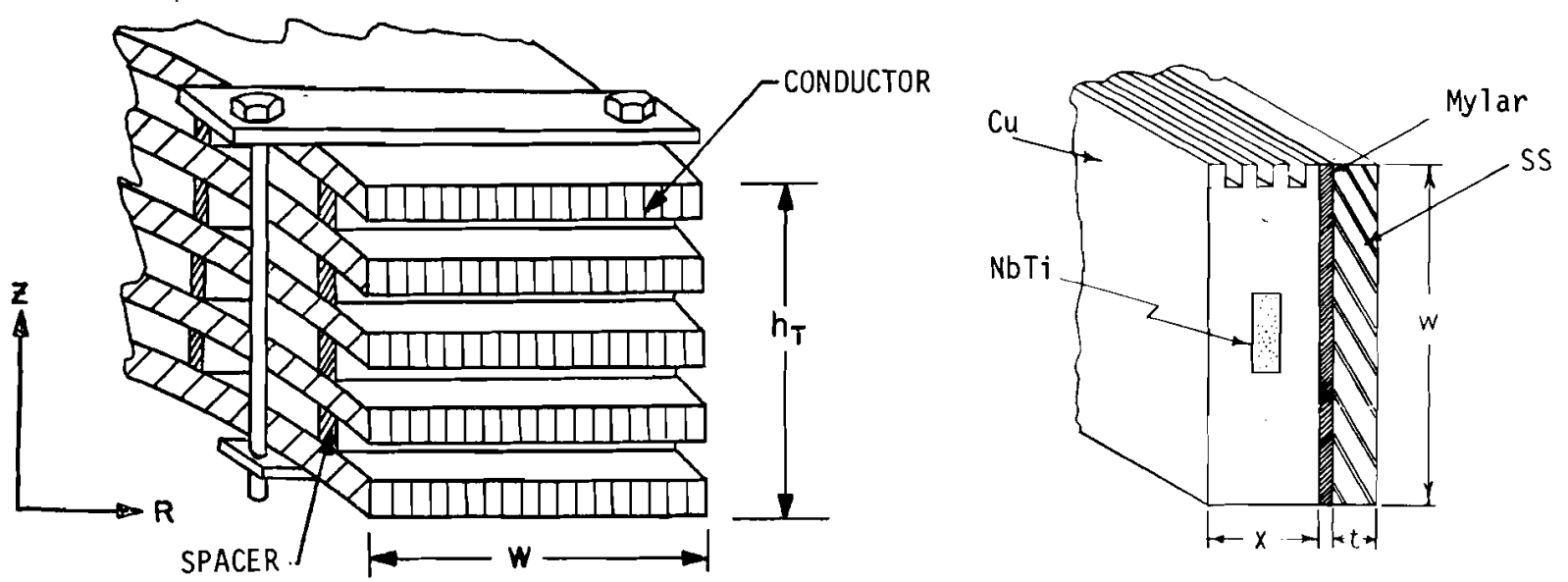

FIGURE 8 Layer-Wound Pancake Construction of Transformer and Divertor Coils in UWMAK-I 
The injection of energetic beams of neutral fuel atoms is used to supply enough additional energy to heat the plasma to ignition conditions. Neutral beam injection begins immediately after the 100 seconds required to induce the ful1 plasma current. Injection of $15 \mathrm{MW}$ of neutral beam power for 11 seconds is expected to yield ignition, at which time the beams are to be turned off. Twenty injectors, each supplying an equivalent beam current of 1.5 amperes, are required.

The injection energy of the neutral beams is 500 kiloelectron volt (keV). Injection at this rather high energy is required to achieve adequate beam penetration and heating of the central plasma region. Plasma heating and ignition are to take place at an ion density below that for regular operation $\left(3 \times 10^{13} \mathrm{~cm}^{-3}\right.$ versus $1.2 \times 10^{14} \mathrm{~cm}^{-3}$ axial density). This enhances penetration of the beams, and also reduces the amount of energy that must be supplied to heat the plasma to ignition.

The projected beam sources represent a considerable extrapolation of existing technology, especially in terms of beam power and pulse duration. Only the basic design concepts have been described. The neutral beam is to be produced by stripping electrons from energetic negative ions by passing them through a gas cell, a much more efficient process than that of neutralizing a beam of positive ions. The negative ion beam is produced by passing a positive ion beam through a cesium gas cell. While the production of negative ions is not an efficient process, it is done at low beam energies so energy losses are not excessive. Energy losses following acceleration are minimized by the high efficiency of the negative ion neutralization process.

The initial positive ion beam is to be produced in a scaled-up version of an existing plasma source. That beam is to be converted, by passage through a series of cesium gas cells, to a negative ion beam which serves as the source for the subsequent $500 \mathrm{kV}$ acceleration system. The accelerator has four stages (each adding $125 \mathrm{keV}$ to the beam) and requires five electrodes. To avoid beam divergence due to space charge effects at high currents, multi-aperture electrodes are required. Specifically, electrodes $19.5 \mathrm{~cm}$ in diameter are to be used, each having 2125 holes $3 \mathrm{~mm}$ in diameter which must be aligned for passage of the ion beam. The electrodes are to be constructed of molybdenum and be at least $3 \mathrm{~mm}$ thick to prevent excessive heating and bowing during the 11 second startup. Following acceleration, the possibility of magnetically focusing the beam prior to its neutralization and transit to the plasma is noted.

Milligram quantities of deuterium and tritium will be injected during each of the 16 daily reactor startups.

Fuel System on the UWMAK-I Design - During operation $2 \times 10^{22}$ atoms per second of deuterium and tritium must be supplied to the plasma, requiring the injection of $8.4 \mathrm{~kg} / \mathrm{day}$ of tritium and $5.6 \mathrm{~kg} /$ day of deuterium. (The fuel also contains a 1\% addition of argon atoms.) On7y $7 \%$ of the fuel undergoes fusion reactions, however, before it escapes from the plasma. The actual consumption of fuel in fusion reactions is $0.69 \mathrm{~kg} /$ day of tritium and $0.46 \mathrm{~kg} /$ day of deuterium. The fuel system separates unburned fuel from recycled plasma and purifies it and the tritium bred in the blanket. The fuel system prepares fuel in the form necessary for injection and injects it appropriately into the plasma. 
About $14 \mathrm{~kg} /$ day of recycled plasma and bred tritium must be purified by an undefined process. This process must remove: the helium ash from fusion $(0.9 \mathrm{~kg} /$ day $)$; whatever impurities may be sputtered from the vacuum chamber or may leak into $i t$; residual impurities from the process recovering bred tritium; and hydrogen $\left({ }^{1} H\right)$ atoms resulting from spurious reactions in the plasma. Because of the need to separate isotopes of hydrogen, cryogenic distillation will likely be used. Fuel probably will be injected into the plasma in the form of solid DT pellets. (The alternative, neutral atom beams of $500 \mathrm{keV}$ energy, would require 3000 MWe--clearly out of the question for a 5000 MWt plant.) Pellet production facilities have not been designed, but could be accomplished by a cryogenic system used for distillation separation of hydrogen isotopes.

The method of fuel pellet injection is undefined and is an unsolved problem. The pellet velocity required to allow the fuel pellets to penetrate adequately into the plasma before they ablate away to nothing is unknown, due to uncertainties in pellet ablation rates. If pellets of radius 20 micrometers $(\mu \mathrm{m})$ can achieve adequate penetration, their injection at rates of $2 \times 10^{7}$ per second using present technology for electrostatic acceleration may be possible. Otherwise injection of $2 \mathrm{~mm}$ radius pellets at a rate of 20 per second may be necessary. (Each of the latter pellets would contain $0.35 \%$ of the reactor fuel charge of $1.3 \mathrm{~g}$ of tritium and $0.9 \mathrm{~g}$ of deuterium.) Electrostatic acceleration of such pellets to speeds between $10^{5}$ and $10^{7} \mathrm{~cm} / \mathrm{sec}$ nd would require millions of volts, and accelerators well beyond the state-of-the-art.

Blanket for the UWMAK-I Design - The blanket must breed tritium, convert neutron kinetic energy to heat, conduct the heat to a coolant, and provide a vacuum chamber for the plasma. Lithium is required for tritium breeding. It is also an efficient moderator having no adverse neutronic effects, and the metal has a high thermal conductivity. For these reasons liquid lithium metal is specified as a major constituent of the blanket, and it also functions as the primary coolant. The blanket structural material is Type $316 \mathrm{SS}$, primarily because a qualified metals industry exists that is capable of consistently producing this material with properties meeting established standards.

The blanket is located inside the toroidal field coils adjacent to the plasma (Figure 4). It is continuous except for gaps provided for plasma collection by the divertor. The blanket is $73.5 \mathrm{~cm}$ thick, and it is followed by a $77 \mathrm{~cm}$ thick shield that functions to protect the superconducting magnets from particles, radiation and heat escaping the blanket. Thermal insulation between the blanket, shield and magnets is provided by evacuated spaces separating them.

The innermost $20 \mathrm{~cm}$ of the blanket is thin ducting to direct the flow of the lithium coolantmoderator-fertile material (Figure 9). The vacuum wall is composed of the curved surfaces of the ducts, which are stressed in tension. This ducting is designed to be replaced every 2 years due to radiation embrittlement. The ducting is attached to a header plate by locking studs which mate with keyhole-shaped holes. Segments of ducting about a meter square are to be "buttoned" to the header plate with the locking studs, and then welded together to form a vacuumtight first wall. Replacement of the ducting will require that workers grind away the welds from inside the blanket module. The radioactivity of the structure will necessitate either the use of a mobile shielded facility, or a shielded tunnel over which the module can be shipped. Remote assembly/disassembly is not envisioned. 


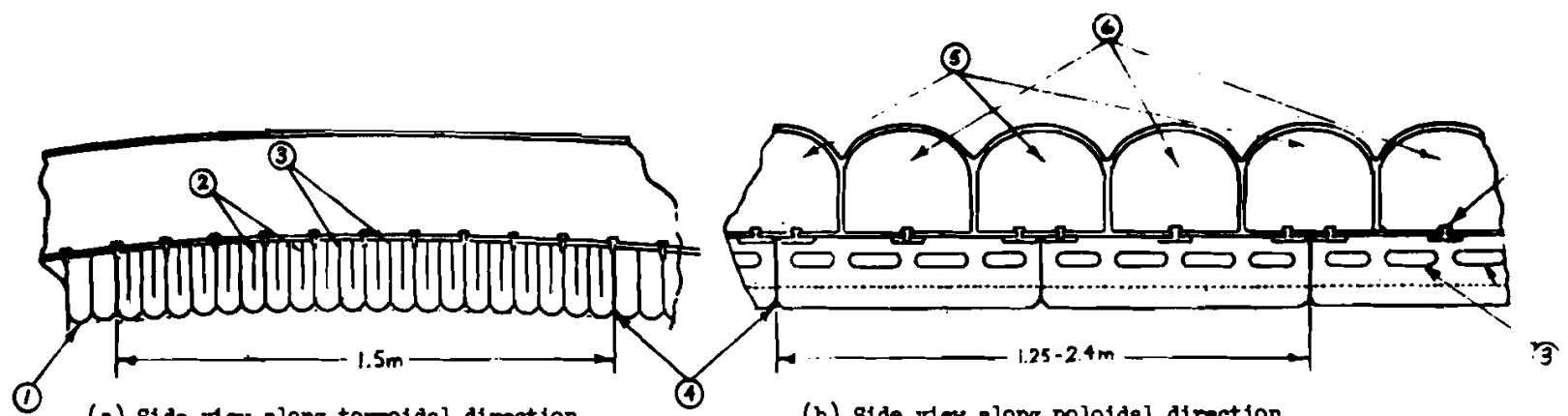

(a) Side riev along torroidal direction

(b) Side view along poloidal direction
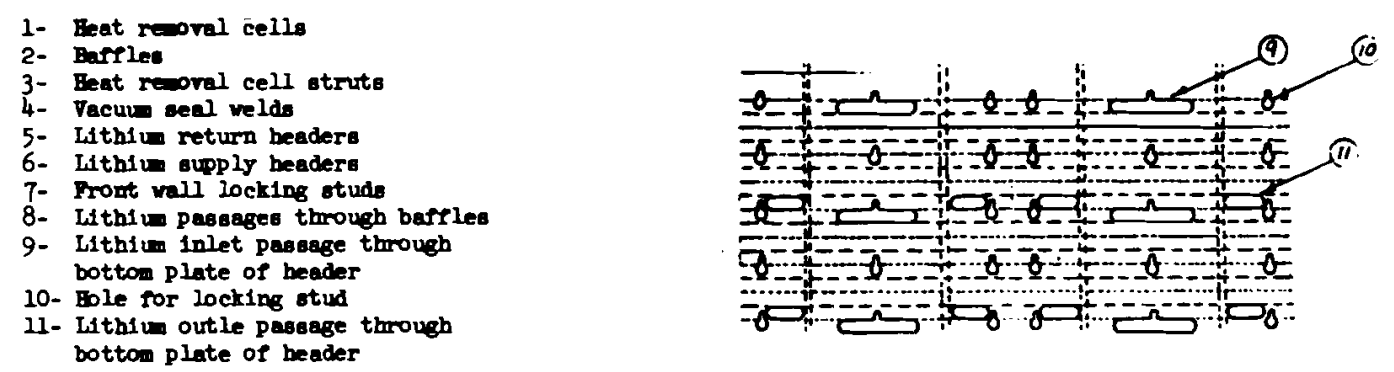

(c) View from outaide the blanket tovard the plasina with the top beader plate reoved

FIGURE 9 Views Showing the Proposed Method for Attaching the Front Wall to the Headers

The inner $20 \mathrm{~cm}$ duct region is followed by a $31 \mathrm{~cm}$ header region which supplies coolant to the ducts and removes it. These headers support the thin, replaceable ducting. The header region is followed by a massive neutron reflector region of Type $316 \mathrm{SS}$. This $22 \mathrm{~cm}$ thick region contains $17 \mathrm{~cm}$ of solid metal, plus two flow channels for liquid lithium coolant. Stainless steel was chosen for the reflector region instead of graphite because it provides a higher multiplication of incident neutron energy and a better attenuation of transmitted energy. Replacement of the header and reflector regions as a result of radiation-induced embrittlement is expected every 10 years.

The liquid lithium coolant flows through the blanket (Figure 4). It is piped radially through the shield into the blanket, where it spreads out, perpendicular to the plane of the figure, in toroidal headers. It then enters the middle region of the blanket, flowing in the plane of the figure (the poloidal direction) shown in Figure 9.

The lithium in the poloidal inlet headers enters the inner duct region through holes in the header plate. In the ducts the flow continues in the poloidal direction while baffles force it radially in and out, as is shown in Figure 10. After traversing the four U-shaped channels, the lithium exits through the header plate into an outlet header adjacent to the inlet header in which it entered. The poloidal direction of flow contínues in the outlet header, to a toroidal header which collects it for piping from the blanket. 


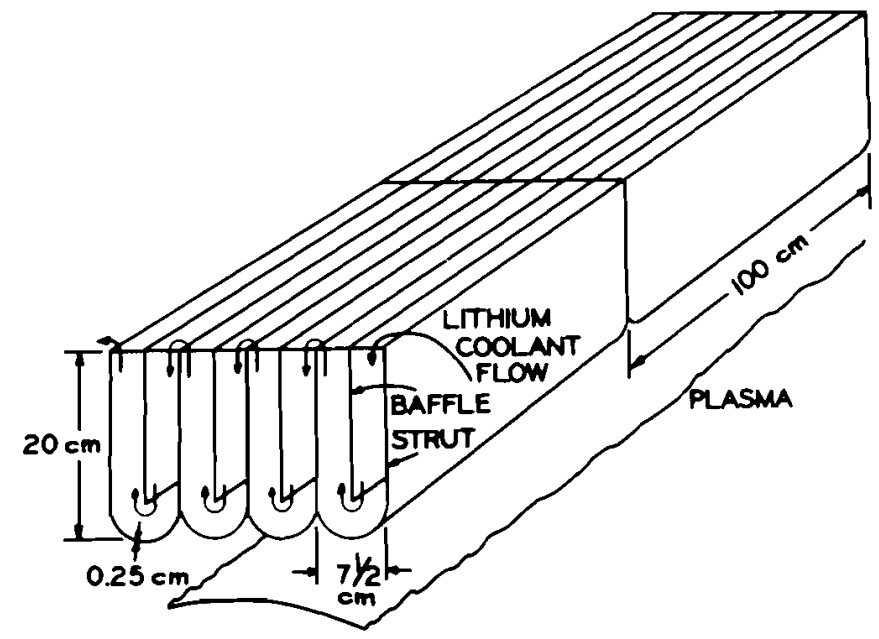

FIGURE 10 Isometric View of UWMAK-I Heat Removal Cells

The shield region which follows the blanket is composed of alternate layers of lead and $B_{4} C$, with stainless steel structural material. Channels are provided for helium gas coolant that is used to remove and dump the $1 \%$ of the reactor power which is deposited in the shield. Figure 11 is a schematic indication of major blanket and shield regions and material compositions.

The reactor is assembled from tweive $30^{\circ}$ modules, as shown in Figure 2 . The blanket for each module contains 520 metric tons of 316 SS and 120 metric tons of lithium. The shield for each module contains 170 metric tons of 316 SS, 135 metric tons of $B_{4} C$ and 1360 metric tons of lead.

Radiation induced embrittlement of Type 316 SS limits the lifetime of the blanket structure. At the first wall loading of $1.25 \mathrm{MW} / \mathrm{m}^{2}$, embrittlement is expected to require replacement of the inner $20 \mathrm{~cm}$ of blanket structure every 2 years, and additional replacement of the header and reflector regions of the blanket every 10 years.
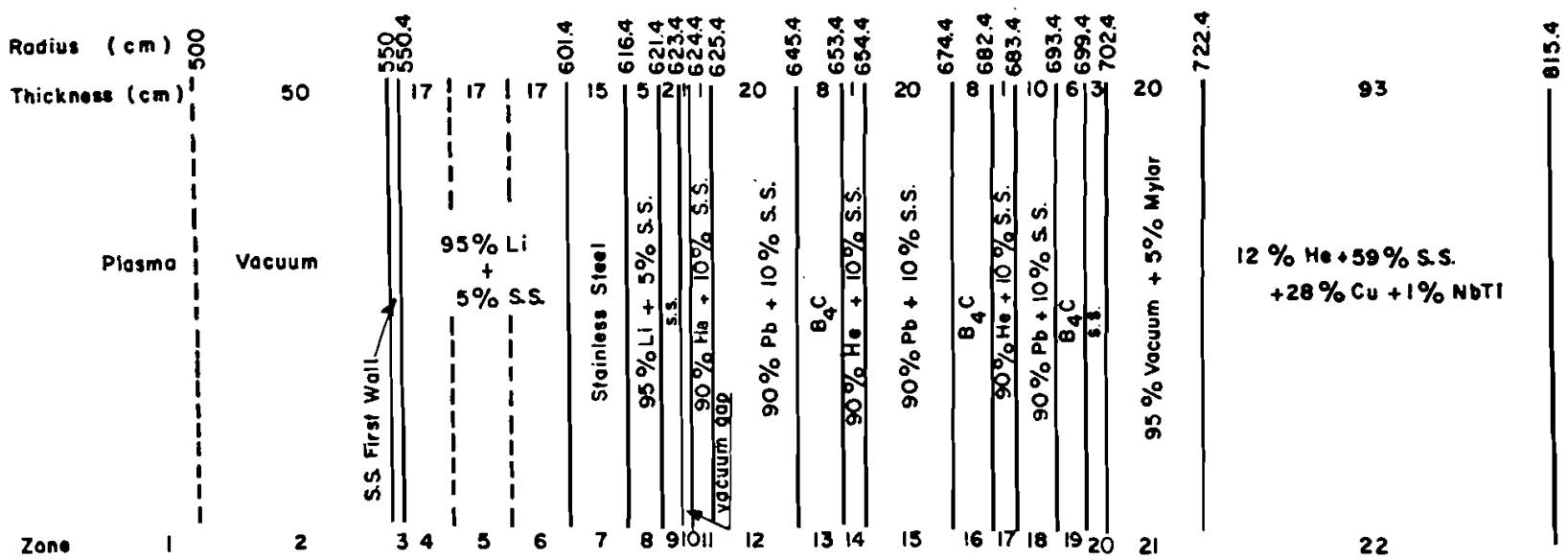

FIGURE 11 Schematic of UWMAK-I BTanket, Shield and Magnet 
It is planned to replace the inner regions of half of the blanket each year. This will yield 230 metric tons/yr of Type 316 SS having an activity at shutdown of about $1 \times 10^{9} \mathrm{Ci}$, due primarily to the decay of ${ }^{55} \mathrm{Fe},{ }^{58} \mathrm{Co},{ }^{54} \mathrm{Mn},{ }^{57} \mathrm{Co},{ }^{60} \mathrm{Co},{ }^{57} \mathrm{Ni},{ }^{63} \mathrm{Ni}$ and ${ }^{49} \mathrm{~V}$. This radioactivity will produce about 10 MW of afterheat, which will decrease to about 1 MW after 1 year. This material will be compacted to a volume of about $31 \mathrm{~m}^{3}$.

Replacement of the entire blanket after 10 years of operation will yield about 7300 metric tons of Type 316 SS. The radioactivity of this material will be about $5 \times 10^{9} \mathrm{Ci}$ and the afterheat will be about $32 \mathrm{MW}$. Compaction of the material external to the inner, regularly replaced, region may be difficult due to the thickness of the elements.

Removal of impurities from the lithium primary coolant will yield $2750 \mathrm{~kg} / \mathrm{yr}$ of material corroded and neutron-sputtered from Type 316 SS structure. The activity of this material will be due to the isotopes produced in the structure, and if the removal is not selective an activity of $4 \times 10^{6} \mathrm{Ci}$ is expected.

Heat Transfer System for the UWMAK-I Design - Liquid lithium is the primary coolant. It carries the heat which it absorbs in the blanket to external heat exchangers where it is transferred to liquid sodium intermediate coolant. The sodium intermediate coolant carries the heat to steam generators where it is used to raise high pressure steam to drive the turbine-generators

(Figure 12).

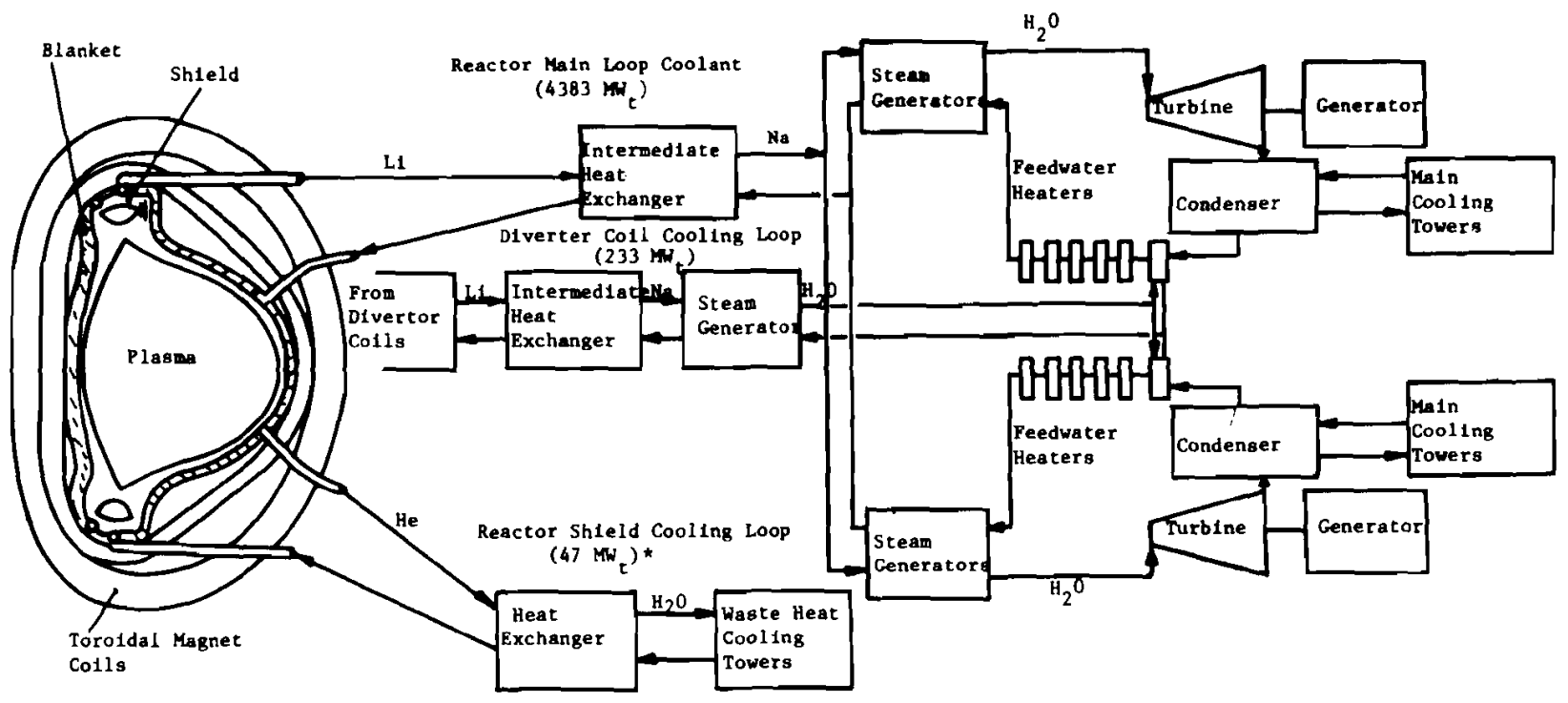

* T1me averaged values

FIGURE 12 Schematic of UWMAK-I Plant Design 
The liquid lithium primary coolant also functions as a neutron moderator and a fertile material for tritium breeding; consequently, large quantities are contained within the blanket. The design requires $1.7 \times 10^{6} \mathrm{~kg}$ of lithium for primary coolant and the lithium contained in the blanket. This is circulated with a total mass flow rate of $3.2 \times 10^{7} \mathrm{~kg} / \mathrm{hr}$.

An independent coolant loop is specified for each of the 12 modules that make up the reactor. This limits the amount of tritium contained in the lithium that might be available for leakage in the event of a catastrophic accident in any one of the primary coolant loops. It also limits the amount of piping which must be disturbed during change out of a module.

The liquid lithium flow paths through the blanket are designed to minimize magnetohydrodynamic pumping losses due to flow of the electrically conducting coolant in the magnetic field of the reactor. The lithium enters the reactor at a pressure of $47 \mathrm{~kg} / \mathrm{cm}^{2}$ and exits at a pressure of $3 \mathrm{~kg} / \mathrm{cm}^{2}$. Most of the pressure drop occurs in the inlet/outlet piping and header regions.

The lithium enters the reactor at a temperature of $359^{\circ} \mathrm{C}$ and leaves at $489^{\circ} \mathrm{C}$. The need to keep stainless steel structure in contact with the lithium below $500^{\circ} \mathrm{C}$ is a primary design constraint. Most of the temperature increase in the lithium occurs while it traverses the U-shaped flow channels near the first wall.

Pressure and temperature changes of the lithium while passing through the reactor are indicated in Figures 13 and 14, which are from Volume I of the study. ${ }^{(3)}$ The numerical values shown on the figures disagree with those quoted above from Volume II, due to a design modification between publications. Nevertheless, the trends are clear.

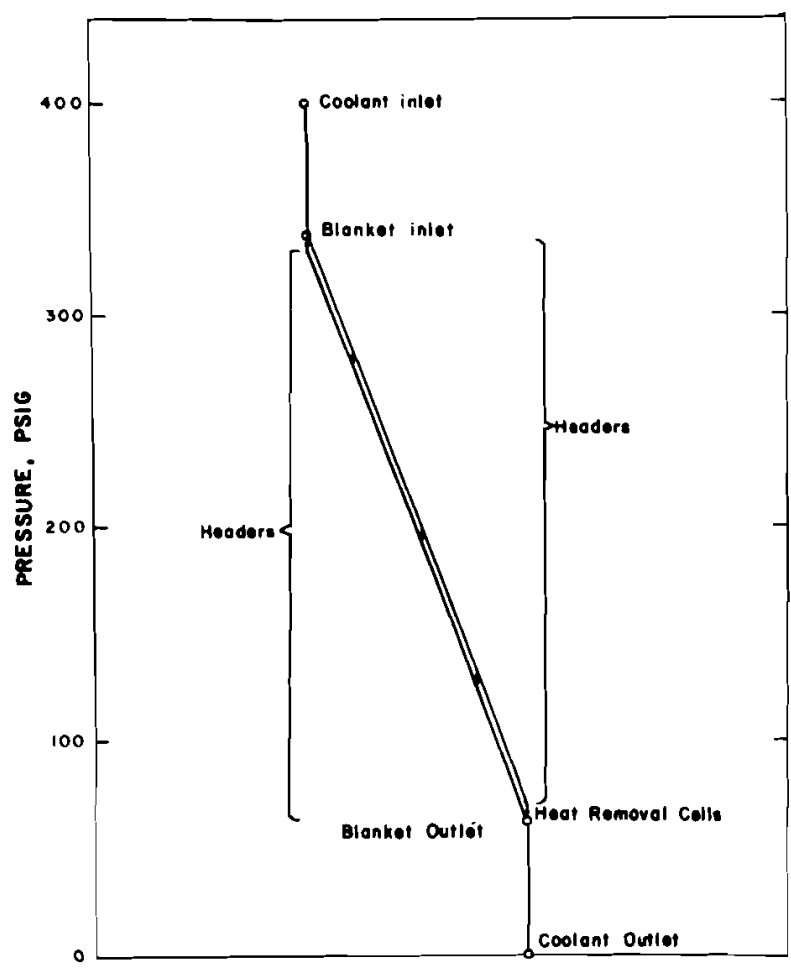

FIGURE 13 Coolant Pressure Distribution in UWMAK-I 


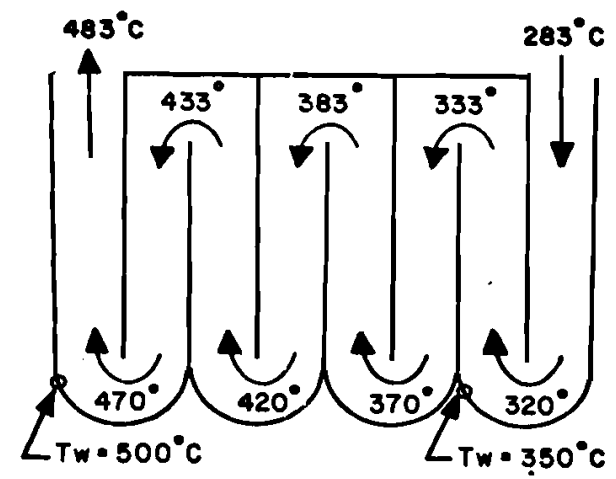

FIGURE 14 Bulk and Maximum Coolant Temperatures in a Radial Flow Ce11 in UWMAK-I

Despite the temperature limitations placed upon stainless steel structure in contact with liquid lithium coolant, it is estimated that about $2500 \mathrm{~kg} / \mathrm{yr}$ of corrosion products and $250 \mathrm{~kg} / \mathrm{yr}$ of sputtering products must be removed from the lithium coolant. This is achieved on a continuous basis by diverting $1 \%$ of the primary coolant hot leg flow through a cleanup system where it is heated to $645^{\circ} \mathrm{C}$, passed over about $10^{5} \mathrm{~kg}$ of thin zirconium foil to getter impurities, and returned via a regenerative heat exchanger.

Because of the inventory of tritium and activated corrosion products expected in the lithium primary coolant, and the possibility of violent chemical reaction between liquid metal and steam coolants, the primary coolant is physically separated from the steam system by an intermediate coolant loop. Heat is exchanged to sodium intermediate coolant in 12 shell-and-tube intermediate heat exchangers (IHXs) whose design is derived from LMFBR studies. (Design modification was necessary because the LMFBR design was made for sodium which has a heat capacity of 2.7 times that of lithium.) Figure 15 shows one of the IHXs, each of which contains 4982 tubes of Type 304 SS (slightly more chrome and less nickel than Type 376 SS, and less permeable to tritium). The surface area of each IHX is $1.6 \times 10^{3} \mathrm{~m}$. After passing through the IHX about $10 \%$ of the lithium flow is diverted to the tritium extraction beds.

Liquid metal pumps using LMFBR technology are used to return the lithium primary coolant from the IHXs to the reactor inlet at the design pressure.

Sodium intermediate coolant enters the tube side of the IHXs at a temperature of $336^{\circ} \mathrm{C}$ and a pressure of $4.9 \mathrm{~kg} / \mathrm{cm}^{2}$; it exits at $456^{\circ} \mathrm{C}$ and $2.5 \mathrm{~kg} / \mathrm{cm}^{2}$. The total sodium flow rate through all 12 loops is $1.2 \times 10^{8} \mathrm{~kg} / \mathrm{hr}$.

The intermediate coolant loops contain a total of $1.8 \times 10^{7} \mathrm{~kg}$ of sodium. This exceeds the amount necessary to simply transmit the heat from the reactor because hot sodium is accumulated during the reactor burn, for subsequent steam generation during reactor recharge periods. About $7 \%$ of the sodium flow is diverted to an insulated holding tank for this function. An additional $1 \%$ of the flow is diverted through a cleanup system for the removal of oxygen and corrosion products. 


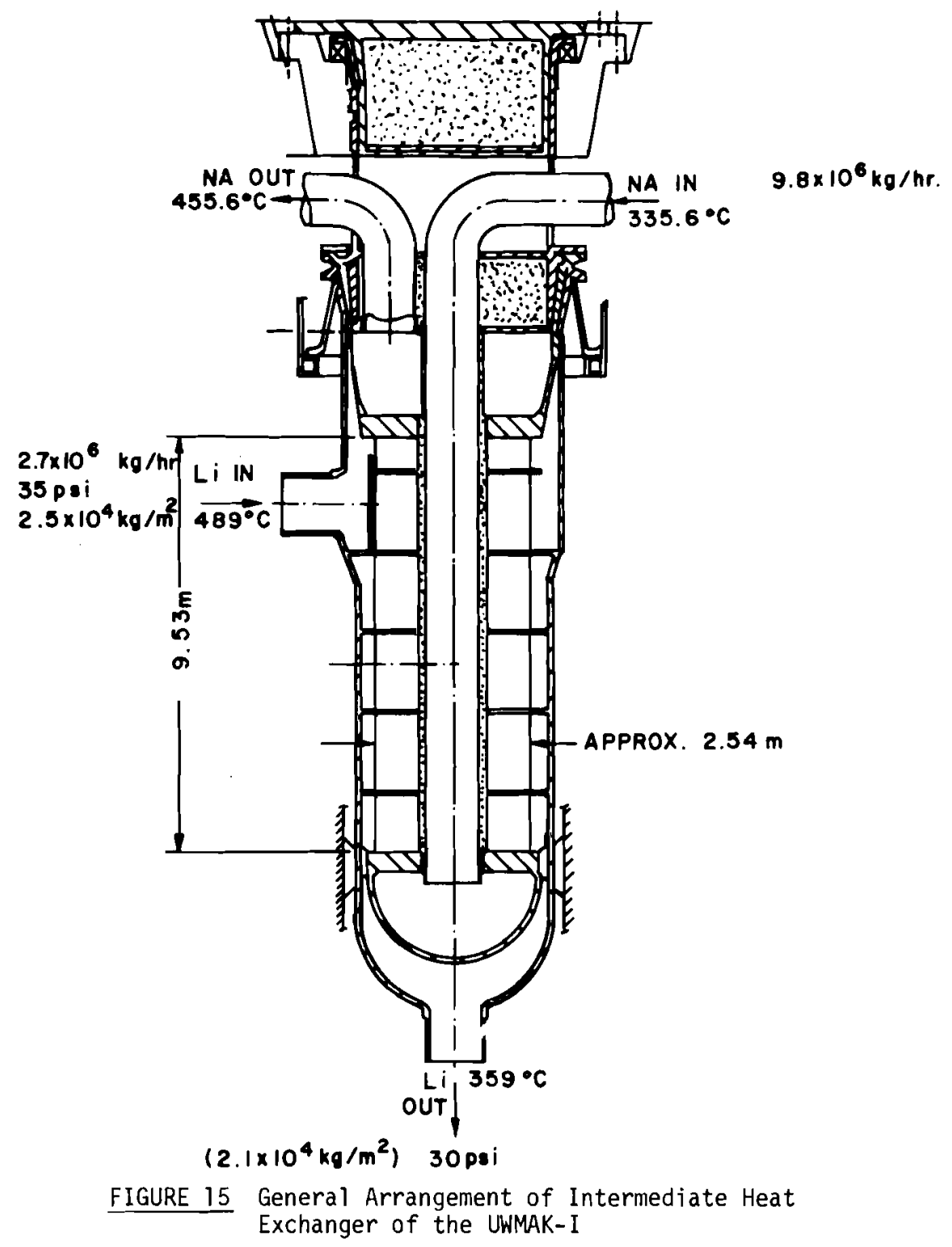

Most of the hot sodium emerging from the IHXs is circulated through steam generators and returned by LMFBR-type liquid metal pumps. About $10 \%$ of the return flow is diverted to tritium extraction beds similar to those in the lithium system.

Steam generators have been designed for this reactor utilizing a proprietary combination of the latest technology. The steam generators are of once-through design. The steam is generated in vertical tubes of Inconel-600 which fit into grooves on the sides of horizontal sodium ducts made of Croloy 2-1/4 steel. Thus the sodium and the steam are in separate, individual tubes. A gap of $0.025 \mathrm{~mm}$ is maintained between the sodium ducts and the steam tubes, and this gap is filled with helium containing a trace of oxygen to scavenge tritium permeating from the sodium coolant. Figure 16 indicates the overall layout and dimensions of the steam generators. 


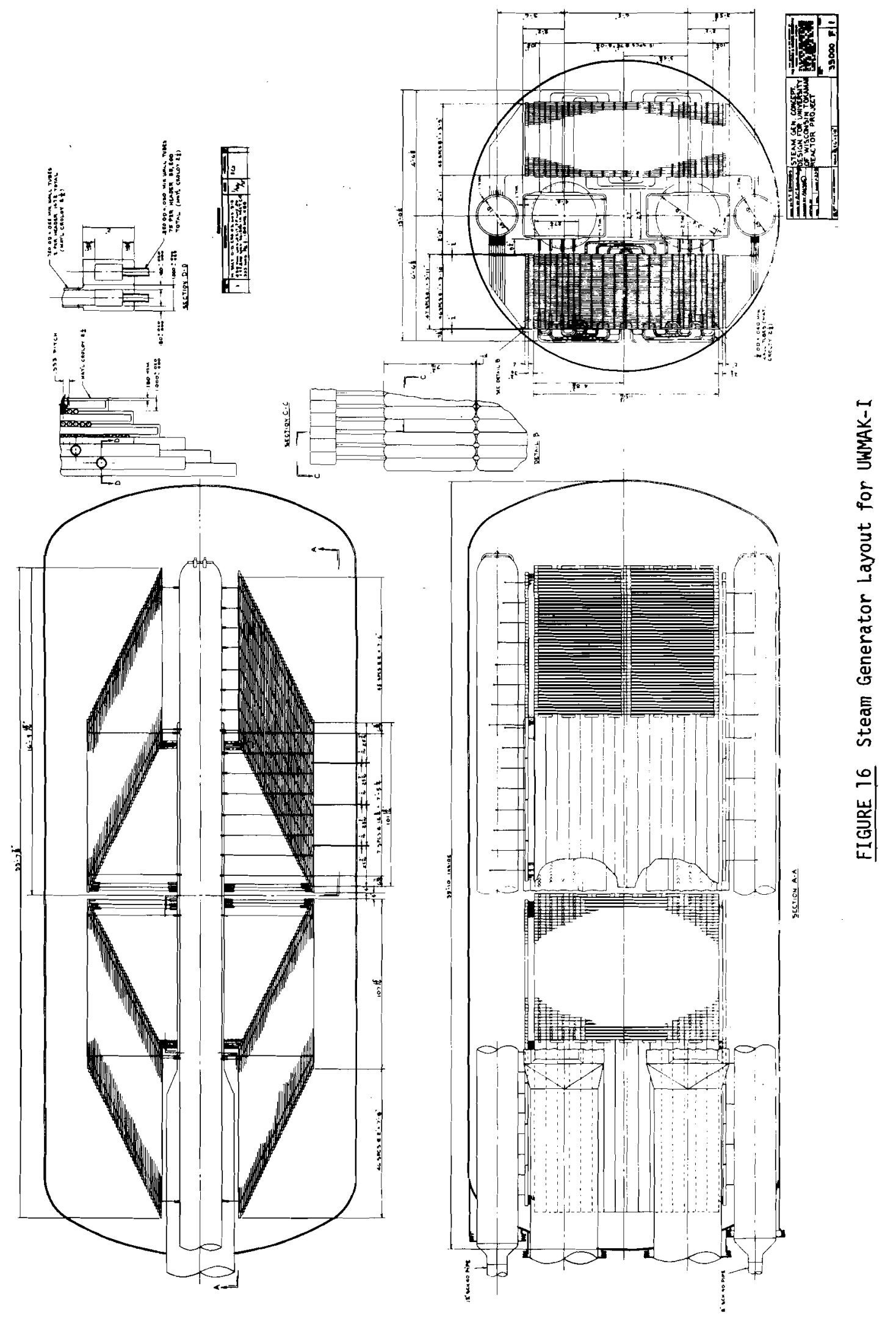


Water enters the steam generators at a temperature of $218^{\circ} \mathrm{C}$ and a pressure of $148 \mathrm{~kg} / \mathrm{cm}^{2}$; it leaves as steam at $404^{\circ} \mathrm{C}$ and $140 \mathrm{~kg} / \mathrm{cm}^{2}$. The total steam flow from all 12 steam generators is $7.5 \times 10^{6} \mathrm{~kg} / \mathrm{hr}$.

Electricity Generation System for the UWMAK-I Design - Electricity is generated by two identical tandem compound turbine arrangements, each of which drives an $1800 \mathrm{rpm}, 26 \mathrm{kV}$ generator. Superheated steam flows from the steam generators at a rate of $7.5 \times 10^{6} \mathrm{~kg} / \mathrm{hr}$. The flow is divided equally and sent to the turbine-generator units. In each unit the steam passes through one double flow high pressure (HP) turbine, a moisture separator, two stages of reheat, and a quadruple flow low pressure (LP) turbine employing two stages of moisture removal (Figure 17).

The reheat stages between the HP and LP turbines are not part of the steam generators. As can be seen in the figure, the first reheat is done by extraction steam from the HP turbine, and the second reheat is done by throttle steam directly from the steam generators. Additional steam is extracted from the main flow through the turbines for heating feedwater for the steam generator, and to spin the turbines driving the pumps which supply feedwater to the steam generators.

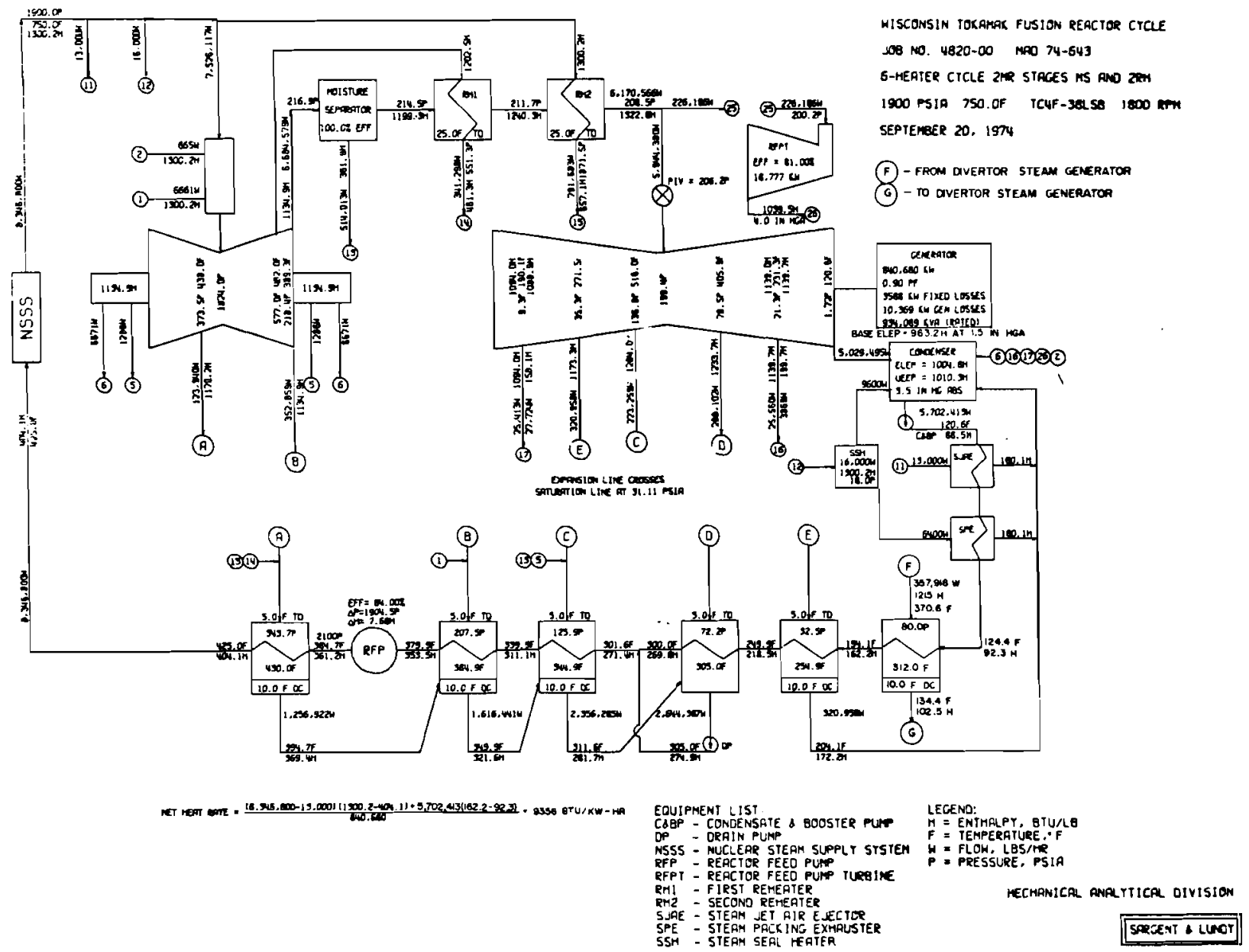

FIGURE 17 Flow Diagram for One of the Turdine-Generators in UWMAK-I 
Most of the steam $\left(4.6 \times 10^{6} \mathrm{~kg} / \mathrm{hr}\right)$ passes through the turbines and is condensed at a pressure of $1.7 \mathrm{psia}$ and a temperature of $49^{\circ} \mathrm{C}$. The condensers are not described. They will require a total flow of $1.9 \times 10^{8} \mathrm{~kg} / \mathrm{hr}$ of cooling water to condense the steam.

Each of the two generators produces 841 MWe. Of the gross plant electrical output (1681 MWe) about 12\% (208 MWe) is used to operate auxiliary plant equipment. Major uses are as follows: liquid metal pumps, $110 \mathrm{MW}$; water system pumps, $37 \mathrm{MW}$; miscellaneous 1 ighting, heating, $19 \mathrm{MW}$; cooling tower and exhaust fans, $14 \mathrm{MW}$; heaters for the 1 ithium and sodium systems, $13 \mathrm{MW}$; other, $15 \mathrm{MW}$. The net plant output is thus 1473 MWe, produced from 4663 MWt. The gross thermal efficiency of generation is $36 \%$, and the net plant efficiency is $32 \%$. The net heat rate is $9356 \mathrm{Btu} / \mathrm{kWh}$.

Four mechanical draft wet cooling towers are used to dissipate 3055 MWt of waste heat from the condensers to the atmosphere. Normal operation will require a water makeup of $6 \times 10^{6} \mathrm{~kg} / \mathrm{hr}$ due to losses such as drift, evaporation, and blowdown. A reservoir beneath the tower basins contains $2 \times 10^{6} \mathrm{~kg}$ of water, enough for emergency cooling of the reactor in shutdown condition for 30 days.

Spent Plasma Collection System for the UWMAK-I Design - The collection of burned and unburned fuel escaping from the plasma takes place in the divertor. Ninety percent of the ions escaping from the plasma are guided to the divertor by magnetic fields. The remainder impact the plasma chamber wall, are neutralized there, and are reemitted as neutral gas atoms. These are eventually drawn into the divertor chambers by vacuum pumps. Therefore, the divertor collects

$7.7 \mathrm{~kg} /$ day of tritium, $5.1 \mathrm{~kg} /$ day of deuterium and $0.9 \mathrm{~kg} /$ day of helium.

The two divertor collection chambers on top of the torus are shown in Figure 18; two more are located similarly on the bottom. Each of the chambers will have exposed collection plates, down which a sheet of liquid lithium flows. It is expected that $96 \%$ of the deuterium and tritium ions and neutral atoms that enter the divertor will be trapped in the lithium, due to the affinity of liquid lithium for hydrogen isotopes. A trapping rate per day of $7.4 \mathrm{~kg}$ of tritium and $4.9 \mathrm{~kg}$ of deuterium is therefore expected. A schematic of a plate and its lithium supply is shown in Figure 18. The materials trapped in the lithium are to be removed by a system similar to that used to recover tritium bred in the lithium primary coolant.

The divertor vacuum system collects the $0.3 \mathrm{~kg} /$ day of tritium and $0.2 \mathrm{~kg} /$ day of deuterium which escape trapping in the lithium, and also $0.9 \mathrm{~kg} /$ day of helium which is not expected to be trapped in the $1 i$ thium. Vacuum ducts (Figure 4) connect the divertor chambers of each of the blanket modules to plenna outside the magnets. Twelve pumps, each with $75 \mathrm{~cm}$ diameter orifices serve each plenum. Four of the pumps are mercury diffusion pumps having freon and liquid-nitrogen cooled traps. The remainder are cryopumps which use liquid-helium cooled charcoal absorption, with a liquid-nitrogen cooled shield. The cryopumps are operated in shifts, with half of them degassing while the other half pumps. Thus 96 diffusion pumps and 96 cryopumps are always in operation, with 96 cryopumps degassing. A total pumping speed of $2.6 \times 10^{8} 1 /$ second is expected. 


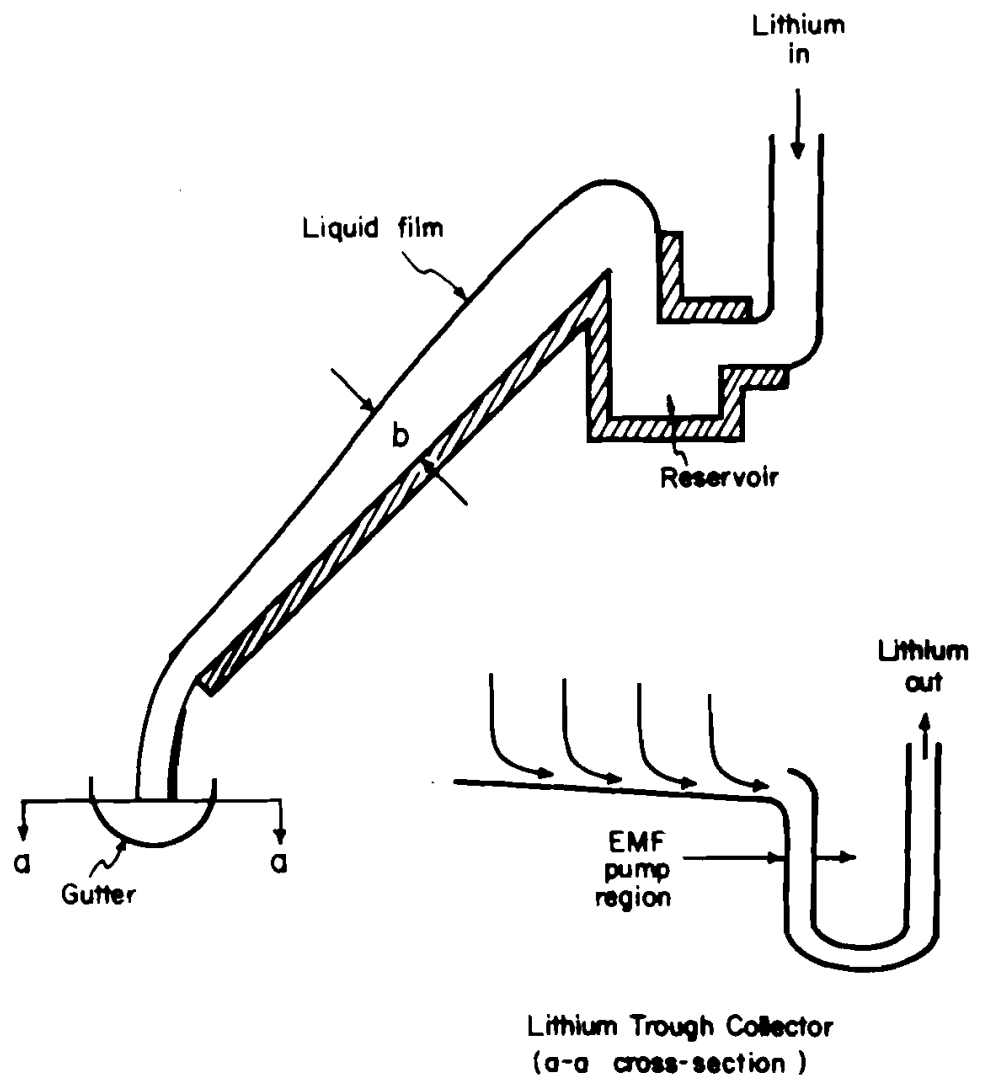

FIGURE 18 Schematic of One Divertor Liquid Lithium Collector Plate in UWMAK-I

The cryopumps are operated only at pressures below $2.5 \times 10^{-4}$ torr. This occurs during the final evacuation after ignition, and during the thermonuclear burn. In between burn cycles, following plasma quenching, the plasma chamber is evacuated to $10^{-5}$ torr by the diffusion pumps and lithium trapping surfaces. Following "recocking" of the transformer coils, and a final 10 second pump out, D-T gas is injected to a pressure of $2.3 \times 10^{-3}$ torr. Then, after the reactor startup yields ignition, the divertor is pumped to $2 \times 10^{-5}$ torr and the cryopumps are valued on.

Each set of one diffusion pump and two cryogenic pumps is backed by two Roots blower pumps in series, followed by a mechanical forepump. The forepump exhaust gas is compressed in cylinders for subsequent processing.

The holdup of tritium in pump oil is minimized through the use of mercury diffusion pumps and roots blowers (which require oil only for gears and bearings, but not the rotors). However, recovery of tritium from oil in the large forepumps is an unsolved problem.

Energetic ions deposit energy in the $1 \mathrm{ithium}$ trapping layer at the rate of $237 \mathrm{MWt}$. The lithium flow rate is sufficiently high to limit its temperature to $325^{\circ} \mathrm{C}$, so that its vapor pressure remains below the $10^{-5}$ torr to be maintained by the vacuum system. Heat is removed by 
circulating the lithium from the reactor, heat exchange to a sodium intermediate coolant, and steam generation. However, because of the low temperature steam generated $\left(226^{\circ} \mathrm{C}\right)$ the steam is used only for feedwater heating.

Bred Tritium Recovery System for the UWMAK-I Design - The breeding ratio of tritium in the blanket lithium is 1.49 . The $1.03 \mathrm{~kg}$ /day of tritium which is bred is recovered by a yttrium getter which processes a portion of the lithium primary coolant stream. This method is also used to recover spent deuterium and tritium fuel trapped in flowing lithium in the divertor (see spent plasma collection) and to recover tritium which has permeated into the sodium intermediate coolant. The locations of tritium recovery beds are indicated on the coolant flow schematic of Figure 19.

The yttrium getter receives about $5 \%$ of the flow from the low temperature side of the primary coolant loop. (Operation at low temperature maximizes tritium accumulation in the getter, in contrast to the lithium clean-up getter which operates off the high temperature leg to minimize tritium accumulation.) The lithium is passed over $90 \mathrm{~kg}$ of $0.1 \mathrm{~mm}$ yttrium foil in one of two beds. The beds are interchanged and regenerated daily by draining and heating. Evolved tritium is pumped off and collected. The average bed inventory of tritium is $1 \mathrm{~kg}$, a 1 day accumulation. Spent fuel trapped in lithium in the divertor is recovered in one of four yttrium beds similar to those described. Each bed contains $350 \mathrm{~kg}$ of foil and operates 6 hours per day before regeneration. These beds recover $7.4 \mathrm{~kg} /$ day of tritium and $4.9 \mathrm{~kg} /$ day of deuterium. The average total inventory of these beds is assumed to be a half day accumulation of $3.5 \mathrm{~kg}$ of tritium.

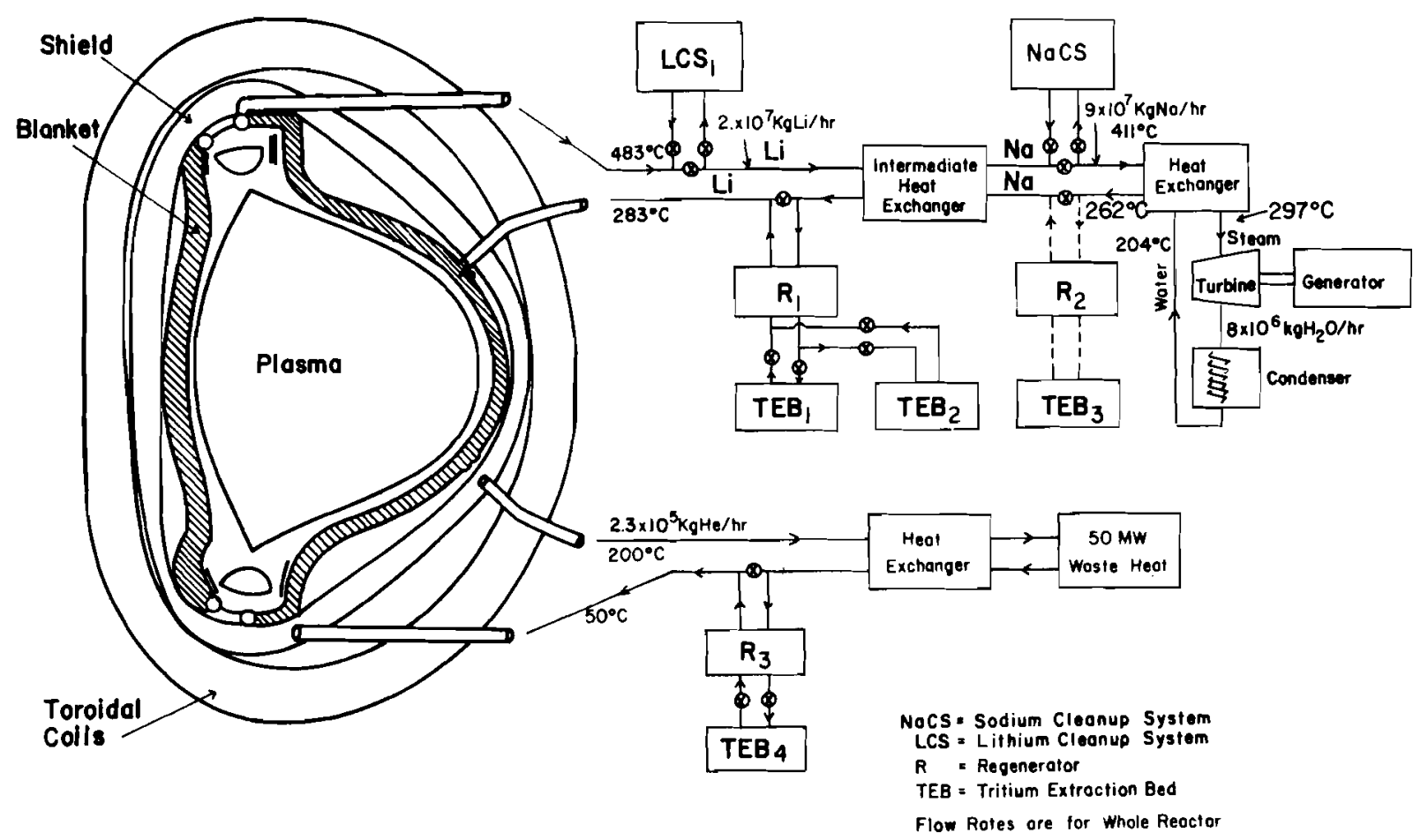

FIGURE 19 Coolant Loops for UWMAK-I 
Tritium permeating into the sodium intermediate coolant is recovered in one of two beds containing $45 \mathrm{~kg}$ of foil. These beds are to function only in the event of excessive tritium leakage from the lithium, as the tritium concentration expected in the sodium $\left(<10^{-4} \mathrm{ppm}\right)$ is too low for feasible recovery.

It has been estimated that the beds can hold the concentration of tritium to $5 \mathrm{ppm}$ and $0.24 \mathrm{ppm}$ in the primary coolant and in the divertor lithium stream. The concentration difference is due primarily to the operating temperatures, assumed to be $283^{\circ} \mathrm{C}$ and $200^{\circ} \mathrm{C}$. However, a design change between publication of Volumes $I$ and II of the design study ${ }^{(3)}$ raised the cold leg temperature of the primary coolant to $359^{\circ} \mathrm{C}$. The tritium concentration achievable at this temperature has not been estimated. The tritium inventory of the plant is estimated to be $23.5 \mathrm{~kg}$ (Table 8). Tritium flows in the plant are indicated in figure 20.

\begin{tabular}{|c|c|}
\hline & $\begin{array}{l}\text { Tritium, } \\
\text { Kilograms }\end{array}$ \\
\hline Lithium primary coolant & 8.7 \\
\hline Lithium trapping stream (divertor) & 0.008 \\
\hline Primary coolant recovery beds & 1.0 \\
\hline Divertor lithium recovery beds & 3.5 \\
\hline Divertor cryopumps & 0.3 \\
\hline Plant active inventory & 13.5 \\
\hline Storage & 10.0 \\
\hline Total plant tritium inventory & $\overline{23.5}$ \\
\hline
\end{tabular}

a. The tritium stored is 14.5 times the daily consumption rate, and 1.2 times the daily injection rate.

Containment Building for the UWMAK-I Design - Two levels of containment are provided within the reactor building (Figure 2). Both primary and secondary containments are designed to criteria generally similar to those for current nuclear plant design. Structural loadings, temperatures and pressures resulting from both operating and accident conditions are considered in the design, as well as environmental and special loadings due to the effects of earthquakes, flooding, missiles and pipe breakage.

The primary containment completely encloses the reactor in a steel lined concrete cell designed to operate at a (vacuum) pressure of 1 torr. Evacuation of this cell improves the ability to collect tritium leaking from the reactor, reduces the in-leakage of air into the reactor vacuum vessel, and eliminates the possibility of a liquid metal lithium fire in the event of pipe breakage.

The primary containment cell is designed for a maximum negative pressure of 15 psig (vacuum) and a maximum positive pressure of 10 psig (1ithium fire). The containment cell is composed of a steel cylinder $61.4 \mathrm{~m}$ in diameter resting on a reinforced concrete mat (which also supports the 


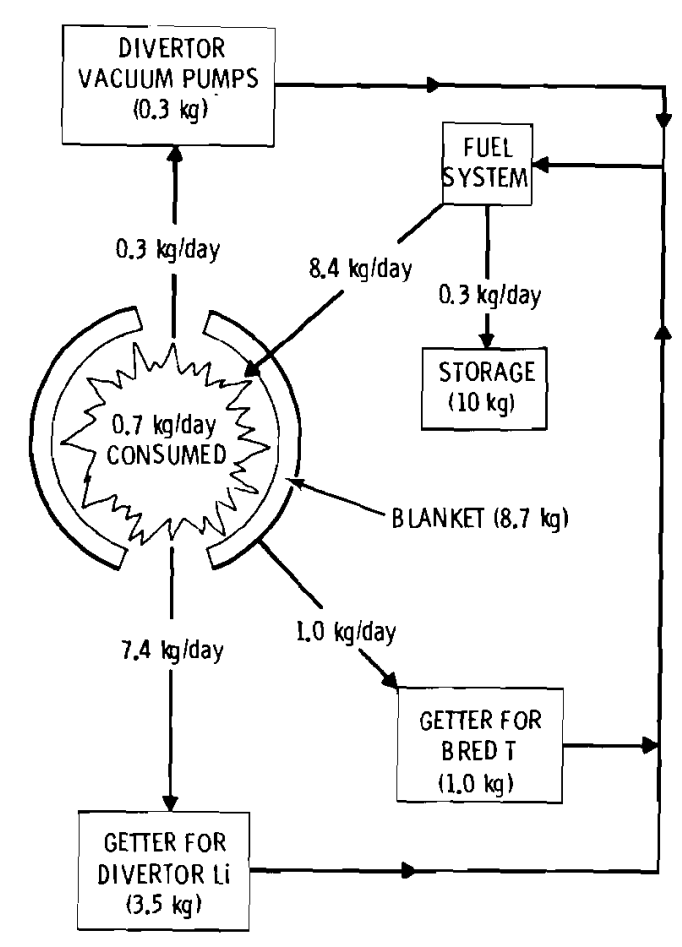

FIGURE 20 Tritium Flow and Inventory Schematic for UWMAK-I

secondary containment) and a toroidal roof of reinforced concrete lined with steel plate for leak tightness. The steel cylinder contains a hatch to allow the removal of a complete torusmagnet module, and is mounted on a track which allows it to revolve. The roof is supported by one central and 12 peripheral columns.

The secondary containment is a right circular cylinder of steel-lined, reinforced concrete that surrounds the first three floors of the reactor building. It contains: the ma in floor used for moving reactor segments for servicing; the second floor containing lithium processing equipment and the intermediate heat exchangers; and the third floor containing sodium processing equipment and the steam generators. (Heating, ventilating and air conditioning equipment are located on the top floor of the reactor building above the ceiling of the secondary containment.) An inert gas atmosphere is maintained around piping carrying the liquid lithium primary coolant, including the entire lithium processing floor. This is to prevent a liquid metal fire in the event of leakage or a pipe break.

The secondary containment is designed for a maximum negative pressure of -8 psig and a maximum positive pressure of $10 \mathrm{psig}$. It is about $120 \mathrm{~m}$ in diameter with $2.4 \mathrm{~m}$ thick walls on the main floor. The wall thickness on the second and third floors are $1.2 \mathrm{~m}$ and $0.6 \mathrm{~m}$, respectively.

Three hot cells project from the secondary containment cylinder at $120^{\circ}$ intervals. They are constructed of steel-1ined, reinforced concrete $2.4 \mathrm{~m}$ thick, and form part of the secondary containment. 


\subsubsection{Brookhaven Blanket (BNL) for UWMAK-I Tokamak}

Summary Description - The BNL blanket power plant ${ }^{(5)}$ for the UWMAK-I Tokamak produces 1605 MWe of net electrical power from a thermal energy release of $5000 \mathrm{MWt}$. The generation cycle coincides with the thermonuclear burn cycle, which is 96.5 minutes long and includes a 6.5 minute shutdown for refueling. A section view of the reactor and containment building is shown in Figure 21 .

The reactor blanket is composed of solid materials that are cooled by circulating helium. Aluminum is used for the blanket structure, to minimize activation and residual radioactivity. A separate pressurized water cooling system maintains the temperature of the aluminum structure well below that of the blanket contents, to maintain structural integrity without restricting power plant thermal efficiency to the low values achievable at the low temperatures required by the structure.

Major power plant systems are identified and their functional relations are indicated in Figure 22.

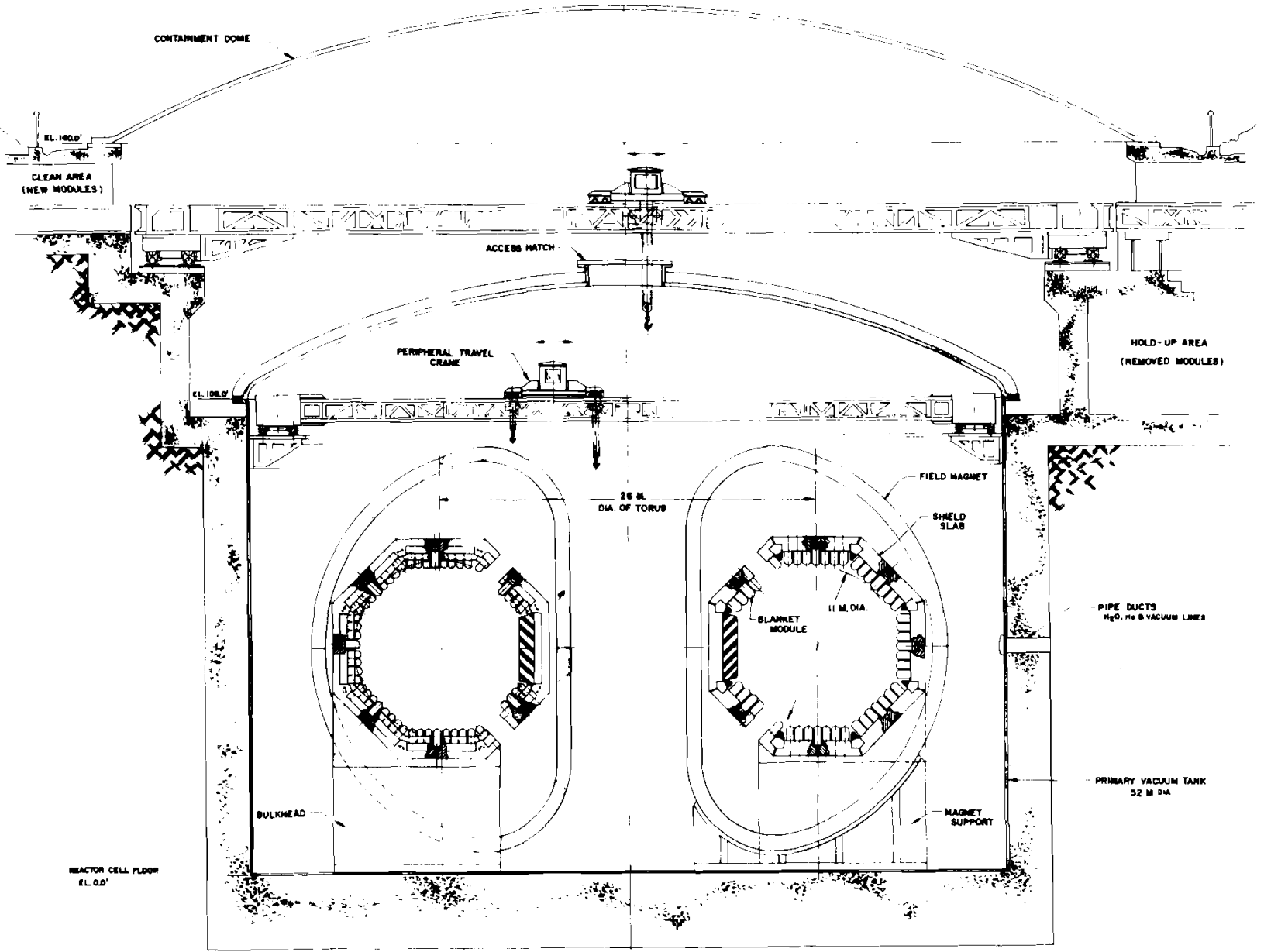

FIGURE 21 Reactor and Containment Building for UWMAK-I 


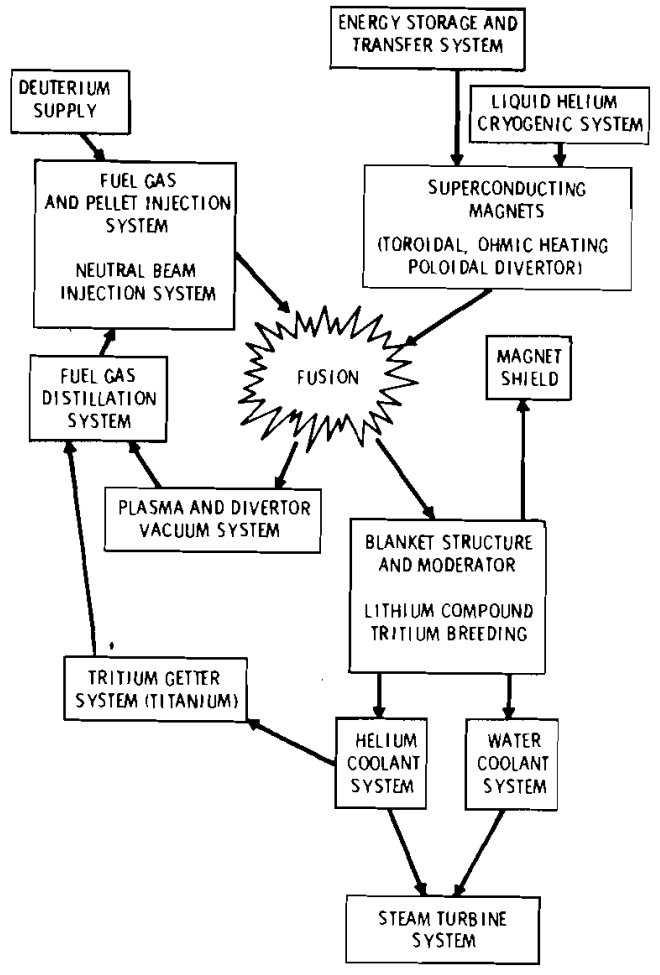

FIGURE 22 Functional Relations Between Systems of the BNL Blanket for the UWMAK-I Tokamak

The containment building encloses an evacuated tank inside of which the reactor is located. Water and helium primary coolants are piped from the vacuum tank to an external containment building for steam generation.

The reactor itself is an adaptation of the UWMAK-I reactor. Plasma confinement (magnets and plasma chamber), heating (plasma current and neutral beam injectors), and fueling (cryogenic pellet injection) are adopted unchanged from the UWMAK-I design, and are not discussed in this description. Due to the blanket and cooling system modifications, however, different spent plasma collection and bred tritium recovery systems are employed. Steam system conditions also differ.

The blanket which collects the fusion energy and which breeds tritium is located inside the magnet coils, adjacent to the plasma. It is $91 \mathrm{~cm}$ thick, and is followed by a $110 \mathrm{~cm}$ thick shield to reduce particle and radiation heating of the superconducting magnets. Thermal insulation of the cryogenic magnets is provided by evacuation of the reactor tank.

The blanket is constructed of type 6061 aluminum alloy. It contains beryllium for neutron multiplication, and graphite neutron moderator. Tritium is bred in solid LiAl and $\mathrm{LiAlO}_{2}$.

The blanket is composed of 7200 cylindrical modules whose domed ends face the plasma. Section views of a typical module are shown in Figure 23. Water coolant flows through passages within the module shell. Low temperature helium entering the modules follows the walls to the domed ends, then flows back through the high temperature module interior, which is insulated from the cylindrical walls. The toroidal blanket is composed of 24 sectors of $15^{\circ}$ each. 


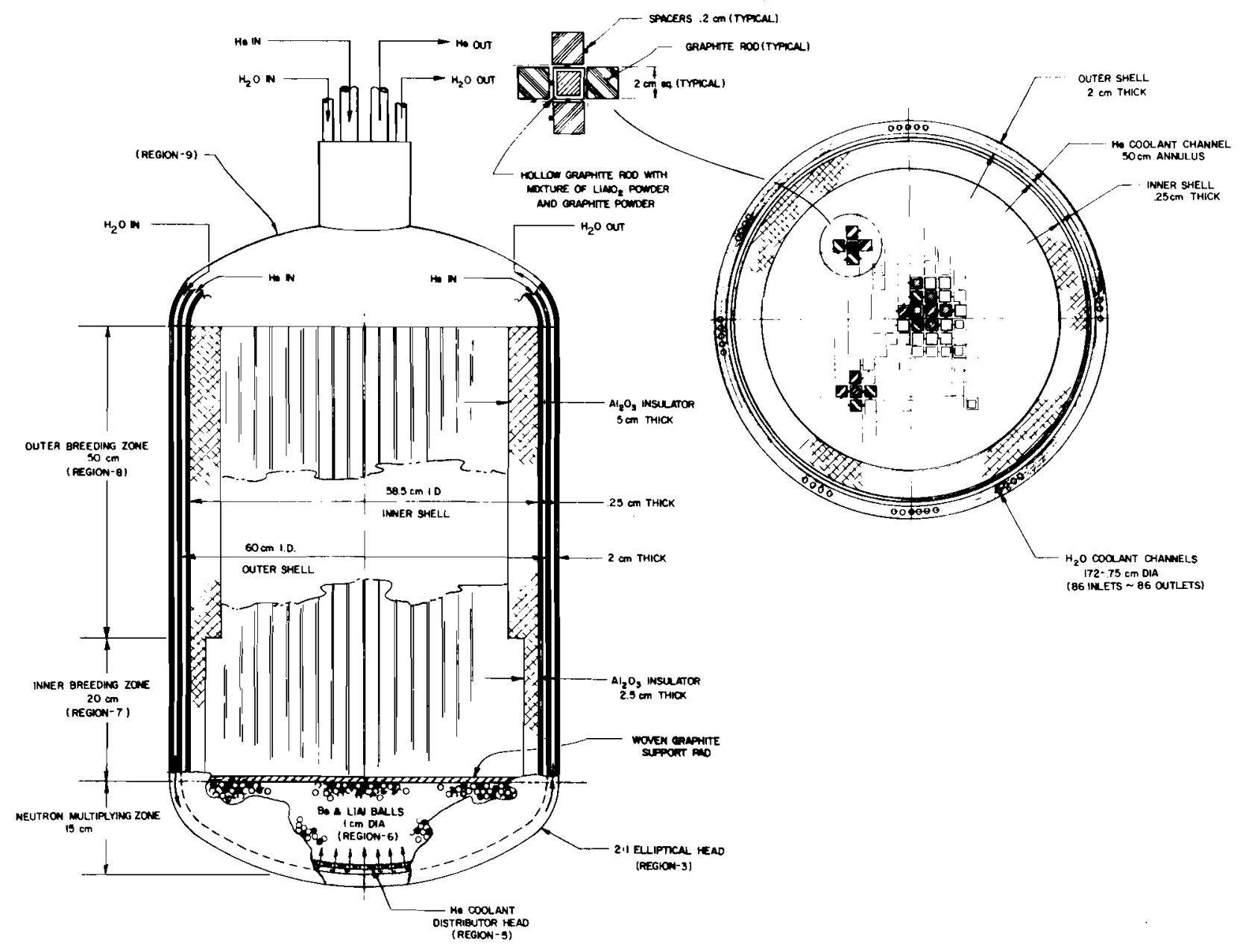

FIGURE 23 Typical Module in BNL Blanket

Radiation damage to the aluminum structure requires module replacement after 3 years in the reactor. This results in average rates of solid waste production of 230 metric tons per year of aluminum, 170 metric tons per year of graphite, and smaller amounts of other blanket constituents. Recycle is planned for additional amounts of graphite, most of the beryllium and much of the other module constituents except for aluminum.

Twelve independent helium/steam coolant loops remove high temperature heat from the blanket. Two thirds of the heat deposited in the blanket is removed by helium at $760^{\circ} \mathrm{C}$ and used to raise steam at $510^{\circ} \mathrm{C}$ and $177 \mathrm{~kg} / \mathrm{cm}^{2}$. The remainder of the blanket heat is removed by the pressurized water coolant at $204^{\circ} \mathrm{C}$, flashed to steam in a flash drum, and superheated by helium to $260^{\circ} \mathrm{C}$.

Electricity is generated by two turbine-generator units. A tandem compound unit is driven by the high temperature steam, and a single double-flow low pressure turbine is driven by the low temperature steam. The gross thermal efficiency of the combination is $34 \%$, and net plant efficiency is $32 \%$. 
As in UWMAK-I, spent fuel escaping from the plasma is collected by the divertor at the rate of $7.7 \mathrm{~kg} /$ day of tritium, $5.1 \mathrm{~kg} /$ day of deuterium and $0.9 \mathrm{~kg} /$ day of helium. The energy of collected ions is deposited on the surfaces of helium-cooled tubes which line the collection chambers of the divertor. Neutralized ions are then collected by cryogenic vacuum pumps which maintain the plasma chamber vacuum.

About $0.8 \mathrm{~kg} /$ day of tritium is bred in the solid lithium compound fertile material at the breeding ratio of 1.2. This diffuses into the helium coolant and is recovered from a cold-leg side stream by passing it through a bed of titanium particles which absorb it.

The total plant inventory of tritium is $10.1 \mathrm{~kg}$, of which $10.0 \mathrm{~kg}$ is in storage. Of the active inventory, $100 \mathrm{~g}$ are in the divertor cryopumps, $14 \mathrm{~g}$ are in the blanket fertile material, and an additional $15 \mathrm{~g}$ are in the recovery beds, associated cryopumps, and the helium coolant.

Blanket for the BNL Design - The aluminum alloy 6061 (Al-2\% Mg-2\% Si) is specified as structural material because it is expected to exhibit little long-lived radioactivity resulting from neutron activation. Minimization of residual blanket radioactivity is a primary goal of this design.

Tritium breeding is accomplished in solid materials containing lithium, specifically LiAl and $\mathrm{LiAlO}_{2}$. This is necessary because the aluminum structure lacks adequate resistance to corrosion by liquid lithium. The blanket inventory of tritium is reduced by minimizing the amc. $1^{t}$, of fertile material included in the blanket. Graphite is included for neutron moderation, and lithium enriched to $90 \%{ }^{6} \mathrm{Li}$ is specified. Consequently beryllium is required for neutron multiplication to make up for lost ${ }^{7} \mathrm{Li}$ tritium production reactions and to offset parasitic neutron captures in blanket materials.

Thermal insulation is required between low temperature regions required for integrity of the aluminum structural material and high temperature regions required for adequate thermal power plant efficiency. Low density ceramic alumina $\left(\mathrm{Al}_{2} \mathrm{O}_{3}\right)$ is specified for this function. Cooling for the structure is provided by water piped through passages within it, and helium is the coolant for the remainder of the blanket.

The blanket is located inside the toroidal field coils adjacent to the plasma (Figure 24). Gaps are provided in the blanket for plasma collection by the divertor. The blanket is $91 \mathrm{~cm}$ thick and it is followed by a $110 \mathrm{~cm}$ thick shield which protects the superconducting magnets from particles, radiation and heat penetrating the blanket. The entire cell in which the reactor is located is evacuated, which provides thermal insulation between the blanket and shield structure and the superconducting magnets.

The blanket is composed of 7200 individual cylindrical canisters which are oriented with their domed ends facing the plasma. These modules project into and are supported by, slabs of shielding material (Figure 25). In this description the $10 \mathrm{~cm}$ overlap region is considered to be part of the blanket. An individual blanket module is shown in Figure 23.

The domed ends of the modules form the blanket first wall. They are stressed in tension by the pressure forces of the helium coolant circulated through the module interior. The aluminum 


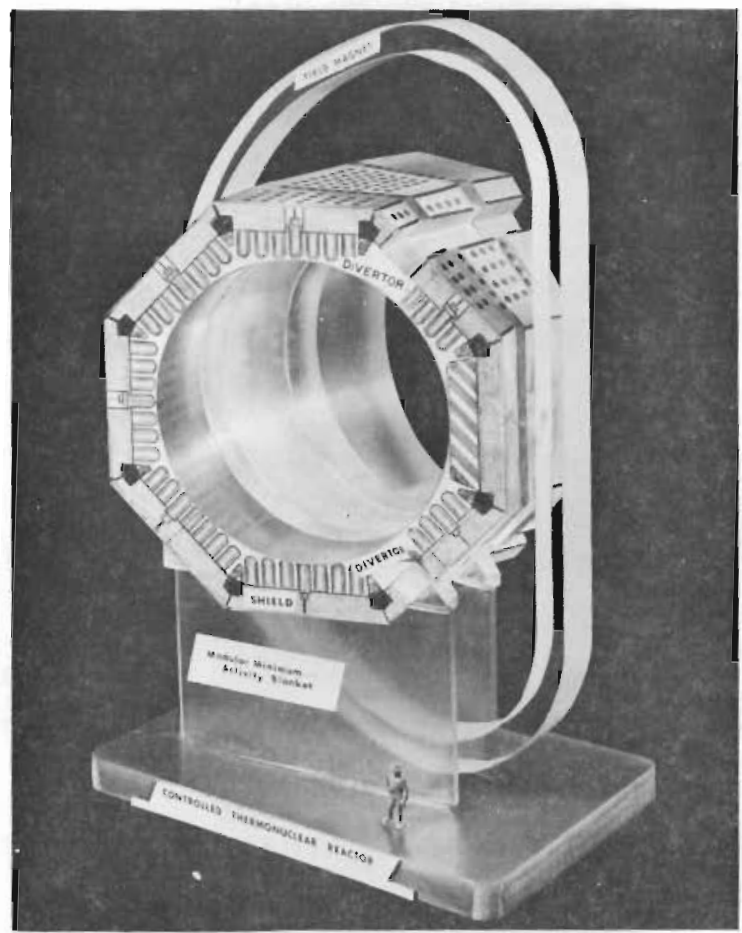

FIGURE 24 BNL BTanket Location

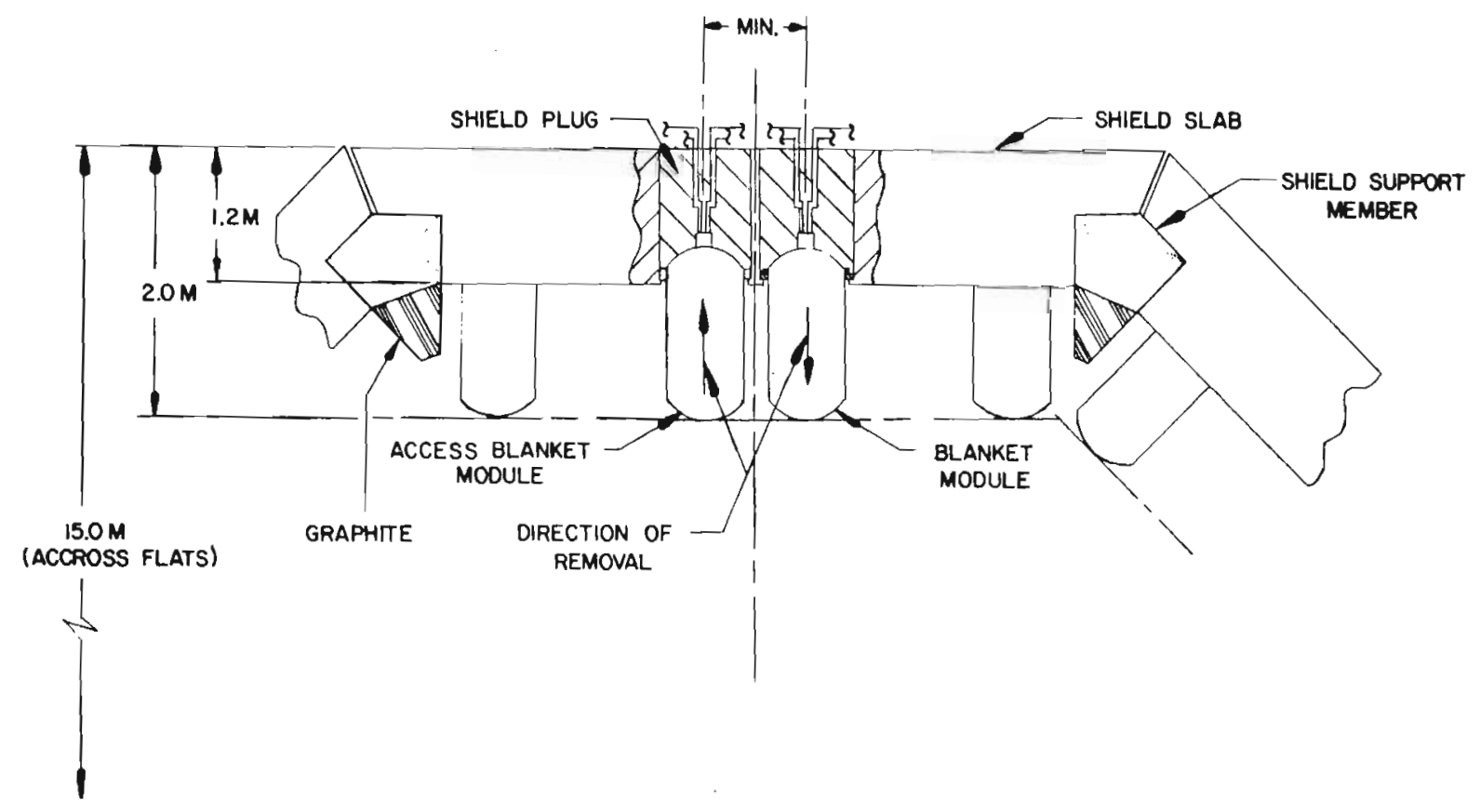

FIGURE 25 Typical Arrangement of BNL Blanket Modules in Shield Slabs 
shel1s of the modules are formed by bonding two layers together, leaving interior channels for cooling water to travel down one side of the module, across the domed end, and then back up the other side. This method of cooling allows the temperature of the aluminum structure to be maintained below $204^{\circ} \mathrm{C}$ despite much higher temperatures in the module interior.

The cylindrical module walls have a third layer of aluminum structure, to channel the inlet helium coolant $\left(177^{\circ} \mathrm{C}\right)$ to the bottom of the module. This structural material is protected from high temperatures in the module interior by an annular cylinder of $\mathrm{Al}_{2} \mathrm{O}_{3}$ ceramic insulator.

The helium coolant enters the module interior through a perforated distributor plate which covers the domed end of the module. The coolant flows through the module interior in intimate contact with the materials contained therein. Consequently, tritium bred in the fertile material diffuses into, and is carried away by, the helium coolant.

As the helium coolant travels through the module it first passes through a neutron multiplying region of $8 \mathrm{~cm}$ average thickness. This region is filled with $1 \mathrm{~cm}$ diameter balls of beryllium and of LiAl. The porous LiAI balls are pressed from small particles to enhance tritium diffusion to the coolant. The coolant then passes into a $70 \mathrm{~cm}$ thick neutron moderating region containing graphite rods and small $\mathrm{LiAlO}_{2}$ pellets. As in the neutron multiplying region the pellets are pressed from powder for porosity. "Inner" and "outer" portions are indicated for this region-when the modules are replaced after 3 years in the reactor most of the module contents are recycled except for materials in the inner moderating region. Figure 26 presents a schematic representation of the blanket as a whole, averaging over details of the individual modules which make up the blanket.

Blanket modules are not located in the central region of the torus (the region of small major radius). This is because access space between the magnet coils and the shield, which is

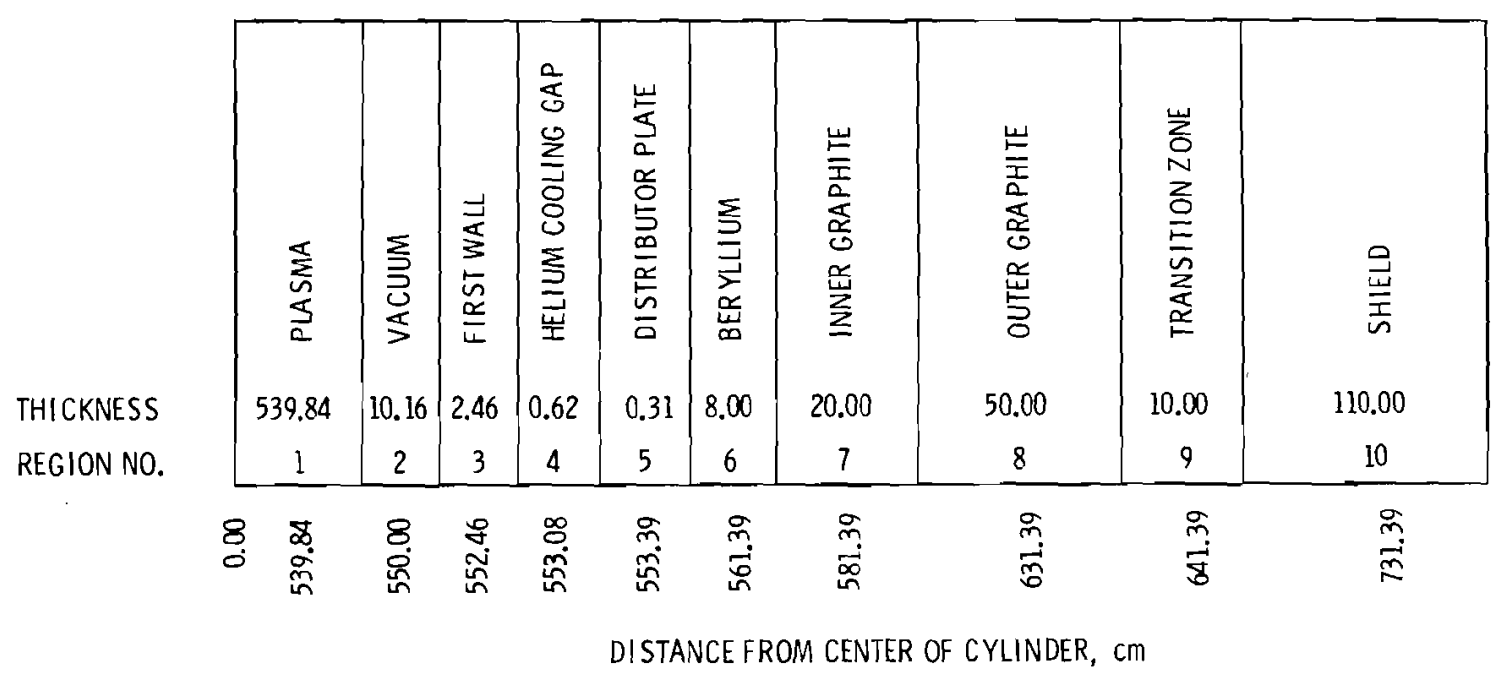

FIGURE 26 Simplified BNL Blanket Geometry Used in Anisn Calculations 
necessary for module removal and servicing, is severely restricted. In this region the blanket consists of $100 \mathrm{~cm}$ of graphite in the form of slabs, which are attached to the shield. This region comprises only $5 \%$ of the total blanket area.

The front $67 \mathrm{~cm}$ of graphite facing the plasma becomes very hot, and is cooled only by thermal radiation to other blanket surfaces. The expected surface temperature is $1800^{\circ} \mathrm{C}$ (below the evaporation temperature of $2000^{\circ} \mathrm{C}$ ), and the maximum internal temperature expected is $2200^{\circ} \mathrm{C}$. Coolant tubes are located in the $33 \mathrm{~cm}$ of graphite near the shield. Tritium breeding will be accomplished in this region in $\mathrm{LiAlO}_{2}$ pellets. These might be inserted into holes in the graphite, outgassing bred tritium to the vacuum system. Or they might be placed inside the coolant tubes, emitting bred tritium into the helium coolant stream.

The graphite region is designed to last the 30 year 1 ife of the plant. Radiation damage effects are expected to anneal out in the high temperature region, and neutron fluxes are expected to be low enough in the cooled region to permit lifetime operation.

The shield which supports the blanket modules is composed of aluminum structure (10\% by volume) and boron carbide (75\% $\mathrm{B}_{4} \mathrm{C}$ by volume) for neutron capture. Removable plugs are provided in the shield for removal of some blanket modules and access to others (Figure 25).

The reactor will be constructed from twenty-four $15^{\circ}$ sectors. Shield slabs will be supported by bulkheads located at the joints between sectors. Bulkhead location is indicated in Figure 27 , which also includes information on material requirements. The blanket for each sector will require 38 metric tons of aluminum, 8 metric tons of beryllium, 63 metric tons of graphite, 37 metric tons of $\mathrm{Al}_{2} \mathrm{O}_{3}$ and 0.2 metric tons of ${ }^{6} \mathrm{Li}$. The shield for each sector will require 45 metric tons of $\mathrm{Al}$ and 309 metric tons of $\mathrm{B}_{4} \mathrm{C}$.

Radiation damage to the aluminum structure limits the lifetime of the blanket modules. At the first wall loading of $1.25 \mathrm{MW} / \mathrm{m}^{2}$, it is expected that $1 / 3$ of the modules must be replaced each year. This will yield about 230 metric tons/yr of 6061 aluminum alloy $(\mathrm{Al}+2 \% \mathrm{Mg}+2 \% \mathrm{Si})$, requiring about $280 \mathrm{~m}^{3}$ of space. Additional waste produced will be 170 metric tons/yr of graphite, 43 metric tons/yr of $\mathrm{Al}_{2} \mathrm{O}_{3}$, 4 metric tons/yr of $\mathrm{LiAlO}_{2}$ and 1 metric ton/yr of beryllium, requiring a storage volume of $125 \mathrm{~m}^{3}$. Recycle is planned for another 260 metric tons/yr of graphite, 210 metric tons/yr of $\mathrm{Al}_{2} \mathrm{O}_{3}$, 41 metric tons/yr of beryllium, 4 metric tons/yr of LiAl0 and 3 metric tons/yr of LiAl on the assumption that economics will favor recycle over replacement.

At reactor shutdown the activity of the removed materials will be about $7 \times 10^{8} \mathrm{Ci}$, but this will decay to about $7000 \mathrm{Ci}$ after about 2 weeks. This remaining activity will be due primarily to the activation of impurities in the structural material, namely ${ }^{54} \mathrm{Mn},{ }^{119} \mathrm{Sn},{ }^{55} \mathrm{Fe}$ and ${ }^{65} \mathrm{Zn}$. Afterheat is not expected to be a problem, and compaction and onsite storage are planned. Ten years after removal the activity will have dropped to about $300 \mathrm{ci}$, due only to the long 1 ived isotopes ${ }^{26} \mathrm{Al}$ and ${ }^{14} \mathrm{C}$.

Heat Transfer System for the BNL Designs - Helium gas, which is circulated through the blanket, functions as the primary coolant. It absorbs $2 / 3$ of the heat deposited in the blanket. Water, 

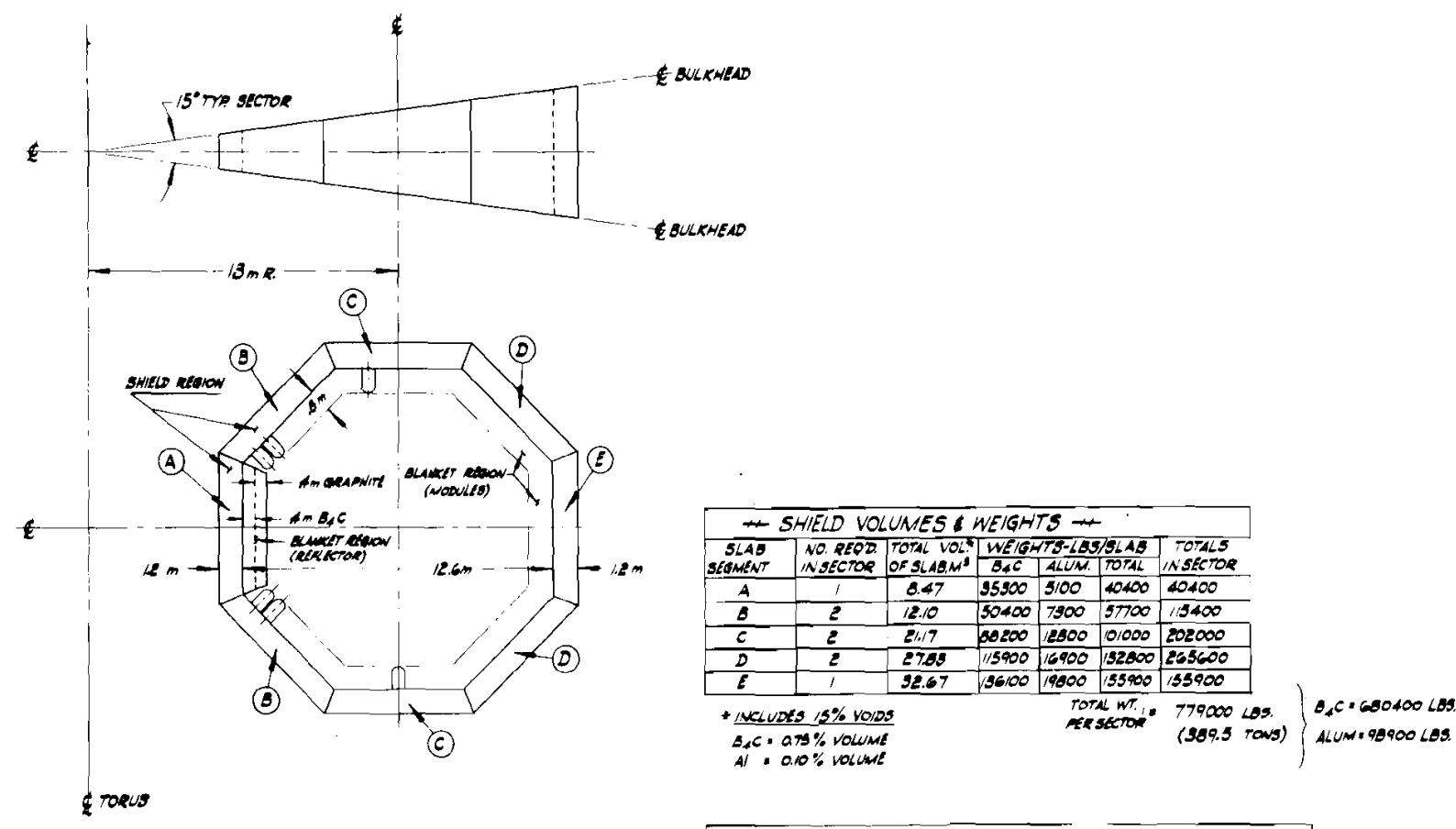

TYPICAL SECTION THRU TRUS
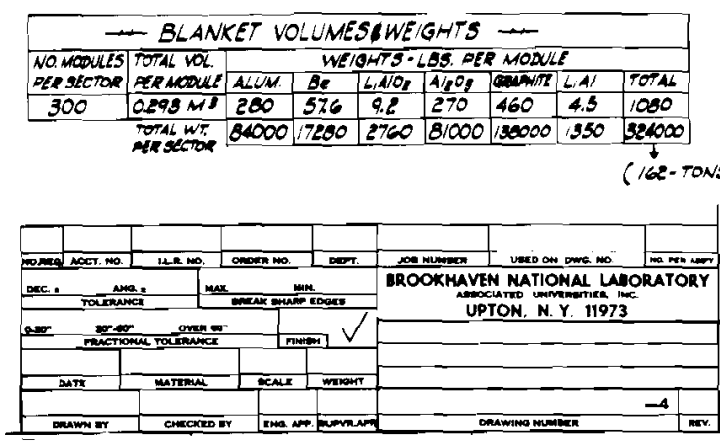

FIGURE 27 Bulkhead Location and Requirements of BliL Concept

however, is circulated through the first wall and also performs a primary cooling function. It absorbs the reamining $1 / 3$ of the blanket heat. Thus the design has two primary coolants.

Both the helium and the water carry the heat that they absorb out of the blanket. Most of the helium is used to raise high pressure steam to drive turbine generators; the remainder is used to superheat steam flashed from the water coolant. The steam from the water coolant is used in a direct cycle to drive turbine generators. This use of a coolant which passes through the reactor blanket to drive turbine-generators is unique to this design concept. Figure 28 is a schematic illustration of the helium and water coolant loops.

The helium/steam power cycle is adapted from an operating high temperature gas reactor [Summit (HTGR) Power Station $]^{(5)}$ and employs identical steam conditions. Twelve separate helium loops are employed, one for each two blanket sectors associated with one toroidal magnet coil. This 


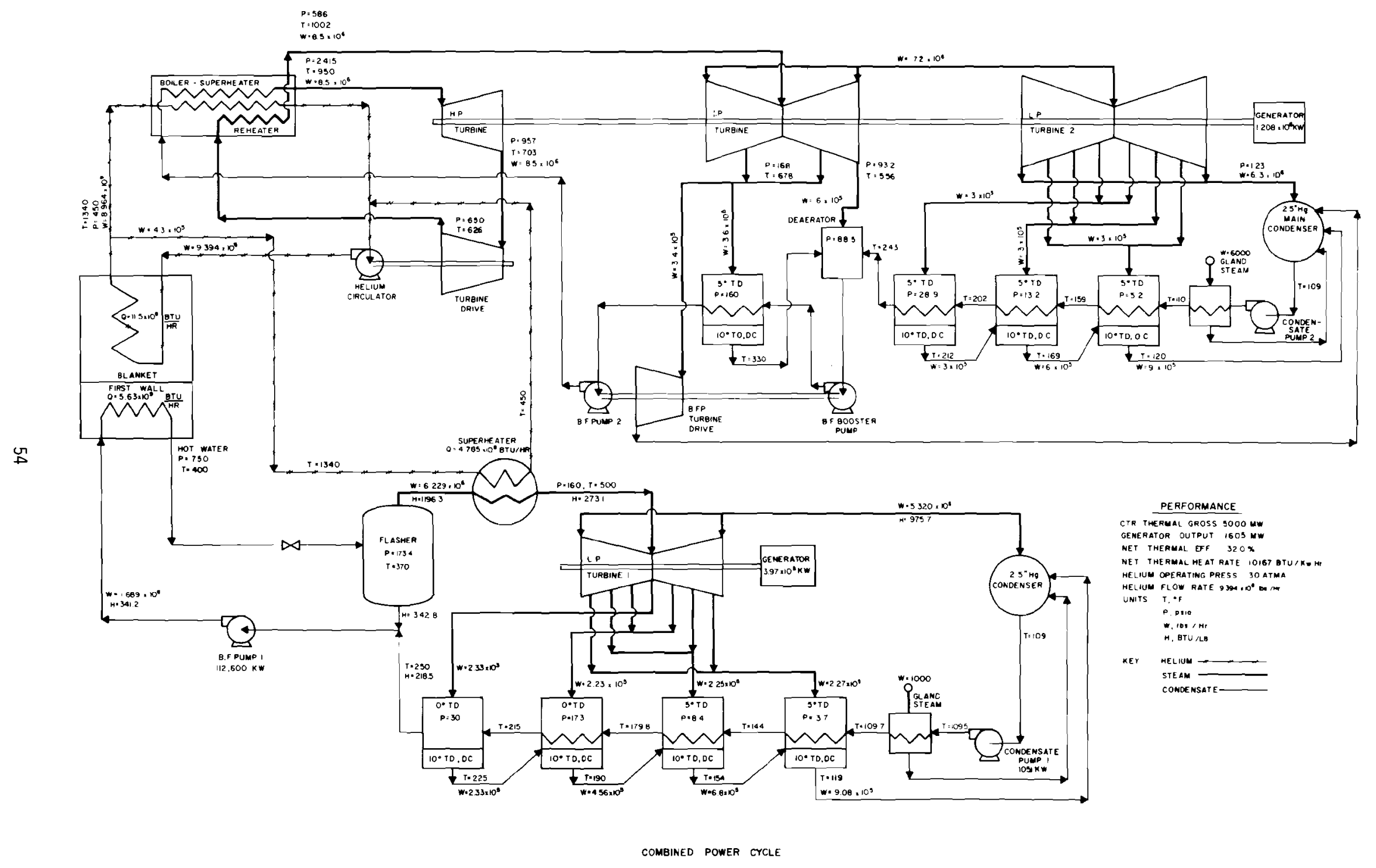

FIGURE 28 Helium and Water Coolant Loops in the BNL Concept 
reduces the tritium content of the helium coolant which might be available for leakage in the event of a break in one of the primary coolant loops.

The design requires $9.1 \times 10^{3} \mathrm{~kg}$ of helium coolant, which is circulated with a total mass flow rate of $4.1 \times 10^{6} \mathrm{~kg} / \mathrm{hr}$. The helium coolant enters the blanket at a temperature of $177^{\circ} \mathrm{C}$ and a pressure of $21 \mathrm{~kg} / \mathrm{cm}^{2}$. It exits at $760^{\circ} \mathrm{C}$, having experienced a pressure drop of only $0.003 \mathrm{~kg} / \mathrm{cm}^{2}$. Temperature and pressure profiles for the helium coolant in a typical blanket module are shown in Figure 29.

Most of the high temperature helium leaving the blanket is sent through steam generators and returned to the blanket by circulators. The steam generators are shown in Figure 28; they include superheat, and have one stage of reheat. The steam generators produce $3.9 \times 10^{6} \mathrm{~kg} / \mathrm{hr}$ of steam at $510^{\circ} \mathrm{C}$ and $177 \mathrm{~kg} / \mathrm{cm}^{2}$. Steam returned to the reheaters exits at $538^{\circ} \mathrm{C}$ and $41.3 \mathrm{~kg} / \mathrm{cm}^{2}$. About $5 \%$ of the helium leaving the steam generators is diverted through beds for the absorption of tritium. The processed helium is then returned to the main coolant stream through circulators. The water which is used to cool the aluminum walls of the blanket modules is flashed to steam, superheated by a portion of the high temperature helium coolant, and used to drive

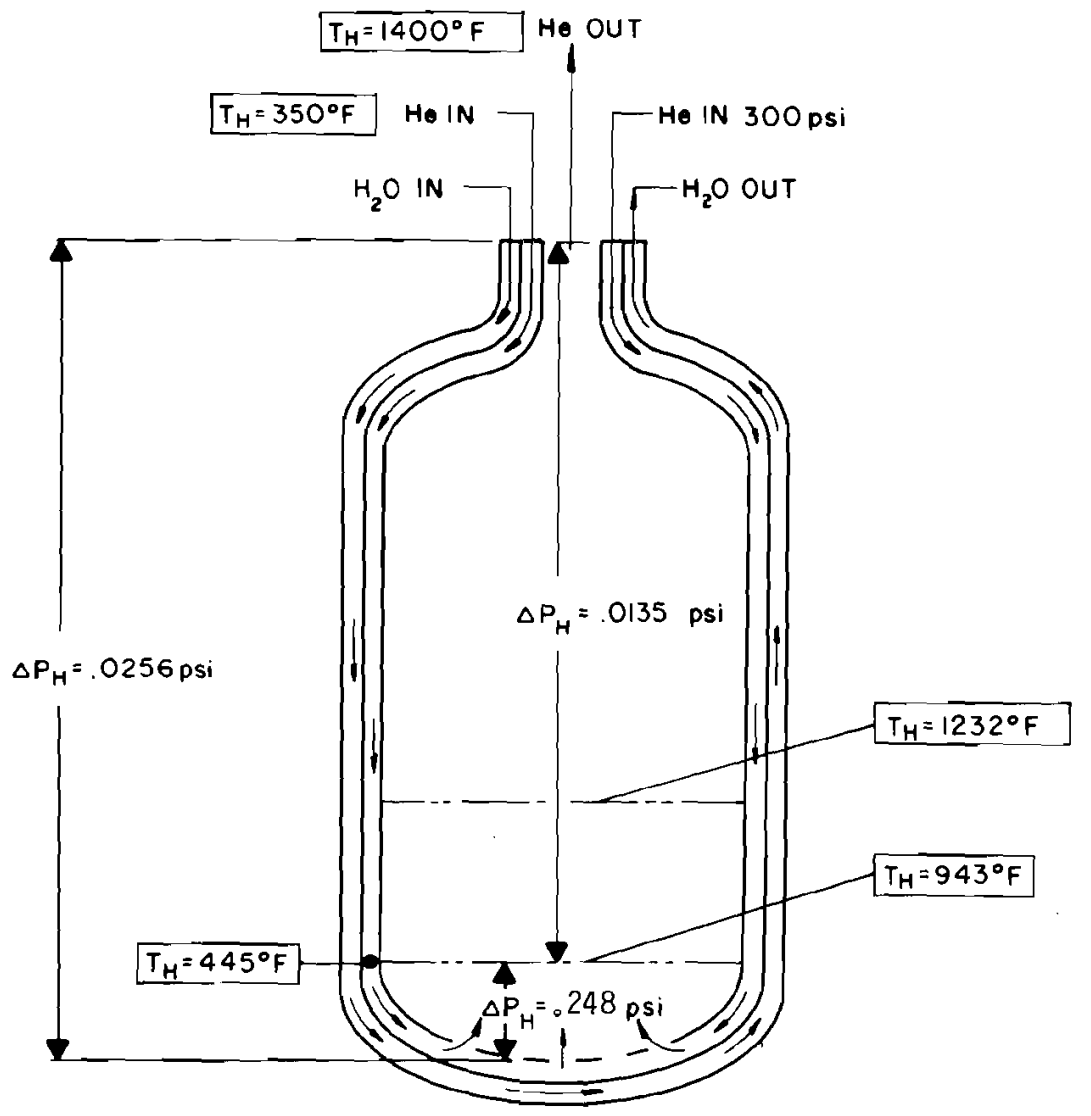

FIGURE 29 Typical Blanket Module Temperatures and Pressures for Helium Circuit in the BNL Concept 
turbine-generators. This water/steam direct cycle uses process conditions roughly equivalent to those of an operating pressurized water reactor [the Commanche Peak (PWR) Station]. (5) The amount of water primary coolant has not been determined; its flow rate is $7.7 \times 10^{7} \mathrm{~kg} / \mathrm{hr}$. The water enters the blanket at $188^{\circ} \mathrm{C}$ and leaves at $204^{\circ} \mathrm{C}$. The water pressure is $52.8 \mathrm{~kg} / \mathrm{cm}^{2}$, a considerable overpressure, to prevent boiling in the coolant passages. Temperature and pressure profiles for the water coolant in a typical blanket module are shown in Figure 30.

The water is flashed to steam in a flash drum, producing $2.8 \times 10^{6} \mathrm{~kg} / \mathrm{hr}$ of saturated steam at $12 \mathrm{~kg} / \mathrm{cm}^{2}$ pressure. This is superheated to $260^{\circ} \mathrm{C}$ by about $5 \%$ of the primary helium flow $\left(1.7 \times 10^{5} \mathrm{~kg} / \mathrm{hr}\right)$ and is used to drive low pressure turbine generators.

Electricity Generation System for the BNL Design - The flow schematic for the steam cycle is included in Figure 28. As is shown, a tandem-compound turbine arrangement is used to drive the main generator.

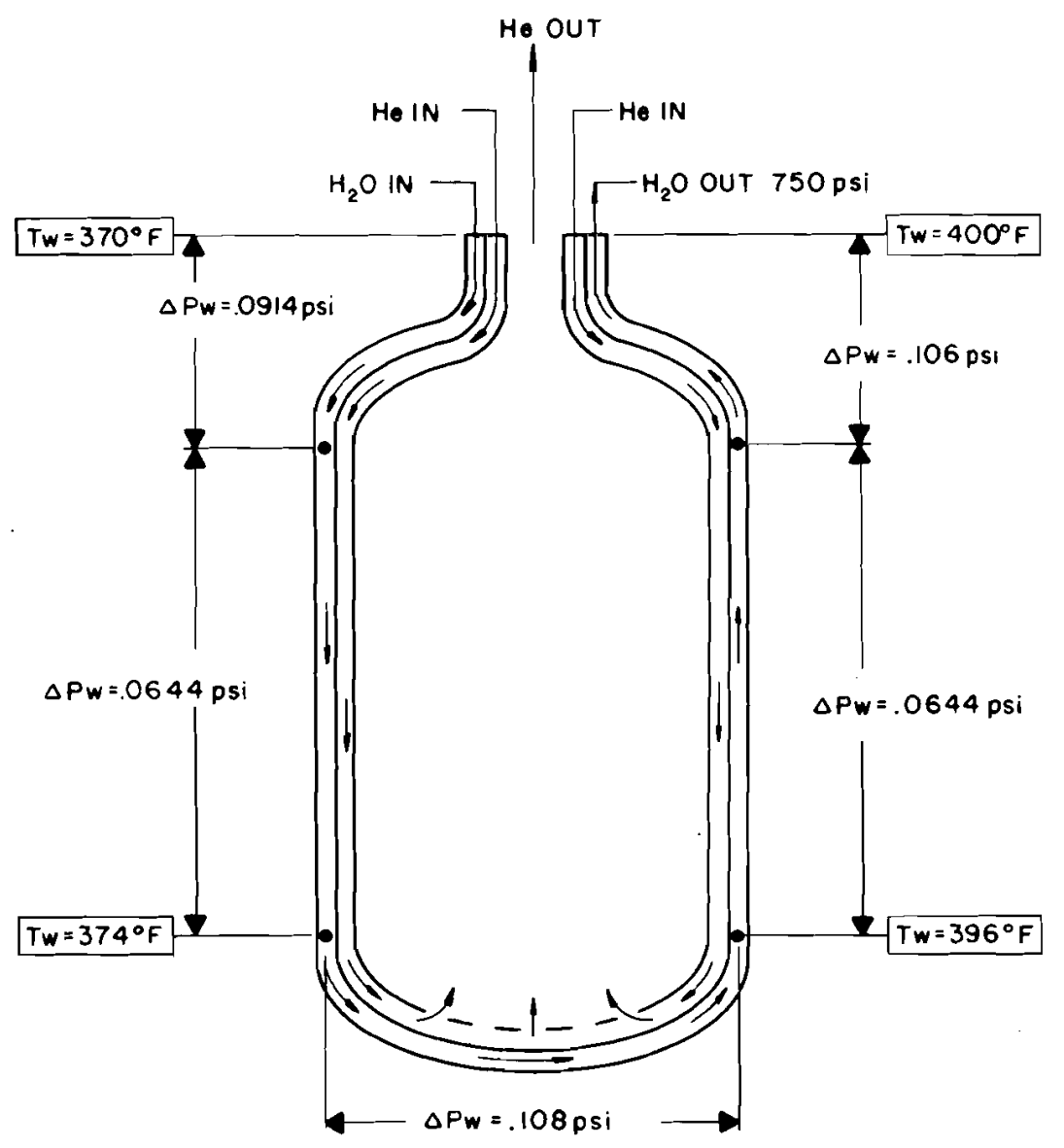

FIGURE 30 Typical Blanket Module Temperatures and Pressures for water Circuit in the BNL Concept 
Superheated steam flows from the steam generator superheater at a rate of $3.9 \times 10^{6} \mathrm{~kg} / \mathrm{hr}$. It drives a high pressure (HP) turbine, and is then routed through the reheater portion of the steam generator. After being reheated the steam flows through a double flow intermediate pressure (IP) turbine and a double flow low pressure (LP) turbine. Flow parameters are shown on Figure 28.

Steam is extracted variously from the IP and LP turbines, for heating feedwater for the steam generator, and to spin the turbines which drive the boiler feed pumps (BFP) which pump the feedwater into the steam generator. Most of the steam $\left(2.9 \times 10^{6} \mathrm{~kg} / \mathrm{hr}\right)$ passes through the turbines and is condensed at a pressure of $1.2 \mathrm{psia}$ and a temperature of $43^{\circ} \mathrm{C}$, for return to the steam generators as feedwater.

Superheated steam spins one double-flow low pressure turbine which drives the secondary generator. Extraction steam from the turbine is used to heat feedwater. (The boiler feed pump is electrically driven.) Steam enters the condenser at a rate of $2.4 \times 10^{6} \mathrm{~kg} / \mathrm{hr}$ and is condensed at a pressure of $1.2 \mathrm{psia}$ and a temperature of $43^{\circ} \mathrm{C}$.

Gross electrical outputs of the main and secondary generators are 1208 and 511 MWe. of the 1719 MWe total gross output, 114 MWe is used to operate boiler feed pumps in the secondary steam system. The net electrical generation is 1605 MWe.

Based upon a thermal power output of 5,000 MWt (which is interrupted for 6.5 minutes every 96.5 minutes) the gross thermal efficiency of generation is $34 \%$, the net plant efficiency is $32 \%$, and the net heat rate is $10,670 \mathrm{Btu} / \mathrm{kWh}$. Dry cooling towers are used to dissipate the waste heat to the atmosphere.

Spent Plasma Collection System for the BNL Design - As in the UWMAK-I design the partially burned fuel, containing deuterium, tritium, helium and impurity ions and atoms, is exhausted through the divertor. Collection rates are $7.7 \mathrm{~kg} /$ day of tritium, $5.1 \mathrm{~kg} /$ day of deuterium and $0.9 \mathrm{~kg} /$ day of helium.

Slots are provided in the upper and lower portions of the blanket to provide passages to collection chambers (Figures 21 and 24). The chambers themselves are not described.

Divertor surfaces are assumed to be composed of coolant-carrying tubes (e.g., SAP - Sintered Aluminum Product, composed of pure aluminum strengthened by very fine $\mathrm{Al}_{2} \mathrm{O}_{3}$ particles dispersed in the aluminum matrix). The tubes will be coated with a substance having a high diffusivity for hydrogen, e.g., palladium. Energetic ions from the plasma will strike and penetrate into the tube walls, depositing their kinetic energy for removal by the coolant. They will then rapidly diffuse out of the tubes as neutral gas atoms, for removal by vacuum pumps.

Neutralized plasma ions diffusing from tube surfaces are to be collected by high capacity cryopumps located behind the divertor surfaces. These cryopumps are expected to absorb all incident atoms and molecules, yielding a very high pumping speed for the divertor region. Numbers, sizes and capacities of the pumps are not stated. 
Virtually all of the ion energy is expected to be deposited as heat on the divertor surfaces. Disposition of that heat by the coolant is not described. It is expected that only about $10^{-4} \%$ of the reactor thermal output $(5 \mathrm{~kW})$ is received by the cryopumps as thermal load. Divertor surfaces will need to be replaced periodically in a manner similar to the replacement of blanket modules.

Bred Tritium Recovery System for the BNL Design - The breeding ratio of tritium in the 1 ithium blanket is 1.2 . The $0.8 \mathrm{~kg} /$ day of tritium which is bred diffuses from the blanket constituents directly into the helium primary coolant. It is recovered by titanium getter beds which process a portion of the helium exiting from the steam generator.

The getter beds receive $5 \%$ of the primary coolant flow, at a temperature of $500^{\circ} \mathrm{C}$. The getter beds through which the helium is passed contain $10 \%$ titanium particles $0.02 \mathrm{~cm}$ in diameter, and $90 \%$ inert material, typically $\mathrm{Al}_{2} \mathrm{O}_{3}$. A typical bed design is shown in Figure 31 . There will be about 30 such beds, two for each of the 12 coolant loops and six spares.

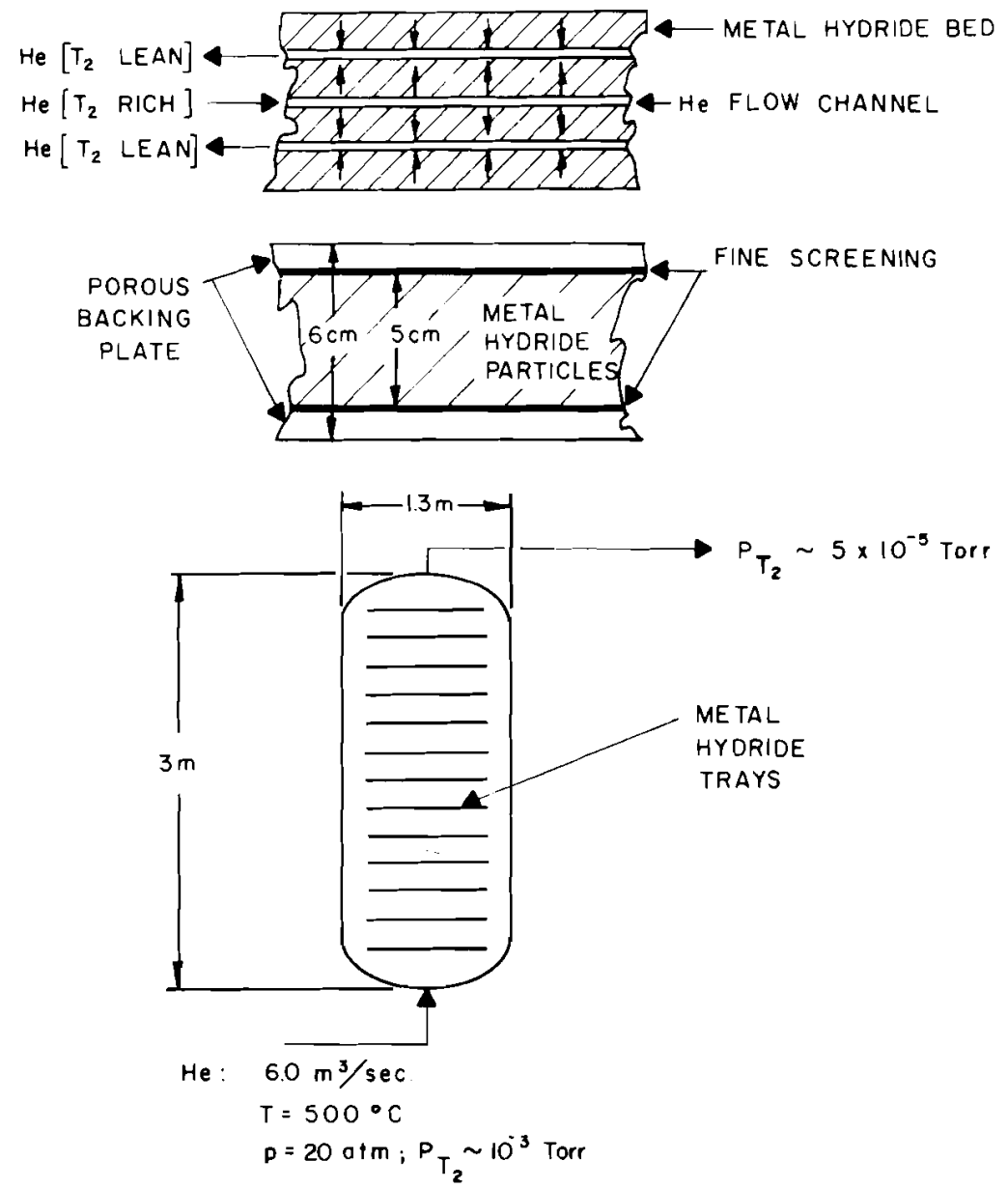

FIGURE 31 Typical Getter Bed in BNL Concept 
The beds receive helium for 15 minutes, and then tritium is desorbed for 15 minutes. Desorption occurs at the same temperature as absorption. It is accomplished by vacuum pumping the beds. The desorbed tritium is absorbed in the cryogenic vacuum pumps then released and pumped to the fuel system.

The tritium inventory of the blanket is primarily determined by the rate of diffusion from the solid particles in which it is bred. The tritium inventory in the helium coolant depends primar$i l y$ on the fraction of the coolant (5\%) passed through the getter beds. The tritium inventory in the getter beds depends strongly on the change in concentration between absorption and desorption phases, which should be small. These inventories are listed below.

The total tritium inventory (Table 9) of the plant is estimated to be $101 \mathrm{~kg}$, of which $10.0 \mathrm{~kg}$ is in storage. Tritium flows in the plant are indicated in Figure 32.

TABLE 9 BNL Concept Tritium Inventory $(a)$

$\begin{array}{lc} & \text { Tritium Grams } \\ \text { Blanket fertile material } & 14 \\ \text { Helium primary coolant } & 1 \\ \text { Primary coolant recovery beds } & 7 \\ \text { Recovery bed cryopumps } & 7 \\ \begin{array}{l}\text { Divertor cryopumps } \\ \quad \text { Plant active inventory }\end{array} & 100 \\ \quad \text { Storage } & \underline{10,000} \\ \text { Total plant tritium inventory } & 10,129 \\ & \\ \text { a. The tritium stored is 14.5 times the daily consumption } \\ \text { rate, and 1.2 times the daily injection rate. }\end{array}$

Containment Building for the BNL Design - The reactor is located in a steel lined vacuum tank (Figure 21). This tank must be designed to withstand the pressure which would be generated by simultaneous failure of both helium and pressurized water primary coolant systems. The vacuum tank is $52 \mathrm{~m}$ in diameter and $32 \mathrm{~m}$ high at the shoulder. Additional structure above the tank supports a containment dome which is at ground level.

Water and helium primary coolants are piped from the vacuum tank through ducts (Figure 21). Helium circulators and steam generators are located in a primary containment building which is not described. Tritium leakage into the atmosphere from this building, is recovered by an undefined process.

\subsubsection{University of Wisconsin Tokamak UWMAK-II}

Power plant and reactor parameters are given in Table 2. Preparation of an illustrated description of this concept is awaiting issuance of the complete draft design description by the University of Wisconsin. 


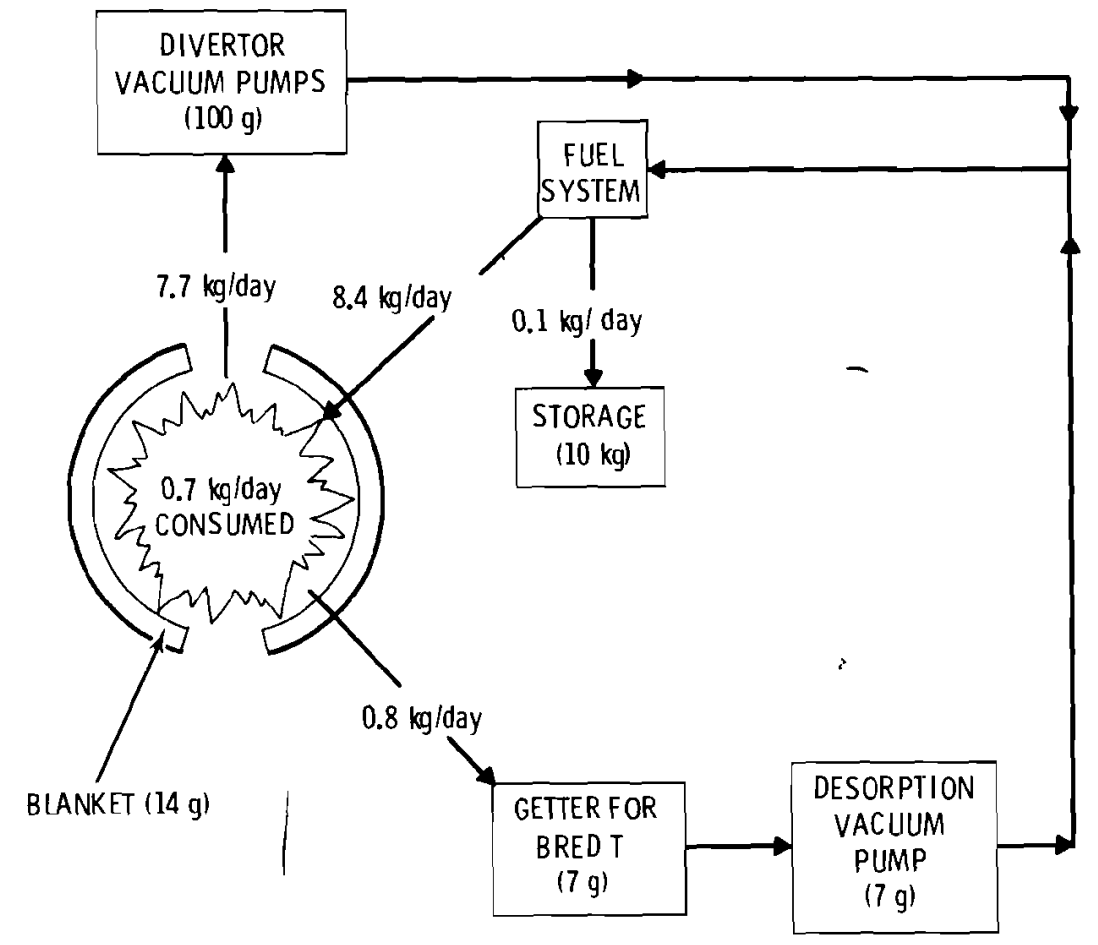

FIGURE 32 Tritium Flow and Inventory Schematic for the BNL Concept

\subsubsection{Princeton Tokamak (PPPL)}

Summary Description - The PPPL Tokamak power plant ${ }^{(6)}$ produces 2030 MWe of net electrical power on a continuous basis from a thermal energy release of $5305 \mathrm{MWt}$. The thermonuclear cycle of the Tokamak is 100 minutes long, of which shutdown and refueling require 3 minutes. Continuous electrical generation is possible because of the large heat capacity of reactor blanket materials - despite continuous coolant flow the blanket temperature decreases less than $50^{\circ} \mathrm{C}$ during the shutdown period. The overall power plant layout is shown in Figure 33.

The reactor blanket is composed primarily of the molten salt (fluorine, lithium, beryllium) flibe which is cooled by circulating helium. The helium is used to raise steam at $538^{\circ} \mathrm{C}$ and $260 \mathrm{~kg} / \mathrm{cm}^{2}$ to drive the turbine-generators. Major power plant systems are identified and their functional relations are indicated in Figure 34.

The reactor is located inside of the containment building shown in Figure 33. All pipes carrying high temperature tritium-containing fluids are double walled, with a helium purge between the walls to minimize tritium leakage into the containment building atmosphere. The diameter of the reactor is $35 \mathrm{~m}$. The major and minor radii of its toroidal plasma chamber are $11 \mathrm{~m}$ and $3.6 \mathrm{~m}$, respectively. It is constructed primarily of PE-16 structural material. PE-16 (43\% $\mathrm{Ni}, 39 \% \mathrm{Fe}$, $18 \%(\mathrm{C})$ is expected to be less susceptible to radiation induced swelling than stainless steel.

Plasma confinement is achieved by superconducting magnets designed for dynamically stable operation. Niobium-tin superconductor, cooled by supercritical helium vapor, is to be used in all 


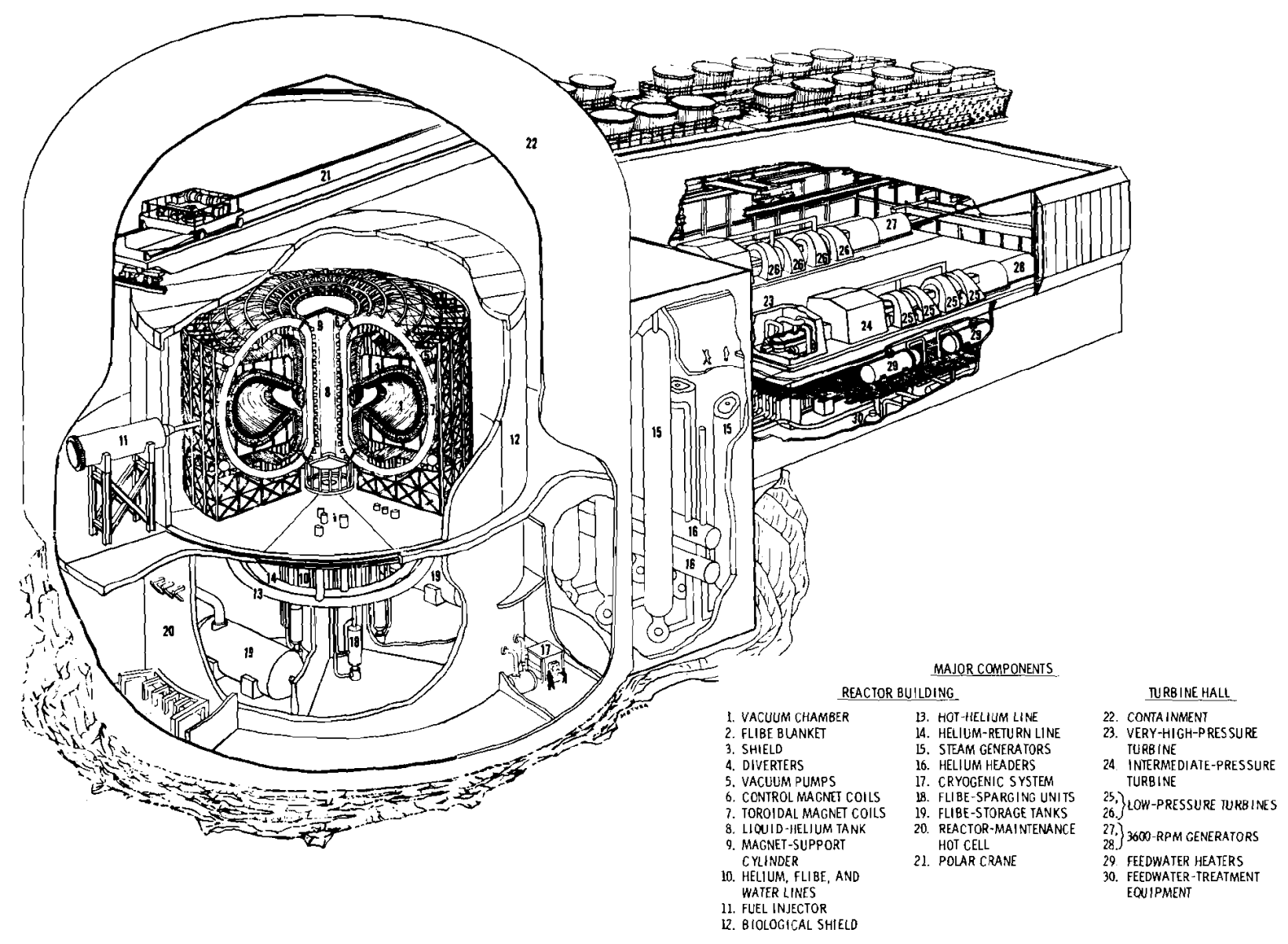

FIGURE 33 Layout of the PPPL Tokamak Power Plant

the magnets - in the toroidal plasma confinement coils, in the vertical field coils, in the poloidal divertor coils and in the control windings. The toroidal magnetic field is produced by 48 coils having a bore diameter of $12.1 \mathrm{~m}$. Maximum and plasma-center magnetic fields are 16.0 and $6.0 \mathrm{~T}$. Additional magnetic fields are produced by the plasma current and by the poloidal divertor and vertical field coils.

During reactor startup the fuel gas is preionized by a breakdown oscillator, and the plasma current is established by air-core transformer action of the divertor, control and vertical field coils. A further function of the divertor coils is to guide escaping plasma particles to collection chambers. This protects the plasma chamber wall from erosion and from sputtered impurities.

The plasma is heated ohmically by the plasma current of $14.6 \mathrm{MA}$. However, to achieve ignition of the thermonuclear burn, additional heating by neutral atom beams carrying $8 \mathrm{MW}$ of power is required for 10 seconds. The injectors, which will supply an equivalent beam current of 1600 amperes of $5 \mathrm{keV}$ neutral atoms have not been designed. 


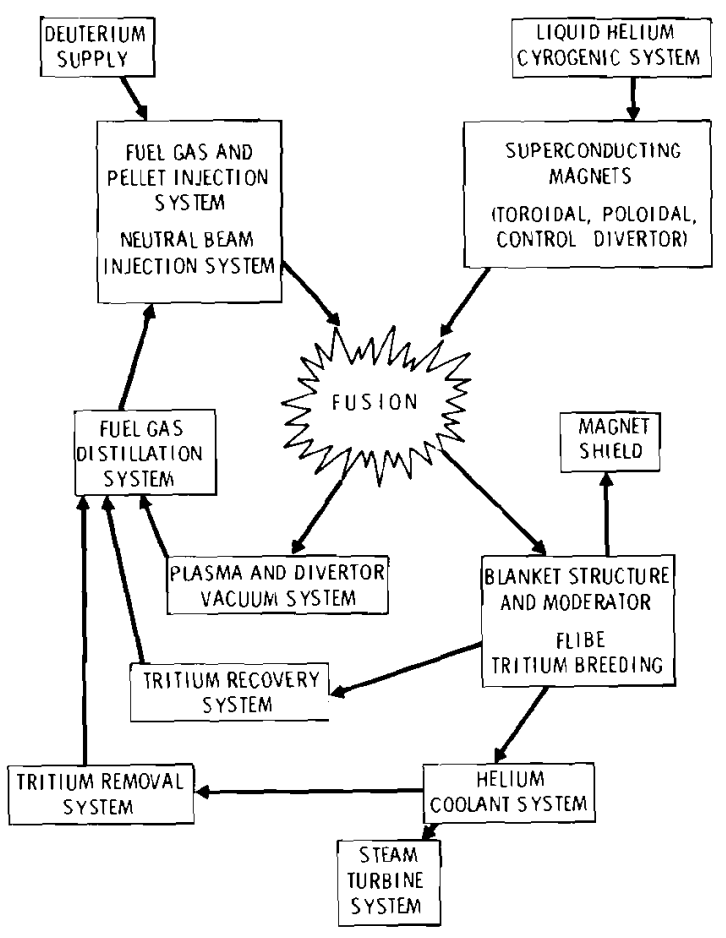

FIGURE 34 Functional Relations Between Systems of the PPPL Tokamak Power Plant

The plasma contains equal numbers of deuterium and tritium atoms, plus a $5 \%$ addition of argon impurity atoms. The plasma chamber fuel charge is $0.3 \mathrm{~g}$ of tritium and $0.2 \mathrm{~g}$ of deuterium. The ion temperature of the plasma is $30 \mathrm{keV}$.

Fuel is injected into the plasma in pellet form by an undefined injector. The fuel injection rate is $6.0 \mathrm{~kg} /$ day of tritium and $4.0 \mathrm{~kg} /$ day of deuterium. Only $9 \%$ of it is burned before escaping from the plasma, yielding a fuel consumption rate of $0.5 \mathrm{~kg} /$ day of tritium and 0.35 $\mathrm{kg} /$ day of deuterium. Unburned fuel is purified by cryogenic distillation and is recycled to the plasma.

Energy collection and tritium breeding take place in an $80 \mathrm{~cm}$ thick blanket located inside the magnet coils, adjacent to the plasma. Further attenuation of particles and radiation is provided by a shield 50 to $80 \mathrm{~cm}$ thick located between the blanket and the superconducting magnets (Figure 35).

The blanket is constructed of PE-16. It is basically a large toroidal tank of flibe moderator/ fertile material. The first wall is protected by a layer of thin coolant-carrying tubes and the wall itself contains channels for the helium coolant. Coolant-carrying serpentine tubes (Figure 35 ) remove heat from the flibe. The toroidal blanket is composed of 24 separate $15^{\circ}$ sectors. 


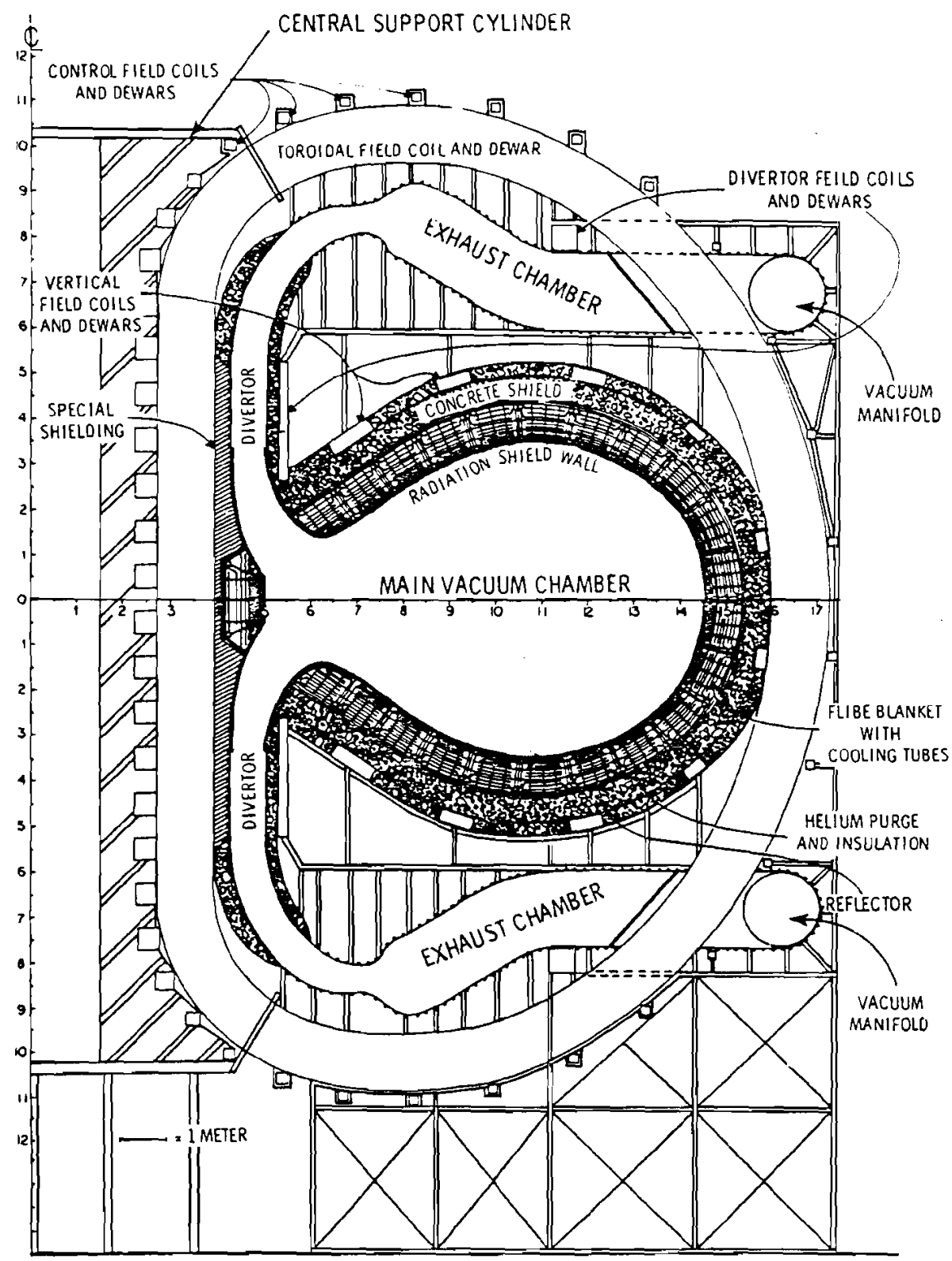

FIGURE 35 Section View of the PPPL Tokamak

Radiation induced embrittlement of the PE-16 structure requires replacement of blanket segments after 5 years in the reactor. This results in an average rate of solid waste production of 220 metric tons/yr. An additional 13 metric tons/yr of corrosion products is expected to be removed from the flibe.

Heat is removed from the blanket by a single helium/steam coolant loop. Blanket temperatures are 1 imited to $660^{\circ} \mathrm{C}$ by the temperature limitations of PE-16. Hot leg temperatures in the helium/steam system are $638^{\circ} \mathrm{C}$ and $538^{\circ} \mathrm{C}$, respectively. Helium circulators use HTGR technology. 
Electricity is generated by two generators driven by a cross-compound steam turbine arrangement. The thermal efficiency of the plant is $45 \%$; net plant efficiency is $38 \%$.

Spent fuel escaping from the plasma is collected by the divertor, at the rate of $5.5 \mathrm{~kg} /$ day of tritium, $3.6 \mathrm{~kg} /$ day of deuterium, and $0.7 \mathrm{~kg} /$ day of helium. Neutralization of the collected ions takes place at the entrance to the divertor exhaust chambers, and the resulting neutral gas atoms are removed by 96 vacuum pumps. Before and during neutralization the ions radiate their energy to coolant-carrying tubes that 1 ine the walls of the divertor channel and the exhaust chamber.

About $0.55 \mathrm{~kg} /$ day of tritium is bred in the flibe fertile material at the breeding ratio of 1.04 . This tritium, in the chemical form tritium fluoride, is recovered by circulating the flibe from the blanket, outgassing the TF from a flibe spray, and electrolyzing it to produce tritium and fluorine. The total plant inventory of tritium is $2.57 \mathrm{~kg}$, of which $2.02 \mathrm{~kg}$ is in storage. of the active inventory, $505 \mathrm{~g}$ is in the fuel system, $40 \mathrm{~g}$ is in the blanket flibe and structure, and $7 \mathrm{~g}$ is in the helium coolant.

Plasma Confinement System of the PPPL Design - The magnet coils are called toroidal field coils, vertical field coils, divertor coils and control windings. The latter are the transformer coils which maintain the 14.6 MA plasma current.

Al1 four sets of coils are superconducting and are constructed from thick $\mathrm{Nb}_{3} \mathrm{Sn}$ superconductors. $\mathrm{Nb}_{3} \mathrm{Sn}$ can be operated in higher magnetic fields than $\mathrm{NbTi}$ superconductor, it remains superconducting at higher temperatures than $\mathrm{NbTi}$ does, and the superconductor costs for the necessary

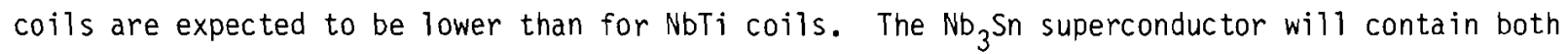
copper stabilizing material and stainless steel ribbon in addition to superconducting tape. The superconductor will carry $10 \mathrm{kA}$ per conductor, and operate at temperatures between 8 and $10^{\circ} \mathrm{K}$. Cooling will be supplied by supercritical helium vapor.

The superconducting coils are designed for dynamically stable operation. This is less conservative than cryogenically stable design in that the allowed current density is roughly double that for cryogenic stability. This design criterion is based upon economic reasons plus the belief that the design of dynamically stable magnets will be better understood in the next decade.

The toroidal field magnet assembly consists of 48 coils. They are evenly spaced around a supporting cylinder to form the desired toroidal shape (Figure 36). The coils are supported by a segmented cylinder $14 \mathrm{~m}$ high, made of work hardened stainless steel. The cylinder weighs 1100 metric tons, and is housed in a segmented dewar. The weight of the toroidal field coils is supported by low conductivity rods and pylons from the inside structure of the dewar.

One of the $48 \mathrm{D}$-shaped coils is shown in Figure 37. It has an inner width of $16 \mathrm{~m}$ and a tota 1 thickness of $1.2 \mathrm{~m}$. Each of the coils weighs 130 metric tons. The coil shape is chosen so that the superconductor from which it is wound is not subject to bending moments. Consequently no massive supporting disk is required, as the stainless steel ribbon included in the superconductor is designed to support tensile forces. The superconductor will carry a current of $10 \mathrm{kA}$, at a 


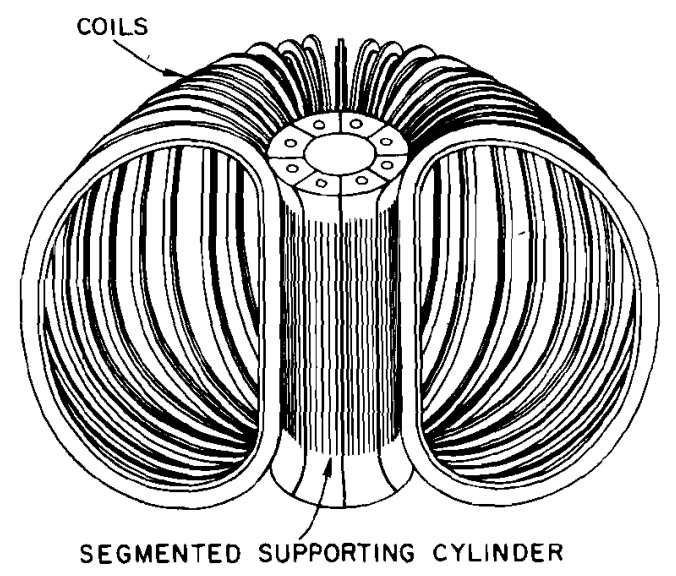

FIGIJRE 36 PPPL Toroidal Field Magnet Assembly

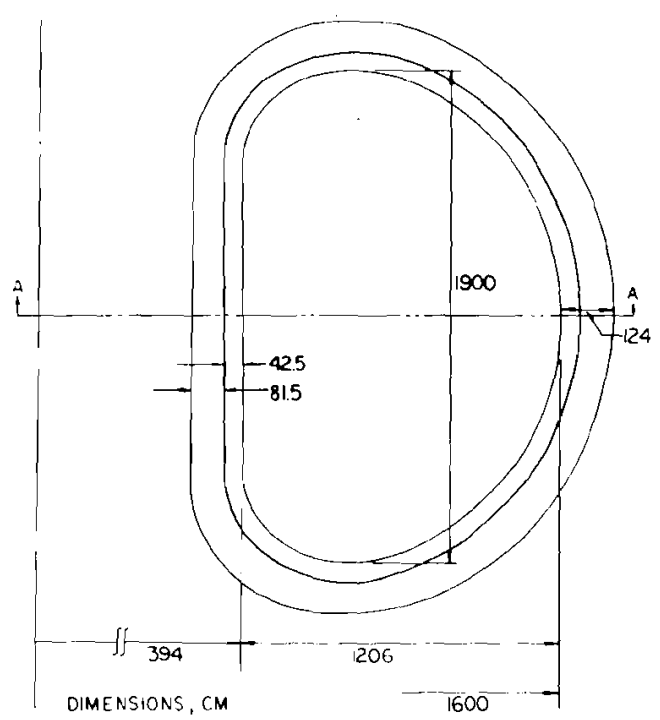

FIGURE 37 Dimensions and Configuration of the "D" Shaped Toroidal Field Coils in the PPPL Tokamak

current density of $2.2 \mathrm{kA} / \mathrm{cm}^{2}$. The coils are designed to produce a maximum field at the innermost conductor of $16 \mathrm{~T}$. The corresponding field at the plasma axis is $6 \mathrm{~T}$.

The vertical field coils, divertor field coils and control windings 1 ie in planes parallel to the plane of the torus. The vertical field coils and the divertor coils are located inside the toroidal field coils, and the control windings are located outside the D's (Figure 35). There are 10 vertical field coils, 4 divertor coils and 42 control field coils. The effective currents carried by the coils range up to $5.5 \mathrm{MA}$.

The vertical field coils, divertor coils and control windings are constructed from the same type of superconductor as the toroidal field coils $\left(\mathrm{Nb}_{3} \mathrm{Sn}\right)$ for system compatibility. However, because these coils are pulsed each burn cycle, the amounts of stainless steel and copper in the conductors are tailored to the pulsed operating conditions. 
The control coils are located so that they do not produce a net field at the plasma. Flux changes in these coils ma intain the plasma current against resistive losses during the 97 minute thermonuclear burn. During startup, however, the vertical field coils and the divertor coils are pulsed on simultaneously with the control windings. Flux changes due to all three sets of coils induce the plasma current, with the main energy supplied by the vertical field coils.

The vertical field determines the position of the plasma ring during the burn, and the divertor field combines with it and the fields of the plasma current and of the toroidal field coils to produce magnetic surfaces near the plasma which are shaped as shown in Figure 38. Plasma particles diffusing farther from the plasma axis than the separatrix are directed by the outer field lines into the divertor collection chambers (Figure 35 ).

The dewars for the toroidal field coils are typical of all the dewars. The toroidal field coil dewar is composed of an inner and outer vacuum-tight stainless steel wall. The vacuum space of $3 \mathrm{~cm}$ is filled with layers of superinsulation. A total of $280 \mathrm{~kW}$ of heat must be removed from the various coils by the cryogenic system. Of this, $150 \mathrm{~kW}$ are due to heat conduction, $35 \mathrm{~kW}$ are due to eddy current heating when the fields are pulsed, and $95 \mathrm{~kW}$ are due to neutron and radiation heating. The toroidal field contains 250 gigajoules of energy, which is most of the stored magnetic energy. In addition, a maximum of 8 gigajoules is stored in the fields of the divertor and control field coils, and of the plasma current during operation.

Plasma Heating System in the PPPL Tokamak - The plasma current of 14.6 MA, which is required for confinement, provides a major plasma heating function. Thermonuclear ignition (when fusion energy deposited in the plasma by alpha particles equals a 11 energy losses from the plasma) cannot be achieved through this ohmic heating alone. However, it is expected that ohmic heating at low plasma density $\left(4.6 \times 10^{11} \mathrm{~cm}^{-3}\right)$ will be sufficient to achieve a situation called "n-squared ignition."

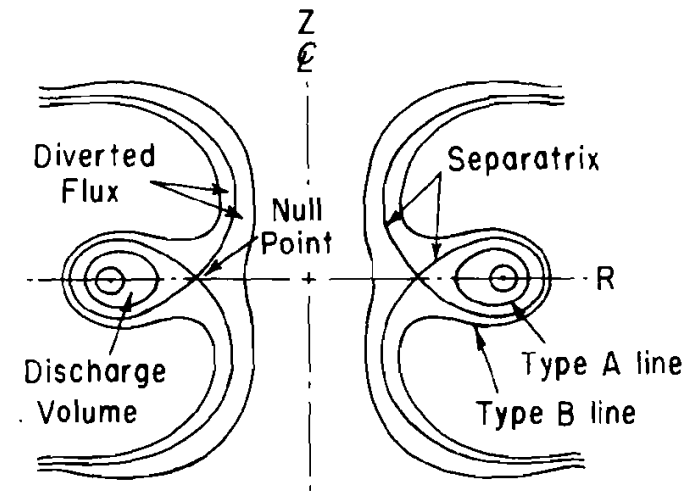

FIGURE 38 Magnetic Field Contours Near the Plasma in the PPPL Design 
"N-squared ignition" occurs about 13 seconds after reactor startup, as the plasma current reaches its full value of 14.6 MA and a plasma temperature of about $5 \mathrm{keV}$ is achieved. At " $n$-squared ignition" the plasma heating by fusion alpha particles equals those plasma energy losses which increase as the square of the density.

After "n-squared ignition" is achieved the plasma density and temperature are increased by the injection of beams of neutral fuel atoms. The injection energy of the neutral beams is $5 \mathrm{keV}$, and the time required to achieve true ignition is determined by the available injection current. Eight MW of neutral beam power are to be injected, corresponding to an equivalent beam of current of 1600 amperes. The injectors have not been designed.

It is expected that ignition conditions will be achieved after about 10 seconds of beam injection. At the plasma the operating point ion temperature will be $\langle 30 \mathrm{keV}\rangle$ and its fuel ion density will be $5 \times 10^{13} \mathrm{~cm}^{-3}$.

The reactor will be ignited about 14 times per day. The injector throughput per startup will be about $0.5 \mathrm{~g}$ of tritium and $0.3 \mathrm{~g}$ of deuterium.

Fuel System for the PPPL Design - Fuel must be supplied to the plasma at a rate of $6.0 \mathrm{~kg} / \mathrm{day}$ of tritium and $4.0 \mathrm{~kg} /$ day of deuterium. (The fuel also contains a $5 \%$ addition of argon atoms.) Only $9 \%$ of the fuel undergoes fusion reactions before it escapes from the plasma. The actual consumption of fuel in fusion reactions is $0.5 \mathrm{~kg} /$ day of tritium and $0.35 \mathrm{~kg} /$ day of deuterium. The fuel system functions to separate unburned fuel from recycled plasma, to purify both recycled fuel and bred tritium recovered from the blanket, to prepare the fuel in pellet form for injection, and to inject it into the plasma.

About $11 \mathrm{~kg} /$ day of recycled plasma and bred tritium is purified by cryogenic fractional distillation. The purification process is indicated in Figure 39. The effluent to be purified is first cooled to its dewpoint for input to the primary fractionating column. Any condensable impurities are trapped out in the precooler. In the fractionating column helium and protium $\left({ }^{1} H\right)$ are separated as vapor from the liquid, which contains the fuel in the forms of $D_{2}$, DT and $T_{2}$, plus argon. About $0.7 \mathrm{~kg} /$ day of hel ium and $7 \mathrm{gm} /$ day of $\mathrm{H}_{2}$ are removed.

The vapor of the primary fractionating column contains some HD and HT, in addition to $\mathrm{H}_{2}$ and helium, and consequently is subject to further processing. The hydrogen isotopes are condensed in a cyclic condenser, and the helium is disposed of by adding it to the helium primary coolant. The condensate is then reprocessed in a secondary fractionator to further purify the $\mathrm{H}_{2}$, after which it is oxidized to water, absorbed in a desiccant, and stored as waste.

The drag steam fractionator shown in the figure operates intermittently to process heavy impurities trapped in the precooler, and also to additionally process the primary fractionator bottoms for impurity removal.

The liquid fuel stream from the primary fractionator is stored prior to makeup of consumed deuterium and fabrication of pellets for injection into the plasma. (Makeup of consumed tritium occurs at the input to the purification process where bred tritium recovered from the blanket 


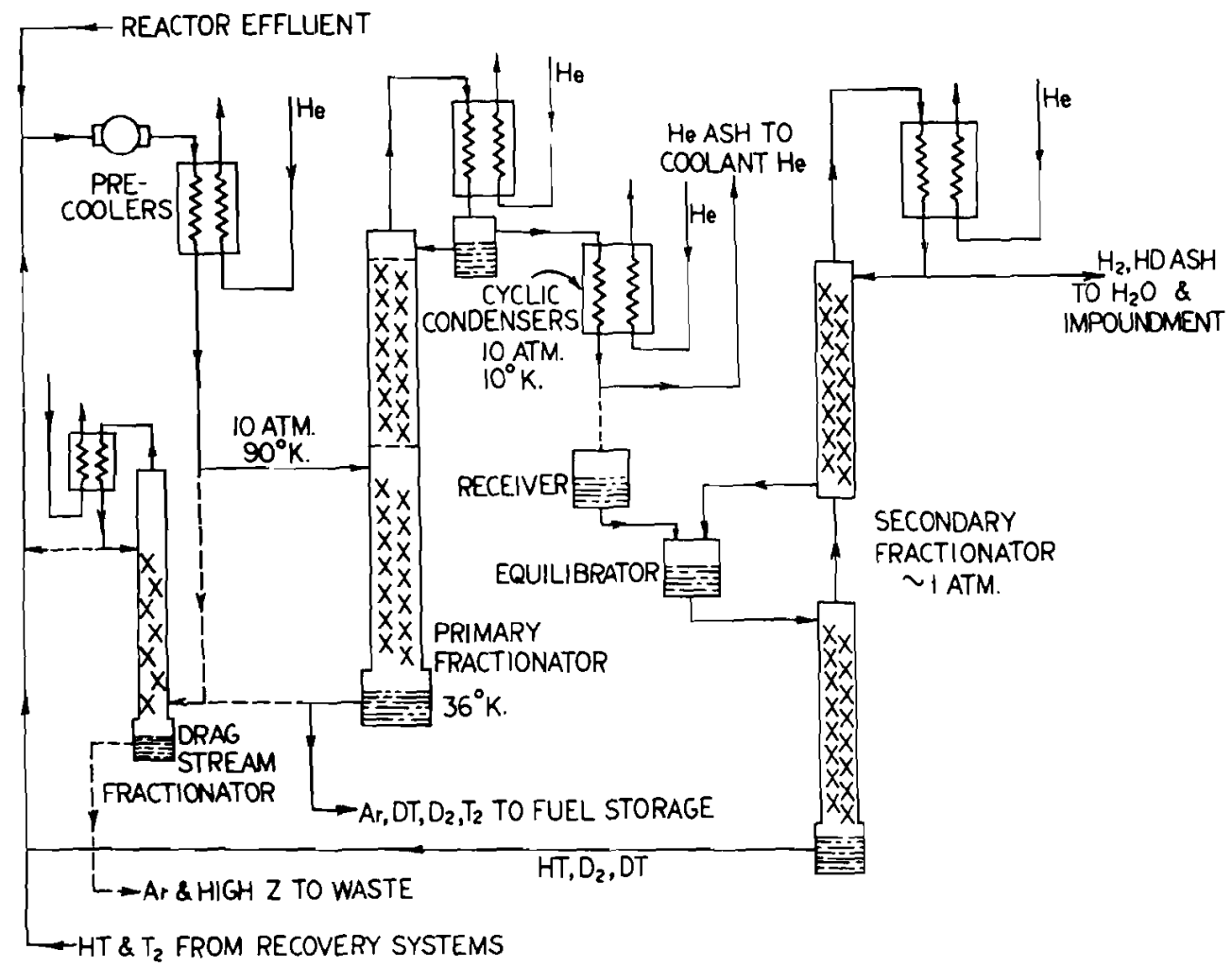

FIGURE 39 Fuel Purification Schematic for the PPPL Tokamak

is added to the recycled plasma.) Due to the insolubility of argon in the fuel at low temperatures, pelletizing and injection operations (undesigned) are expected to pose difficult technological challenges.

High velocity ballistic injection of fuel pellets deep into the plasma is specified in this design but the method is undefined. (Edge-deposited fueling is noted as an unexplored alternative.) Pellet injection is chosen over neutral beam injection because less power is required, and because fewer energetic plasma ions are expected to charge-exchange with neutral fuel atoms, escaping confinement as high energy neutrals to bombard the plasma chamber walls.

Fueling requirements could be met by the injection of $1 \mathrm{~mm}$ pellets at a rate of $300 / \mathrm{sec}$ and a velocity of $5 \times 10^{6} \mathrm{~cm} / \mathrm{sec}$. (Each such pellet would contain about $0.1 \%$ of the reactor fuel charge of $0.3 \mathrm{~g}$ of tritium and $0.2 \mathrm{~g}$ of deuterium.) The pellets could be formed by emission of a liquid jet into an evacuated chamber through a vibrating nozzle--nozzle vibrations causing droplet formation, and evaporative cooling causing freezing. The pellets could then be charged and electrostatically accelerated for injection. However, for pellets of this size an unreasonably high accelerating potential of $10^{8}$ volts is required.

Blanket of the PPPL Design - The blanket surrounding the toroidal plasma chamber is designed: to contain a large amount of lithium; to allow the easy extraction of heat energy and tritium; and to be self supporting under its gravity and vacuum loads. Steel alloy structural material 
is specified because industry capabilities for fabricating the refractory metals are inadequate. The nickel steel PE-16 (43\% $\mathrm{Ni}, 39 \% \mathrm{Fe}, 18 \% \mathrm{Cr}$ ) is specified because it may swell less under irradiation than stainless steel does. Lithium for tritium breeding is contained in the molten salt flibe (47\% LiF, $53 \% \mathrm{BeF}_{2}$ ) which fills most of the blanket. Flibe is specified instead of liquid lithium because it is less corrosive to steel alloys at elevated temperatures. The beryllium constituent of the flibe acts as a neutron multiplier, allowing adequate tritium breeding despite parasitic neutron captures in the fluorine. The blanket coolant is helium gas.

The blanket is located inside the toroidal field coils adjacent to the plasma (Figure 35). It is continuous except for gaps provided for plasma collection by the divertor. In the inner region of the torus, where the divertor channels pass quite close to the toroidal field coils, the blanket is replaced by a special shield of iron and lithium hydride to minimize neutron penetration and consequent damage to the superconducting magnets.

The blanket is $80 \mathrm{~cm}$ thick. It is followed by a polyethelene neutron reflector $5 \mathrm{~cm}$ thick and a shield of high-density concrete containing extra iron and boron-bearing minerals. The vertical field coils are embedded in the shield (Figure 35). The shield thickness is $50 \mathrm{~cm}$ at these coils and $80 \mathrm{~cm}$ in between them. Thermal insulation is provided between the blanket, shield and magnet coils by evacuated spaces which separate these regions.

The blanket is basically a large toroidal tank of flibe. However, because $16 \%$ of the power generated in the plasma is deposited on the first wall by electromagnetic radiation, the first wall of the tank is protected by a layer of thin PE-16 tubes carrying helium coolant. These tubes run parallel to the major circumference of the torus. They are welded together and are supported from the blanket wall by PE-15 strips running parallel to the tubes.

The vacuum wall of the blanket is a smooth plate honeycombed with rectangular channels for helium coolant. This box-like structure supports the slightly higher than atmospheric pressure of the flibe. The pressure forces on the wall are supported by tensile forces in support plates that connect the wall structure to outer blanket regions. The radiation shield, vacuum wall and support plates are shown in Figure 40.

The flibe in the blanket is cooled by heat exchange to helium-carrying tubes located within the blanket. The tubes lie in planes perpendicular to the axis of the plasma. They carry the coolant first along the inner wall, and then in a serpentine path from inner to outer blanket regions (Figure 41). Because power deposition is greatest near the inner wall and decreases with distance into the blanket, the serpentine spacing increases with distance from the inner wall.

The flibe is circulated past bundles of cooling tubes. This is shown in Figure 42 , which is Section B-B of Figure 41. Flibe circulation is necessary to remove it for tritium extraction, and also enhances the heat removal capabilities of the cooling tubes. The flibe follows a complex path as it is circulated through the blanket which is segmented by support plates and flow channels. This path is indicated in Figure 43. 


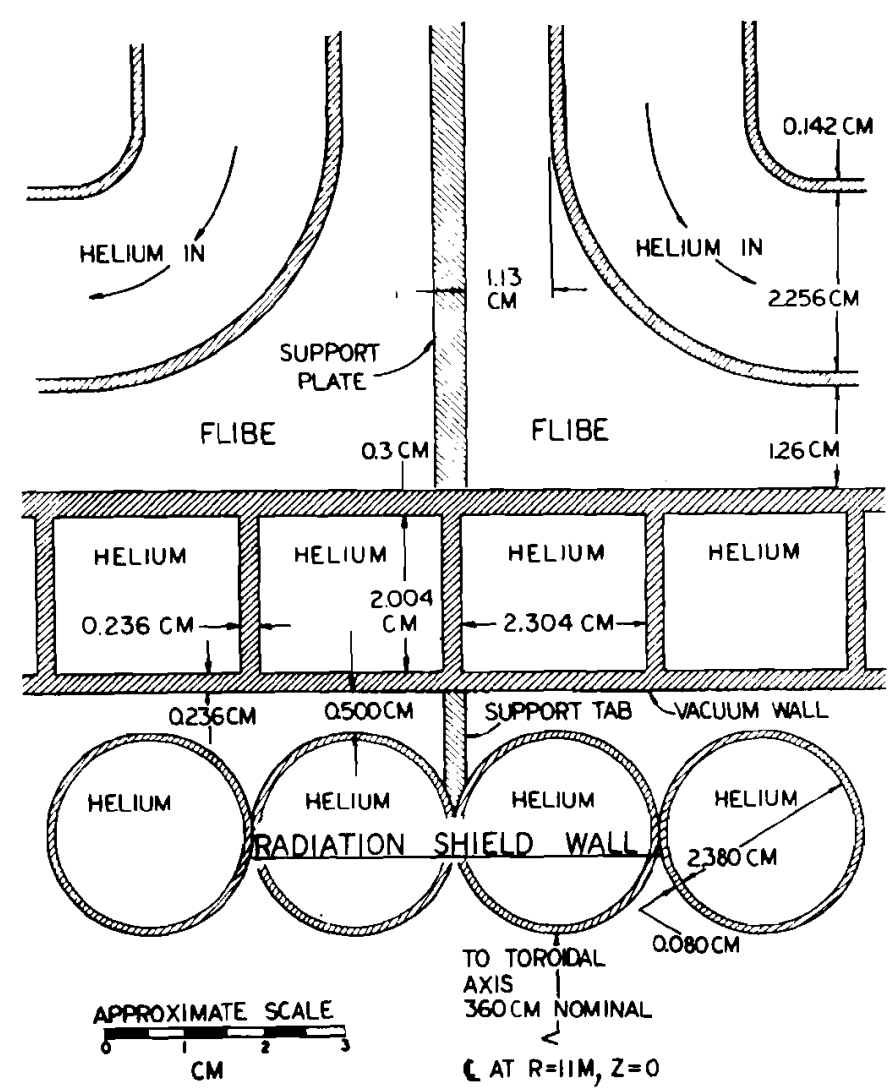

FIGURE 40 Detailed Cross Section of Radiation Shield Wa11, Vacuum Wall and Inner Part of the Flibe Blanket in the PPPL Design

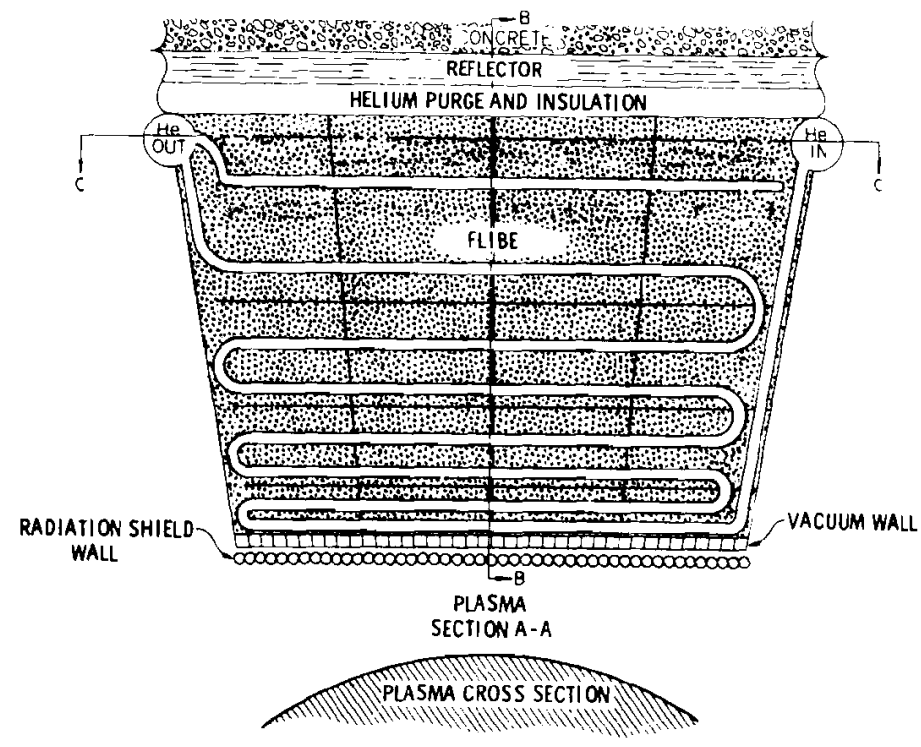

FIGURE 41 PPPL Nominal Blanket Section. (View is along axis of plasma.) 


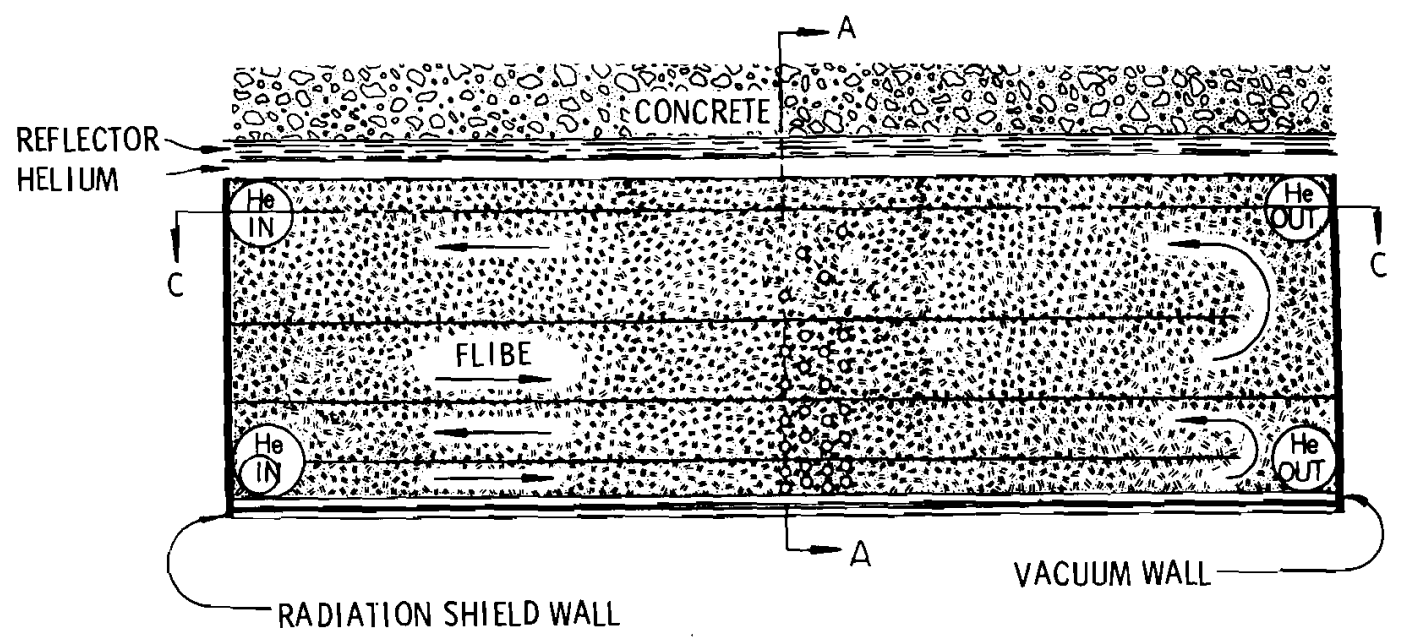

SECTION B-B

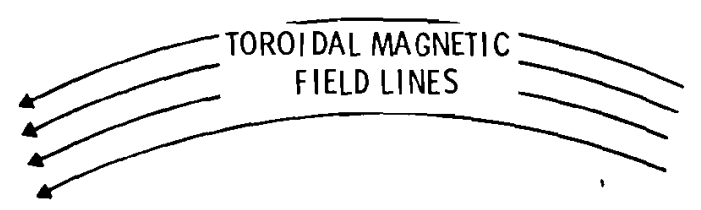

FIGURE 42 Nominal Blanket Section of the PPPL Tokamak.

(View is along minor circumference.)

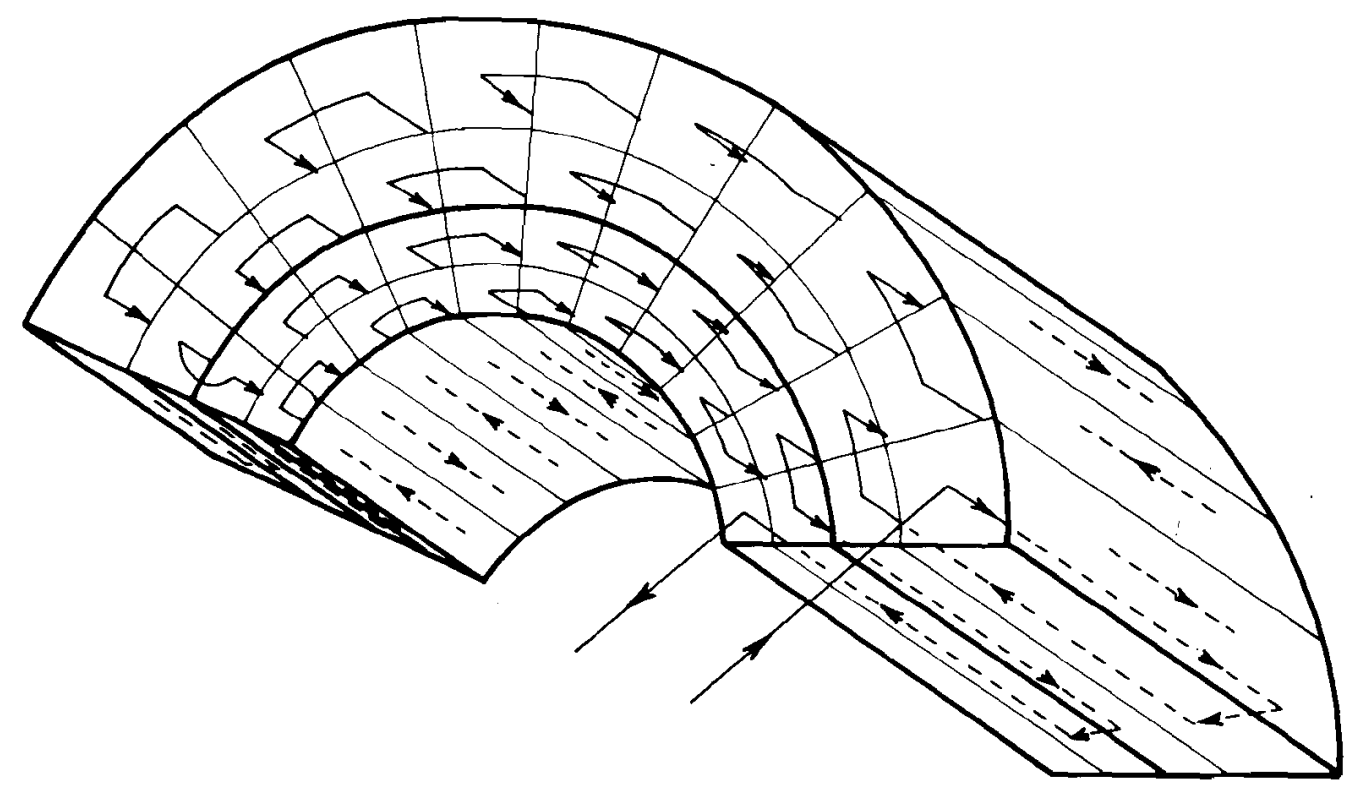

FIGURE 43 Flibe Flow Path Through One-Half Sector of the PPPL Design 
Figure 44 presents a schematic layout of the blanket, reflector and shield regions. Material volume fractions shown for the various regions are derived from the actual tube and structure layout. Compositions are indicated for the various materials included.

The special shield region in the central region of the reactor is designed for maximum neutron attenuation in minimum thickness. It is cooled by helium gas. The first $27 \mathrm{~cm}$ of this region consists of alternating plates of austenitic iron and LiH, 45 and 55 volume percents, respectively. This is followed by a $1 \mathrm{~cm}$ coolant flow channel. The final shield Tayer consists of $2 \mathrm{~cm}$ of lead $(\mathrm{Pb})$, as a gamma shield. Therma insulation $(5 \mathrm{~cm})$ is located between this shield and the superconducting toroidal field coils.

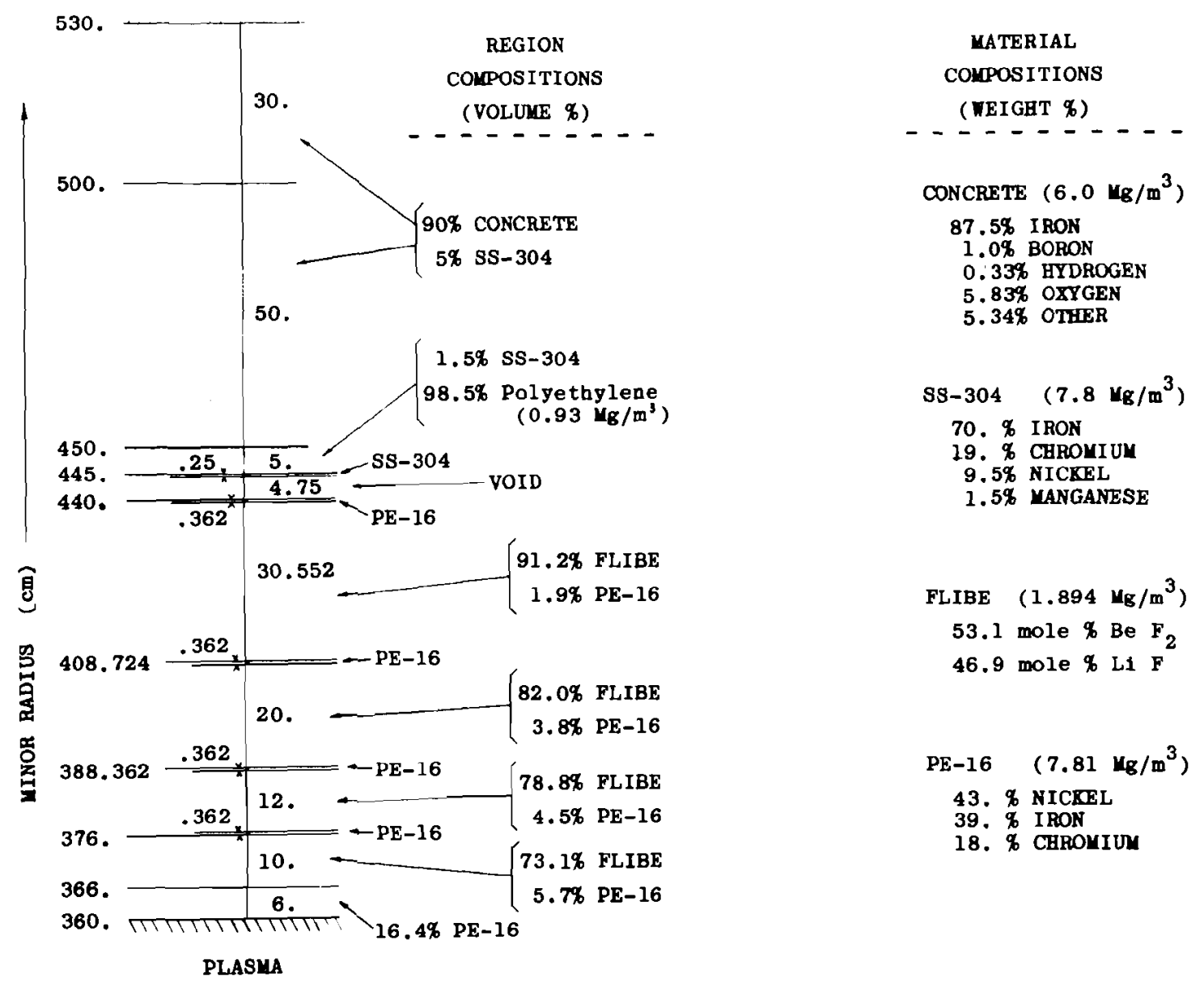

FIGURE 44 Schematic Representation of the Layered Blanket Model 
The reactor will be constructed of 24 sectors of $15^{\circ}$ each. Each section of the blanket will contain roughly 48 metric tons of $P E-16$ and 280 metric tons of flibe.

Radiation induced embrittlement of PE-16 limits the lifetime of blanket structure. At the first wall loading of $1.76 \mathrm{MW} / \mathrm{m}^{2}$, embrittlement is expected to require replacement of segments of the blanket after 5 years in the reactor.

It is planned to replace $1 / 5$ of the blanket each year. This includes the blanket structures and cooling tubes, the vacuum wall, and its inner radiation shield. The yield of PE-16 structural material ( $43 \% \mathrm{Ni}, 37 \% \mathrm{Fe}, 18 \% \mathrm{Cr}$ ) is 220 metric tons per year, to be compacted into a volume of $34 \mathrm{~m}^{3}$. The rate of afterheat production in this material shortly after shutdown is expected to be about $10 \mathrm{MW}$ due to $2 \times 10^{9} \mathrm{Ci}$ of radioactive decay $\left({ }^{57} \mathrm{Co},{ }^{55} \mathrm{Fe},{ }^{60} \mathrm{Co},{ }^{54} \mathrm{Mn}\right.$ and ${ }^{63} \mathrm{Ni}$ activities dominate). One year after shutdown the rate of afterheat production will be $800 \mathrm{~kW}$. It is anticipated that this material will be stored onsite in a cooled vault.

Corrosion of PE-16 structure by flibe coolant will preferentially remove chromium. Each year an undefined flibe cleanup system will remove 12 metric tons of $c r$ and 0.3 metric ton each of niobium and iron from the flibe. This material, in oxide and fluoride forms, will require about $45 \mathrm{~m}^{3}$ of storage space. An initial activity of $37 \mathrm{MCi}$ is expected, but only $1 \mathrm{MCi}$ will be due to isotopes with half lives exceeding 1 year $\left({ }^{55} \mathrm{Fe}\right.$ and $\left.{ }^{60} \mathrm{Co}\right)$. Onsite storage in a cooled vault is planned.

Heat Transfer System for the PPPL Tokamak - Helium gas is the primary coolant. The heat absorbed in the blanket is carried to external steam generators where it is used to raise high pressure steam to drive the turbine-generators (Figure 45 ).

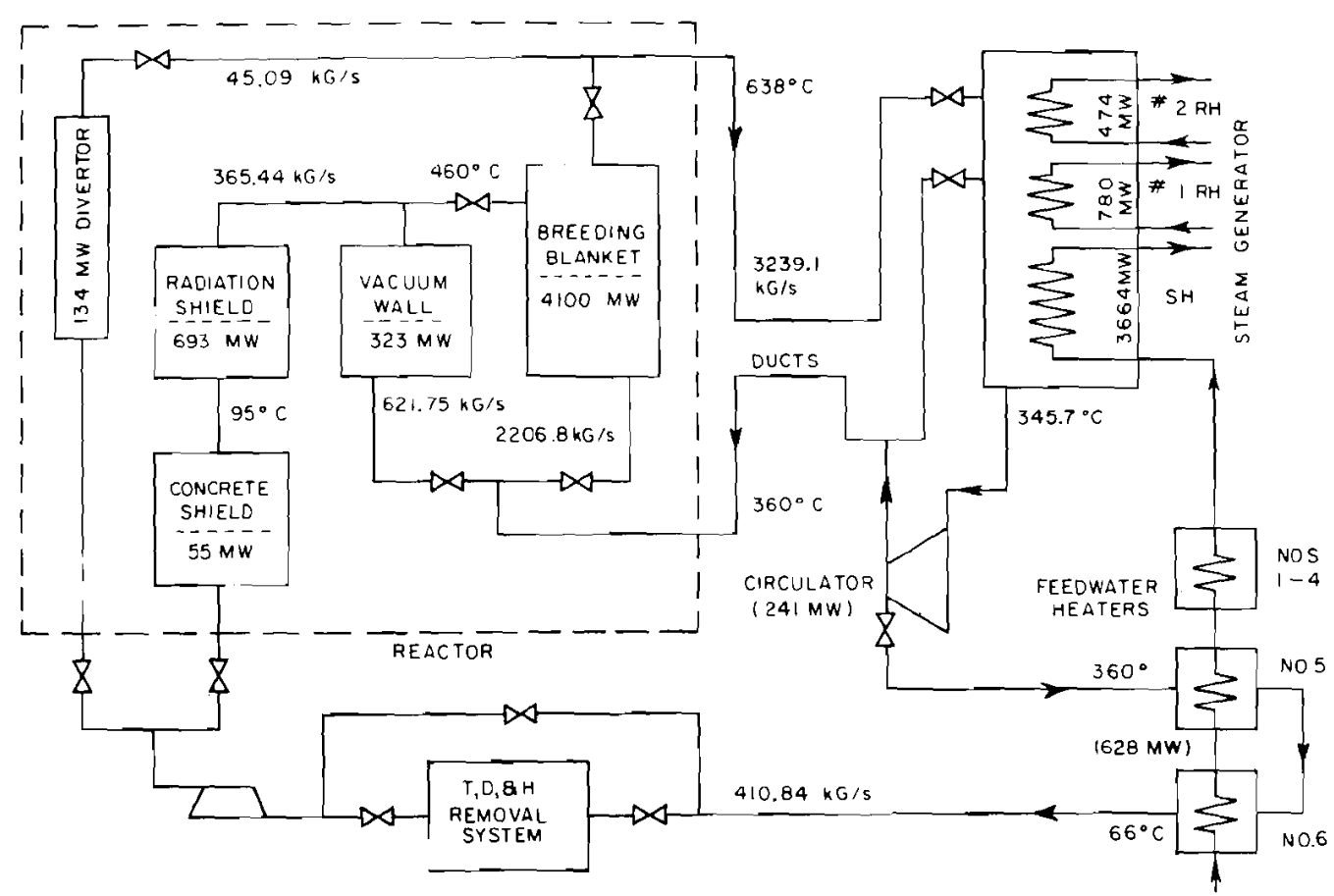

FIGURE 45 The Hel ium Coolant System of the PPPL Design 
The design requires $4 \times 10^{4} \mathrm{~kg}$ of helium coolant which is circulated with a mass flow rate of $1.2 \times 10^{7} \mathrm{~kg} / \mathrm{hr}$. Parallel loop flows are not used in the design; the helium flows from the reactor to the steam generator building in a single large duct. This is illustrated in Figure 46 which also shows the ring ducts located beneath the reactor floor and which connect each of the blanket modules to the main transfer duct. The 12 steam generators which are supplied by the main transfer duct are also indicated.

The main helium coolant stream enters the reactor at a temperature of $360^{\circ} \mathrm{C}$ and a pressure of $53 \mathrm{~kg} / \mathrm{cm}^{2}$; it leaves at $638^{\circ} \mathrm{C}$ and $50 \mathrm{~kg} / \mathrm{cm}^{2}$. It flows through main and branch inlet headers to the serpentine tubes, which it follows as it absorbs heat from the flibe in the blanket. The temperature profile along a nominal cooling tube in the blanket is shown in Figure 47.

After passing through the blanket cooling tubes the helium flows through outlet headers and downcomers to the ring ducts, the main transfer duct, and then to the steam generators. Circulators

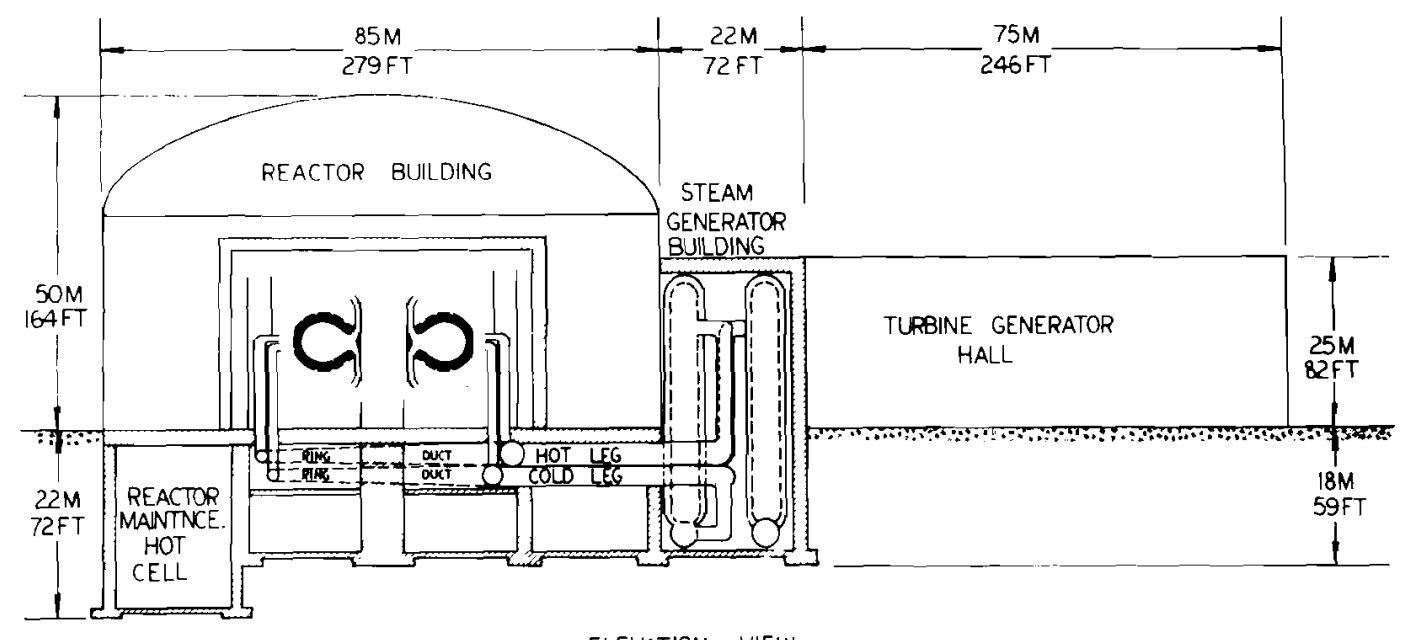

ELEVATION VIEW

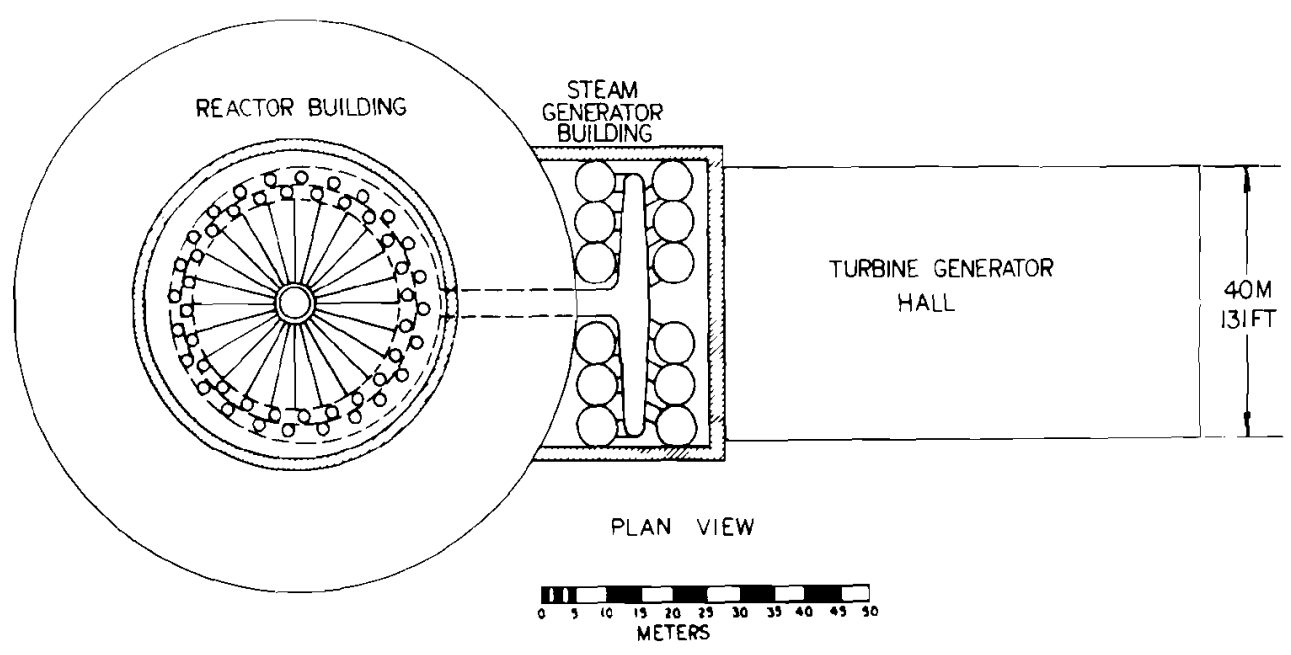

FIGURE 46 The PPPL Tokamak Plant 


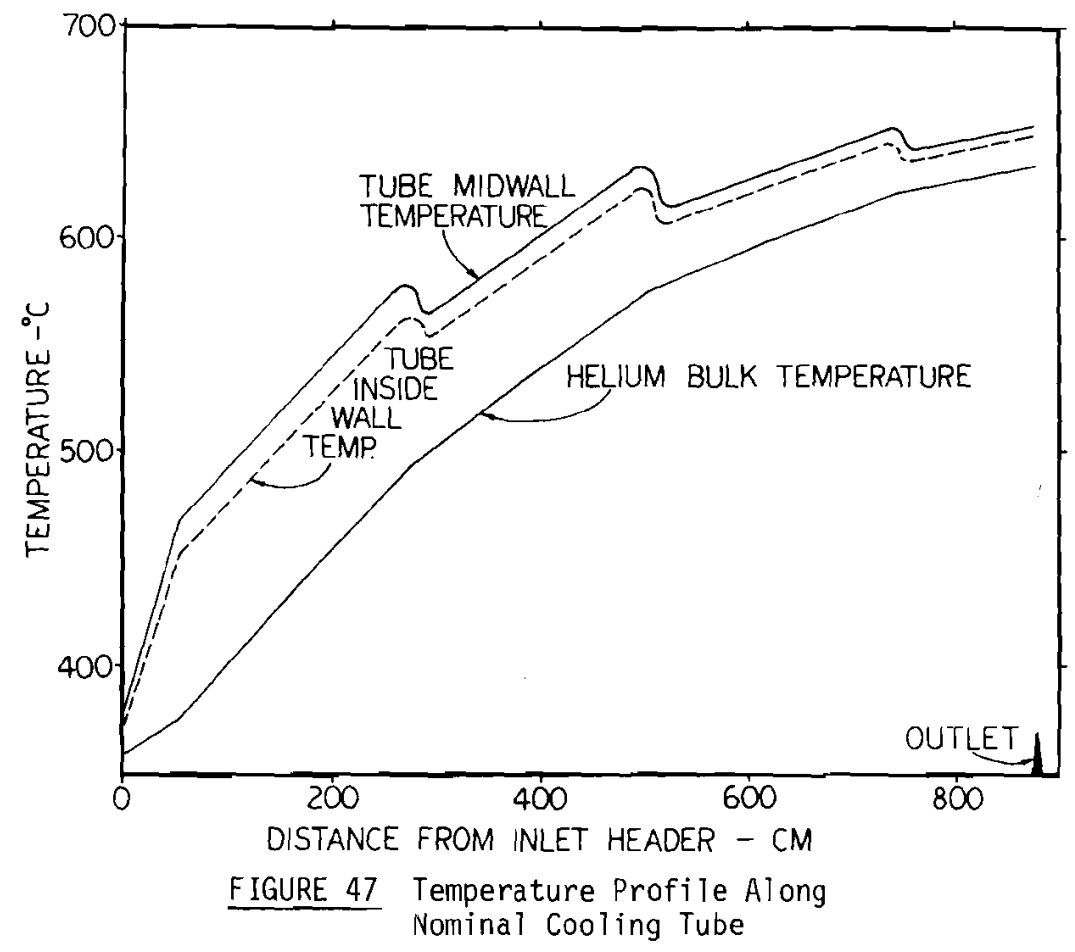

located at the lower end of each of the steam generators return the helium to the reactor. Parameters of the main ducts and headers are listed in Tables 10 and 11.

TABLE 10 Hot Leg Duct Parameters

\begin{tabular}{|c|c|c|c|c|}
\hline Section & $\begin{array}{r}\text { Tota } 1 \\
\text { Number } \\
\end{array}$ & $\begin{array}{c}\text { Inside } \\
\text { Diameter, } \\
\mathrm{cm} \\
\end{array}$ & $\begin{array}{c}\text { Length, } \\
\mathrm{m}\end{array}$ & $\begin{array}{c}\text { Pressure } \\
\text { Drop, } \\
\text { atm } \\
\end{array}$ \\
\hline Downcomer & 24 & 150 & 16.7 & \\
\hline Half of Ring Header & 2 & $\begin{array}{r}\text { varies } \\
150 \rightarrow 366\end{array}$ & 54.0 & \\
\hline $\begin{array}{l}\text { Duct to Steam } \\
\text { Generator Bldg. }\end{array}$ & 1 & 366 & 31.7 & \\
\hline $\begin{array}{l}\text { Duct to Steam } \\
\text { Generator Risers }\end{array}$ & 2 & $315+200$ & 18.0 & \\
\hline $\begin{array}{l}\text { Risers to Steam } \\
\text { Generators }\end{array}$ & 12 & 200 & 23.0 & \\
\hline
\end{tabular}

A portion, less than $1 \%$, of the return helium flow is diverted through a cleanup loop which removes isotopes of hydrogen. The coolant helium contains oxygen at a partial pressure of $5 \times 10^{-3}$ atmospheres, which reacts with hydrogen entering the system to form water. This is removed in the cleanup loop by passing the helium through a commercial molecular sieve drying agent. Since this must be done at low temperatures, the helium is first cooled to $66^{\circ} \mathrm{C}$ by passing it through feedwater heaters. The helium exiting from this loop is used to cool the reactor magnet shield and divertor before returning to the main coolant stream. 
TABLE 11 Cold Leg Duct Parameters

\begin{tabular}{|c|c|c|c|c|}
\hline Section & $\begin{array}{r}\text { Total } \\
\text { Number } \\
\end{array}$ & $\begin{array}{c}\text { Inside } \\
\text { Diameter, } \\
\mathrm{cm} \\
\end{array}$ & $\begin{array}{c}\text { Length, } \\
\mathrm{m} \\
\end{array}$ & $\begin{array}{c}\text { Pressure } \\
\text { Drop, } \\
\text { atm } \\
\end{array}$ \\
\hline Risers from Circulators & 12 & 180 & 10.0 & \\
\hline $\begin{array}{l}\text { Duct from Circulator } \\
\text { Risers }\end{array}$ & 2 & $180 \rightarrow 280$ & 18.0 & \\
\hline Duct to Ring Header & 1 & 325 & 31.7 & \\
\hline Half of Ring Header & 2 & $325 \rightarrow 135$ & 54.0 & \\
\hline Riser to Reactor & 24 & 135 & 16.7 & \\
\hline
\end{tabular}

The design requires 12 supercritical, double reheat steam generators in parallel service. Each unit is $117 \mathrm{ft}$ in height and $12.5 \mathrm{ft}$ in diameter with an electric motor driven single stage axial flow helium circulator mounted at the base. Design of the units is based on present day technology used in the HTGR program. High temperature helium from the blanket is admitted to each steam generator through a 9-ft diameter duct that directs a portion of the gas flow upward over the second reheater and allows the remainder to pass downward over the first reheater. The gas flows recombine below the first reheater and continue downward over the supercritical fluid coil and into the helium circulators. In one pass through the steam generators, the helium temperature drops $292^{\circ} \mathrm{C}$ and its pressure drops $10.1 \mathrm{psi}$.

Feedwater is admitted to the lower section of each steam generator at $294^{\circ} \mathrm{C}$, passes upward through the helically wound supercritical coil and exits to the turbine at $538^{\circ} \mathrm{C}$ and $260 \mathrm{~kg} / \mathrm{cm}$. Steam flows to the first and second reheaters enter the upper level of each steam generator and also exit to the turbine at $538^{\circ} \mathrm{C}$. The total steam flow produced by the 12 steam generators is $17.8 \times 10^{6} \mathrm{~kg} / \mathrm{hr}$.

The steam generators are fabricated of incoloy 800 . Tubesheets are located outside the helium pressure vessel for maintenance accessibility. Inspection of each unit is possible through a central core pipe. All heat exchanger surfaces are helically wound with the exception of the second reheater, which is of vertical tubular arrangement. All helically wound surfaces transport their fluids in counter flow to the helium passing over them. The surface area of the supercritical coils is $6.8 \times 10^{4} \mathrm{~m}^{2}$. Surface areas of the first and second reheater coils are $1.1 \times 10^{4}$ and $8.9 \times 10^{3} \mathrm{~m}^{2}$.

Electricity Generation System for the PPPL Design - Electricity is generated by a cross-compound arrangement of steam turbines which drive the shafts of two $3600 \mathrm{rpm}, 26 \mathrm{kV}$ generators. This turbine-generator system is within the current state-of-the-art. Each of the two generator shafts is approximately $200 \mathrm{ft}$ long, and is driven by four double-flow turbines arranged in tandem. Superheated steam flows from the steam generator superheater (SH) at a rate of $6.6 \times 10^{6} \mathrm{~kg} / \mathrm{hr}$. It flows first to the very high pressure (VHP) turbine, located on the high pressure shaft. Steam exiting the VHP turbine is reheated in the steam generator (\#IRH) and is sent to the high pressure (HP) turbine on the low pressure shaft. Steam exiting the HP turbine 
is again reheated in the steam generator (\#2RH). The flow is then split, and used to drive one intermediate pressure (IP) turbine and two low pressure (LP) turbines on each shaft. Flow parameters are shown on Figure 48.

Steam is extracted variously from the VHP, HP and IP turbines to heat feedwater for the steam generator, and to spin the turbines which drive the boiler feed pumps (BFP) that pump the feedwater through the heaters into the steam generator. Most of the steam $\left(4.7 \times 10^{6} \mathrm{~kg} / \mathrm{hr}\right)$ passes through the turbines and is condensed at a pressure of 1.2 psia and a temperature of $43^{\circ} \mathrm{C}$, for return to the steam generator as feedwater.

The generators on the high and low pressure shafts produce gross electrical outputs of 1235 and 1170 MWe, respectively. Of the total gross output (2405 MWe), 375 MWe is used as follows: helium circulators, $251 \mathrm{MW}$; cryogenic refrigerators, $100 \mathrm{MW}$; cooling tower fans, $15 \mathrm{MW}$; miscellaneous, $9 \mathrm{MW}$. The net plant output is thus 2030 MWe, produced from 5305 MWt. The gross thermal efficiency of generation is $45 \%$, and the net plant efficiency is $38 \%$. The net heat rate is $8917 \mathrm{Btu} / \mathrm{kWh}$. The energy flow schematic for the power plant is shown in Figure 49.

Wet-dry cooling towers are used for the dissipation of waste heat. Wet-dry towers are chosen to el iminate the objectionable vapor plume of wet cooling towers under certain weather conditions.

Spent Plasma Collection System for the PPPL Tokamak - The partially burned fuel escaping from the plasma is collected in the divertor $(5.5 \mathrm{~kg} /$ day of tritium, $3.6 \mathrm{~kg} /$ day of deuterium and $0.7 \mathrm{~kg} /$ day of helium).

The reactor has two divertor collection chambers, one above and one below the torus centerline (Figure 50). Plasma particles diffusing farther from the plasma axis than the magnetic flux separatix (the "scrapeoff" plasma) are diverted by the outer field lines into the collection chambers. The $80 \mathrm{~cm}$ wide divertor channels closely follow the magnetic flux surfaces for $8 \mathrm{~m}$, then flare into exhaust chambers approximately $2 \mathrm{~m}$ by $10 \mathrm{~m}$.

As the scrapeoff plasma flows into and through the divertor channels it cools via radiation and via interactions with atoms of neutralized plasma. The cooling results in deionization with subsequent radiation of the recombination energy to the walls. Deionization takes place at the entrance to the exhaust chamber, and neutral gas is removed by vacuum pumps.

The scrapeoff plasma pressure is about 1 torr, and the exhaust chamber pressure is $4.5 \times 10^{-4}$ torr. This pressure difference is supported by the deionization region and results in supersonic flow of neutral gas into the exhaust chamber. A particle throughput of $3 \times 10^{22}$ molecules per second is expected, requiring a pumping speed of $6.7 \times 10^{5} 1 \mathrm{iters} /$ second. This pumping speed is also sufficient to provide adequate evacuation of the spent plasma from the plasma chamber between thermonuclear burns. It is achieved by 96 mercury diffusion pumps manifolded to the divertor exhaust chambers. The pumps are evenly divided between the top and bottom vacuum manifolds, and are equally spaced around the reactor.

The diffusion pumps use mercury as the working fluid because mercury is not affected by beta radiation from tritium. The diffusion pumps are backed up by mercury ejector pumps which provide a 100 torr forepressure for the multistage compressors in the fuel system. 


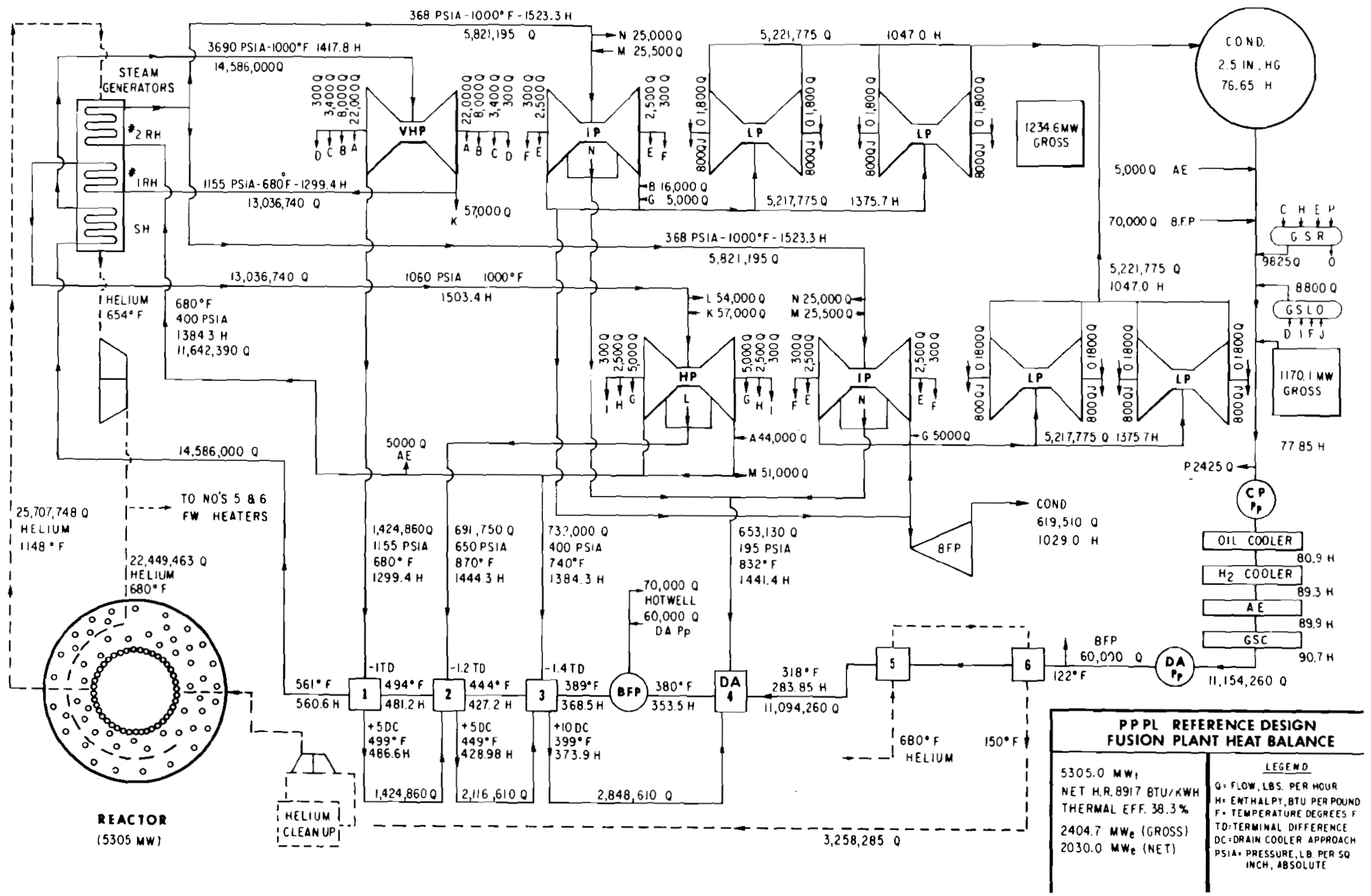

FIGURE 48 Flow Diagram for the PPPL Turbine-Generators at Full Load 


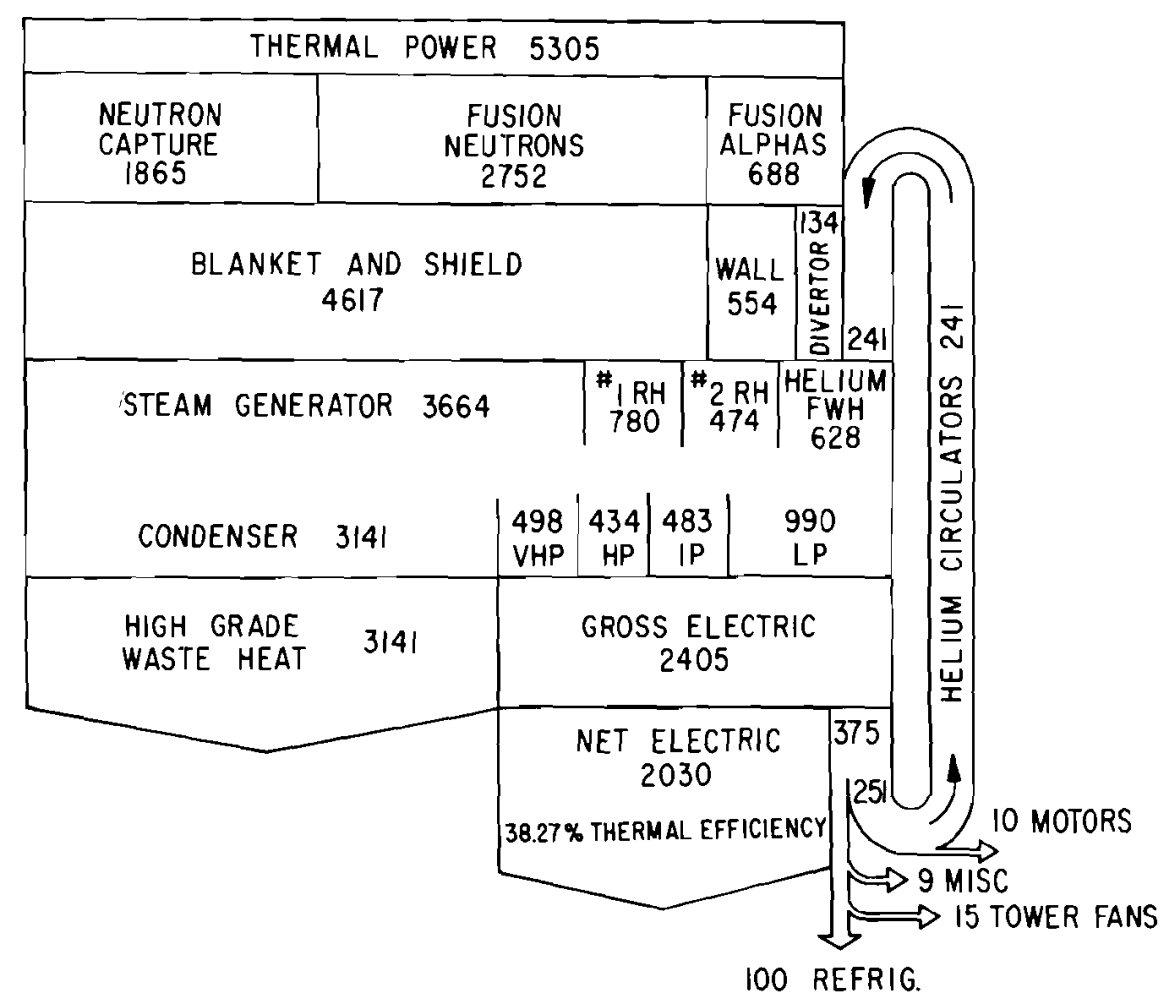

FIGURE 49 Energy Flow Schematic of the PPPL Design

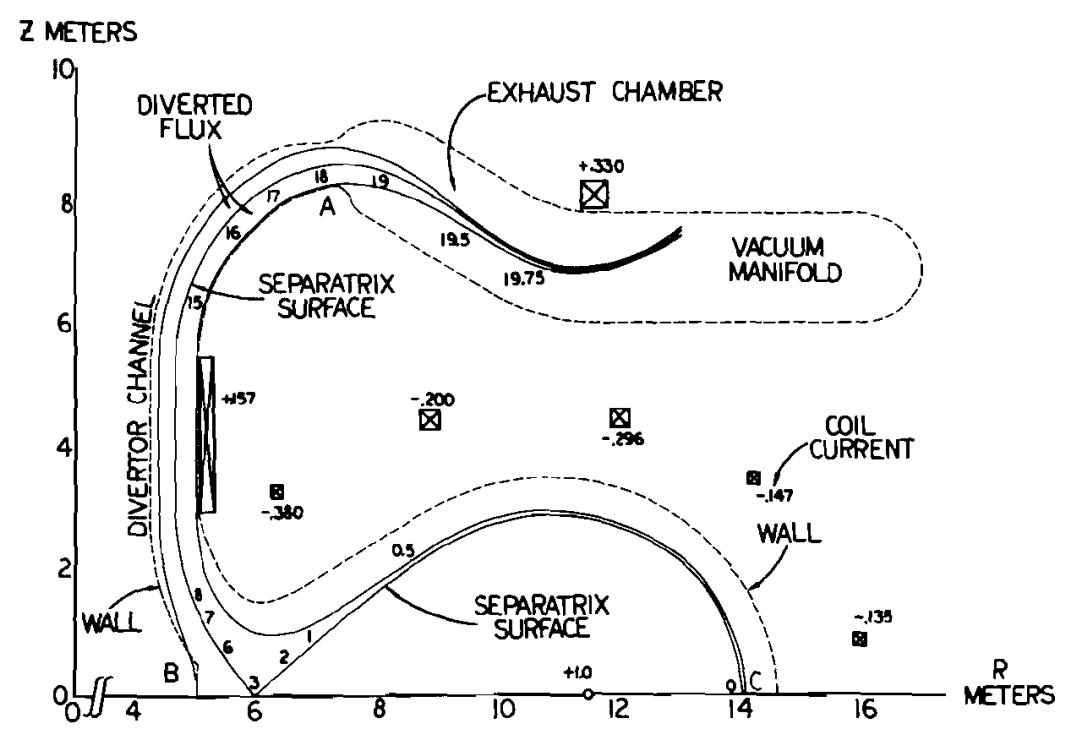

FIGLIRE 50 Divertor Magnetic Flux Surfaces in the PPPL Tokamak

Energy is deposited on the walls of the divertor at a rate of 134 MWt, primarily due to 1 ine radiation from the argon in the plasma. The walls of both the entrance channel and the exhaust chamber are cooled by tubes carrying helium coolant. The arrangement is similar to the radiation shield for the plasma chamber first wall except that due to lower heat fluxes, the tubes are 
thermally connected to the wall surfaces. The helium coolant is expected to leave the divertor at the blanket outlet temperature of $638^{\circ} \mathrm{C}$, for direct routing to the steam generators (Figure 45).

Bred Tritium Recovery System for the PPPL Design - The breeding ratio of tritium in the blanket flibe is 1.04 . The $0.55 \mathrm{~kg} /$ day which is bred is recovered by outgassing it from the flibe in the form of tritium fluoride (TF), condensing the TF in cold traps, and then electrolyzing it in solution with potassium fluoride (KF) to $T_{2}$ and $F_{2}$. The flibe is circulated from the blanket to the recovery system (Figure 51 ).

The flibe is processed at the blanket temperature of $660^{\circ} \mathrm{C}$. It is circulated continuous $7 y$ to eight evacuated disengager tanks which operate in parallel and are arranged around the periphery of the reactor. The total flibe flow rate is $4 \times 10^{6} \mathrm{~kg} / \mathrm{hr}$. The $\mathrm{flibe} i \mathrm{~s}$ sprayed into the top of the evacuated tanks ( $1 \mathrm{~m}$ diameter $\times 3 \mathrm{~m}$ high) and the TF outgasses from the resulting shower of droplets.

The disengager tanks are maintained at a pressure of $4 \times 10^{-4} \mathrm{~atm}$, and a total of $29 \mathrm{moles} / \mathrm{hr}$ of gasses are drawn off. These include TF, flibe vapor, and helium from blanket $n, \alpha$ reactions, including tritium breeding. This process is expected to hold concentration of tritium in the blanket flibe to a mole fraction of $2.7 \times 10^{-7}$.

The gasses drawn from the disengager are cooled, and the flibe vapor is condensed in water-cooled traps. The TF is then condensed in liquid nitrogen-cooled traps, and the non-condensable gasses are sent to the helium storage system. Two trap units operating alternately collect the ff from each disengager tank; thus eight traps are operating simultaneously. The traps are alternated, with staggered 24 hour periods. Thus one is melting out every 3 hour.

The TF from the traps is introduced into electrolysis cells containing KF. The electrolysis of $\mathrm{TF}$ in solution with $\mathrm{KF}$ is rapid at moderate temperatures, yielding tritium at one electrode and

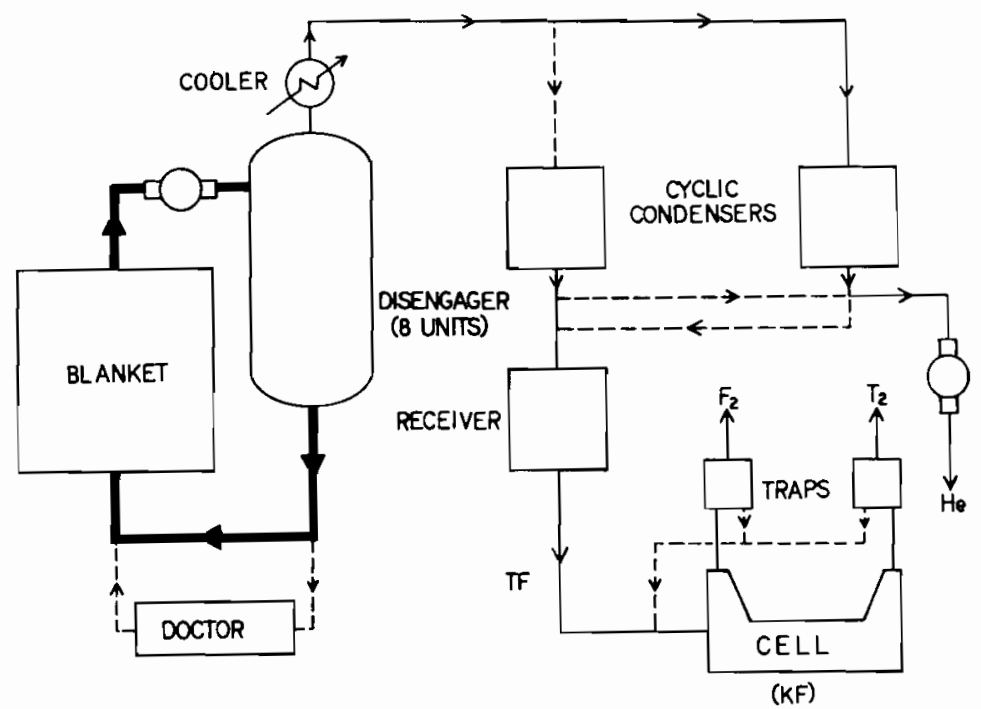

FIGURE 51 Salt Processing System in the PPPL Design 
fluorine at the other. The evolved gasses are cold trapped to remove vaporized TF, and the tritium is sent to the fuel system. The "doctor" system indicated in Figure 51 maintains the desired purity and composition of the salt. It includes filters and perhaps chemical reactors or electrolytic cells.

Tritium permeates from the flibe into the helium primary coolant, from which it is recovered to minimize permeation rates into the steam system. The recovery system is sized to recover $36 \mathrm{~g} /$ day, although this is 100 times higher than is expected to be required.

0xygen is added to the helium primary coolant to tie up tritium as water and maintain a partial pressure of tritium in the helium below $10^{-12}$ torr. Consequently, tritium recovery from the helium is accomplished by adsorbing the water on a molecular sieve drying agent, evolving it by heating the drying agent in a vacuum chamber, cold trapping the water, and then electrolyzing it (Figure 52). Two drying columns are operated alternately on a daily cycle. The columns are $1 \mathrm{~m}$ in diameter by $1 \mathrm{~m} \mathrm{high,} \mathrm{and} \mathrm{process} 5 \times 10^{3} \mathrm{~kg} / \mathrm{hr}$ of helium. These dryers are expected to hold the partial pressure of tritiated water in the helium coolant to $10^{-5}$ atmospheres.

The tritium inventory of the plant is estimated to be $2.57 \mathrm{~kg}$, of which $2.02 \mathrm{~kg}$ is in storage. The inventory is described in Table 12. Tritium flows in the plant are indicated in Figure 53.

Containment Building for the PPPL Tokamak - The cylindrical reactor building is $85 \mathrm{~m}$ in diameter, and its domed top rises $50 \mathrm{~m}$ above grade. The reactor building (Figure 32 ) is designed to withstand the overpressure and temperature $\left(29 \mathrm{psig}\right.$ and $200^{\circ} \mathrm{C}$ ) expected from a rupture of a main helium heat transfer duct. These conditions are similar to those that current nuclear plant containments are designed to withstand, so that detailed design and construction should pose no special problems.

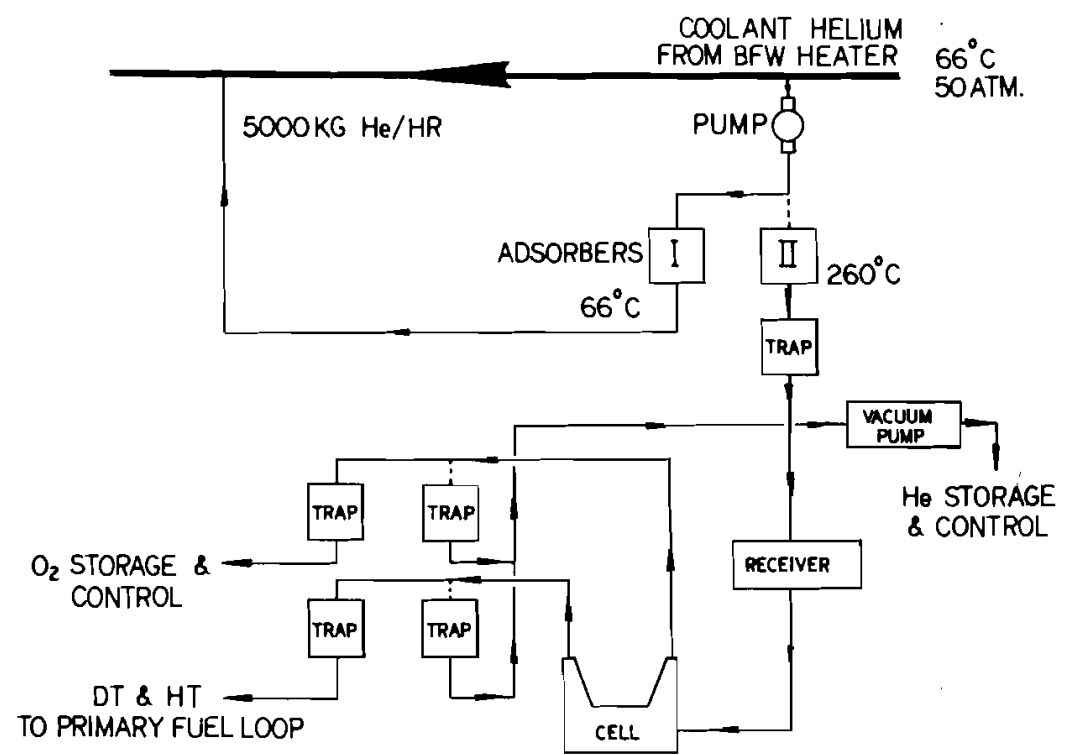

FIGURE 52 Fuel Recovery System on Coolant Helium Loop in the PPPL Tokamak 
TABLE 12 The PPPL Tokamak Tritium Inventory $(a)$

$\begin{array}{lc} & \begin{array}{c}\text { Tritium } \\ \text { (grams) }\end{array} \\ \text { Blanket flibe } & 10 \\ \text { Dissolved in structure } & 30 \\ \text { Helium primary coolant } & 7 \\ \text { Fuel System } & \underline{505} \\ \quad \text { Plant Active Inventory } & 552 \\ \quad \text { Storage } & \underline{2020} \\ \text { Total Plant Tritium Inventory } & 2572\end{array}$

a. The tritium stored is 3.8 times the daily consumption rate and $1 / 3$ of the daily injection rate.

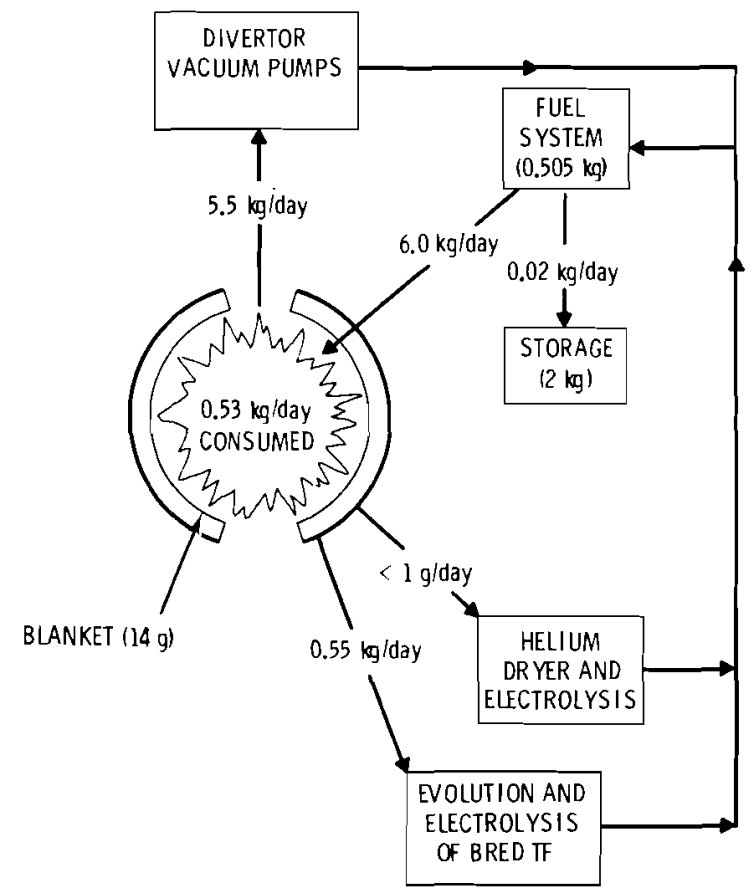

\section{FIGURE 53 Tritium Flow and Inventory Schematic of the PPPL Design}

Within the reactor building, all pipes carrying high temperature fluids containing tritium (e.g., helium primary coolant) are doubled walled, with a helium purge between the walls. A low pressure helium purge is also maintained between the reactor blanket and shield. By these means the tritium leakage into the reactor building atmosphere is to be maintained at very low levels during normal operation. Should leakage to the building atmosphere exceed safe levels, access will be restricted and the tritium will be removed by oxidizing it to water and drying the air. 


\subsubsection{ORNL Tokamak}

Summary Discription - The ORNL Tokamak power plant (Figure 54) produces 518 MWe of net electrical power from a thermal energy release of $1000 \mathrm{MWt}$. The generation cycle coincides with the thermonuclear burn cycle, which is 172 seconds long and includes a 20 second shutdown for refueling.

The reactor is cooled by molten lithium metal which also functions as a neutron moderator and fertile material to breed tritium fuel. Heat from this primary coolant is used to boil potassium intermediate coolant. The potassium vapor drives a topping turbine, then is condensed in steam generators that produce steam at $566^{\circ} \mathrm{C}$ and $282 \mathrm{~kg} / \mathrm{cm}^{2}$ to drive the turbine-generators. Major power plant systems are identified and their functional relations are indicated in Figure 55.

The reactor is located within the evacuated containment building shown in Figure 54 . Potassium vapor is piped from the reactor to the topping turbine through steel-lined, hermetically-sealed ducts beneath the floor of the evacuated reactor cell. The diameter of the reactor is $30 \mathrm{~m}$. The major and minor radii of its toroidal plasma chamber are 10.5 and $3.5 \mathrm{~m}$. It is constructed primarily of niobium structural material.

The toroidal field primarily responsible for plasma confinement is produced by 48 coils constructed of niobium-titanium superconductor stabilized with copper. These coils have a bore diameter of $11 \mathrm{~m}$. Maximum and plasma center magnetic fields are 5.3 and $2.5 \mathrm{~T}$, respectively. Plasma stability is maintained by additional magnetic fields produced by the plasma current and by nonsuperconducting poloidal field coils.

During reactor startup the plasma current is established by transformer action of the poloidal field coils. An iron core is located in the central region of the torus to enhance this effect. Divertor coils are not used in this design.

The plasma is heated ohmically by the plasma current of $10 \mathrm{MA}$. However, to achieve ignition and to maintain the plasma temperature during the thermonuclear burn requires the continuous injection of neutral atom beams carrying $10 \mathrm{MW}$ of power. These beams also supply the entire fue 1 requirements of the plasma. The projected injection of 504 amperes equivalent of $20 \mathrm{keV}$ neutral atoms represents a considerable extension of existing technology.

The plasma contains equal numbers of deuterium and tritium atoms. The plasma chamber fue 1 charge is $0.7 \mathrm{~g}$ of tritium and $0.5 \mathrm{~g}$ of deuterium. Its ion temperature is $20 \mathrm{keV}$.

The neutra 1 beam injectors supply fuel to the plasma at the rate of $0.6 \mathrm{~kg} /$ day of tritium and $0.4 \mathrm{~kg} /$ day of deuterium. Of this, $20 \%$ is burned before the burn is terminated, yielding a fue 1 consumption rate of $0.12 \mathrm{~kg} /$ day of tritium and $0.08 \mathrm{~kg} /$ day of deuterium. Unburned fuel is purified by cryogenic distillation and recycled to the plasma.

Energy collection and tritium breeding take place in a $100 \mathrm{~cm}$ thick blanket located inside the magnet coils, adjacent to the plasma. Further attenuation of particles and radiation is provided by an $88 \mathrm{~cm}$ thick shield located between the blanket and the superconducting magnets (Figure 56). 


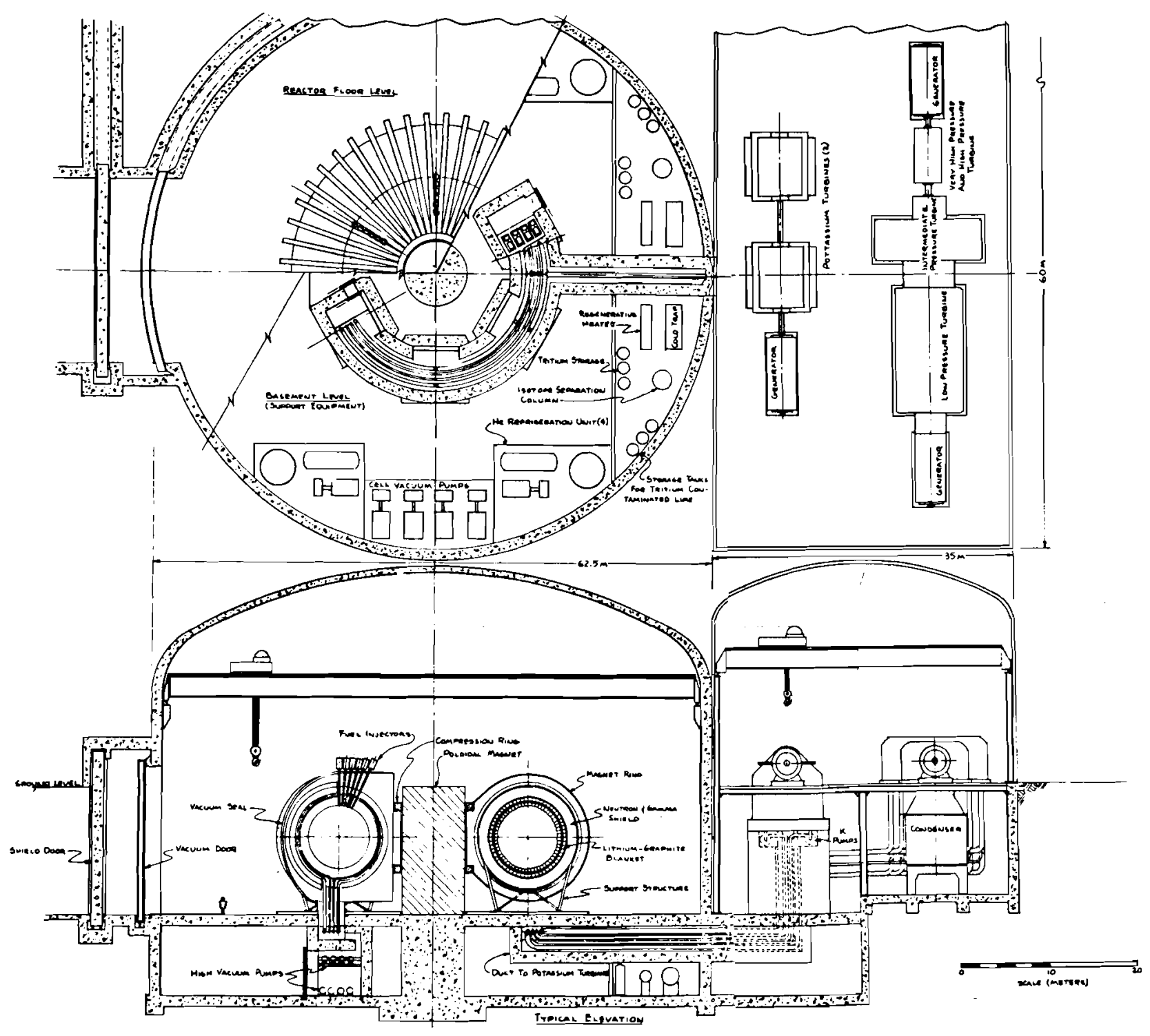

FIGURE 54 Section View of the ORNL Tokamak Power Plant

The blanket is constructed of $\mathrm{Nb}-1 \% \mathrm{Zr}$ and contains liquid lithium metal coolant and graphite neutron moderator. It is composed of individual curved segments (Figure 56). The innermost $30 \mathrm{~cm}$ of the blanket segments is a lithium flow channel. It is followed by $39 \mathrm{~cm}$ of graphite and a lithium flow return channel $30 \mathrm{~cm}$ deep. The toroidal blanket is composed of six separate $60^{\circ}$ sectors.

Radiation damage to the niobium structure requires replacement of blanket segments after 10 years in the reactor. This results in an average rate solid waste production of 124 metric tons per year.

A single lithium/potassium/steam coolant loop removes heat from the blanket. The lithium is circulated within the blanket by electromagnetic pumping, and is allowed to reach $1052^{\circ} \mathrm{C}$ due to the 


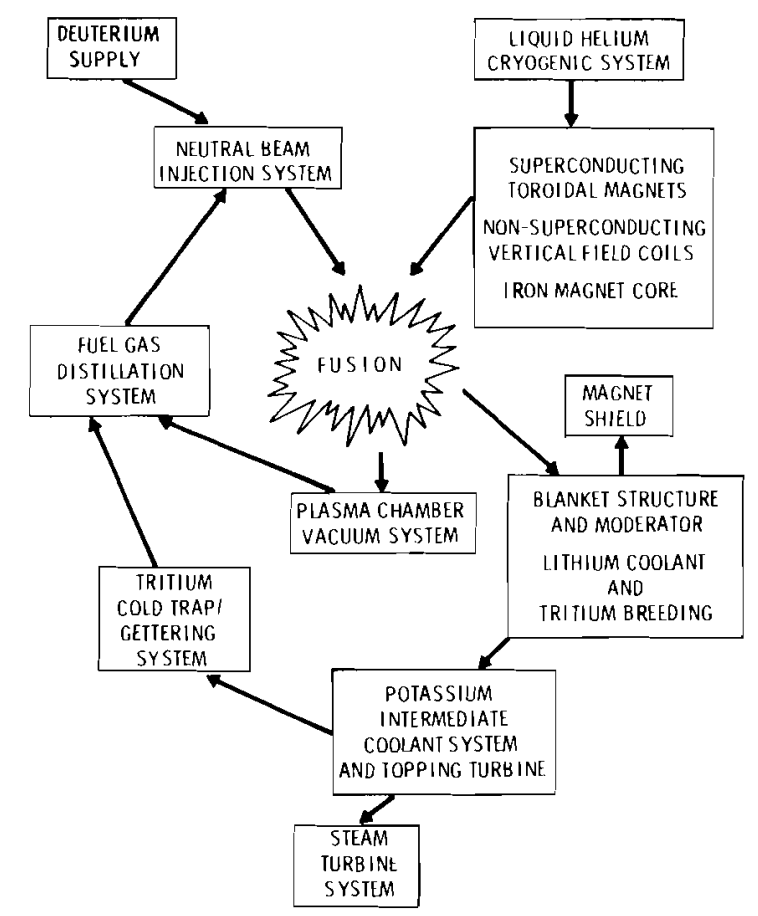

FIGURE 55 Functional Relations Between Systems of the ORNL Tokamak

high temperature properties and corrosion resistance of the niobium structure. Heat from the lithium is used to boil potassium in tube banks within the blanket. This produces vapor at $982^{\circ} \mathrm{C}$ which drives a topping turbine and is condensed in a steam generator, producing steam at $566^{\circ} \mathrm{C}$.

Electricity is generated by the potassium vapor turbine-generator and by a cross-compound steam turbine-generator arrangement. The thermal efficiency of generation is $56 \%$, and the net plant efficiency is $52 \%$.

Spent fuel is collected by vacuum pumps between burn cycles. The collection rate is $0.5 \mathrm{~kg} / \mathrm{day}$ of tritium, $0.3 \mathrm{~kg} /$ day of deuterium and $0.16 \mathrm{~kg} /$ day of helium. About $0.16 \mathrm{~kg} /$ day of tritium is bred in the lithium coolant/fertile material at a breeding ratio between 1.3 and 1.4 . It is allowed to permeate into the potassium intermediate coolant and is recovered from a side stream from the potassium condensate tank. Liquid lithium dissolved in the potassium getters the tritium, and the resulting lithium tritide is collected in filtered cold traps.

The total plant inventory of tritium is $6.0 \mathrm{~kg}$, of which $5.6 \mathrm{~kg}$ is in storage. Of the active inventory, $375 \mathrm{~g}$ is in the primary coolant, $21 \mathrm{~g}$ is in the niobium structure, and $0.2 \mathrm{~g}$ is in the potassium intermediate coolant.

Plasma Confinement System for the ORNL Design - Toroidal and poloidal magnets are used. ${ }^{(7)}$ It is assumed that divertor coils are not necessary. The poloidal coils provide the vertical fields necessary to stabilize the position of the plasma ring and to induce the 10 MA plasma current. The transformer action of the poloidal coil is assisted by an iron core located in the central region of the torus, along its major axis. 


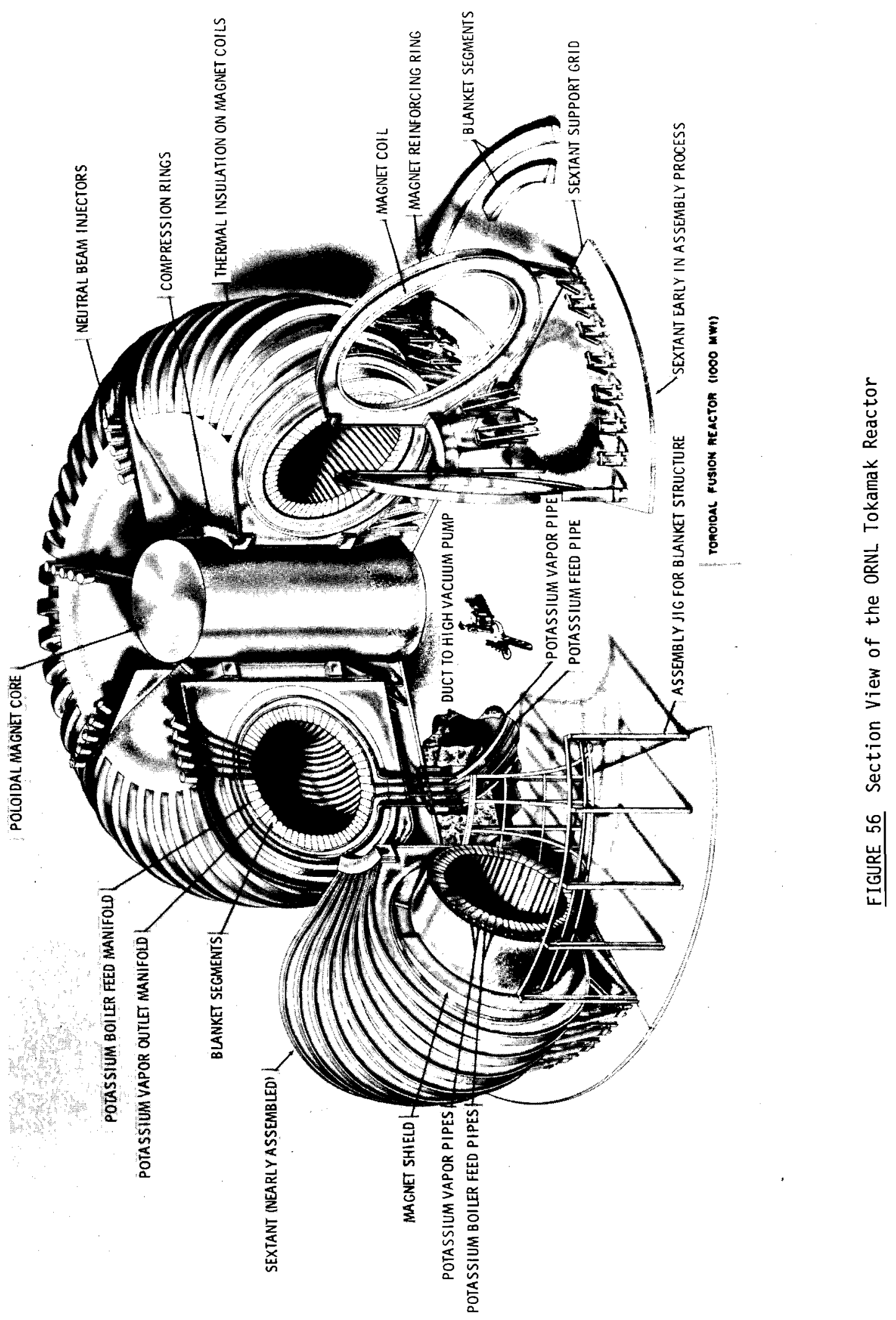


The toroidal field coils are constructed of niobium titanium superconductor stabilized with copper. Liquid helium cooling maintains the superconductor at $4^{\circ} \mathrm{K}$. The poloidal magnet coils will be superconducting. They will be made of copper and cooled by water.

The toroidal field is produced by 48 circular coils evenly spaced around the torus. Forces tending to distort the coils are supported by massive reinforcing rings of I-beam cross section as shown in Figure 57. (Box cross section has also been suggested to better support lateral forces in the event of an accidental quenching of one or more coils.) The superconductor is wound on a bobbin which is welded to the inner flange of the supporting ring. Each coil assembly weighs 62 metric tons. The coils are supported against their weight and against the large magnetic forces which push them toward the major axis of the torus by massive compression rings of $80 \mathrm{~cm}^{2}$ cross section (Figure 57).

The superconductor is wound in 11 turn disks inside the bobbin. Each bobbin contains 63 disks $0.6 \mathrm{~cm}$ thick, which are separated by channels for the flow of liquid helium coolant. Each coil carries an equivalent current of $2.8 \mathrm{MA}$ at an average current density of $4.8 \mathrm{kA} / \mathrm{cm}^{2}$. The toroidal field at the plasma center is $2.5 \mathrm{~T}$, and the maximum field at the superconductor is $5.3 \mathrm{~T}$. The dewars which contain the liquid helium coolant and evacuated superinsulation form a continuous toroidal surface in the central region where the coils nearly touch. Toward the outer perimeter of the torus where the coil separation exceeds $15 \mathrm{~cm}$, dewar area is reduced by enclosing only the coils in the dewars (Figure 56).

The poloidal field coils will be located inside the toroidal field coils. Since they are not superconducting they are mounted within the magnet shield tank, along the inner surface adjacent
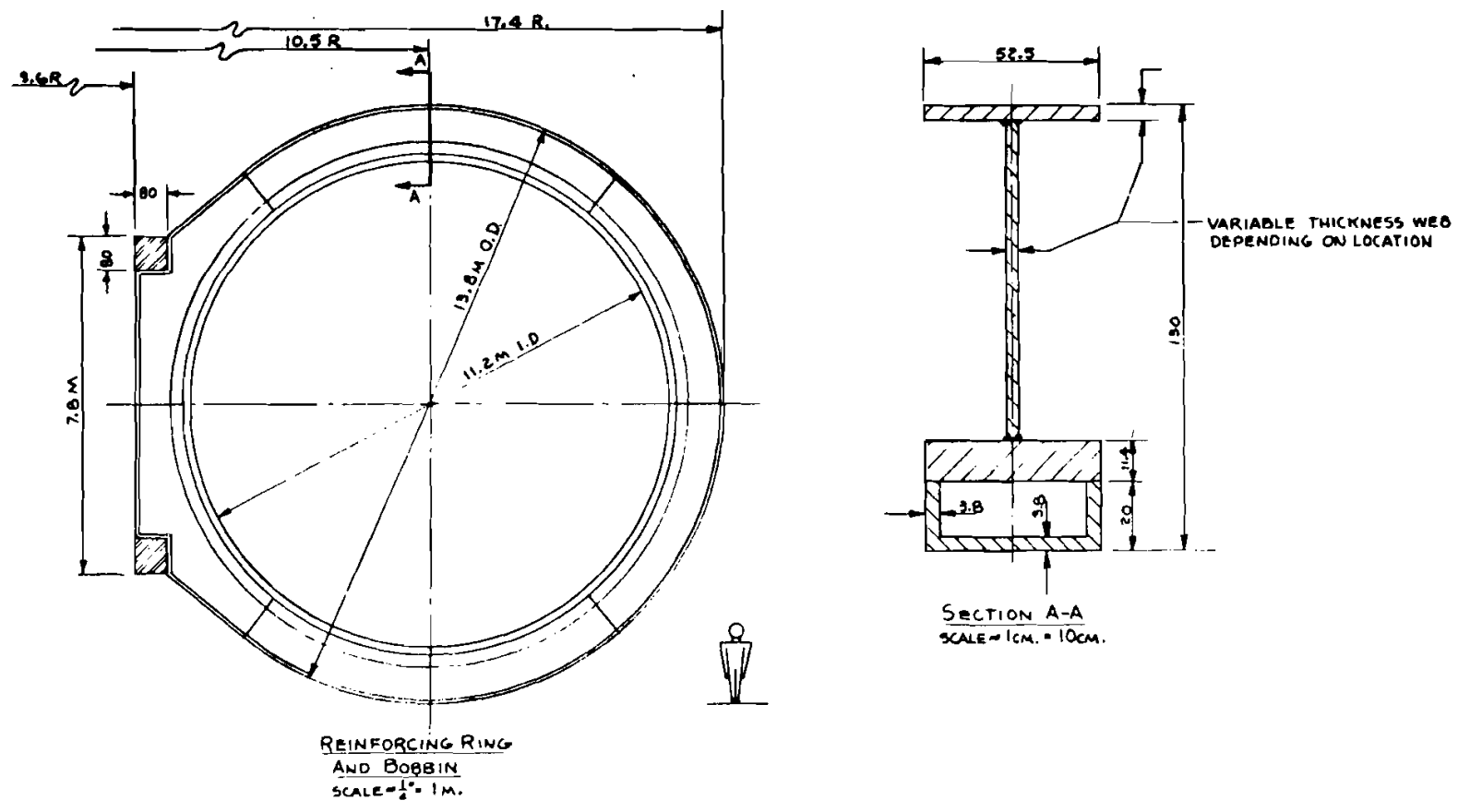

FIGURE 57 Magnet Coil Reinforcing Ring and Bobbin from the ORNL Design 
to the blanket. There will be 50 coils carrying a total current of $10 \mathrm{MA}$. The coil cross sections will be $8 \times 10 \mathrm{~cm}$, and the current density will be $3.1 \mathrm{kA} / \mathrm{cm}^{2}$. They will produce a poloidal magnetic field of $0.5 \mathrm{~T}$.

An iron magnet core is located in the "doughnut hole" of the torus to enhance the transformer action of the poloidal field coils in establishing the plasma current (Figure 56). This core is $15 \mathrm{~m}$ high by $7 \mathrm{~m}$ in diameter and weighs 210 metric tons.

Plasma Heating System for the ORNL Design - The heating effects of the 10 MA plasma current are supplemented by the injection of energetic beams of neutral fuel atoms into the plasma. About $10 \mathrm{MW}$ of neutral beam power must be supplied to the plasma during the entire 152 second duration of the thermonuclear burn. Continuous injection maintains the plasma temperatures and replaces the plasma fuel atoms which undergo fusion or escape confinement.

Neutral beam injection at an average energy of $20 \mathrm{keV}$ is assumed. However, the possibility is noted that much higher injection energies may be required to achieve adequate penetration of the beam into the plasma. This would increase the requirements for recirculated power for the injectors.

Thirty-six injector units are required. Each unit produces a beam of $20 \mathrm{~cm}$ diameter which carries an equivalent current of 14 amperes. They are assumed to be $50 \%$ efficient. The injectors are located in groups of six, in the parting planes between the six modules which comprise the toroidal reactor blanket. The ion accelerator units used to energize the beam will require considerable extrapolation of existing technology to achieve the design parameters. The neutral beam injectors are sized to deliver the entire reactor fuel throughput of $0.6 \mathrm{~kg} /$ day of tritium and $0.4 \mathrm{~kg} /$ day of deuterium.

Fuel System for the ORNL Design - Fuel must be supplied to the plasma at a rate of $0.6 \mathrm{~kg} /$ day of tritium and $0.4 \mathrm{~kg} /$ day of deuterium. It is assumed that $20 \%$ of the fue 1 undergoes fusion reactions before the thermonuclear burn is terminated--thus the actual consumption of fuel is $0.12 \mathrm{~kg} /$ day of tritium and $0.08 \mathrm{~kg} /$ day of deuterium. The fuel system separates unburned fuel from recycled plasma, purifies both recycled fuel and bred tritium recovered from the blanket, and injects the fuel into the plasma as energetic beams of neutral atoms.

About $1 \mathrm{~kg} /$ day of recycled plasma and bred tritium must be purified, along with minor amounts of other tritium-containing materials as indicated in the undefined process shown in Figure 58. (Spent plasma is supplied by the plasma chamber high vacuum pumps between burn cycles.) Cryogenic distillation is used to separate normal hydrogen $\left({ }^{1} H\right)$ from spent plasma because of formation of 1 atom of $1_{H}$ per 60 fusion reactions. About $0.16 \mathrm{~kg} /$ day of helium and $1 \mathrm{~g} /$ day of ${ }^{1} H$ must be removed. Fuel purification to $1 \%$ of ${ }^{1} \mathrm{H}$ is assumed, which is expected to be adequate for input to the plasma. The waste stream of ${ }^{1} H$ from isotope separation is assumed to be contaminated with $1 \%$ tritium. This waste is oxidized to water, reacted with calcium oxide to form $\mathrm{CaOH}$ and stored.

Neutral beams are used to inject fuel into the plasma, which contains $0.7 \mathrm{~g}$ of tritium and $0.5 \mathrm{~g}$ of deuterium. The injectors used to heat the plasma to ignition conditions are used for fuel injection. 


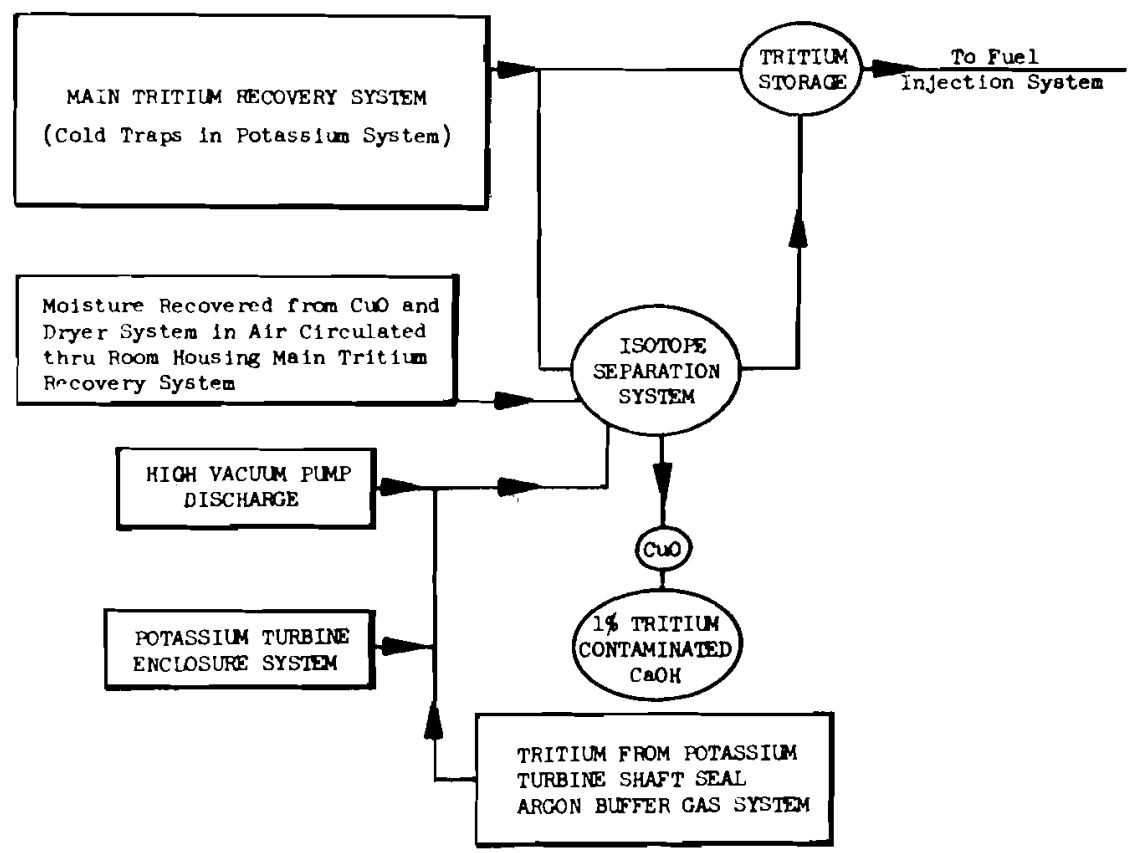

FIGURE 58 Fuel Purification Process for the ORNL Design

Blanket for the ORNL Tokamak - Liquid lithium metal is the fertile material for tritium breeding and the blanket coolant. Graphite moderator is also included. These choices are based upon low cost, excellent breeding characteristics, system simplicity and reliability. Niobium alloy ( $\mathrm{Nb}-1 \% \mathrm{Zr}$ ) is the structural material, primarily because of its compatibility with liquid lithium at high temperatures. This choice is based upon achievement of high temperature operation, to maximize efficiency and minimize thermal pollution.

The blanket is located inside the toroidal field coils adjacent to the plasma (Figure 56). It is continuous, since no divertor is used. The blanket is $100 \mathrm{~cm}$ thick, and is followed by an $88 \mathrm{~cm}$ thick shield to protect the superconducting magnets from particles, radiation and heat escaping from the blanket. Thermal insulation is provided between the blanket, shield and the superconducting toroidal field coils by evacuated spaces separating these regions (Figure 59). The nonsuperconducting poloidal field coils are located within the shield tank, along the inner surface adjacent to the blanket.

The blanket is composed of 60 channels, one of which is shown in the cross section in Figure 60 . The inner wall facing the evacuated plasma region is curved, and is stressed in tension. Each of the lithium regions is $30 \mathrm{~cm}$ thick, and the graphite region is $39 \mathrm{~cm}$ thick.

Each of the channels, called racetracks, is located along a segment of a circle about the major axis of the torus (Figure 56). Liquid lithium coolant flows through these channels following the lines of the toroidal magnetic field. The torus is made up of six $60^{\circ}$ sectors, and at the parting planes the lithium flowing along the vacuum wall is ducted outward, past the graphite, into the outer lithium region where the flow is in the reverse direction. Upon reaching a parting plane the flow in the outer region is ducted inward, back to the region of the vacuum wall in continuous circulation and hence the term racetracks (Figure 61). 


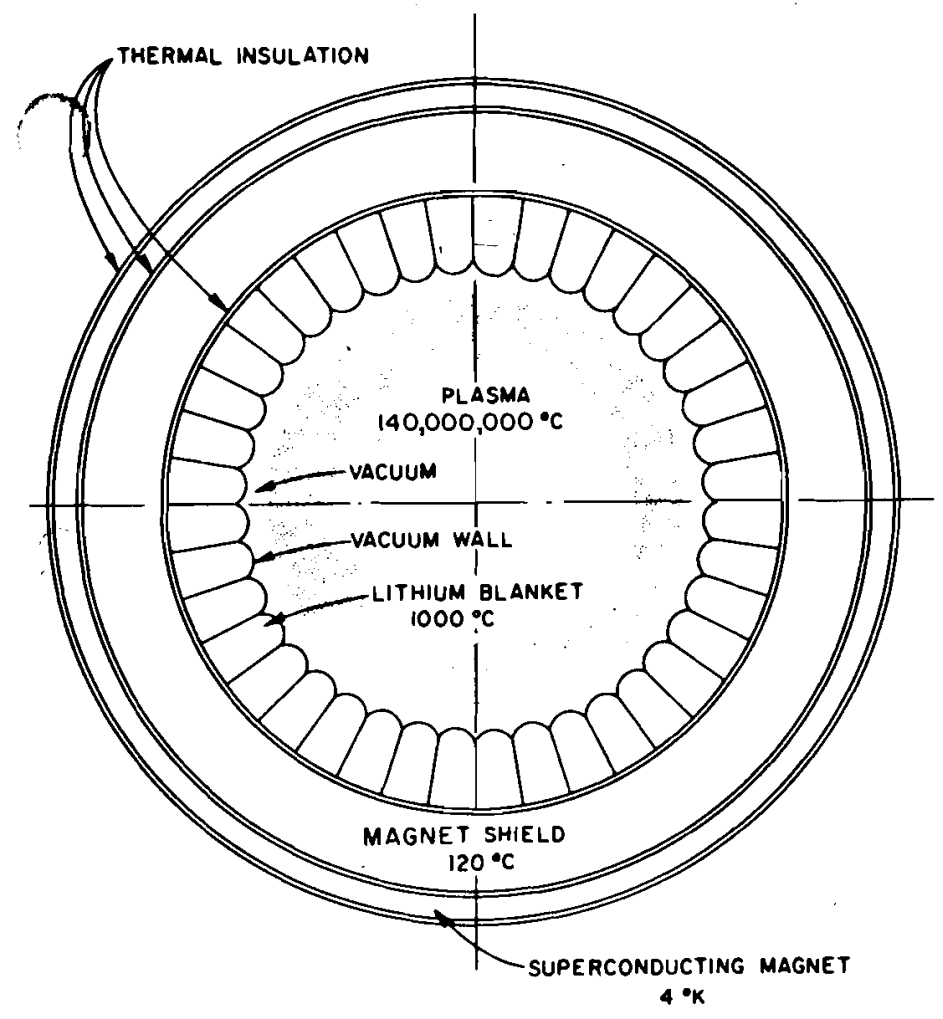

FIGURE 59 Section Through the Minor Diameter of the ORNL Design

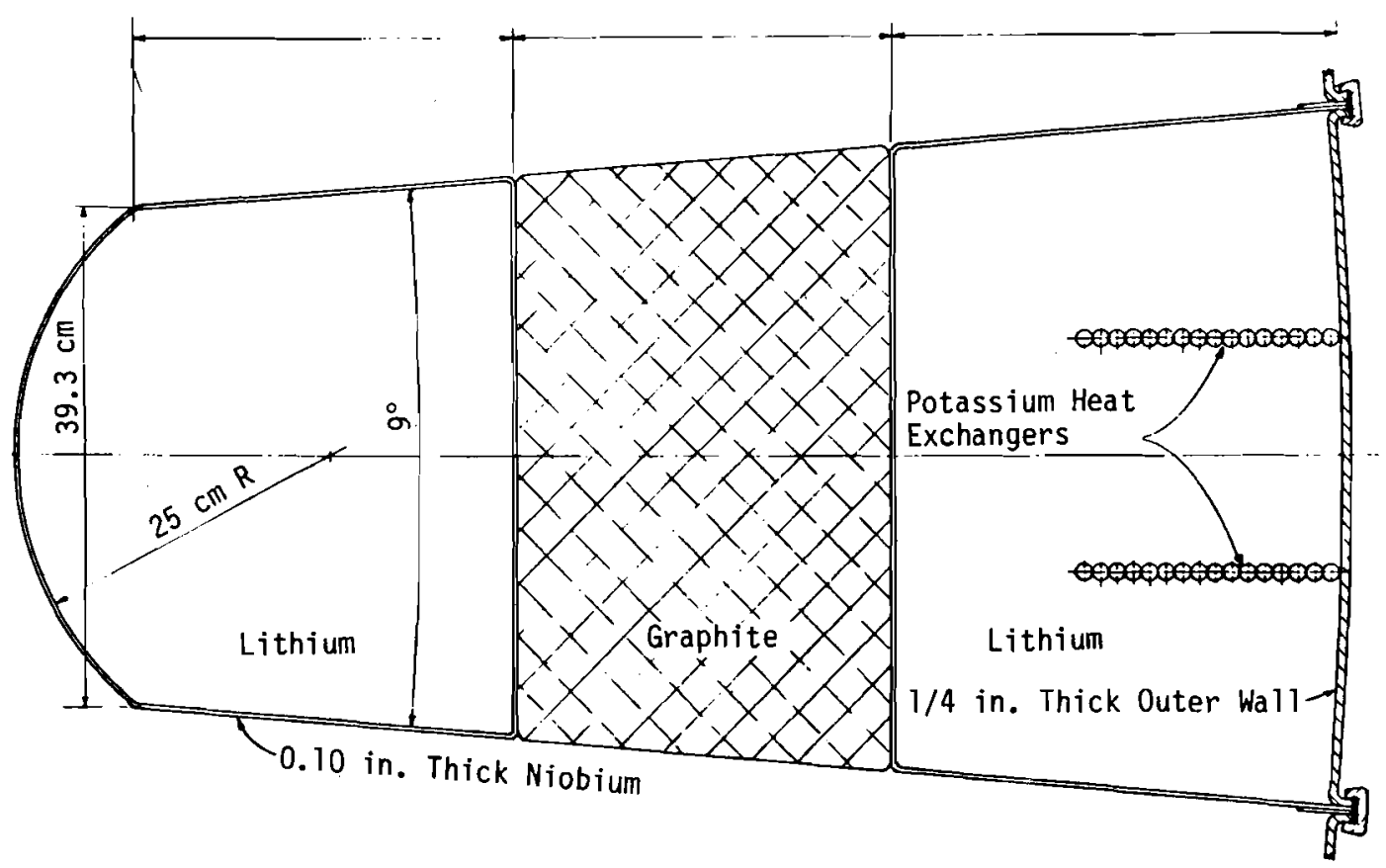

FIGURE 60 Vertical Cross Section Through the Racetrack in the ORNL Design 


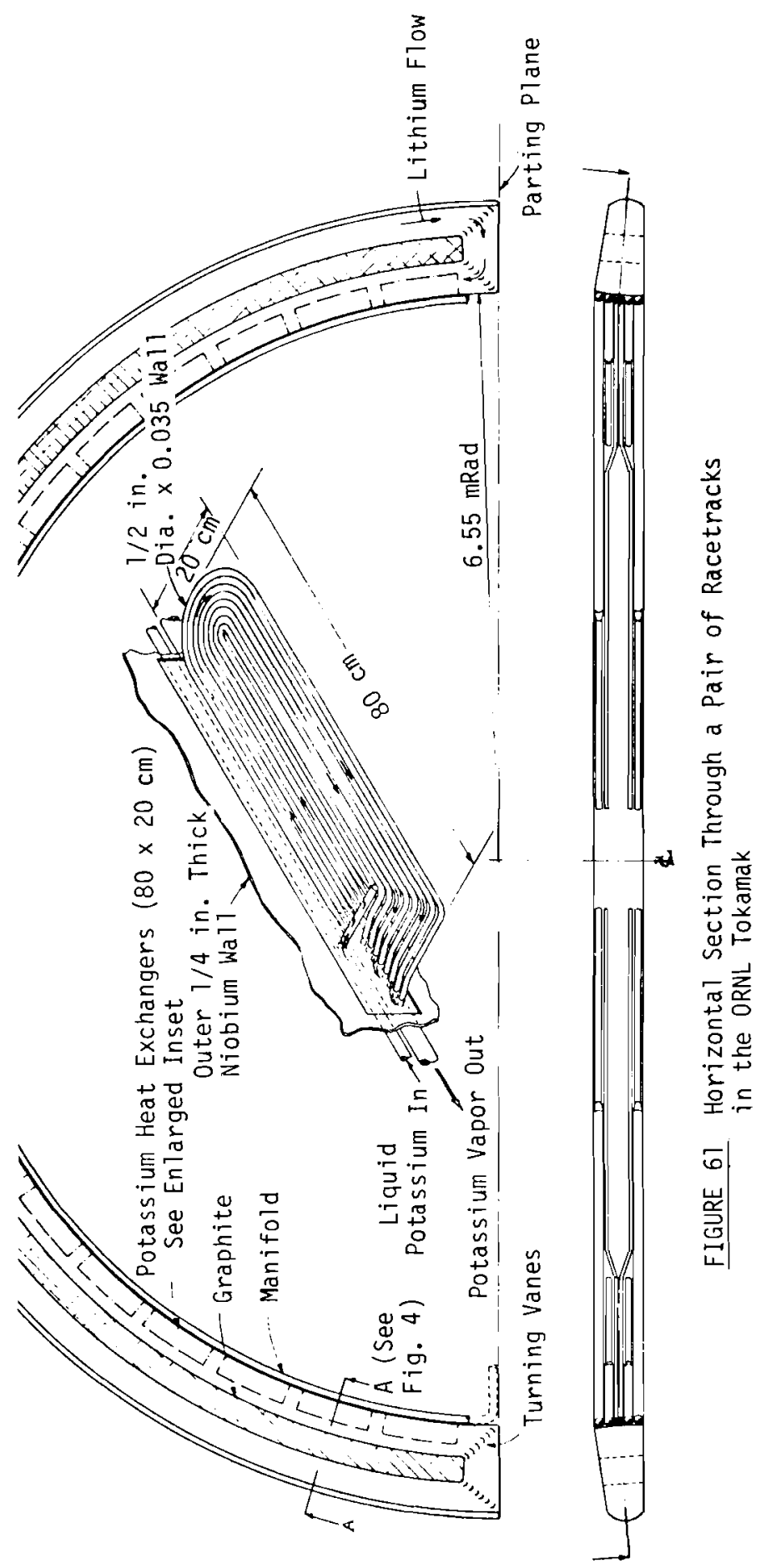


The liquid lithium primary coolant does not leave the channels. Heat deposited in the blanket is removed by heat exchange to small boiler tubes in the outer flow region. The extraction of tritium bred in the 1 ithium is also accomplished within the blanket. The tritium simply permeates through the niobium heat exchanger tubes into the potassium intermediate coolant.

The blanket is followed by a magnet shield composed of $65 \mathrm{~cm}$ of graphite and $21 \mathrm{~cm}$ of 1 ead, to stop neutrons and gamma rays respectively. This shield is enclosed in a titanium shell $1 \mathrm{~cm}$ thick, and is cooled by helium gas at a pressure of 10 atmospheres. Positions and thicknesses of blanket and shield components, and their relation to the magnet coils, are indicated in Table 13.

TABLE 13 Position and Thickness of the ORNL Blanket and Shield Components

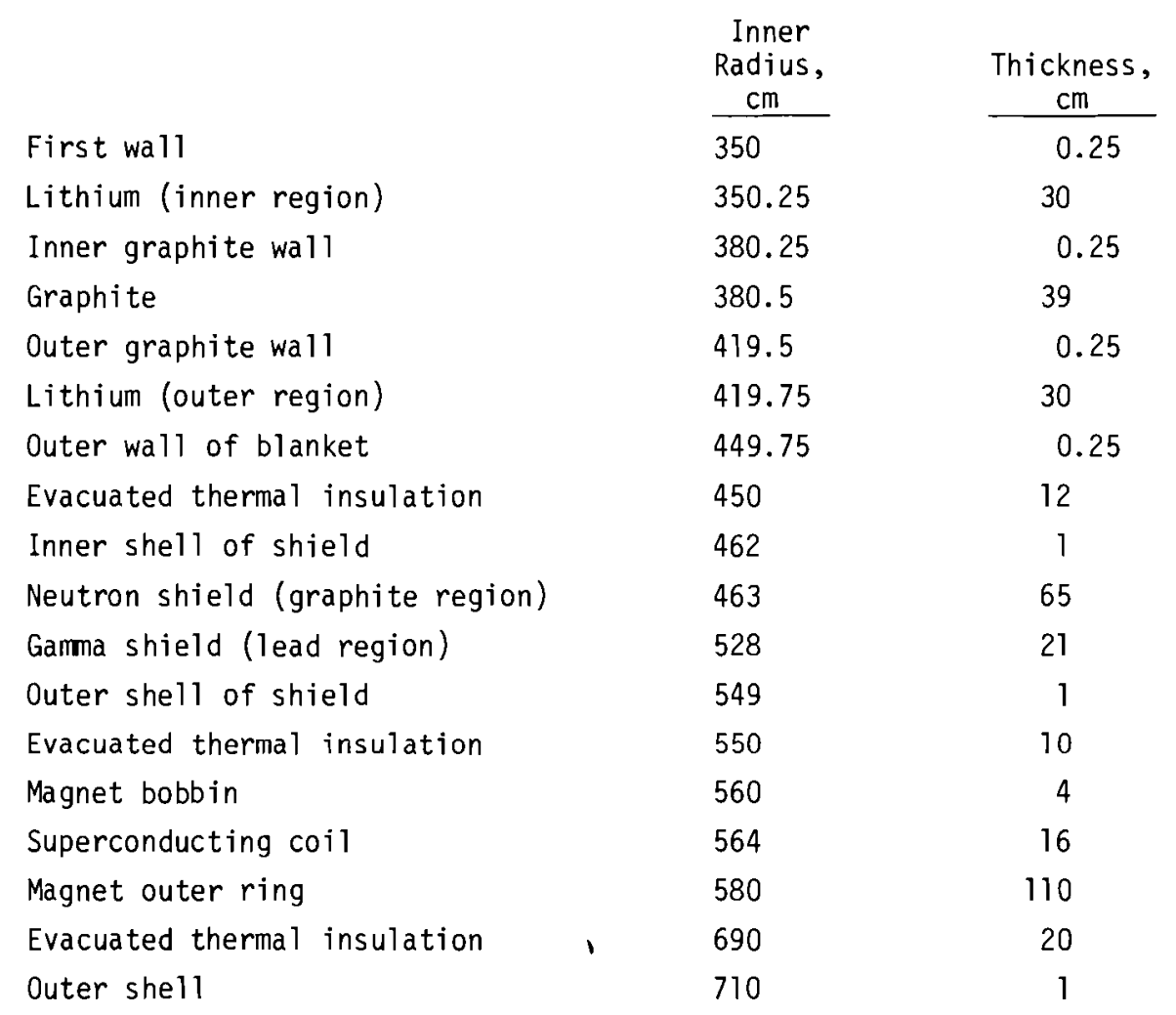

Each of the six $60^{\circ}$ modules which make up the complete torus contains 23 metric tons of niobium, 183 metric tons of graphite and 77 metric tons of lithium in the blanket region. The shield region of each module contains 500 metric tons of graphite, 300 metric tons of 1 ead and 17 metric tons of titanium.

Radiation damage is expected to limit the life of the niobium first wall. At the first wall neutron energy loading of $0.43 \mathrm{MW} / \mathrm{m}^{2}$ it is likely that the blanket segments will have to be replaced after 10 years in the reactor. If $1 / 10$ of the blanket is replaced annually, this will yield 14 metric tons per year of niobium structure and 110 metric tons per year of graphite. Tht: 
activity of the structure will be $7 \times 10^{7} \mathrm{Ci}$, producing $0.25 \mathrm{MW}$ of afterheat 1 minute after shut-

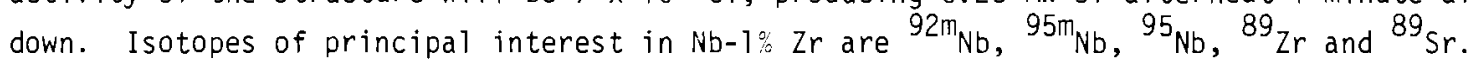

The lithium and potassium cleanup systems have not been designed.

Heat Transfer System for the ORNL. Design - Liquid lithium is the primary coolant carrying the heat to heat exchangers located in the outer regions of the blanket. The heat is transferred to boiling potassium intermediate coolant, producing vapor to drive a topping-cycle turbinegenerator. The condenser for the topping turbine is a steam generator which is used to raise steam to drive conventional turbine-generators (Figure 62).

The design requires $4.6 \times 10^{5} \mathrm{~kg}$ of natural lithium primary coolant, which is circulated with a total mass flow rate of $3.2 \times 10^{7} \mathrm{~kg} / \mathrm{hr}$. Lithium is to be supplied within the individual "racetrack" blanket segments to the first wall region of the racetracks at $996^{\circ} \mathrm{C}$, and exits to the outer region at $1052^{\circ} \mathrm{C}$.

The lithium is pumped electromagnetically by passing a direct current across the radial-flow passages at the racetrack ends (Figure 63). The current is actually directed around the entire blanket periphery. (The racetracks are insulated with $\mathrm{Al}_{2} \mathrm{O}_{3}$ except where the current passes.) It is estimated that a pressure differential of only $0.07 \mathrm{~kg} / \mathrm{cm}(1 \mathrm{psi})$ is sufficient to pump the lithium coolant. The lithium pressure is about $0.1 \mathrm{~kg} / \mathrm{cm}(0.1$ atmosphere $)$.

Heat is exchanged from the lithium primary coolant to potassium intermediate coolant in niobiumtube-bank boilers located in the racetrack outer flow regions (Figures 60 and 61 ). The tube banks are made from 10 tubes each of $1.3 \mathrm{~cm}$ outside diameter, with a wall thickness of $0.15 \mathrm{~cm}$. Each racetrack has between 14 and 28 tube banks depending on its length. The total heat exchange area of the tube banks is $1.8 \times 10^{3} \mathrm{~m}^{2}$.

Liquid potassium enters the tube banks at a temperature of $927^{\circ} \mathrm{C}$ and a pressure of $8.4 \mathrm{~kg} / \mathrm{cm}^{2}$; potassium vapor exits at $982^{\circ} \mathrm{C}$ and $5.8 \mathrm{~kg} / \mathrm{cm}^{2}$. The total potassium mass flow rate is $1.8 \times 10^{6}$ $\mathrm{kg} / \mathrm{hr}$, and the coolant mass is $1.0 \times 10^{4} \mathrm{~kg}$.

The potassium vapor drives the topping turbine, and exits at a temperature of $593^{\circ} \mathrm{C}$. It is condensed in the steam generator at a pressure of $0.17 \mathrm{~kg} / \mathrm{cm}^{2}$, and exits at $587^{\circ} \mathrm{C}$. The potassium condensate is pumped to a feed heater where it is heated to $927^{\circ} \mathrm{C}$ for return to the blanket. The feed pump is driven by a potassium turbine fed by vapor extracted from the topping turbinegenerator. Extracted potassium vapor is also used to heat the potassium condensate in the feed heaters.

About $20 \%$ of the potassium condensate flow $\left(3.6 \times 10^{5} \mathrm{~kg} / \mathrm{hr}\right)$ is diverted to a cold trapping system for the removal of tritium. This flow is passed through a regenerative heat exchanger to conserve energy, and is returned to the feed heaters at $555^{\circ} \mathrm{C}$.

The potassium condenser/steam generator utilizes a shell-and-tube design with a surface area of $3000 \mathrm{~m}^{2}$. This includes two sections of steam reheat. Potassium vapor is on the shell side, and water/steam on the tube side. A reentrant-tube design is specified (Figure 64). The feed water will boil in the inner tube so that only steam will be present in the outer tube which interfaces 


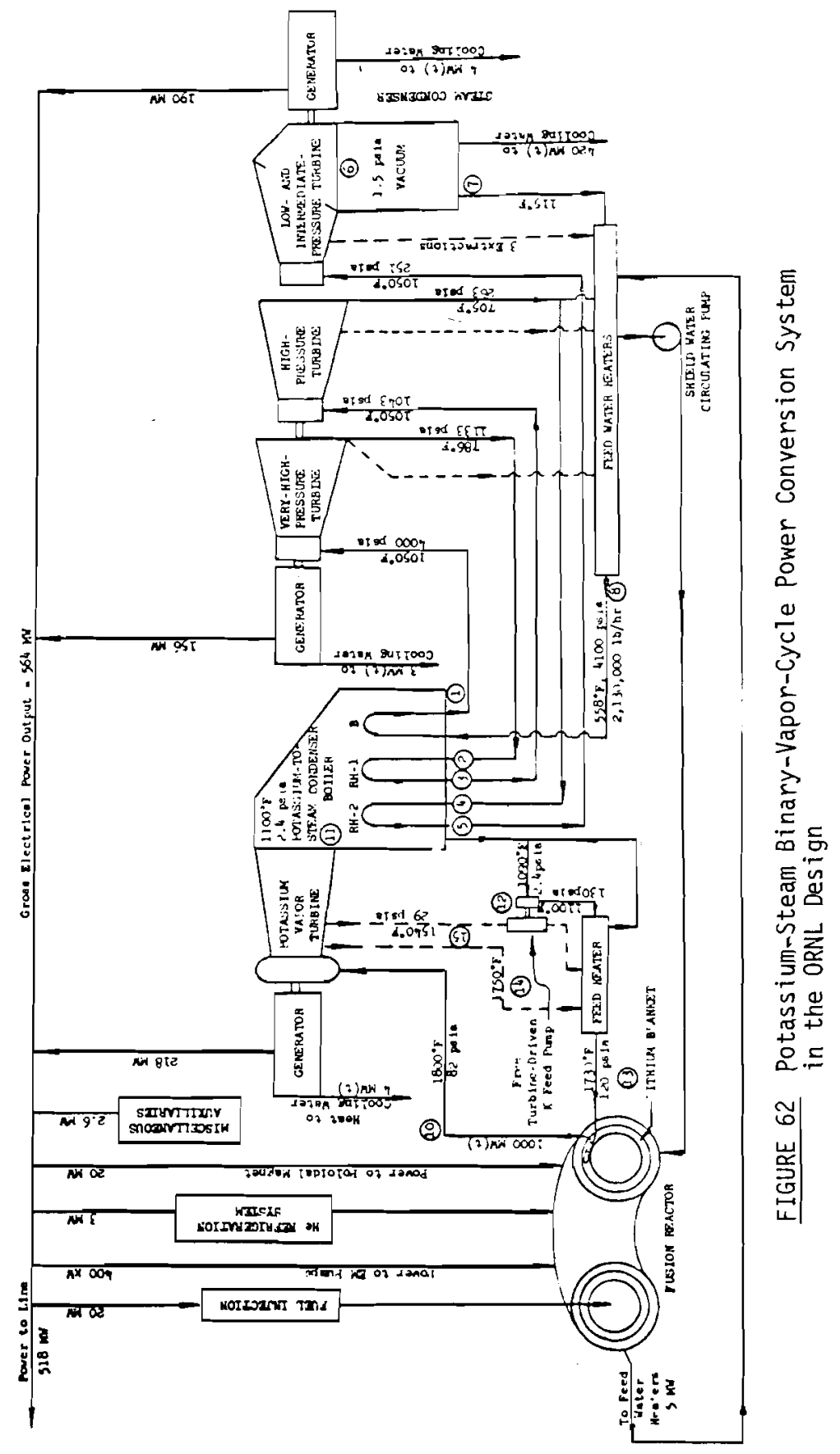




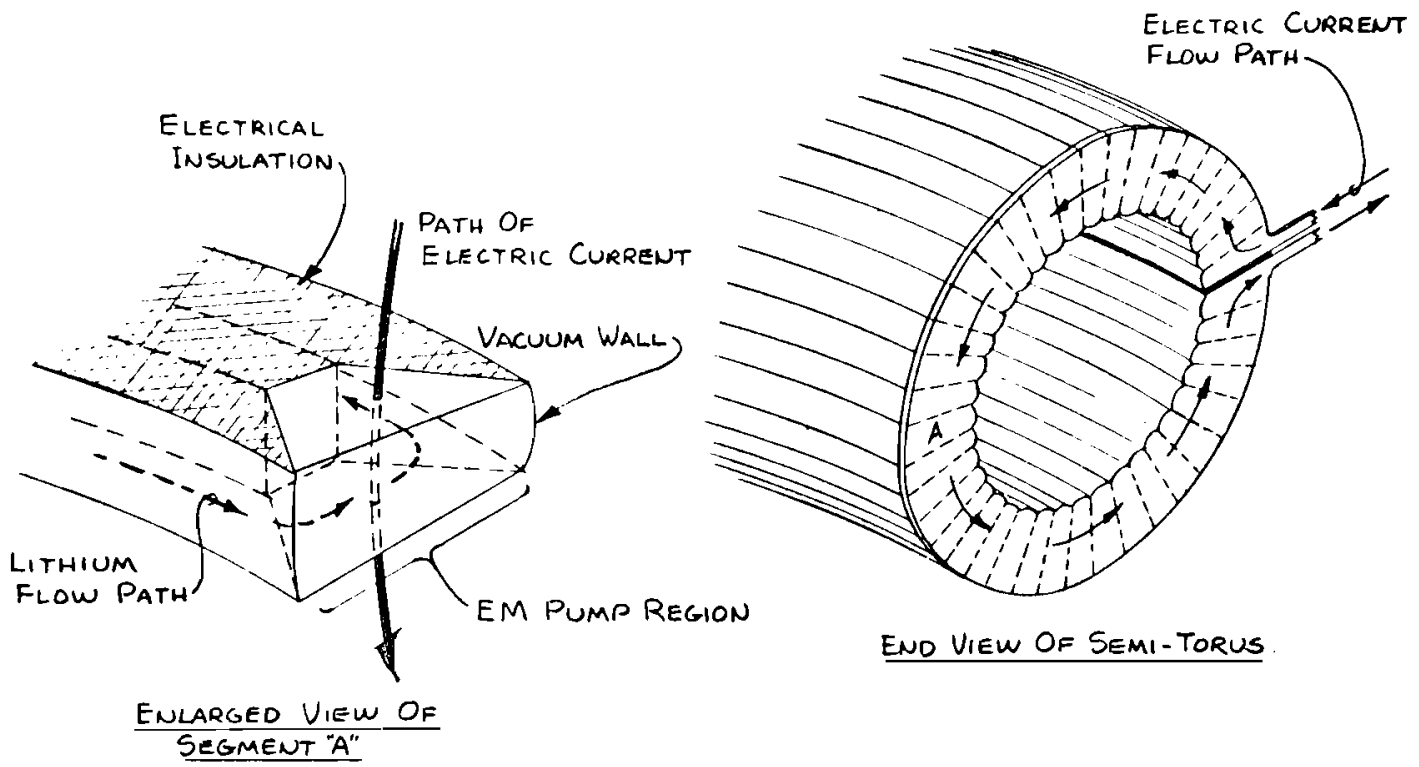

FIGURE 63 Blanket Lithium Circulation System in the ORNL Tokamak

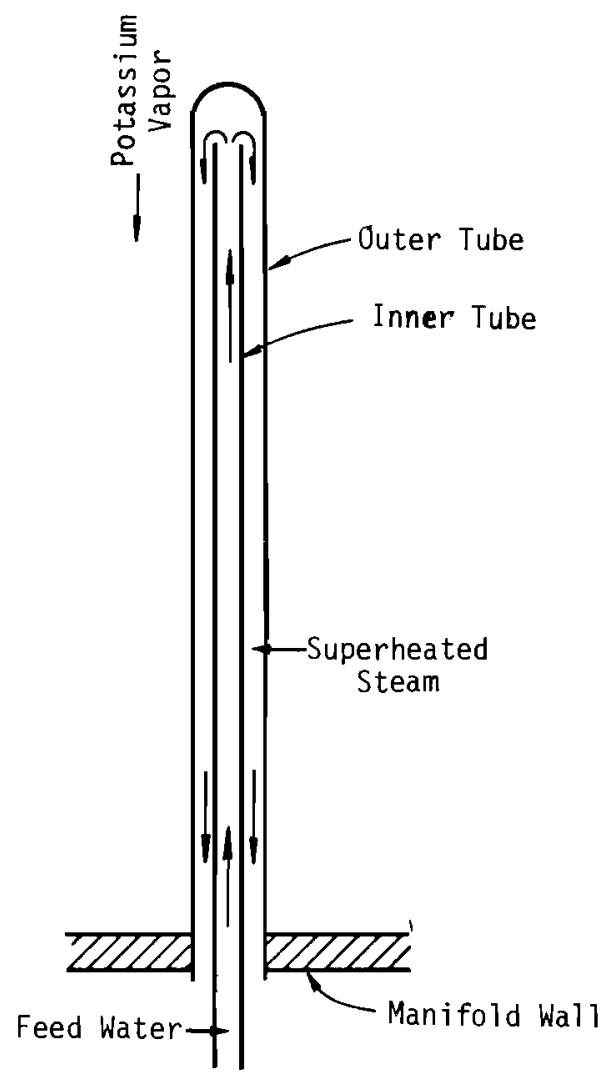

FIGURE 64 Section Through a Reentry Tube for the Potassium Condenser-Steam Boiler of the ORNL Tokamak 
with the potassium. In the event of a tube leak, the chemical reaction between steam and liquid metal is less violent than when liquid water is present; consequently, the potential for progressive failures of successive tubes, and other attendant steam generator damage, is reduced. The tubes will be of $2 \mathrm{~mm}$ thick niobium, with a tungsten coating $0.3 \mathrm{~mm}$ thick on the outer tube to inhibit the permeation of tritium into the steam.

Water enters the steam generator at a temperature of $316^{\circ} \mathrm{C}$ and a pressure of $289 \mathrm{~kg} / \mathrm{cm}^{2}$; it exits as steam at $566^{\circ} \mathrm{C}$ and $282 \mathrm{~kg} / \mathrm{cm}^{2}$. The mass flow rate of steam is $1.5 \times 10^{6} \mathrm{~kg} / \mathrm{hr}$. Each of the reheats returns the steam to $566^{\circ} \mathrm{C}$, at outlet pressures of $73.4 \mathrm{~kg} / \mathrm{cm}^{2}$ and $17.7 \mathrm{~kg} / \mathrm{cm}^{2}$.

Electricity Generation System for the ORNL Design - Electricity is generated by a topping-cycle turbine-generator driven by potassium vapor intermediate coolant, and by a cross compound steam turbine arrangement which drives two generators (Figure 62).

Superheated steam flows from the potassium-condenser/steam boiler at a rate of $1.5 \times 10^{6} \mathrm{~kg} / \mathrm{hr}$. It is used to drive a very high pressure (VHP) turbine, reheated (RH-1) in the condenser/boiler, and then used to drive a high pressure (HP) turbine on the same (high pressure) generator shaft. The steam is again reheated ( $\mathrm{RH}-2)$ in the condenser/boiler and used to drive a combination low and intermediate pressure turbine on a second (low pressure) generator shaft. Steam is extracted from the VHP and HP turbines for heating feedwater for the condenser/boiler. Flow parameters are indicated on Figure 62.

The steam which passes through the turbines is condensed at a pressure of 1.5 psia and a temperature of $27^{\circ} \mathrm{C}$.

The gross electrical output of the generators is 564 MWe. Of this 218 MWe is produced in the potassium turbine-generator. The steam system generators on the high and low pressure shafts produce 156 and 190 MWe, respectively. About $8 \%$ of the gross output (46 MWe) is used to operate auxiliary plant equipment. Major uses are as follows: poloidal magnet (nonsuperconducting), $20 \mathrm{MW}$; fuel injection, $20 \mathrm{MW}$; cryogenic refrigeration, $3 \mathrm{MW}$; electromagnetic pumps (1ithium coolant), $0.4 \mathrm{MW}$; miscellaneous, $2.6 \mathrm{MW}$. The net plant output is 518 MWe, produced from 1000 MWt. The gross thermal efficiency of generation is $56 \%$, and the net plant efficiency is $52 \%$ (these high values are, of course, due to the high coolant temperatures and use of the potassium topping cycle). The net plant heat rate is $6589 \mathrm{Btu} / \mathrm{kWh}$. The waste heat dissipation system has not been designed.

Spent PIasma Collection System for the ORNL Design - Partially burned fuel from the plasma will be scavenged between thermonuclear burn cycles by vacuum pumping. No divertor is included to collect plasma escaping confinement during the burn. Consequently, the plasma chamber vacuum system collects about $0.5 \mathrm{~kg} /$ day of tritium, $0.3 \mathrm{~kg} /$ day of deuterium, and $0.16 \mathrm{~kg} / \mathrm{day}$ of helium.

Following termination of a burn plasma, ions cool and combine with electrons, forming neutral gas atoms. The neutralized plasma, no longer subject to magnetic confinement, expands to fill the plasma chamber; it enters the gaps between blanket sextants and the ductwork of the vacuum system, cooling further in the blowdown process. Following blrwlci.. une torus pri:sure is 
$9 \times 10^{-3}$ torr. It is reduced to $1.1 \times 10^{-3}$ torr in 15 seconds by turbo-molecular vacuum pumps having a pumping speed of 50,000 liters/second. The turbo-molecular vacuum pumps and their forepumps have not been designed.

The plasma chamber vacuum system is designed to draw a vacuum of $10^{-6}$ torr at initial reactor startup, to protect the hot niobium structure from corrosion. After startup, when the interior atmosphere consists only of hydrogen and helium, this is no longer necessary and a pressure of $10^{-3}$ torr is maintained.

Bred Tritium Recovery System for the ORNL Tokamak - The breeding ratio of tritium in the blanket lithium is between 1.3 and 1.4 , resulting in the breeding of about $0.16 \mathrm{~kg} /$ day of tritium. The design calls for this tritium to permeate into the potassium intermediate coolant through the niobium heat exchanger tubes in the blanket. It is then "gettered" by a small amount of lithium dissolved in the potassium condensate tank. From this tank a sidestream is sent through cold traps where lithium tritide is condensed and filtered out. Two cold traps are operated alternately, with one trapping and the other regenerating. Regeneration is accomplished by heating to decompose the LiT, pumping the liberated tritium through a permeable "window" to storage, and returning the lithium to the condensate tank (Figure 65).

Additional study, since publication of the design document, has yielded the result that the required cold traps would be unacceptably large. (13) A different method has therefore been proposed to recover tritium from lithium in the blanket. The annular region between the blanket and shield would be maintained at a vacuum of $10^{-5}$ torr, and the tritium would permeate through the niobium walls of the blanket, for recovery by the vacuum system.

The tritium inventory of the plant is estimated to be about $6 \mathrm{~kg}$ with the distribution shown in Table 14. Tritium flows in the plant are indicated in Figure 66.

Containment Building for the ORNL Concept - The reactor is contained within a stainless steel lined concrete cell which operates at a pressure of $10^{-3}$ torr. Evacuation of the cell reduces air leakage into the reactor, prevents oxidation of hot niobium piping and structure, allows recovery of tritium leaking from the reactor, and prevents oxidation (fires) of the 1 ithium metal primary coolant in the event of leaks. (The lithium circulates only within the reactor blanket and is not piped outside of the cell.) The containment building, including this cell, is shown in Figure 54 .

Equipment for recovering tritium from the liquid potassium intermediate coolant, and for tritium storage, is located beneath the floor of the reactor cell, within the containment building. This region is also stainless steel lined to allow hermetic sealing but it is not evacuated. Ventilation air from this region is monitored and, if necessary, treated to recover leaked tritium by oxidation and drying.

The reactor cell is $60 \mathrm{~m}$ in diameter and $25 \mathrm{~m}$ high. Its walls are about $1.2 \mathrm{~m}$ thick, to provide radiation shielding. Access to the cell is provided by a personnel airlock and an equipment access door having diameters of $2.1 \mathrm{~m}$ and $15 \mathrm{~m}$, respectively. 


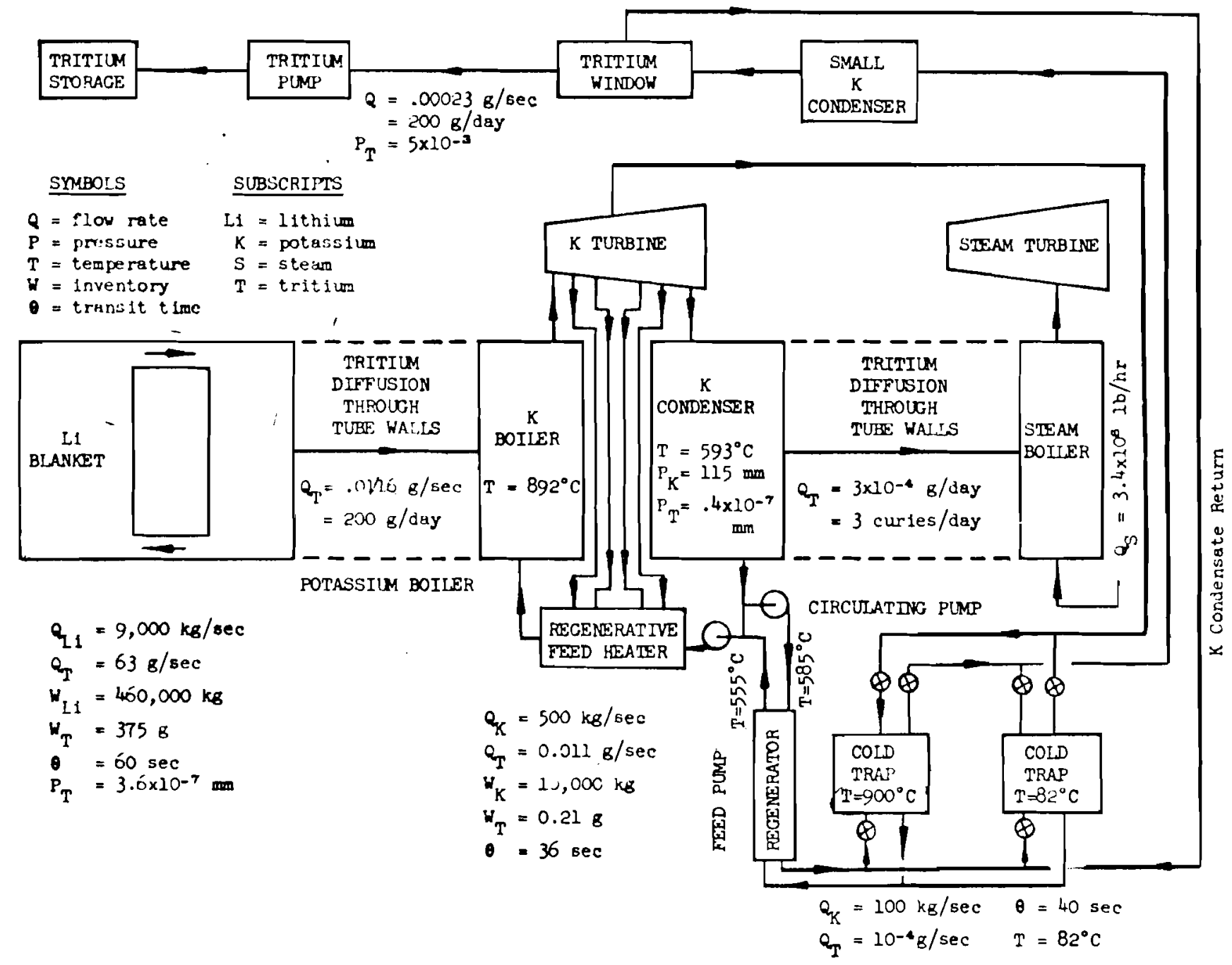

FIGURE 65 Cold Trap System for Removing Tritium from the ORNL Tokamak

TABLE 14 ORNL Power Plant Tritium Inventory (a)

\begin{tabular}{lr} 
Lithium Primary Coolant & $\begin{array}{r}\text { Tritium } \\
\text { (grams) }\end{array}$ \\
Niobium Structure & 120 \\
Plant Active Inventory & 21 \\
$\quad$ Storage & 141 \\
Total Plant Tritium Inventory & $\underline{5600}$ \\
\hline
\end{tabular}

a. The tritium stored is 47 times the daily consumption rate, and 9.3 times the daily injection rate. 


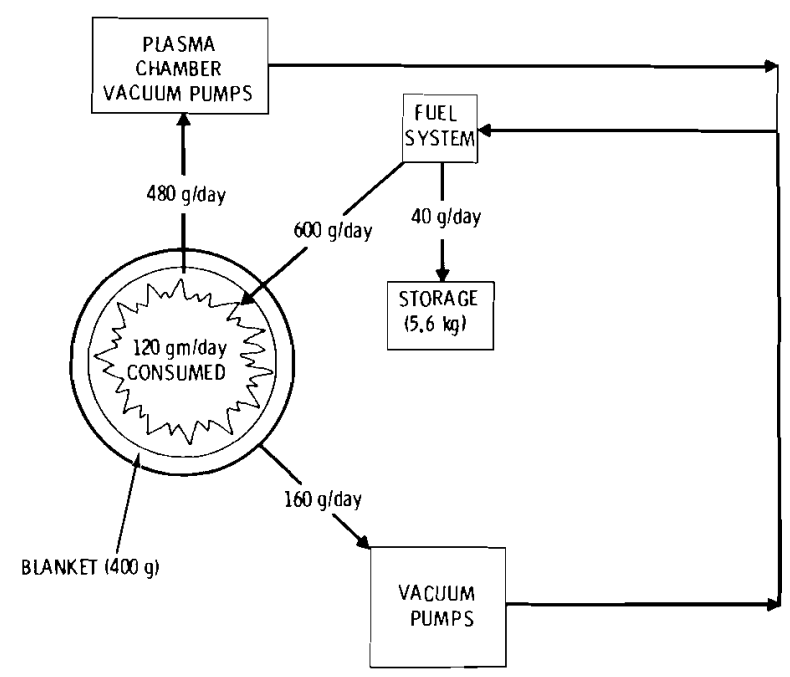

FIGURE 66 Tritium Flow and Inventory for the ORNL Reactor Concept

\subsection{Theta Pinch Magnetic Confinement}

In a theta pinch device, a fast-rising magnetic field is used to heat and compress plasma to thermonuclear ignition conditions. The applied magnetic field induces currents in the plasma by transformer action, which flow in the "theta" direction encircling the coil axis. Interaction of these currents with the rising magnetic field heats and compresses the plasma--hence, the "theta pinch." Theta pinch reactors inherently operate in short pulses.

\subsubsection{Los Alamos Theta Pinch}

Summary Description - The LASL theta pinch power plant ${ }^{(8)}$ produces 4132 MWe of net electrical power on a continuous basis from an average thermal energy release of 12,000 MWt. The thermonuclear burn cycle of this reactor is 3 seconds long, most of which is required for reactor purging and refueling. The burn duration is $70 \mathrm{mill}$ iseconds. Energy deposited in the blanket during the brief burn pulse is removed between pulses, allowing continuous electrical generation. Overall power plant layout is shown in Figure 67.

The reactor is cooled by molten lithium metal, which also functions as a neutron moderator and a fertile material to breed tritium fuel. This primary coolant transfers heat to a low-radioactive sodium intermediate coolant that transports it to steam generators. Steam, at $484^{\circ} \mathrm{C}$ and $171 \mathrm{~kg} / \mathrm{cm}^{2}$, is used to drive the turbine generators.

Major power plant systems are identified and their functional relations are indicated in Figure 68. The reactor is provided with two levels of containment. Primary containment is provided by an evacuated cell immediately enclosing the reactor. Secondary containment is provided by a buffer region within the reactor building, surrounding the primary containment. This region contains primary coolant piping and tritium handling equipment. It is purged with helium to collect tritium leakage and to prevent liquid metal fires. 


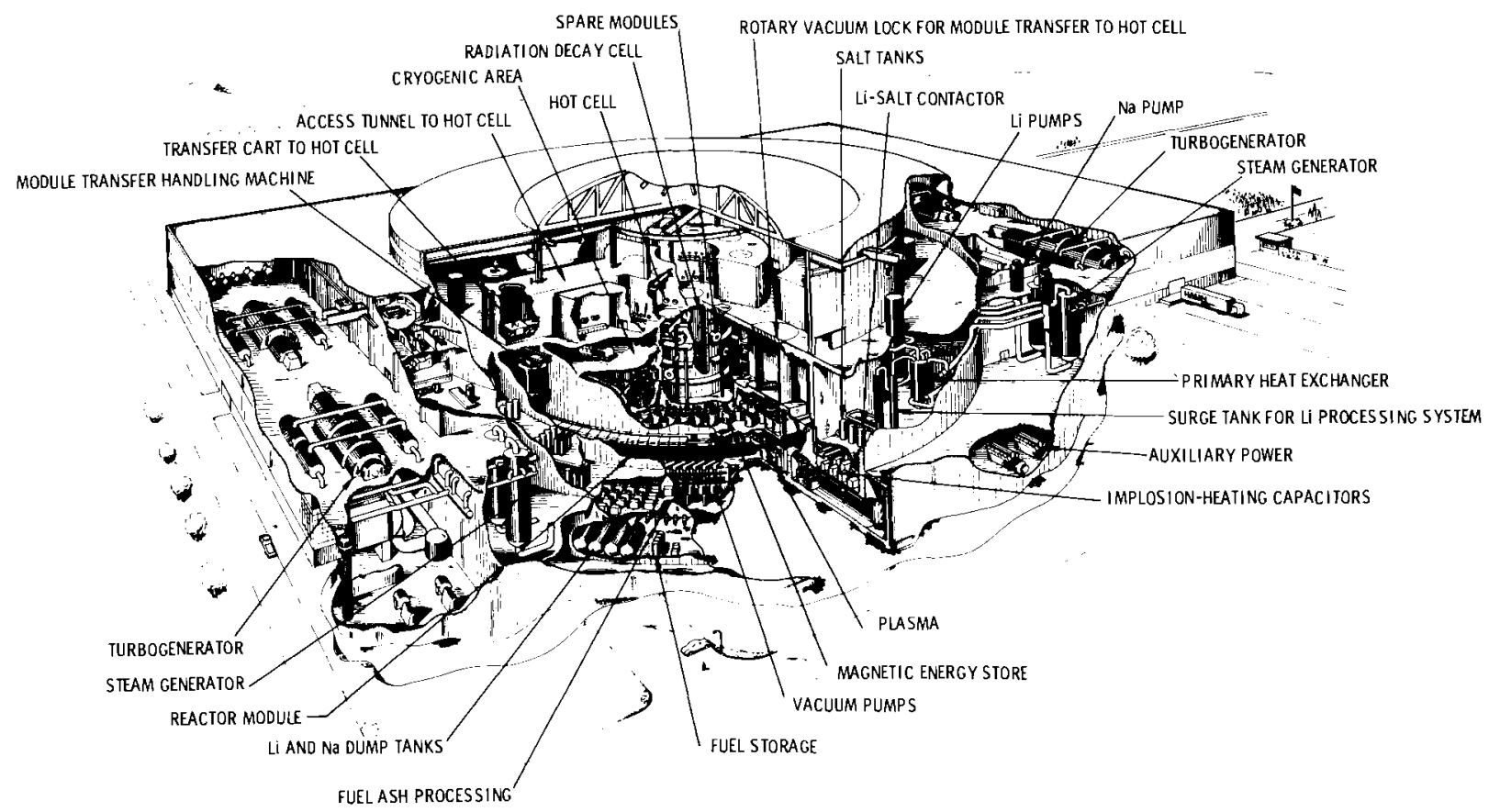

FIGURE 67 The LASL Theta Pinch Power Plant

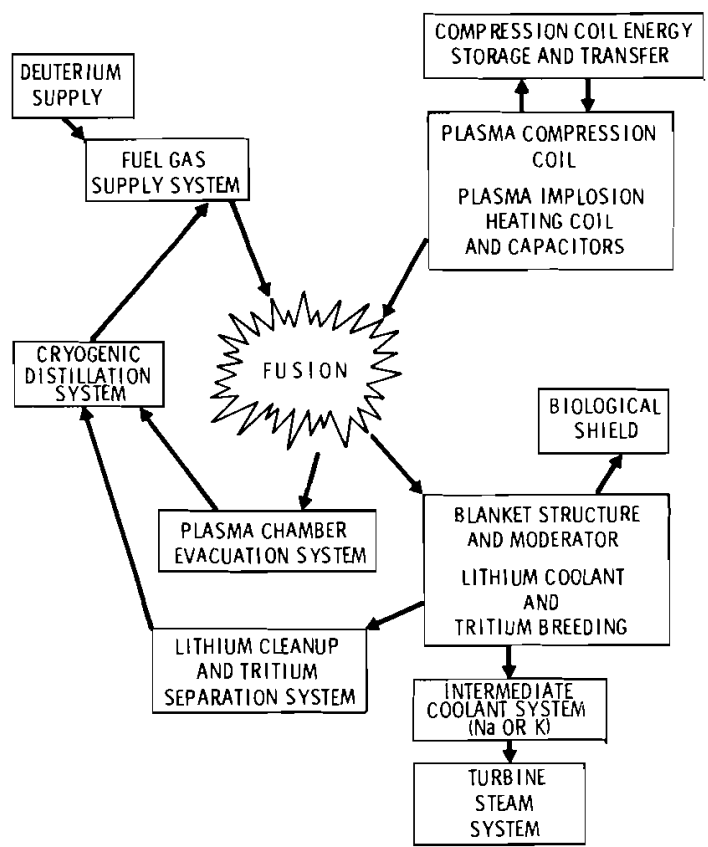

FIGURE 68 Functional Relations Between Systems of the LASL Theta Pinch Power Plant 
The diameter of the reactor is $115 \mathrm{~m}$. The major and minor radi $i$ of its toroidal plasma chamber are $56 \mathrm{~m}$ and $0.5 \mathrm{~m}$. It is constructed primarily of niobium structural material.

Plasma confinement and compression is primarily achieved by 704 nonsuperconducting magnet coils called compression coils. These coils produce a toroidal field in the plasma chamber of $11 \mathrm{~T}$.

Initial confinement and heating of the plasma is accomplished by nonsuperconducting magnetic implosion coils that establish a $1.4 \mathrm{~T}$ field within 0.1 microsecond and heat the plasma to a kinetic temperature of $2.3 \mathrm{keV}$. The implosion heating field is then added to the slower rising magnetic compression field which further heats the plasma to ignition at an ion temperature of $6.1 \mathrm{keV}$. The plasma contains equal numbers of deuterium and tritium atoms. The plasma chamber fue 1 charge is $0.9 \mathrm{~g}$ of tritium and $0.6 \mathrm{~g}$ of deuterium.

Fuel gas present in the plasma chamber prior to implosion heating forms the plasma and fuels the thermonuclear burn; no fuel is injected into the plasma during the burn. The amount of fuel in the chamber at the start of the burn period is $30.4 \mathrm{~kg} /$ day of tritium and $20.2 \mathrm{~kg} /$ day of deuterium. Of this, $5 \%$ is burned, yielding a fuel consumption rate of $1.5 \mathrm{~kg} /$ day of tritium and $1.0 \mathrm{~kg} /$ day of deuterium. Additional fuel gas is introduced into the plasma chamber during and after termination of the burn. Total fuel gas flow is $240 \mathrm{~kg} /$ day, of which $144 \mathrm{~kg} / \mathrm{day}$ is tritium. Unburned fuel is purified by cryogenic distillation and recycled.

Energy collection and tritium breeding take place in a $38 \mathrm{~cm}$ thick blanket located between the plasma and the nonsuperconducting magnet coils. The reactor is composed of 176 self-contained independent modules. Blanket regions are indicated in Figure 69.

The blanket is constructed of $\mathrm{Nb}-1 \% \mathrm{Zr}$. This structure, including the plasma chamber first wall, is electrically insulated with alumina $\left(\mathrm{Al}_{2} \mathrm{O}_{3}\right)$. The blanket structural material contains beryllium for neutron multiplication and a graphite neutron moderator. In addition to the natural lithium coolant, it also contains a layer of lithium highly enriched in ${ }^{6}$ i, to enhance tritium breeding. Behind the first wall, the blanket consists of alternating lithium coolant ducts and solid blanket layers up to several centimeters thick. Material layers other than coolant are: beryllium, two layers of graphite, and ${ }^{6} \mathrm{Li}$. Solid blanket materials are canned in niobium and insulated with a layer of alumina.

Radiation damage requires replacement of blanket modules after 5 years in the reactor. This results in an average rate of solid waste production of 233 metric tons per year. In addition, several liters/year of corrosion products are produced by coolant cleanup.

Eight independent 1 ithium/sodium/steam coolant loops remove heat from the blanket. Hot leg temperatures are $547^{\circ} \mathrm{C}, 522^{\circ} \mathrm{C}$ and $484^{\circ} \mathrm{C}$. Although this power cycle does not fully utilize the high temperature properties of the niobium structural materials, it is within the state-of-the-art. Liquid metal pumps, heat exchangers, and steam generators use LMFBR technology.

Electricity is generated by four tandem-compound turbine-generators at a thermal efficiency of $42 \%$. Net plant efficiency is $34 \%$. Direct conversion of plasma energy into electrical energy takes place within the circuits which transfer electrical energy between the magnet coils and an energy storage system. The 1152 Mwe of power thus produced makes up losses in the storage, transfer and magnet circuits, and is not included in the generation figures quoted above. 


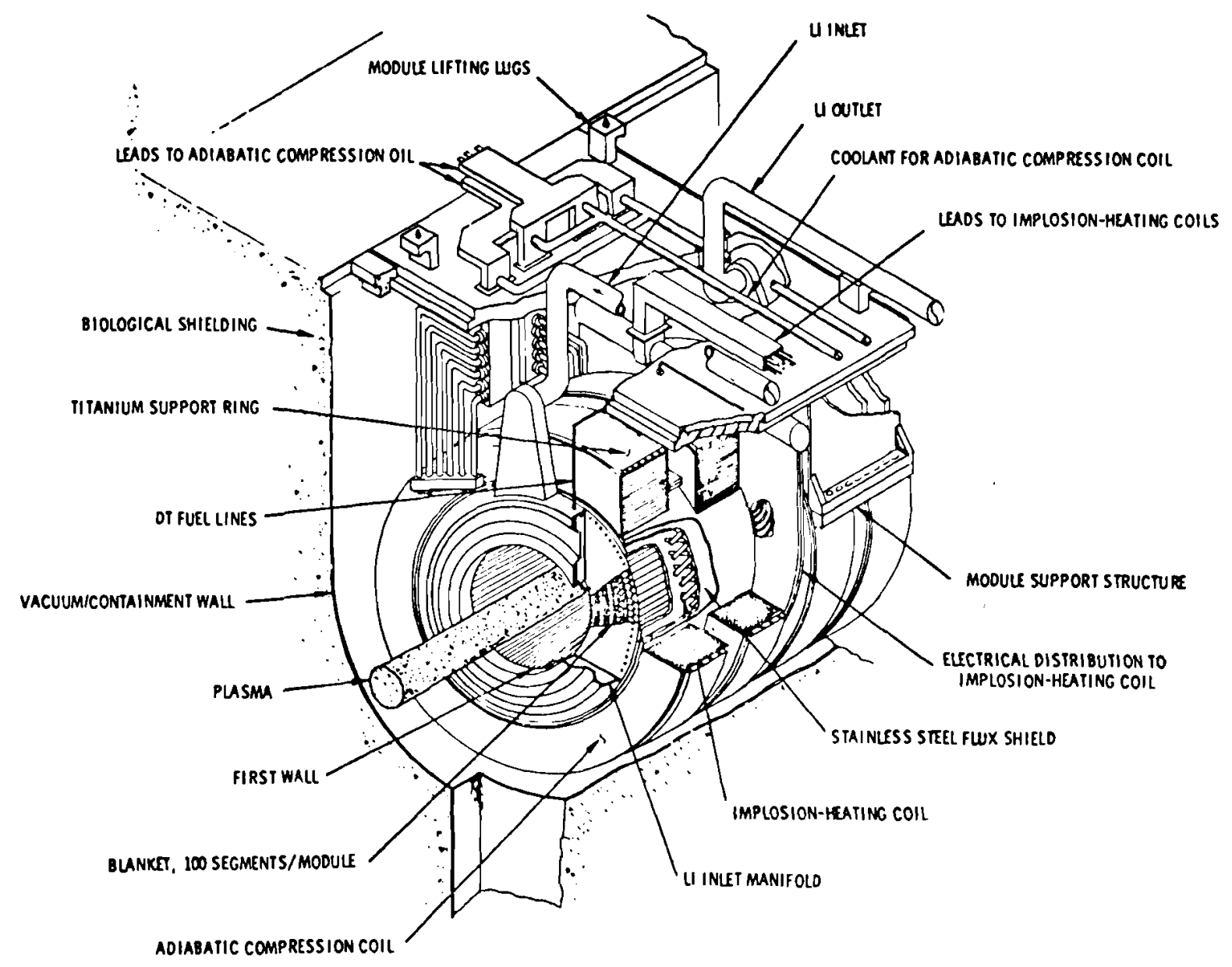

FIGURE 69 A LASL Theta Pi ich Reactor Module

Spent fuel from the thermonuclear burn is purged from the plasma chamber which is filled with fresh fuel between burn cycles. Total flow from the reactor exceeds $240 \mathrm{~kg} /$ day. It is composed of $144 \mathrm{~kg} /$ day of tritium, $96 \mathrm{~kg} /$ day of deuterium and $1.9 \mathrm{~kg} /$ day of helium. It is collected by vacuum pumps, primarily between the thermonuclear burn pulses.

About $1.6 \mathrm{~kg} /$ day of tritium is bred in the lithium coolant and fertile material, at a breeding ratio of 1.11. This is recovered from a cold-leg sidestream of the lithium primary coolant. Lithium tritide is gettered from the coolant by a molten salt which is mixed with it. The coolant and molten salt are separated by centrifuge, and the salt is electrolyzed to recover the tritium.

The total plant inventory of tritium is $3.8 \mathrm{~kg}$, of which $1.4 \mathrm{~kg}$ is in storage. Of the active inventory, $0.35 \mathrm{~kg}$ is in the lithium coolant and fertile material, $0.38 \mathrm{~kg}$ is in the recovery system for bred tritium, and $1.64 \mathrm{~kg}$ is in the fuel recovery and reprocessing system.

Plasma Confinement System for the LASL Design - Ouring the thermor .- -ar buin the plasma is confined by a toroidal magnetic field of $11 \mathrm{~T}$ produced by - muynet coils loca.t. wiound the 352 ii 
torus periphery. This field compresses and heats the plasma to ignition conditions following initial plasma heating by the magnetic implosion field. The coils that produce this fieid are called adiabatic compression coils. Four of these coils are shown on the blanket module in Figure 69.

Current is supplied to the magnetic compression coils midway through the 10 millisecond duration of the implosion heating field. Fstablishment of the full compression field requires $31 \mathrm{mi} 11 i$ seconds, at the end of which the plasma is ignited. The compression field is then held constant for the 70 millisecond duration of the thermonuclear burn.

During the burn, fusion energy is deposited in the plasma by alpha particles produced in fusion reactions. This heats the plasma above the ignition temperature of $6.1 \mathrm{keV}$ (to $15.4 \mathrm{keV}$ at the end of the burn), and causes the plasma to expand against the confining magnetic field. The expanding plasma does work against the confining magnetic field, and this work is directly converted into electrical energy in the circuits which energize the magnet coils. 0ver 10\% of the fusion power released is directly converted to electrical power by this process, which more than makes up for power losses occurring in the nonsuperconducting magnet coils.

To prevent the burning plasma from expanding into the plasma chamber walls, after $70 \mathrm{mil1isec-}$ onds the burn is quenched. The compression field is reduced to $3.2 \mathrm{~T}$ in about 31 milliseconds, allowing the plasma to expand, cool and quench. The field is then allowed to decay slowly over a period of about 1 second. During this time the field contains the plasma at a radius of $46 \mathrm{~cm}$ while the plasma transfers energy to the blanket and cools further. The time history of the compression magnetic field, and of important energy parameters, including direct conversion energy, is shown in Figure 70.

The magnetic compression coils are formed of $1.5 \mathrm{~mm}$ thick, high conductivity copper strap wound into 187 turn pancakes encircling the blanket and the implosion heating coil. They are shown in Figure 69, which indicates the various components of the modules from which the reactor is assembled. Four compression coils encircle each module, two wound clockwise and two wound counterclockwise.

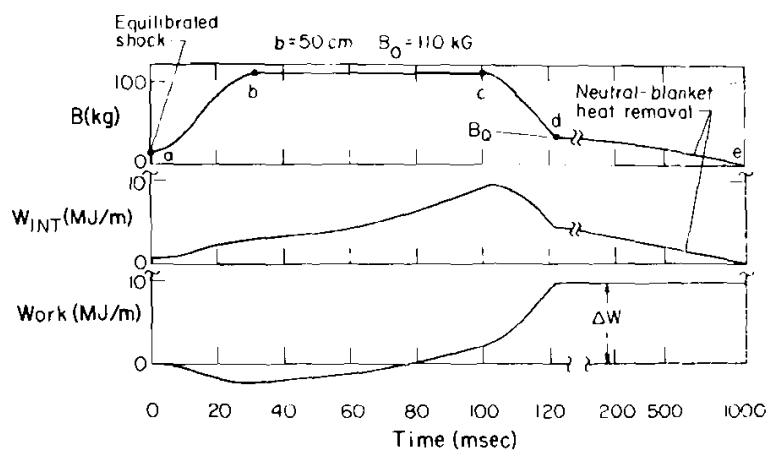

Time history of the magnetic field used for adiabatic compression and time history of important energy parameters. $W_{\text {INT }}$ : Total internal energy of plasma including the contribution from alpha particles; $\Delta W$ : Direct conversion work done by the plasma expanding against the compression field

FIGURE 70 Time History of the Magnetic Field and Energy Parameters for the LASL Design 
Each compression coil is surrounded by a $10 \mathrm{~cm}$ thick support ring of high strength titanium alloy. These massive outer rings support the windings against the large outward magnetic forces which are generated each time the reactor is pulsed. (The choice of titanium is based upon its good fatigue strength.) In addition, these rings also provide support for mounting, moving and positioning the blanket modules. Figure 71 shows a cross section through a coil and $i$ ts support ring.

The nonsuperconducting compression coils are subject to both resistive and radiation heating sufficient to raise their temperature $2^{\circ} \mathrm{C}$ per reactor pulse. Consequently, internal coolant passages are provided between the coils (Figure 71) and convective edge cooling is provided at one side. On a time averaged basis $1370 \mathrm{MW}$ of low grade heat must be removed from the coils which operate at approximately $300^{\circ} \mathrm{C}$.

The coolant for the compression coils will be a radiation resistant liquid with high dielectric strength. Organic coolants, water, chlorinated phenyls and oils are under consideration, but no selection has been made.

Establishment of the $11 \mathrm{~T}$ magnetic compression field requires that $62,700 \mathrm{MJ}$ of energy be supplied to the coils. This may be compared with the total energy release per pulse (due to fusion in the plasma and neutron interactions in the blanket) of $38,400 \mathrm{MJ}$, and the gross thermally generated electrical energy per pulse of 14,300 MJ. Since the energy stored in the pulsed magnetic field is about 1.6 times the thermal energy released as a result of each fusion pulse, this energy must be recovered and stored between pulses with high efficiency. Magnetic energy storage in a superconducting set of nested spherical coils is proposed. (8) Mechanical energy storage in the rotation of a homopolar generator operated as a storage capacitor is suggested as an alternative.

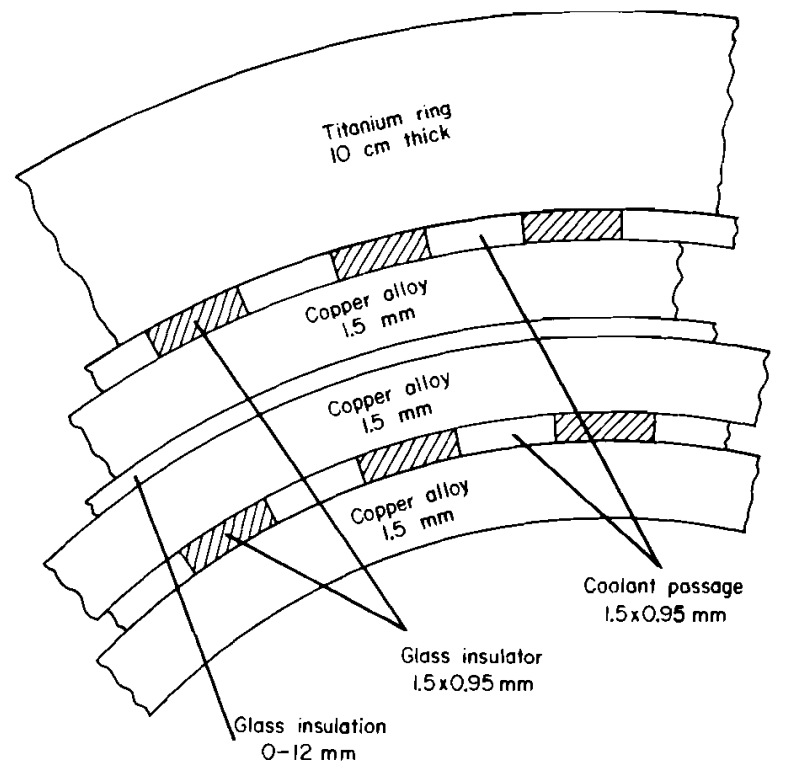

FIGURE 71 Compression Coil Windings, Insulation, and Coolant Ducts in the LASL Design 
Plasma Heating Systems for the LASL Theta Pinch - Two methods of plasma heating, magnetic implosion and magnetic compression, are used. Both depend upon interactions between the plasma and time varying magnetic fields. Separate magnet coils are used to produce the implosion and compression fields, and they are energized sequentially.

Magnetic implosion heating of a preionized plasma is achieved by a very fast rising magnetic field. This $1.4 \mathrm{~T}$ field is established in 0.1 microsecond by suddenly discharging a capacitor bank through a thin coil located between the blanket and the much thicker compression heating coil.

The heating effect of magnetic implosion is achieved as follows. The onset of current flow in the coil establishes a toroidal magnetic field parallel to the plasma axis. This field induces a sheath of current encircling the plasma, which interacts with the implosion field and is driven rapidly inward (imploded) by the field. The magnetic field functions as a piston to drive the plasma inward and the ions are greatly accelerated, and their increased energy increases the plasma temperature.

The temperature increase achievable by implosion heating is determined by the speed at which the implosion can be driven. This is limited by the maximum voltage which can be applied to the coil, which is $650 \mathrm{kV}$ in this design. This yields a plasma temperature of $2.3 \mathrm{keV}$. The power supply and pulse shaping circuitry which drive the implosion have not yet been designed.

Following the implosion the magnetic field of the implosion heating coil is maintained for about $10 \mathrm{milliseconds.} \mathrm{This} \mathrm{contains} \mathrm{the} \mathrm{heated} \mathrm{plasma} \mathrm{during} \mathrm{the} \mathrm{slow} \mathrm{initial} \mathrm{rise} \mathrm{of} \mathrm{the} \mathrm{magnetic}$ compression field, until that field becomes strong enough to begin compression. The implosion heating coil is located between the blanket and the compression coil at a radius of about $90 \mathrm{~cm}$. It is an integral part of the module assemblies of which the reactor is composed (Figure 69).

A proposed construction scheme for the implosion heating coil is shown in Figure 72 . The coil is to be wound diagonally as a double layer of copper strap on a cylindrical shell form. Many conductors operating in parallel are used, and each individual conducting strap passes only a portion of the way around the coil circumference. However, the net effect of the currents passing through all the conductors is equivalent to a circumferential current; thus an axial magnetic field is produced. The conductors and leads are insulated with glass or ceramic and "potted" into a ceramic mold. Internal gas cooling will be provided to remove current and radiation heating.

The energy required by the implosion heating coil is $600 \mathrm{MJ}$ per pulse. Of this approximately $100 \mathrm{MJ}$ is deposited in the plasma as internal energy. After magnetic implosion heating the plasma is further heated to an average temperature of $6.1 \mathrm{keV}$ by the magnetic compression coil. This coil increases the magnetic field to $11 \mathrm{~T}$, compressing the plasma to a radius of $11 \mathrm{~cm}$ (plasma chamber radius $50 \mathrm{~cm}$ ). The energy supplied to the plasma by compression increases plasma particle velocities, thus increasing the plasma temperatures.

Fuel System for the LASL Theta Pinch Design - Fuel is to be consumed at the rate of $1.5 \mathrm{~kg} / \mathrm{day}$ of tritium and $1.0 \mathrm{~kg} /$ day of deuterium. Only $5 \%$ of the plasma charge of $0.9 \mathrm{~g}$ of tritium and $0.6 \mathrm{~g}$ of deuterium undergoes fusion during each thermonuclear burn. Consequently the feed rate 

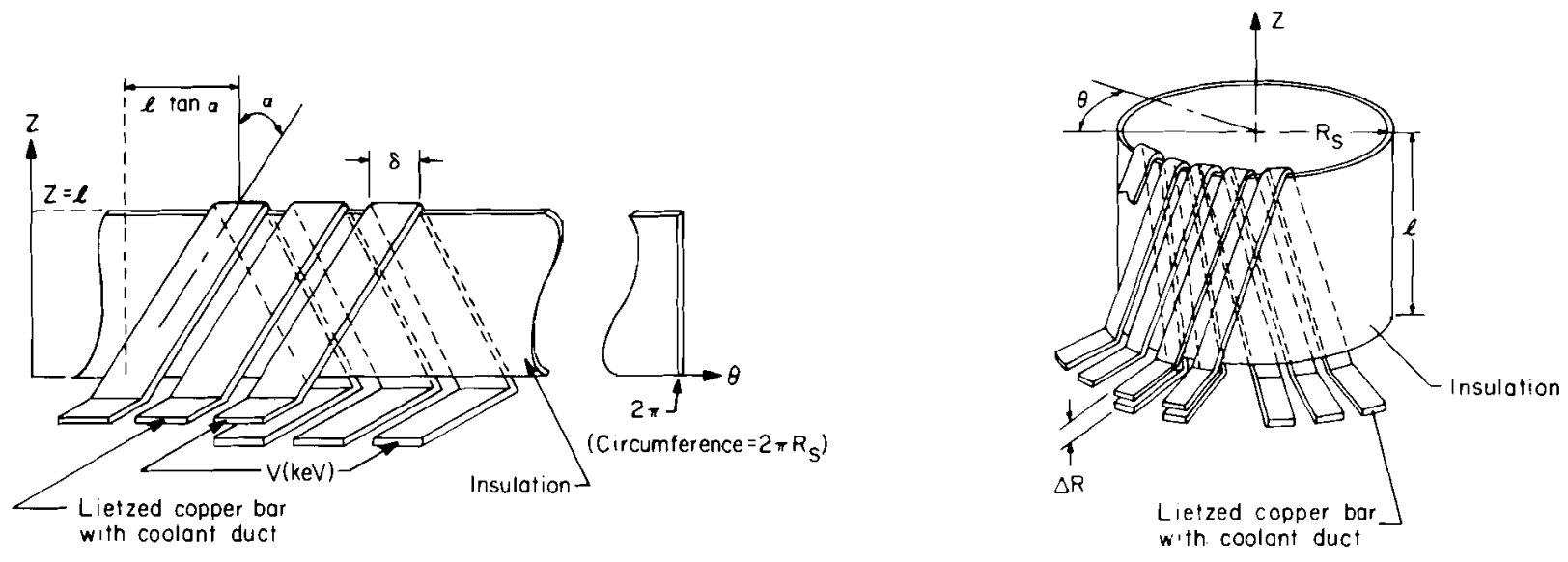

$\boldsymbol{\ell}=$ length of implosion heoting coil

$R_{S}=$ rodius of implosion heating coil

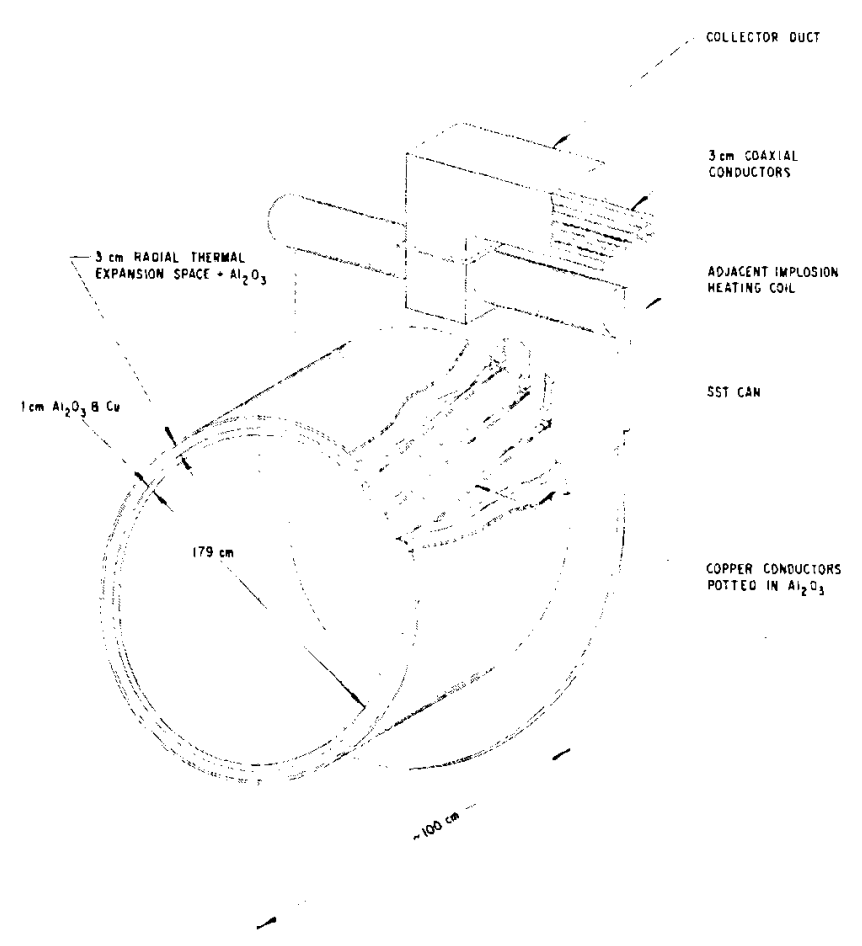

FIGURE 72 Construction Scheme for Implosion Heating Coil in the LASL Design

of fuel for plasma formation is $30.4 \mathrm{~kg} /$ day of tritium and $20.2 \mathrm{~kg} /$ day of deuterium. Additional fuel is introduced into the plasma chamber during the burn to form a gas blanket to protect the plasma from contaminants sputtered from the chamber walls, and also to transfer the plasma energy to the walls in a controlled manner at termination of the burn. Following the burn, neutralized plasma is flushed from the chamber by the addition of even more fresh fuel. Total fuel 
flow through the reactor exceeds $10 \mathrm{~kg} / \mathrm{hr}$. The fuel system functions to separate unburned fuel from recycled plasma, to purify both recycled fuel and bred tritium recovered from the blanket, and to inject fuel gas into the plasma chamber.

Purification of recycled plasma and bred tritium is accomplished by 5 cryogenic distillation units operating in parallel. They must remove a total of $1.9 \mathrm{~kg} /$ day of helium, and somewhat less than $0.5 \mathrm{~kg} /$ day of protium $\left({ }^{1} H\right)$ from the flow. A flow schematic for 1 such unit, capable of processing $3 \mathrm{~kg} / \mathrm{hr}$ of gas, is shown in Figure 73. The nominal molar composition of gas input to the units is $49 \%$ deuterium, $49 \%$ tritium, $27 \%$ helium, <1\% protium, and trace contaminants.

Gas entering the purification units is cooled to a temperature of $50^{\circ} \mathrm{K}$ in an equilabrator/heat exchanger (EQ/HEX), compressed, and input to a fractional distillation column. The liquid exiting from the column contains $T_{2}, D-T, D_{2}$ and $H T$, while the vapor contains $H e, H_{2}$ and $H D$. The vapor is catalyzed to separate HD (and also HT contaminants) and redistilled in a second column. The effluent from this column contains all of the helium, and a minimum of $79 \%$ of the protium from the input stream. Because this effluent will probably contain traces of tritium, additional undefined processing will be necessary.

Equipment and power requirements for the units are expected to be small. The distillation columns are about $5 \mathrm{~m} \mathrm{tall}$ and $15 \mathrm{~cm}$ and $8 \mathrm{~cm}$ in diameter, respectively. The largest heat exchangers (EQ/HEX) are $13 \mathrm{~cm}$ in diameter by $30 \mathrm{~cm}$ long. Operation is expected to require about $60 \mathrm{~kW}$, which may be compared with the plant output of 4100 MWe.

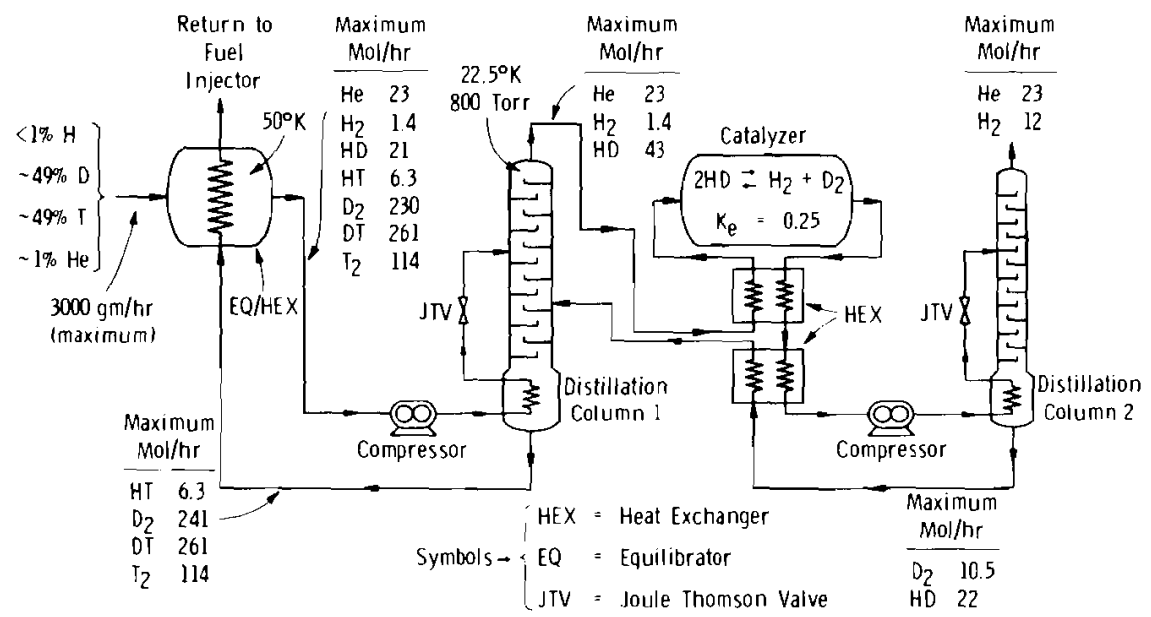

Notes

(1) Enture llow is processed in Column 1.

(2) Each column contains 60 plates $2.5 \mathrm{in.}$ apart. Column 1 is 6 in. in diameter, Column 2 is $3 \mathrm{in}$. in diameter. Both are $-15 \mathrm{ft}$ in height.
(3) Assuming $\sim 30 \%$ efficiency per plate we have 21 theoretical plates (including reboiler) in each column.

(4) Relative volatility of HD compared to $\mathrm{HI}$ is 1.4 giving excellent separation of $\mathrm{H}$ and $\mathrm{T}$
(5) Minimum temperature in Column $\mathrm{l}$ is $20.6^{\circ} \mathrm{K}$ the triple point of $\mathrm{T}_{2}$ l to keep solids out of lines.

(6) Without catalysis of reaction $2 \mathrm{HT} \rightleftarrows \mathrm{T}_{2}+\mathrm{H}_{2}$ $2 \mathrm{~L} \%$ of incoming $\mathrm{H}$ is retur ned to injector.

FIGURE 73 Flow Diagram for Cryogenic Distillation

Unit in the LASL Design 
Fuel is injected into the plasma chamber as a gas through ports $1 \mathrm{~mm}$ in diameter located $2 \mathrm{~m}$ apart around the torus periphery. The gas enters the plasma chamber at the temperature of the blanket through which it passes.

Neutral fuel gas is injected into the plasma chamber during the entire 3 second reactor cycle. At the initiation of a thermonuclear burn, neutral fuel gas is admitted to form a gas blanket between the plasma and the chamber wall. The flow rate through each individual duct is 600 torrliter/second; it is maintained for 30 milliseconds and then by partially closing a valve is reduced to 19 torr-liter/second for the remainder of the cycle.

The neutral gas pressure in the plasma chamber is shown in Figure 74. It rises rapidly from zero at the start of the burn (point a) until the gas inlet flow is reduced (b), and then remains constant during the burn (to point $c$ ) because the vacuum pumps run continuously. When the burn is terminated and the plasma is released and neutralized, the pressure rises; Curves I and II indicate possible scenarios. Following the plasma release the pressure remains essentially constant until the next burn is initiated, due to balanced fuel inlet and evacuation. Blanket for the LASL Theta Pinch Reactor - This blanket provides the necessary functions of tritium breeding, neutron moderation and capture, and heat removal with a minimum thickness (to minimize the required magnetic field energy. Liquid lithium metal is the fertile material for tritium breeding, and as the blanket coolant. Graphite is a neutron moderator and a layer of beryllium metal acts as a neutron multiplier to compensate for enhanced neutron losses of the minimum thickness blanket. Lithium highly enriched in ${ }^{6} L i$ is specified for outer blanket regions where tritium breeding through ${ }^{7} \mathrm{Li}$ reactions is less important.

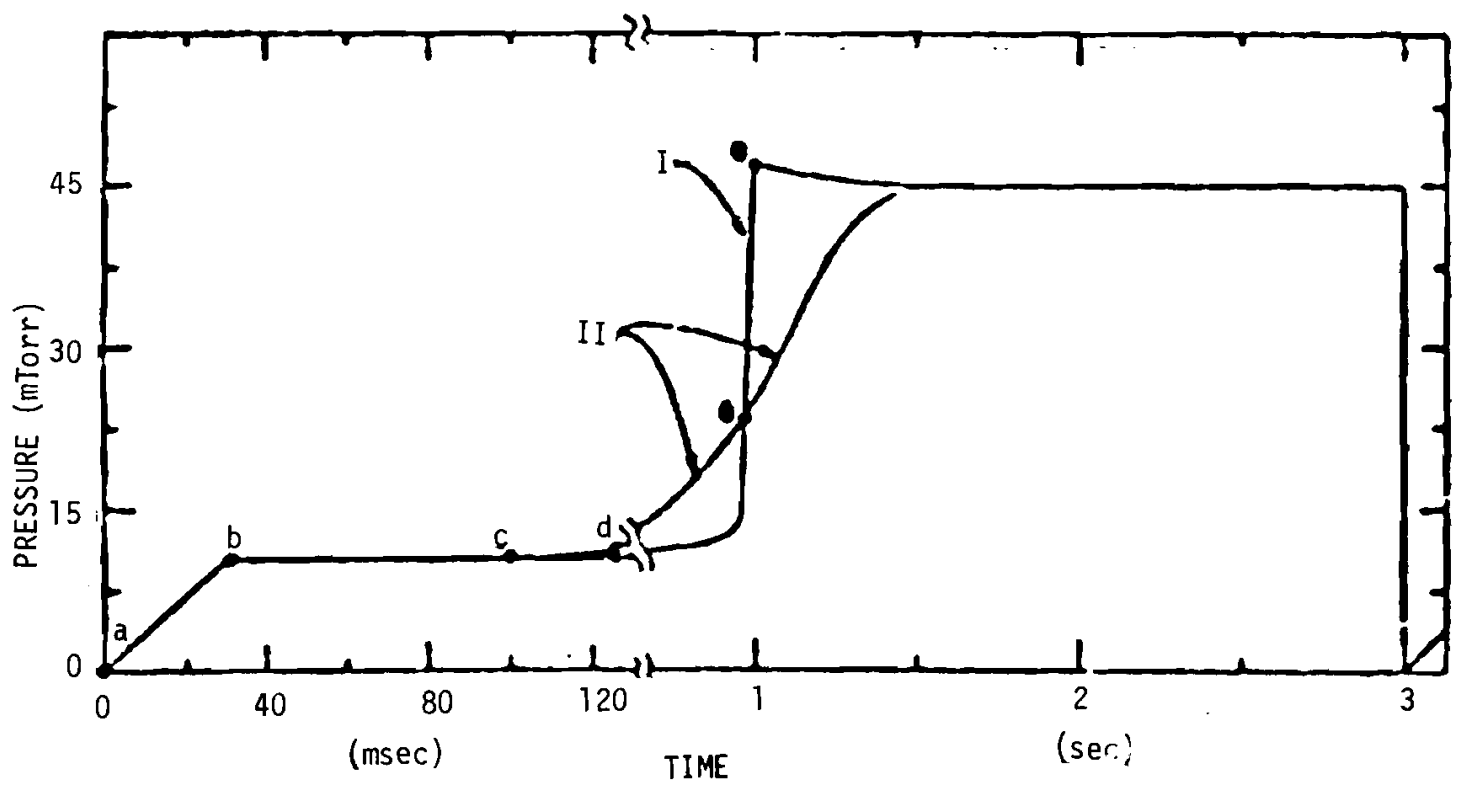

FIGURE 74 Time Variation of Neutral ias Pressure in Plasma Chamber of the LASL Theta Pinch 
Niobium ( $\mathrm{Nb}-1 \% \mathrm{Zr}$ ) is used as the blanket structural material because of its compatibility with liquid lithium, acceptable neutronic properties, high melting point and adequate thermal conductivity.

An insulating coating of alumina $\left(\mathrm{Al}_{2} \mathrm{O}_{3}\right)$ is used on the plasma side of the blanket first wall to prevent short circuiting of the azimuthal voltage that drives the plasma current sheath during implosion heating. Alumina insulation is also specified between blanket constituents and blanket segments to minimize losses due to currents induced by rapid magnetic field changes.

The blanket is located inside of the magnet coils next to the plasma. It is continuous, as theta pinch devices require no divertor. The blanket is only $38 \mathrm{~cm}$ thick, and no shield is located between the blanket and the magnets because the magnets are not superconducting (hence they can tolerate a greater amount of radiation). Structurally, the blanket is an integral part of the modular sections which make up the reactor (Figure 69).

Figure 75 presents a detailed view of a 2 -m-long reactor module. The blanket region is segmented radially and each of the 100 segments is insulated to divide the large azimuthal voltages induced by the rapid magnetic field changes of implosion heating. The radial segments are curved slightly to prevent neutron streaming between the segments.

The blanket first wall is composed of the curved ends of the radial sectors, and is stressed in tension by the pressure of the lithium coolant. It is made of $1 \mathrm{~mm}$ thick $\mathrm{Nb}-1 \% \mathrm{Zr}$ coated with $0.3 \mathrm{~mm}$ of $\mathrm{Al}_{2} \mathrm{O}_{3}$ on the plasma side. The need for an insulating coating for the first wall is unique to the theta pinch concept. The ceramic insulator must be bonded to the refractory metal so that it will not blister, flake or crack despite thermal stresses during the pulsed thermonuclear burn or cyclic fatigue stresses.

The first wall (Figure 75) is followed by liquid lithium coolant which is circulated past a layer of beryllium, past two layers of graphite and through a layer of stagnant ${ }^{6} \mathrm{~L}$. The coolant flow channels are made of $1 \mathrm{~mm}$ thick niobium; beryllium and graphite layers are separately canned in $1 \mathrm{~mm}$ thick niobium. The canned solid materials are insulated from adjacent flow channels by $0.3 \mathrm{~mm}$ of $\mathrm{Al}_{2} \mathrm{O}_{3}$.

The radial blanket sectors are independent of one another and each has its own flow system for the liquid lithium coolant. The lithium is manifolded into each segment at one end of the module and flows parallel to the plasma axis. The flow is first along the vacuum wall of the segment; at the other end of the module it is divided and returned through the outer flow channels. This flow pattern is shown in Figure 76 which also indicates the thickness of the various flow channels and solid blanket components. Figure 77 shows the inlet/outlet and flow return manifolds that serve each of the sectors.

Each of the 176 modules which make up the reactor is a self-contained unit. Adjacent modules are not physically connected together (Figure 75). This is possible because the entire toroidal chamber containing the modules is evacuated. This design concept was selected to facilitate module replacement for maintenance or repair. Each module contains $292 \mathrm{~kg}$ of natural 1 ithium, $278 \mathrm{~kg}$ of ${ }^{6} \mathrm{Li}, 292 \mathrm{~kg}$ of beryllium, 3.9 metric tons of graphite, 2.5 metric tons of $\mathrm{Al}_{2} \mathrm{O}_{3}$ and 2.2 metric tons of $\mathrm{Nb}-1 \% \mathrm{Zr}$ structural material. 


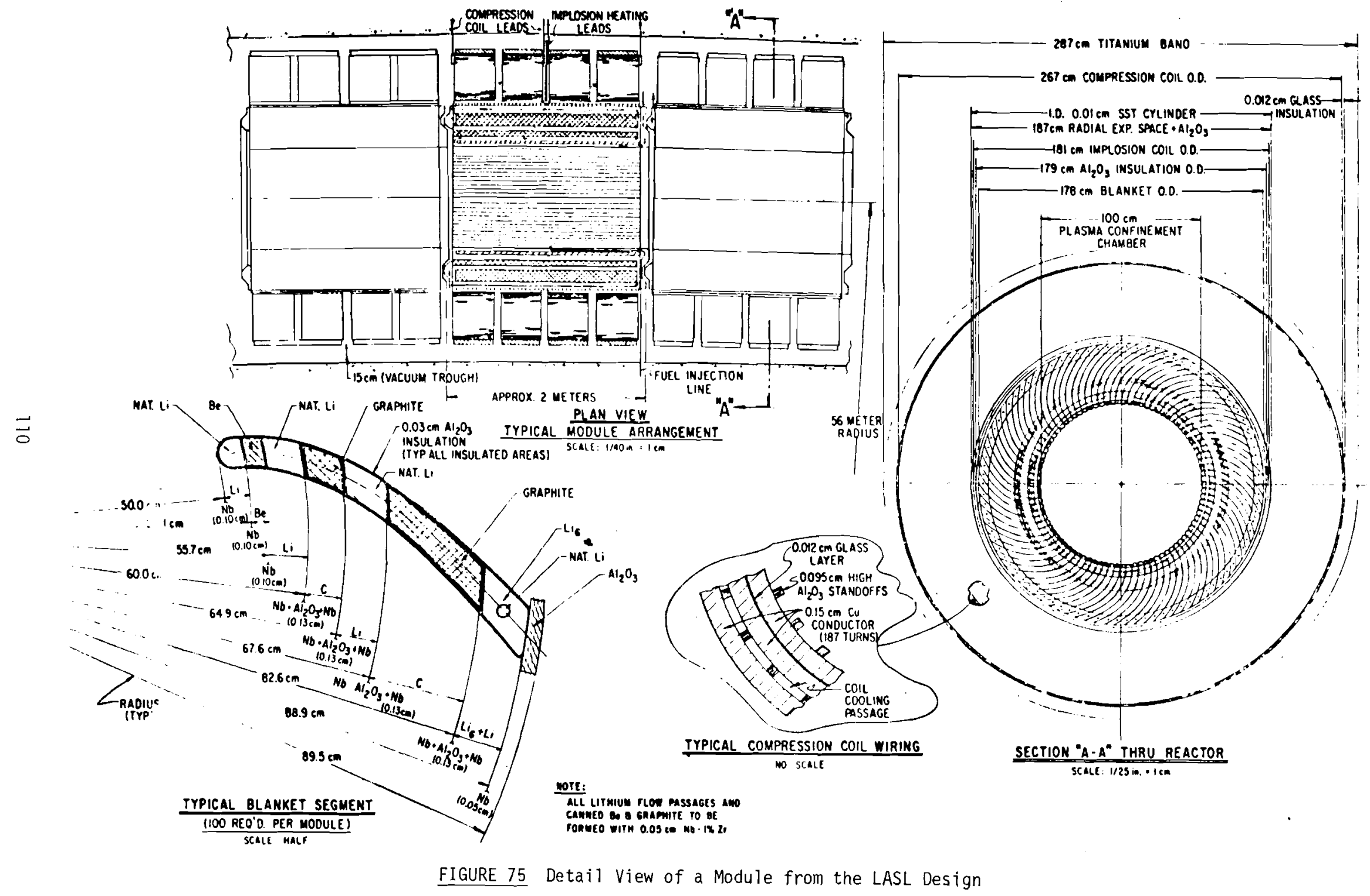




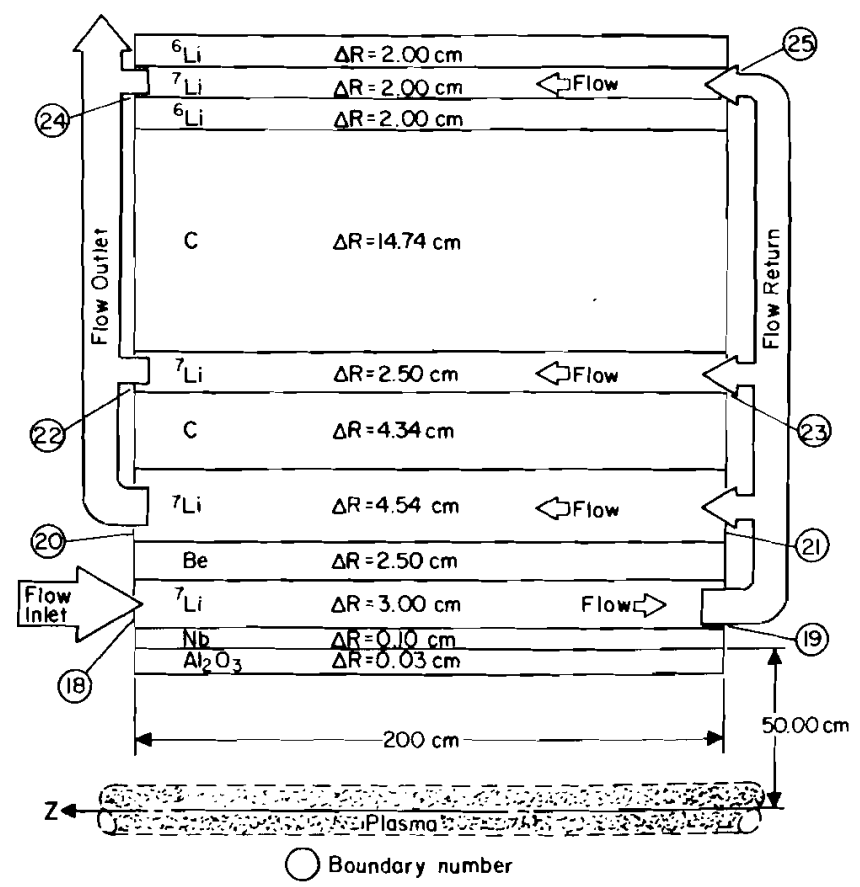

FIGURE 76 Lithium Flow Pattern Within a Blanket Sector of the LASL Theta Pinch

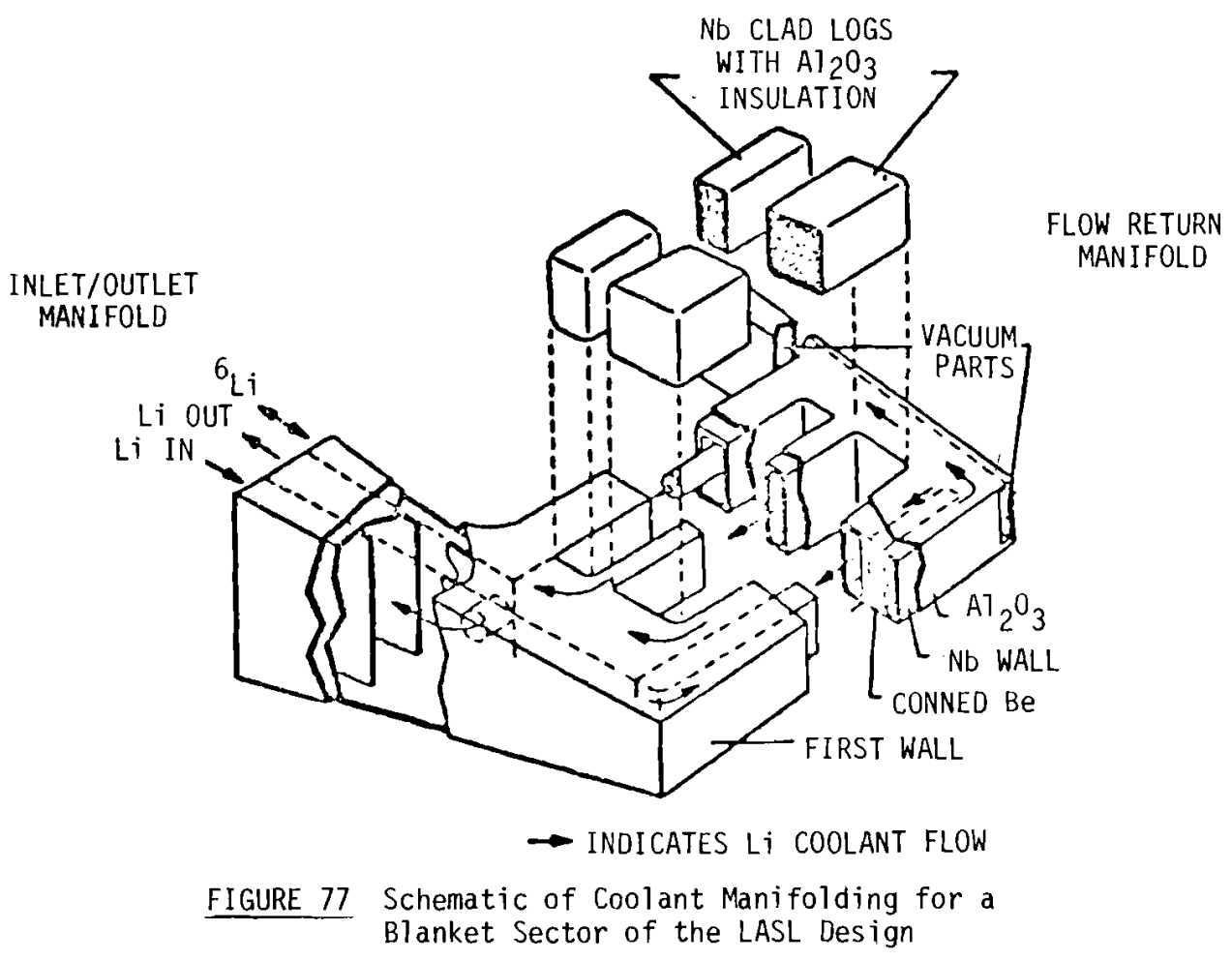


Radiation damage limits the lifetime of the $\mathrm{Nb}-1 \% \mathrm{Zr}$ blanket structure. At the first wall loading of $6.7 \mathrm{MW} / \mathrm{m}^{2}$, blanket modules are expected to require replacement after 5 years in the reactor. If $1 / 5$ of the modules are replaced each year, this will yield 78 metric tons per year of activated structure, 10 metric tons per year of beryllium and 145 metric tons per year of graphite. The activity of the material at shutdown will be $1.2 \times 10^{10} \mathrm{Ci}$, primarily in the

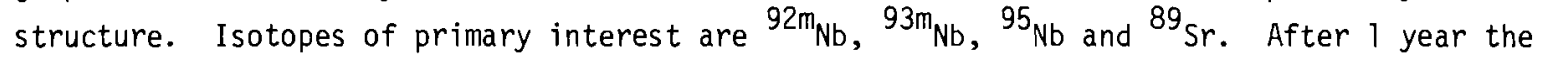
activity will decrease by a factor of about 100 .

Coolant processing to remove impurities is expected to recover several 11 ters per year of corrosion products. The maximum rate of activity handled by this system is expected to be $6 \times 10^{6} \mathrm{Ci} / \mathrm{yr}$.

Heat Transfer System for the LASL Theta Pinch Reactor - Liquid lithium is the primary coolant. It carries the heat that it absorbs in the blanket to external heat exchangers where it is transferred to liquid sodium intermediate coolant. The sodium intermediate coolant carries the heat to steam generators where it is used to raise high pressure steam to drive the turbine-generators (Figure 78).

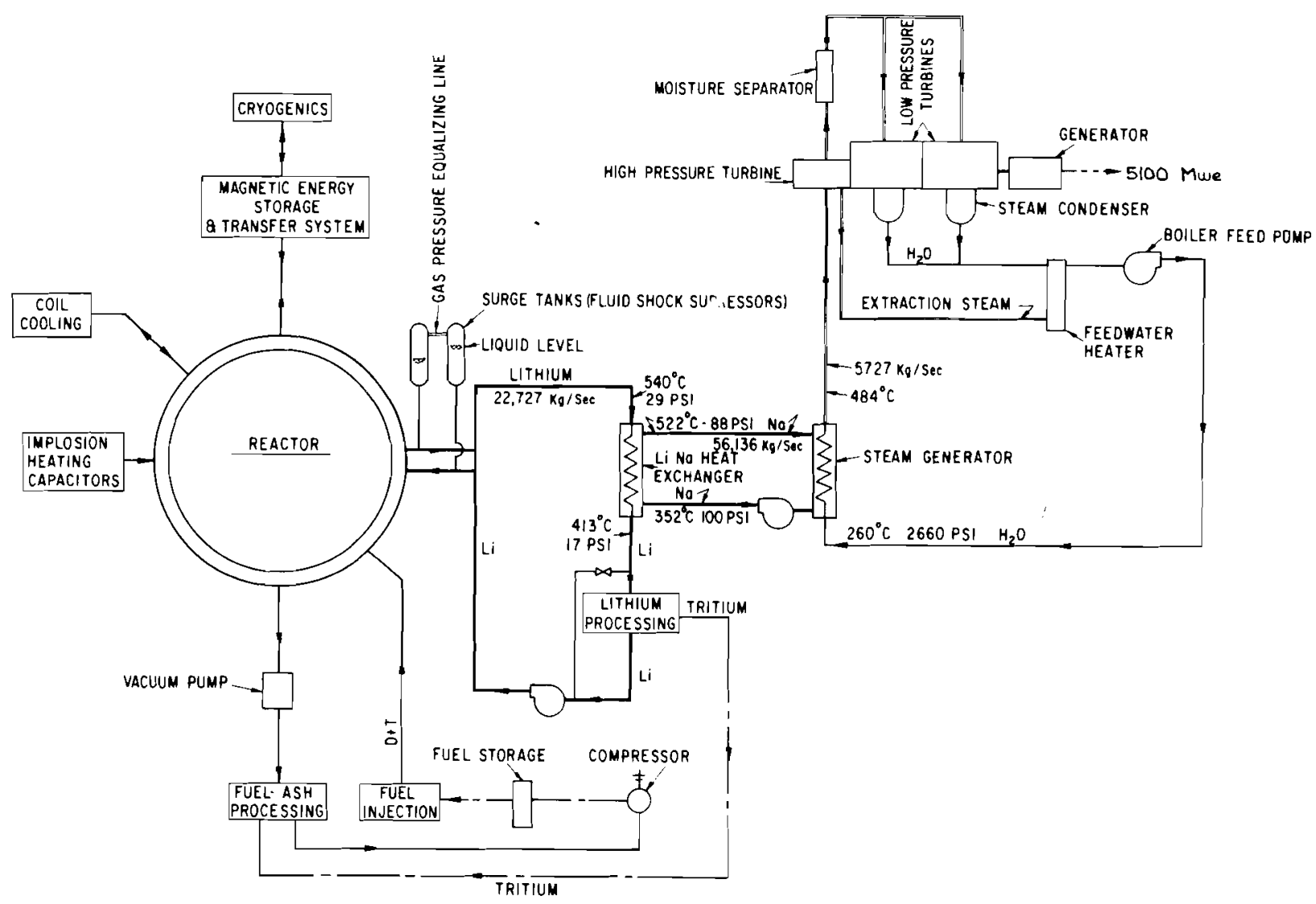

FIGURE 78 Energy Conversion Systeni of the LASL Theta Pinch 
The design requires $8.6 \times 10^{5} \mathrm{~kg}$ of natural lithium primary coolant which is circulated with an average mass flow rate of $8.2 \times 10^{7} \mathrm{~kg} / \mathrm{hr}$. This flow serves 8 parallel independent heat transfer loops.

The lithium primary coolant flow is interrupted by imposition of the pulsed magnetic field. The flow interruption extends after the burn is terminated, while the field is relaxed and the plasma is quenched and cooled. The coolant flows only during the latter 2 seconds of the 3 second reactor burn period. For this reason surge tanks (Figure 78) are provided in the inlet and outlet manifolds serving each of the 176 blanket sectors to suppress pressure surges and temperature variations caused by the flow interruptions. The lithium enters the reactor at a temperature of $410^{\circ} \mathrm{C}$ and a pressure of $3.3 \mathrm{~kg} / \mathrm{cm}^{2}$; average exit conditions are $547^{\circ} \mathrm{C}$ and $2.0 \mathrm{~kg} / \mathrm{cm}^{2}$. Temperature variations of $40^{\circ} \mathrm{C}$ occur during each pulsed cycle in the exit flow to the surge tanks.

Because of the inventory of tritium and activated corrosion products expected in the lithium primary coolant and the possibility of violent chemical reaction between liquid metal and steam coolants, the lithium primary coolant is physically separated from the steam system by intermediate coolant loops. Heat is exchanged to sodium intermediate coolant in 8 shell-and-tube intermediate heat exchangers (IHXs) with lithium on the shell side and sodium on the tube side. The tubes of the IHXs are of pressure-bonded composite construction to limit tritium permeation from the lithium. The tube walls have an outer layer of $0.9 \mathrm{~mm}$ of niobium bonded to an inner layer of $1.0 \mathrm{~mm}$ of Type $304 \mathrm{SS}$. The total heat transfer area of all 8 IHXs is $3.7 \times 10^{4} \mathrm{~m}^{2}$. The lithium exits the IHXs at a pressure of $1.2 \mathrm{~kg} / \mathrm{cm}^{2}$ and is returned to the reactor through niobium piping by single stage centrifugal pumps.

The sodium intermediate coolant loops contain an unspecified amount of sodium which is circulated at a total mass flow rate of $2.0 \times 10^{8} \mathrm{~kg} / \mathrm{hr}$. The sodium enters the IHXs at a temperature of $352^{\circ} \mathrm{C}$ and a pressure of $7.0 \mathrm{~kg} / \mathrm{cm}^{2}$. It exits at $522^{\circ} \mathrm{C}$ and $6.2 \mathrm{~kg} / \mathrm{cm}^{2}$ and is circulated through steam generators. The sodium leaves the steam generators at a pressure of $1.2 \mathrm{~kg} / \mathrm{cm}^{2}$ and is pumped back to the IHXs by single stage centrifugal pumps.

The steam generators for this design are of shell-and-tube construction, with the sodium on the shell side. The tubes are pressure-bonded composites, having a $2.5 \mathrm{~mm}$ thick inner layer of copper sandwiched between two layers of $1.0 \mathrm{~mm}$ thick Incoloy-800. The copper inner layer is provided as a barrier to tritium permeation into the steam system. The total heat transfer area of the 8 steam generators is $4.0 \times 10^{4} \mathrm{~m}^{2}$. Water enters the steam generators at a temperature of $260^{\circ} \mathrm{C}$ and a pressure of $187 \mathrm{~kg} / \mathrm{cm}^{2}$; it leaves as steam at $484^{\circ} \mathrm{C}$ and $171 \mathrm{~kg} / \mathrm{cm}^{2}$. The total steam flow from all 8 steam generators is $2.1 \times 10^{7} \mathrm{~kg} / \mathrm{hr}$.

Electricity Generation System for the LASL Theta Pinch Reactor - Electricity is generated by four tandem-compound quadruple flow turbine sets, each of which drives an $1800 \mathrm{rpm} 22 \mathrm{kV}$ generator. The design of the steam system, including the turbine-generators, was prepared in 1969 for the LMFBR (fission reactor) program. One of the four identical turbine-generator units is shown in Figure 78. 
Superheated steam flows from the eight steam generators to the four turbine-generator units at a total rate of $2.1 \times 10^{7} \mathrm{~kg} / \mathrm{hr}$. In each unit the steam first drives a double flow high pressure (HP) turbine, passes through a moisture separator, and then is divided equally to drive two double flow low pressure (LP) turbines located on the same generator shaft.

Steam is extracted variously from the HP and LP turbines to heat feedwater for the steam generators. Steam is also extracted from the moisture separator outlets to spin the turbines driving the boiler feed pumps which pump the feedwater into the steam generators. Most of the steam passes through the turbines and is condensed at a pressure of 0.8 psia and a temperature of $14^{\circ} \mathrm{C}$. Eight condensors are specified, located at the outlets of the LP turbines. The total condenser area is $1.8 \times 10^{5} \mathrm{~m}^{2}$.

The gross electrical output of the four identical generators is 5100 MWe. Plant auxiliary power requirements are 968 MWe, used as follows: cryogenic refrigerators (superconducting energy storage), $600 \mathrm{MW}$; pumps and compressors, $225 \mathrm{MW}$; magnet coils (nonsuperconducting), 120 MW; vacuum pumps, $13 \mathrm{MW}$; coolant processing centrifuges, $10 \mathrm{MW}$. The net plant output is $4132 \mathrm{MWl}$, produced from 12,000 MWt. The gross thermal efficiency of generation is $42 \%$ and the net plant efficiency is 34\%. The net heat rate is $9912 \mathrm{Btu} / \mathrm{kWh}$. The heat dissipation system has not been designed.

Expansion of the plasma during the thermonuclear burn does work on the confining magnetic field and is directly converted into electrical energy in the magnet circuits. On a time averaged basis direct conversion produces 1152 MWe of power which is not considered in the generation figures presented above. This power exceeds the $671 \mathrm{MW}$ losses expected in storage and transfer of the magnet energy between pulses, and partially makes up ohmic losses in the magnet coils. Although this direct conversion power comes from fusion, it is not deposited in the blanket as thermal power. Consequently it is not included in the 12,000 MWt quoted for the gross thermal power of the reactor.

Spent Plasma Collection System for the LASL Theta Pinch - Partially burned fuel will be pumped from the plasma chamber following termination of the thermonuclear burn. It will be diluted by fresh fuel admitted during the burn to form a neutral gas blanket around the plasma and afterward to purge the plasma chamber. Total flow from the reactor exceeds $240 \mathrm{~kg} /$ day, of which $1.9 \mathrm{~kg} /$ day is helium, and less than $0.5 \mathrm{~kg} /$ day is protium.

The gas in the plasma chamber exits through annular spaces between the blanket modules into the evacuated tunnel which contains the modules. The pumping ducts formed between the modules and the tunnel walls are shown in Figure 79. The separation between blanket modules is $5 \mathrm{~cm}$, and widens to $15 \mathrm{~cm}$ between the magnet coils.

The vacuum pumps operate continuously. During the burn they maintain the pressure of the neutral gas blanket surrounding the plasma at a pressure of 12 mtorr, and afterward they maintain the pressure in the plasma chamber at 46 mtorr during the purge-and-dilute removal of spent plasma. The required pumping speed of $2.3 \times 10^{6}$ iters/second is arhieved by 352 Roots blowers evenly spaced around the torus periphery. A second stage Lackıng pump is provided for each of the first stage Roots blowers. 


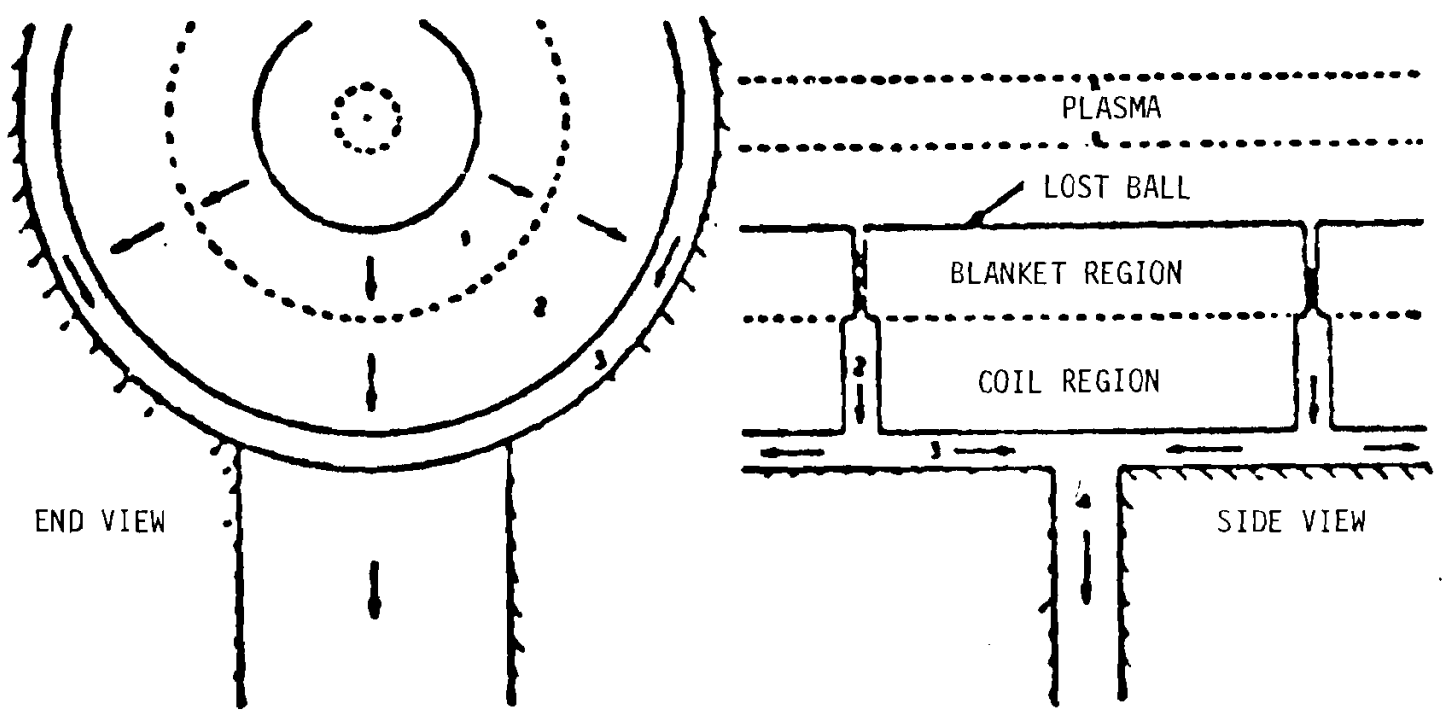

FIGURE 79 Pumping Ducts Required for Each 2-m Module in the LASL Design

Bred Tritium Recovery System for the LASL Theta Pinch - The breeding ratio of tritium in the blanket lithium is 1.11 . The $1.6 \mathrm{~kg} /$ day of tritium bred in the lithium coolant and in the ${ }^{6} \mathrm{Li}$ enriched blanket layer is recovered by liquid gettering. Liquid lithium is mixed with a molten salt that has a higher solubility for lithium tritide than the pure lithium. The liquids are then separated by centrifugation and the molten salt is processed to recover the dissolved LiT (Figure 80).

About $10 \%$ of the flow of the low temperature leg of the primary coolant loop is diverted for processing. The lithium is piped into a molten salt contactor (Figure 81) along with an equal amount of molten salt. Within the contactor, the liquids are mixed to achieve an equilibrium separation of LiT. They are then separated by centrifugal action. The nolten salt is a eutectic mixture of lithium chloride and potassium chloride. Two hundred contactor units $50 \mathrm{~cm}$ in diameter by $43 \mathrm{~cm}$ high are required. They rotate at $1700 \mathrm{rpm}$ and require 10 MWe for their operation. The molten salt emerging from the contactors is processed to recover the dissolved tritium. The electrolytic processing is shown in Figure 80 . Sparging with deuterium chloride using the reaction $\mathrm{DCl}+\mathrm{LiT} \rightarrow \mathrm{LiCl}+\mathrm{D}-\mathrm{T}$ is an alternative method.

The molten salt contactor is also expected to remove impurities from the coolant. Nitrogen and carbon, assumed present in the "salt-like" forms of $\mathrm{Li}_{3} \mathrm{~N}$ and $\mathrm{Li}_{2} \mathrm{C}_{2}$, are important candidates for this process because of their effects on reactor materials.

This system can be expected to hold the partial pressure of tritium in the rithium coolant to $10^{-10}$ torr. This corresponds to a tritium concentration of $0.5 \mathrm{ppm}$. The tritium inventory of the plant is estimated to be $3.8 \mathrm{~kg}$. The distribution is shown in Table 15 . Tritium flows in the plant are indicated in Figure 82. 


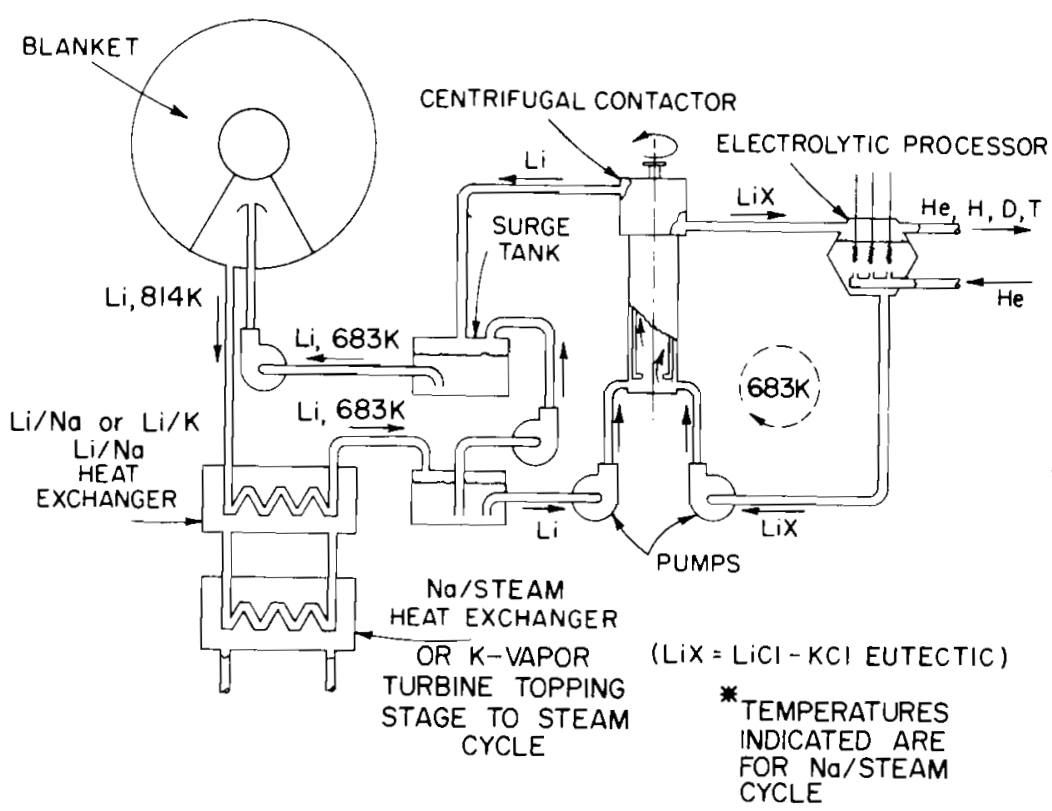

FIGIJRE 80 Bred Tritium Recovery Process for the LASL Theta Pinch

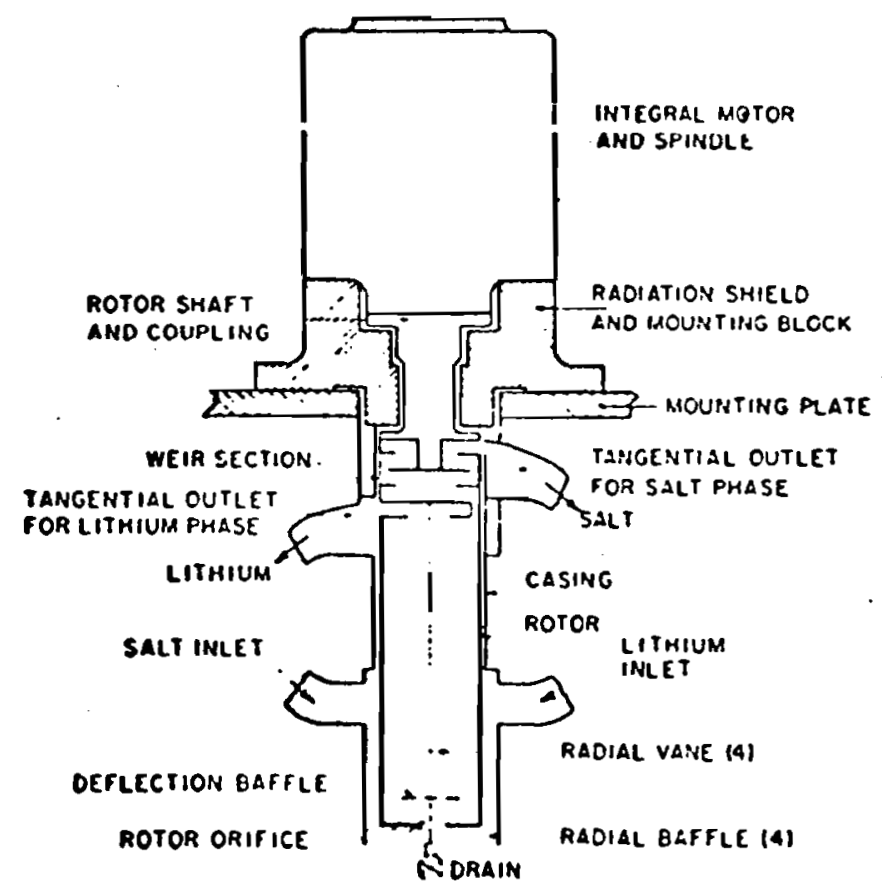

FIGURE $81 \mathrm{Li} / \mathrm{LiCl}$ Centrifuge Contactor for the LASL Theta Pinch 
TABLE 15 LASL Power Plant Tritium Inventory (a)

$\begin{array}{cc}\text { Lithium coolant and fertile material } & \begin{array}{c}\text { Tritium } \\ (\text { kilogram })\end{array} \\ \text { Bred T recovery system } & 0.35 \\ \text { Fuel recovery and processing } & 0.38 \\ \text { Plant active inventory } & \underline{1.64} \\ \text { Storage } & 2.37 \\ \text { Total plant tritium inventory } & \underline{1.43}\end{array}$

a. The tritium stored equals the daily consumption rate. It is $5 \%$ of the daily plasma injection rate, and about $1 \%$ of the daily total tritium flow from the fuel system.

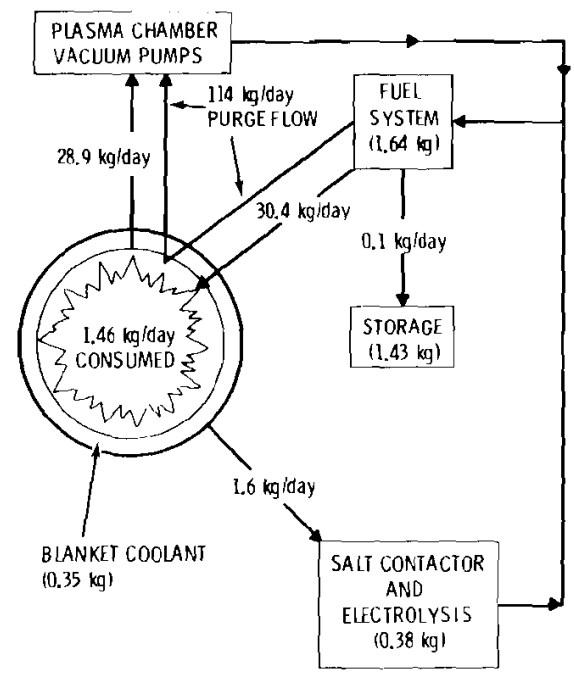

FIGURE 82 Tritium Flow and Inventory for the LASL Design

Containment Building for the LASL Theta Pinch Power Plant - Primary and secondary containment are provided by the reactor building shown in Figure 67. Primary containment is provided by a steel lined evacuated tunnel that contains the reactor modules which are not connected to each other. The tunnel forms the vacuum chamber for the reactor as well as the radiation shield and the containment vessel. The evacuated tunnel communicates with an evacuated maintenance area directly above it which allows module replacement without loss of vacuum. Within the evacuated region high temperature niobium piping is protected from oxidation as is any liquid lithium primary coolant which might leak from the pipes. This region is indicated in Figures 83 and 84 . All hot niobium piping outside of the vacuum region is externally clad with a thin layer of stainless steel for oxidation resistance. It is contained in helium-purged rooms lined with an aluminum tritium barrier. 


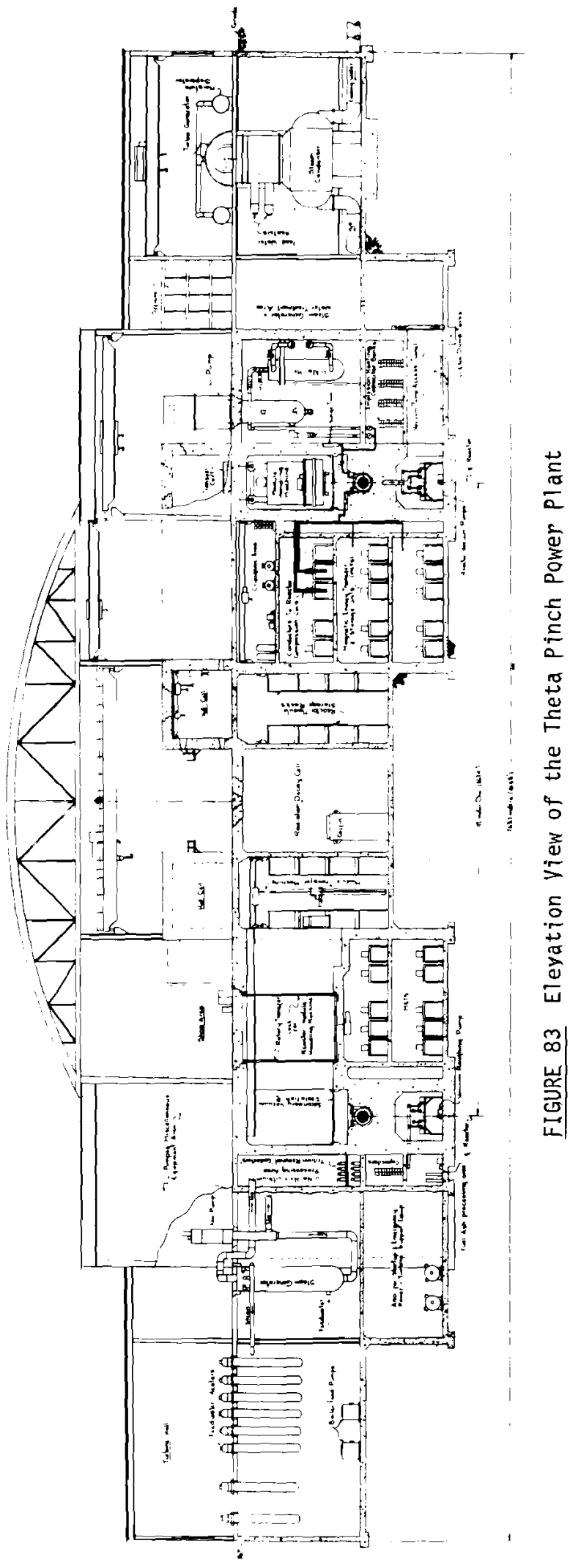




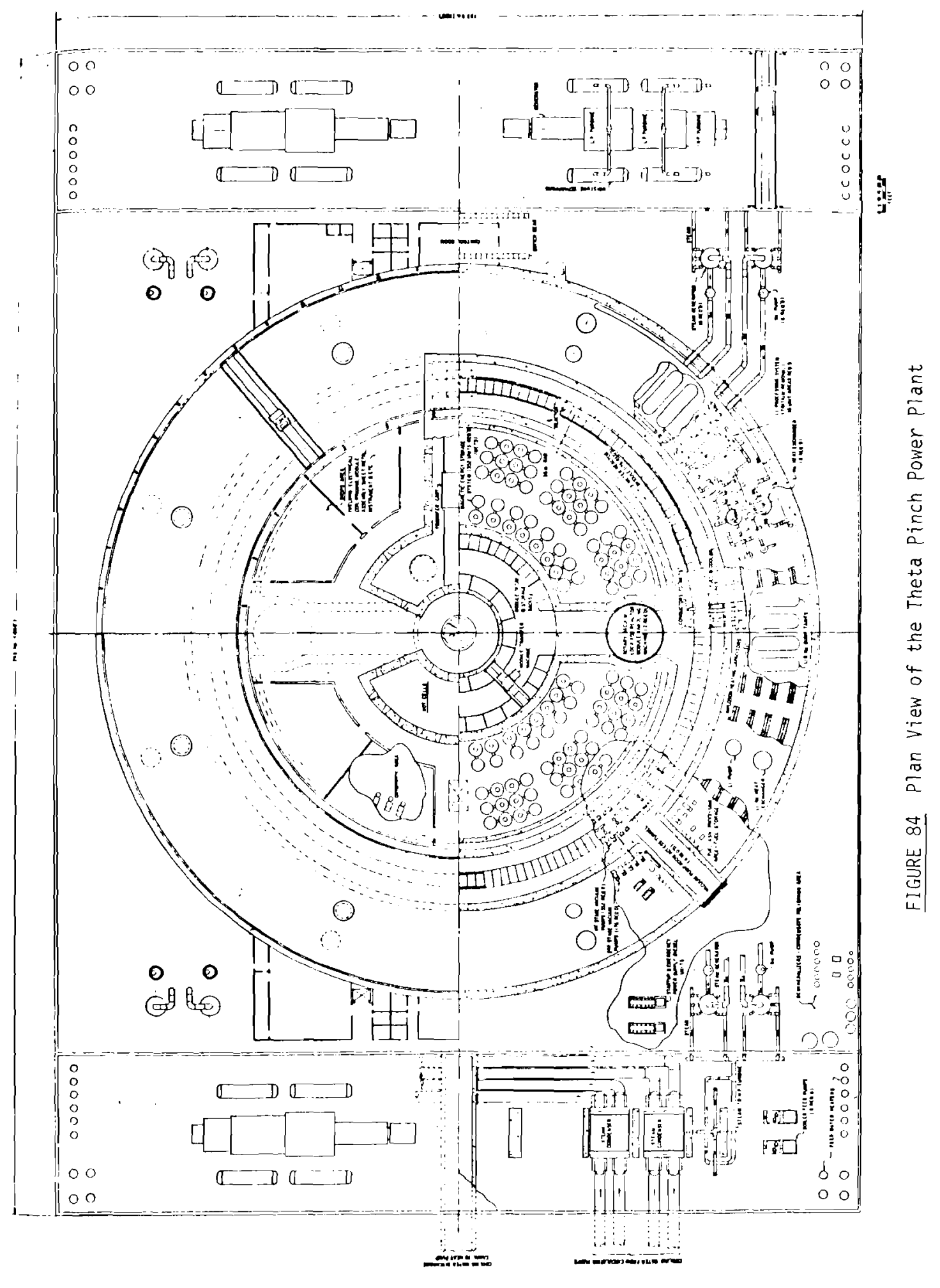


Secondary containment is provided by an outer buffer region lined with aluminum and purged with helium. This buffer region surrounds the primary containment and all rooms with atmospheres having high tritium concentrations or containing components handling high concentrations of tritium.

\subsection{Mirror Magnetic Confinement}

A charged particle in helical motion about a magnetic field line experiences a retarding force as it moves into a region of increasing magnetic field. If this force is strong enough, the particle's motion along the field line will be stopped and the particle will be pushed back toward its source (the rotation about the field line remaining unchanged). This effect may be likened to reflection by a mirror--hence, a localized high-field region of a magnetic field may be termed a magnetic mirror. Charged particle confinement by trapping between two magnetic mirrors is called mirror confinement.

A charged particle whose direction of motion is close enough to the direction of the magnetic field line around which it spirals will penetrate a magnetic mirror. Consequently, for each magnetic mirror there exists a "loss cone" through which particles can escape. Because plasma particles are continually scattered into the loss cone by collisions, mirror confinement is. inherently leaky.

\subsubsection{Livemore Mirror Power Plant Design}

Summary Description - The LLL Mirror power plant ${ }^{(9)}$ produces 170 MWe of net electrical power on a continuous basis from a thermal energy release of $640 \mathrm{MWL}$. The mirror reactor operates continuously allowing uninterrupted generation of electricity. Over half of the gross electricity generation is accomplished by the direct conversion of the kinetic energy of leaking plasma to electricity. The overall layout of the mirror reactor and the direct conversion expander/ coilector structure is shown in Figure 85.

The reactor is cooled by molten lithium metal which also functions as a neutron moderator and a fertile material to breed tritium fuel. This primary coolant exchanges heat to a helium gas intermediate coolant which is used to generate steam to drive turbine-generators.

Major power plant systems and their functional relations are shown in Figure 86 . The reactor is located within a massive spherical stainless steel structure. This structure (Figure 87 ) and the connected fan-shaped structure housing the direct convertor are evacuated and provide containment for the reactor. The lithium primary coolant does not leave this containment building. The diameter of the reactor shell is $32 \mathrm{~m}$. The plasma chamber shape is complex due to the mirror magnetic field configuration. However, the fusioning plasma is ellipsoidal. The shortest radial distance from the plasma center to the blanket is $4.4 \mathrm{~m}$.

Plasma confinement is achieved by two superconducting magnet coils (Figure 87). The superconductor material has not been determined. The magnetic field lines which determine the paths of plasma particles are shown in Figure 88. Also shown is the complex blanket configuration requtred to surround the plasma without blocking the moticn of plasma particles. The maximum arld plasma center magnetic fields are 16.5 and $5.0 \mathrm{~T}$. The mirror regions occur where the field 1 ines pass through the magnet coils. The mirror field strength is $15.0 \mathrm{~T}$. 


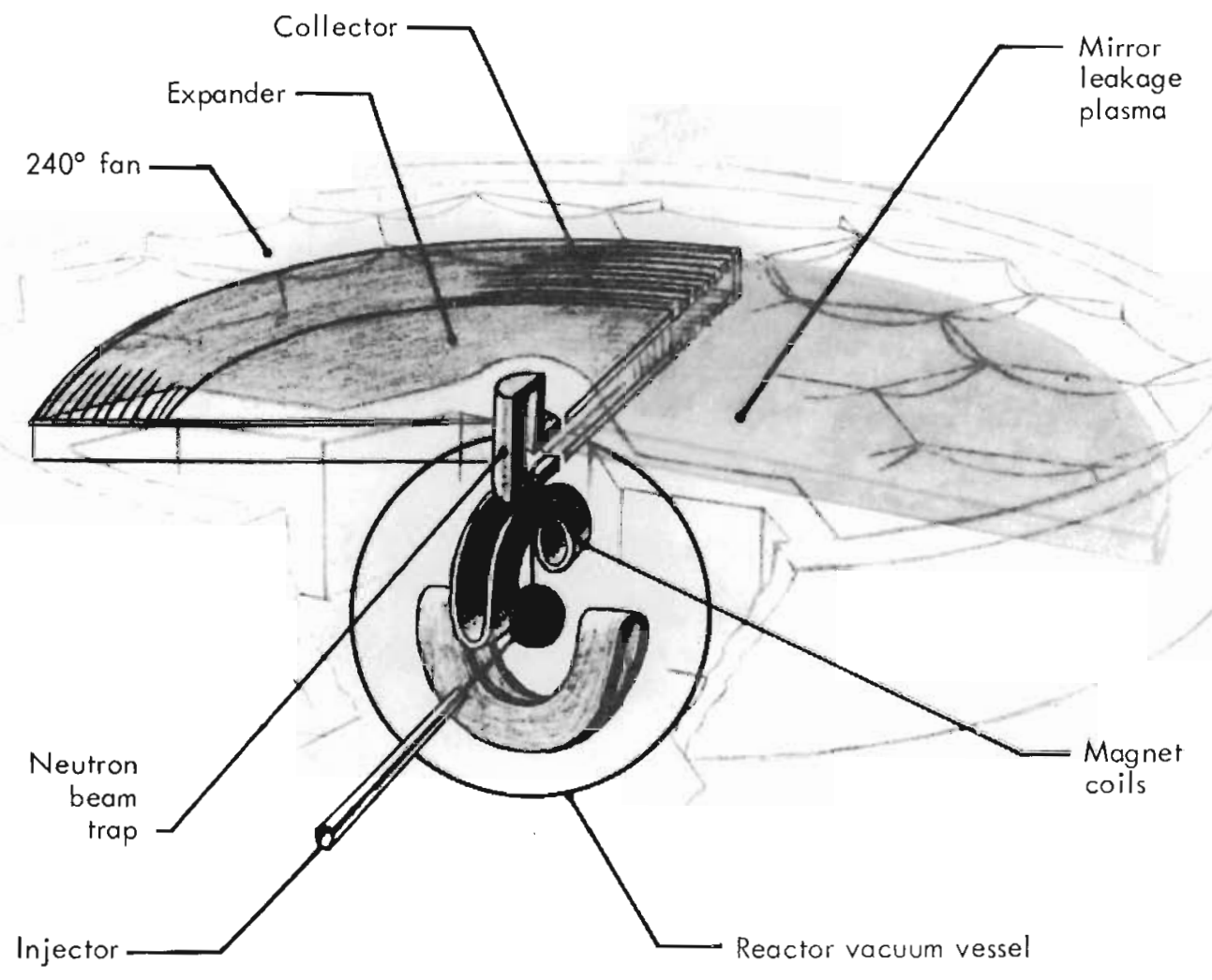

FIGURE 85 Conceptual LLL Mirror Reactor with Direct Conversion

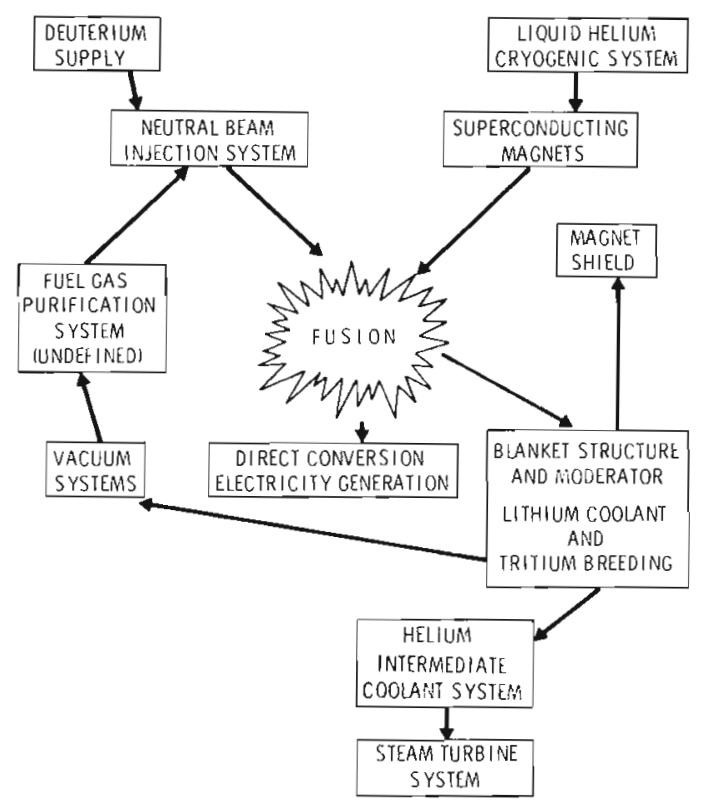

FIGURE 86 Functional Relations Between systems of the LLL Mirror Power Plant 


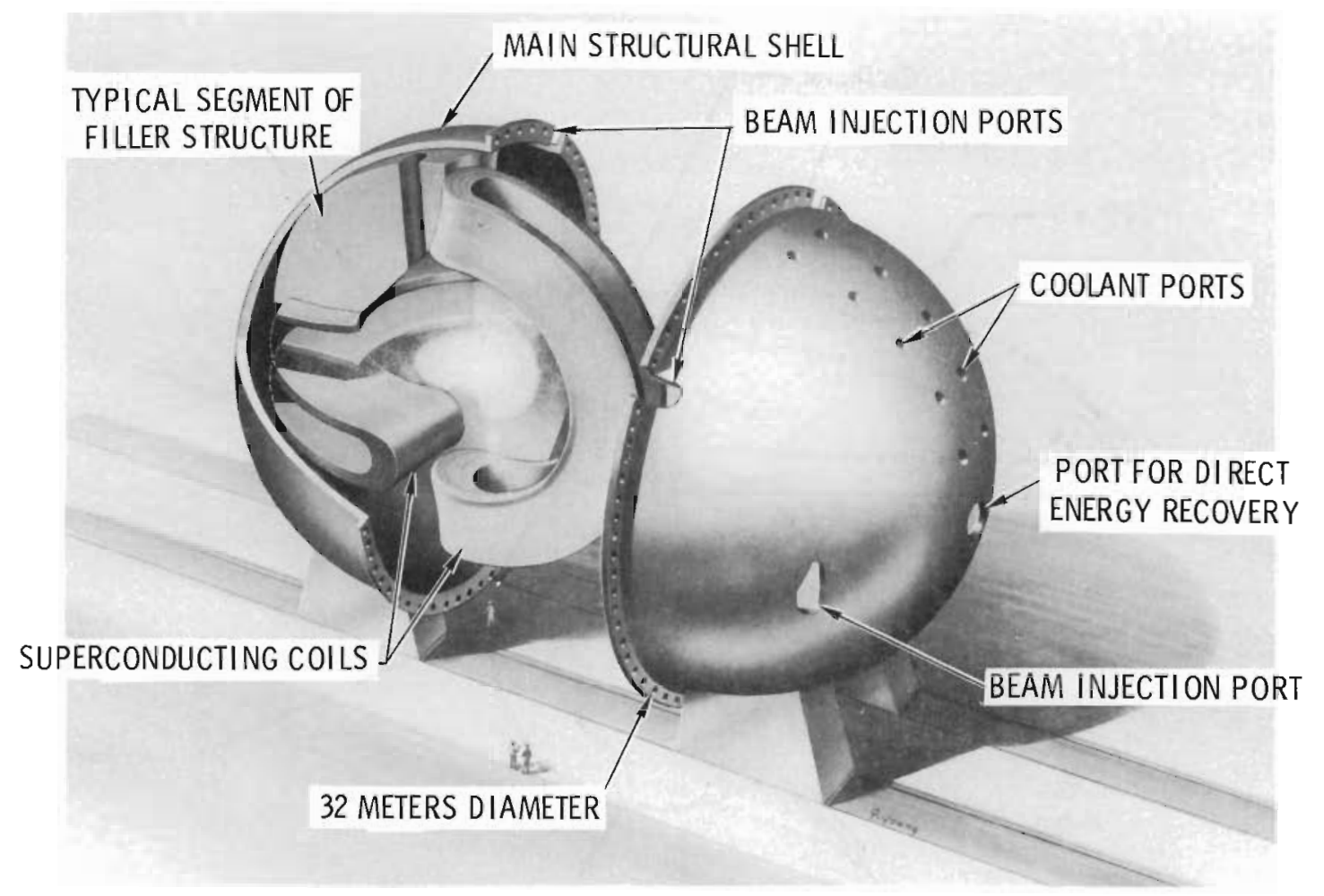

FIGURE 87 Cutaway View of the LLL Mirror Design

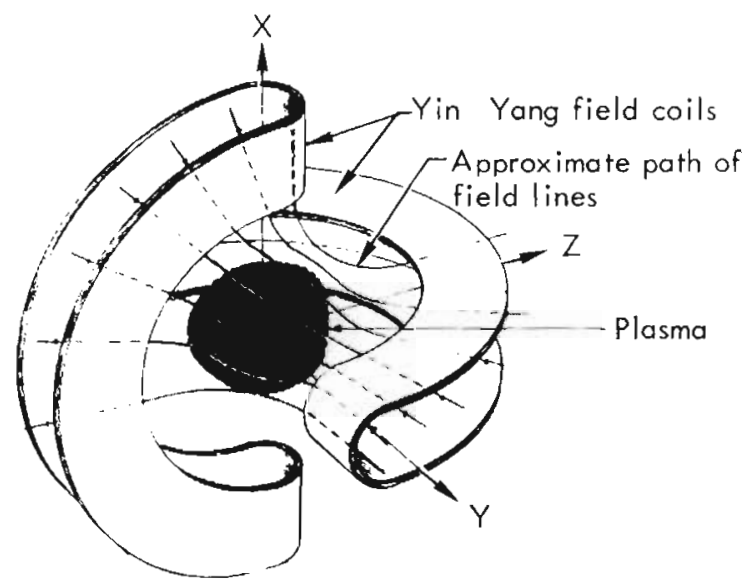

a. Magnet configuration

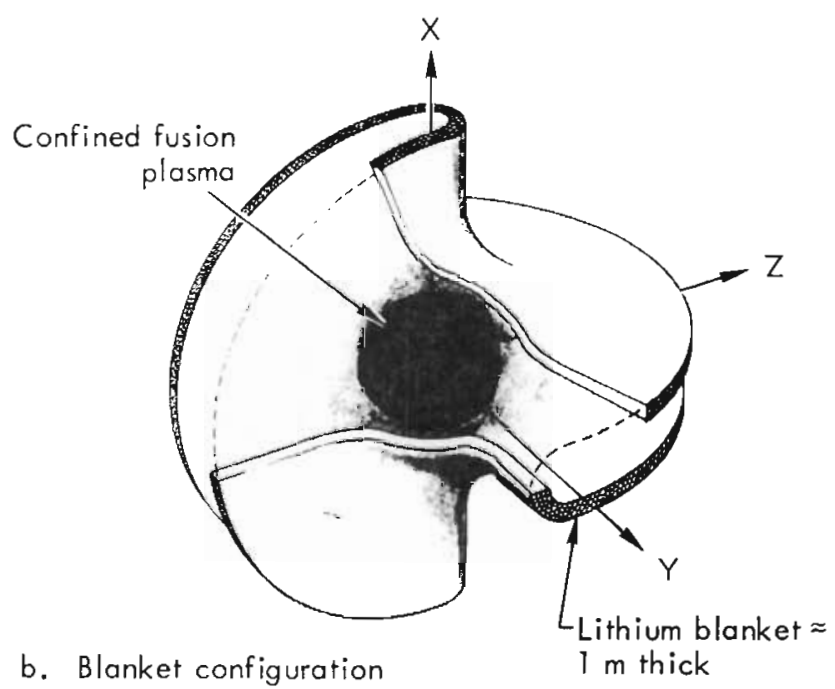

b. Blanket configuration

FIGURE 88 Magnet and Blanket Configuration of the LLL Design 
Weakening the magnetic field in a portion of one mirror region allows selective leakage of escaping plasma. This, plus electrostatic stoppering of the other mirror region, allows one direct convertor fan to collect escaping plasma particles. The plasma is heated continuously by the injection of neutral atom beams carrying $490 \mathrm{MW}$ of power. This replaces the energy carried off by escaping plasma particles. The projected injection of 890 amperes equivalent of $550 \mathrm{keV}$ neutral atoms represents a considerable extrapolation of existing technology.

The plasma contains equal numbers of deuterium and tritium atoms. The plasma chamber fuel charge is $0.04 \mathrm{~g}$ of tritium and $0.03 \mathrm{~g}$ of deuterium. The average plasma ion temperature is $620 \mathrm{keV}$. Neutral beam injectors continuously inject fuel into the plasma. The fuel injection rate is $0.9 \mathrm{~kg} /$ day of tritium and $1.0 \mathrm{~kg} /$ day of deuterium. Only about $7 \%$ of the fuel is burned before escaping from the plasma, yielding a fuel consumption rate of $0.08 \mathrm{~kg} /$ day of tritium and $0.05 \mathrm{~kg} /$ day of deuterium. Purification and recycle of unburned fuel has not been designed.

Energy collection and tritium breeding take place in a $1.0 \mathrm{~m}$ thick blanket located between and within the magnet coils, adjacent to the plasma. Further attenuation of particles and radiation is provided by a $1.0 \mathrm{~m}$ thick shield located between the blankets and the superconducting magnets. The evacuated interior of the containment shell provides thermal insulation between blanket shield and cryogenic magnets. The blanket is composed of many stainless steel tubes carrying liquid lithium metal coolant. Where the tubes surround the plasma, the inner $30 \mathrm{~cm}$ of blanket consists only of lithium-carrying tubes. The outer $70 \mathrm{~cm}$, however, contains graphite neutron moderator in addition. Graphite is omitted in the mirror regions where the tubes enter the coils.

Radiation induced embrittlement of the stainless steel tubes will require their replacement. Although blanket lifetime has not been estimated, 2 and 10 year lifetimes are postulated for the inner and outer blanket region to allow estimates of waste production. An average rate of solid waste production of 44 metric tons per year results.

The lithium/helium/steam coolant loop has been designed only conceptually. Blanket and coolant temperatures are not specified. The lithium is circulated only within the blanket by electromagnetic pumping. Heat exchange to the helium coolant takes place within the mirror regions of the magnet coils.

A total of 750 MWe of electricity is generated by direct and thermal conversion. The steam system generates 320 MWe at an assumed thermal efficiency of $45 \%$. The direct conversion system generates 430 MWe at an assumed efficiency of $70 \%$. Recirculation of 580 MWe, most of which goes to the neutral beam injectors, leaves 170 MWe for export. Net plant efficiency is $27 \%$.

About $0.09 \mathrm{~kg} /$ day of tritium is bred in the coolant/fertile material at a breeding ratio between 1.0 and 1.2. It permeates through the blanket tubes into the evacuated interior of the reactor where reactor vacuum pumps collect it for transfer to the fuel system. Tritium inventories have not been determined. Information on the diffusion of tritium from lithium flowing in magnetic fields is unknown. 
Plasma Confinement System for the LLL Mirror Concept - The mirror confinement field is established by the superconducting Yin Yang magnet coils. The magnetic field lines pass through each of the coils and fan out as shown in Figure 88. The mirror regions--where the field is strongest--occur where the field lines are pinched together between the coil faces as they pass through. In the central region, where the plasma is located, the field lines are convex toward the plasma and the field strength decreases toward the plasma center (magnetic we11). These field features are important from the standpoint of plasma stability.

The mirror regions are located in the middle of the coil faces, along arcs of radius $10 \mathrm{~m}$ from the plasma center. The coils will be $60 \mathrm{~cm}$ thick (Figure 89) and will be superconducting. The total coil weight will be 8800 metric tons. The coils will each carry an equivalent current of $140 \mathrm{MA}$ at a current density of $3.5 \mathrm{kA} / \mathrm{cm}^{2}$. They will produce a magnetic field at the plasma center of $5.0 \mathrm{~T}$, and a maximum field in the superconductor of $16.5 \mathrm{~T}$. The field at the mirrors is $75.0 \mathrm{~T}$, yielding a mirror ratio of 3.0 .

The magnetic field strength is weakened by about $10 \%$ in about $5 \%$ of one of the mirror regions by placing an opposing current solenoid inside the Yin Yang fan. This produces a local minimum in field strength and causes selective leakage of escaping plasma particles through this region. This selective leakage is enhanced by electrostatic stoppering of the other mirror region by providing electrodes to maintain a strong positive electric field to repel escaping plasma ions at the strong mirror position. The efficiency of selective leakage achieved by this combination of methods is expected to be $95 \%$. On1y one direct convertor is required to collect the escaping plasma.

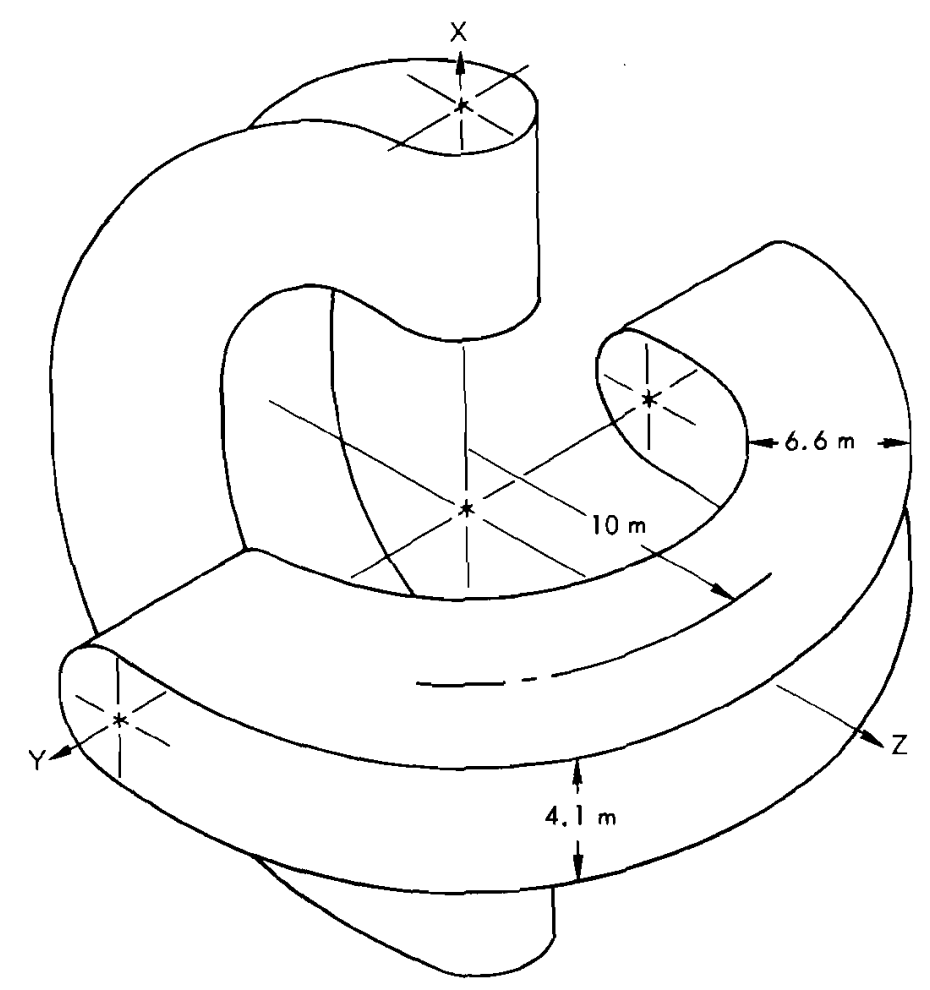

FIGURE 89 Dimensions of Coils in the LLL Design 
Magnetic forces of $2.6 \times 10^{6}$ metric tons will act to separate the coil faces in the mirror regions. These forces are transmitted through compression members to an $80 \mathrm{~cm}$ thick spherical shell structure (Figure 87 ). Stainless steel is used for compression filler (1600 metric tons) and the spherical she11 (2100 metric tons). The magnet coils, compression filler and structural shell are all to operate at cryogenic temperatures because insulation with adequate thermal properties could not support the compression forces. The structure will be insulated by evacuated superinsulation and will be supported by low leak compression material such as epoxy-glass laminate.

Plasma Heating System for the LLL Mirror Design - The present 2XIIB experimental mirror device uses magnetic compression to produce a hot, dense plasma but the reactor startup procedures have not been defined. (9) Energy is required to increase the strength of the confining magnetic field to compress the plasma. Compression increases the plasma energy and that energy is distributed among the plasma particles. This increases their velocities and the plasma temperature. It is quite possible that compression heating may be used at the startup of a mirror power plant to help achieve thermonuclear ignition conditions.

Mirror confinement is inherently leaky. Plasma particles are continually being scattered out of confinement through the mirror regions of the magnetic field. These escaping plasma particles carry off energy that must be replaced or the plasma will cool and the thermonuclear burn will quench. Consequently, continuous replenishment of plasma particles and energy is required. This is accomplished by the injection of energetic beams of neutron fuel atoms.

The neutral atoms are injected into a plasma of density $1.2 \times 10^{14} \mathrm{~cm}^{-3}$ at an energy of $550 \mathrm{kev}$. The average ion temperature of the plasma is $620 \mathrm{keV}$, considerably higher than the 10 to $30 \mathrm{keV}$ temperature of Tokamak plasmas. To maintain a 50:50 D-T plasma mixture requires the injection of 340 amperes (equivalent) of tritium atoms and 550 amperes (equivalent) of deuterium atoms. Thus $490 \mathrm{MW}$ of neutral beam power is continuously delivered to the plasma.

The neutral beam injection system is shown in Figure 90 . Positively charged $D^{+}$ions are first produced in a plasma arc source and accelerated to an energy of $1.5 \mathrm{keV}$. They are then passed through a gas cell containing cesium vapor where less than half of them are converted to negative $D$ ions. These $D^{-}$ions are magnetically separated from the $D^{+}$and $D^{0}$ ions which are then collected and their energy recovered as heat. The $D^{-}$ions are then accelerated to the injection energy of $550 \mathrm{keV}$ and passed through a gas neutralizer cell where most of them are neutralized. Ions which are not neutralized are magnetically separated from the beam and their energy recovered by direct conversion generation of electricity. The beam is then delivered to the plasma; however, some of it penetrates the plasma without depositing its energy. The energy of the penetrating beam is recovered by passing it through a gas cell where the neutral atoms are ionized, and into a direct convertor. This complex injection system is designed to maximize the injection efficiency. It is estimated that this injection system is $88 \%$ efficient; thus $560 \mathrm{MW}$ of electrical power must be continuously recirculated to the system. The achievement of high injection efficiency is important since the net electrical output of this power plant is just 170 MWe. The neutral beam injectors will maintain both the plasma particle and energy content. 


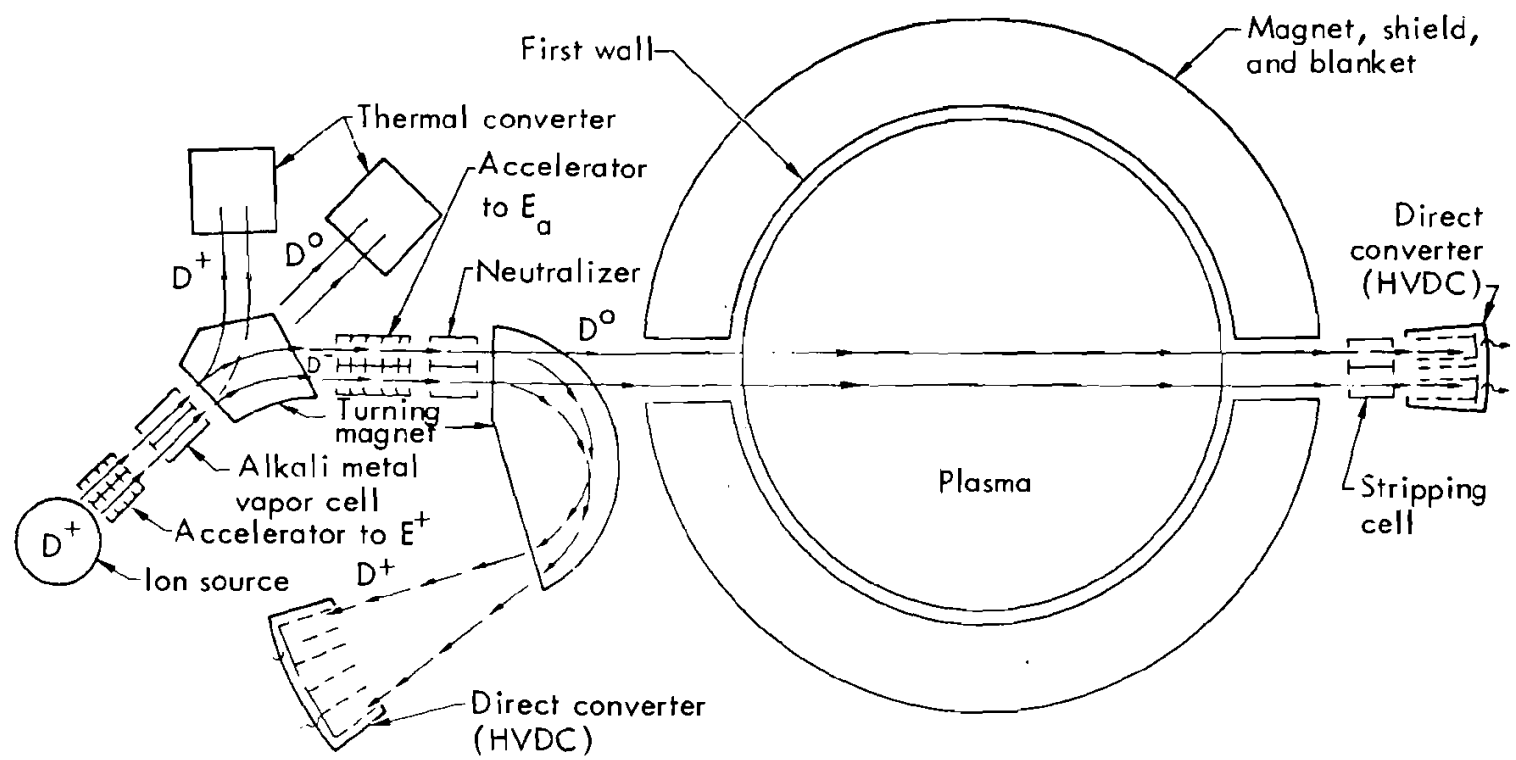

FIGURE 90 The Neutral-Beam Injection System of the LLL Mirror Design

Fuel System for the LLL Mirror Design - Fuel is consumed at the rate of $0.080 \mathrm{~kg} /$ day of tritium and $0.053 \mathrm{~kg} /$ day of deuterium. This consumption represents fusion of about $7 \%$ of the fue 1 in the plasma before it escapes. Unequal loss rates from the plasma are expected for deuterium and tritium. Consequently 1.6 times as many deuterium atoms must be injected as tritium atoms to maintain equal atom densities in the plasma. Fuel injection rates are $0.9 \mathrm{~kg} /$ day of tritium and $0.1 \mathrm{~kg} /$ day of deuterium. The fuel system functions to separate unburned fuel from recycled plasma, to purify it and the tritium bred in the blanket, and to inject the fuel into the plasma as energetic beams of neutral atoms.

About $2 \mathrm{~kg} /$ day of recycled plasma and bred tritium must be purified by an undefined process. This process must remove about $0.1 \mathrm{~kg} /$ day of helium, plus an unidentified amount of protium and other contaminants. Because of the need to separate isotopes of hydrogen, cryogenic distillation will probably be used. Beams of neutral fuel atoms are used to inject fuel into the plasma, which contains $0.039 \mathrm{~g}$ of tritium and $0.026 \mathrm{~g}$ of deuterium.

Blanket for the LLL Mirror Design - The blanket design is a compromise between neutronic requirements, mechanical requirements and economics. Liquid lithium metal is the fertile material for tritium breeding and also the blanket coolant. Graphite is included in outer blanket regions for its moderating properties. Stainless steel is the structural material.

The blanket is composed of a large number of individual stainless steel tubes carrying liquid lithium coolant. These tubes are arranged in a multilayer array. They closely follow the magnetic field lines from the mirror region in the throat of one coil to the mirror region in the throat of the other coil (Figure 88). This flow pattern minimized power losses caused by pumping the liquid metal coolant across magnetic field lines.

Because of the complex geometry of the blanket design, analysis studies have been based on approximations to the actual blanket geometry. The following description is based upon such an 
approximation to analyze the neutronic properties of the blanket. (9) The approximate geometry of the model is shown in Figure 91. The neutron source is the plasma, assumed spherical with a $3.2 \mathrm{~m}$ radius. At the point of closest approach to the plasma the blanket is $4.4 \mathrm{~m}$ from the center of the plasma.

Both the blanket and magnet shield are thicker where they directly face the plasma than in the mirror regions of the magnet coils. The thick region of the blanket is $1.0 \mathrm{~m}$. The first $30 \mathrm{~cm}$ of this region contains only lithium and stainless steel. The remaining $70 \mathrm{~cm}$ also contains graphite for neutron moderation. The thin blanket region contains only lithium and stainless steel.

The shield region is $1.0 \mathrm{~m}$ thick near the neutron source and $0.75 \mathrm{~m}$ thick in the mirror regions. The shield is composed of lead and kerosene for which no containment or support structure is described. The filler and secondary shield material outside the magnets is stainless steel which supports magnetic forces tending to distort the coils. Material composition of the blanket and shield regions are given in Table 16.

The blanket is composed of $6 \mathrm{~cm}$ diameter tubes $(0.3 \mathrm{~cm}$ wall thickness) which follow the paths indicated in Figure 88. The variations in blanket thickness indicated in Figure 91, are obtained because the tubes, which bunch together thickly near the plasma, are spread out over the wide periphery of the mirror regions.

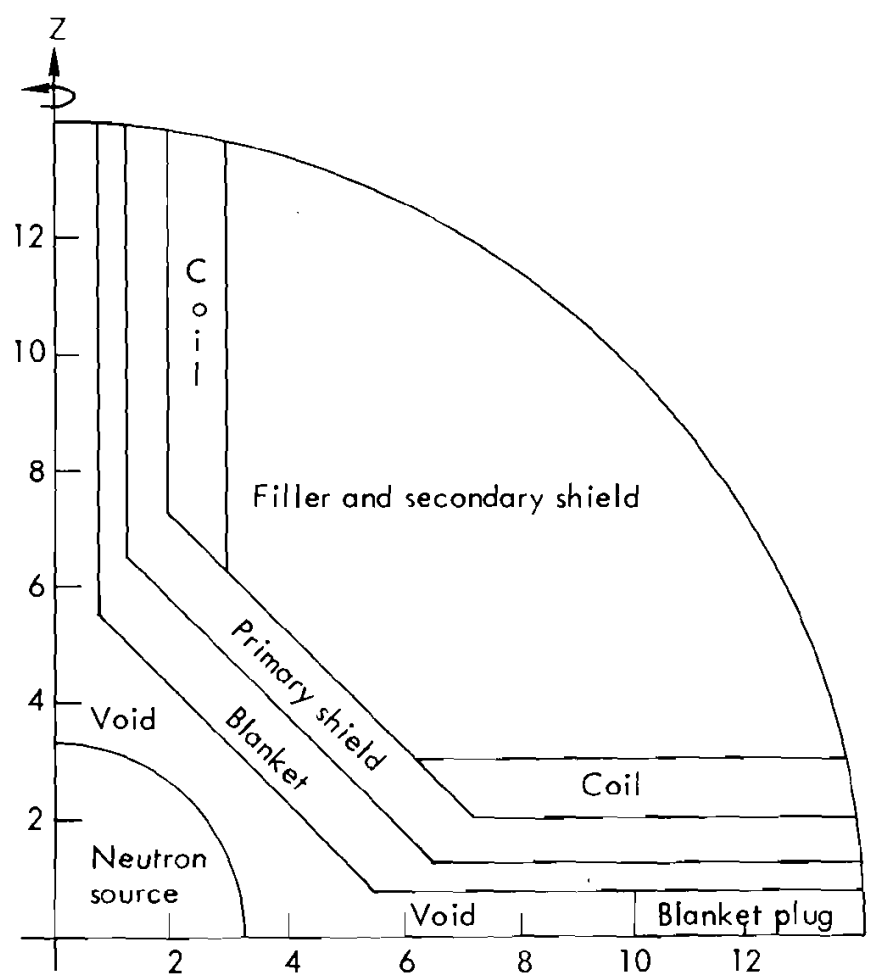

FIGURE 91 Approximate Model of Bianket Geometry IJsed in Neutronic Analys is for the LLL Mirror 
TABLE 16 Material Compositions for the Blanket and Shield of the LLL Design

\begin{tabular}{ll} 
Region & \multicolumn{1}{c}{$\begin{array}{c}\text { Composition } \\
\text { (volume fraction) }\end{array}$} \\
\hline $\begin{array}{l}0.5 \text { deuterium } \\
0.5 \text { tritium }\end{array}$ \\
Inner blanket & 0.85 lithium \\
& 0.05 ssb \\
& 0.10 void \\
Outer blanket & 0.40 lithium \\
& 0.40 graphite \\
& 0.10 SS \\
& 0.10 void \\
Shield & 0.50 lead \\
& 0.40 kerosene \\
& $<0.01$ boron \\
Coil & 0.10 void \\
& 1.00 copper
\end{tabular}

The blanket tubes do not pass through the mirror regions of the magnet coils. They are instead manifolded together there and the lithium flow is collected and led over surfaces where heat is exchanged to helium gas coolant. The lithium is then returned to other blanket tubes via outlet manifolds without leaving the blanket. Tritium extraction from the blanket lithium is achieved by simply diffusing through the blanket tubes into the plasma chamber.

The blanket contains 242 metric tons of stainless steel and 83 metric tons of lithium. The shield contains 1270 metric tons of lead and 74 metric tons of kerosene. This information is not contained in the design document but has been calculated from a spherical shell approximation to the reactor described therein.

The blanket lifetime has not been estimated. An estimate has been made of waste production based upon the postulated replacement of the inner $30 \mathrm{~cm}$ of blanket structure after 2 years in the reactor and replacement of the outer $70 \mathrm{~cm}$ after 10 years. This replacement schedule is similar to that for UWMAK-I. It is postulated because both designs use lithium coolant in stainless steel structure and because the $1.6 \mathrm{MW} / \mathrm{m}^{2}$ average wa 11 loading of this reactor is comparable to that of UWMAK-I $\left(1.25 \mathrm{MW} / \mathrm{m}^{2}\right)$. Average annual replacement rates predicted are: 19 metric tons per year of stainless steel from the blanket inner region and 14 matric tons per year of stainless steel and 11 metric tons per year of graphite from the outer region.

Heat Transfer System for the LLL Mirror Design - Liquid lithium, the primary coolant, carries the heat which it absorbs in the blanket tubes to heat exchangers located in the mirror regions of the magnet coils which transfer the heat to helium intermediate coolant. The helium intermediate coolant is circulated out of the blanket and used to raise steam in an undefined system.

The amount of lithium in the primary coolant system has not been determined. However, from a spherical shell approximation to the blanket, the lithium content was estimated to be $8.3 \times 10^{4} \mathrm{~kg}$. 
The mass flow rate and the blanket temperatures have not been deternined. Lithium flowing in the $6 \mathrm{~cm}$ diameter tubes is expected to experience a bulk temperature rise of $100^{\circ} \mathrm{C}$. The maximum temperature in the $0.3 \mathrm{~cm}$ tube walls will be $25^{\circ} \mathrm{C}$ higher than that of the lithium. Calculations of MHD resistance to coolant flow in the reactor magnetic field predict a pressure drop of less than $100 \mathrm{psi}\left(7 \mathrm{~kg} / \mathrm{cm}^{2}\right)$ for flow between blanket mirror regions.

The stainless steel tubes which carry the lithium are manifolded together in the mirror regions located in the throat of the Yin Yang magnet coils. The lithium flow is collected and led over surfaces where heat is exchanged to the helium intermediate coolant. These surfaces are coated with a refractory oxide, such as alumina, to inhibit permeation of tritium into the helium coolant. One of the manifold heat exchangers is illustrated in Figure 92. Adjacent flow passages

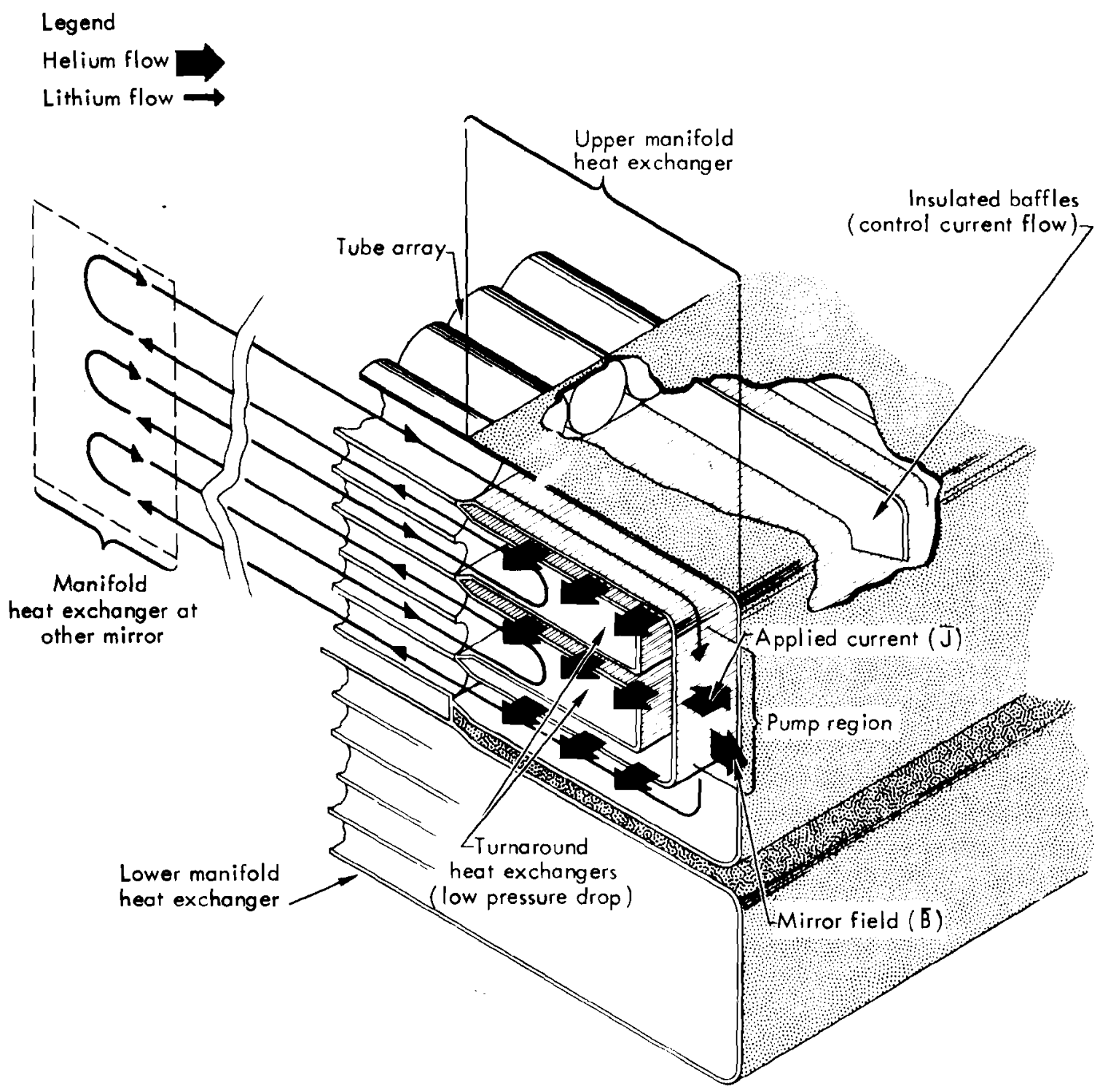

FIGURE 92 Manifold Heat Exchanger for the LLL Design 
are connected by large-flow-area turnaround passages which reduce the lithium flow velocity and minimize MHD losses as the conducting coolant crosses magnetic field lines.

Plasma leakage through the mirror regions is only allowed in about $5 \%$ of the area of one of the mirror regions. Consequently, most of the mirror regions are closed off by the heat exchangers. This is illustrated in the figure, where the "upper" and "lower" manifold heat exchangers handle flows from opposite sides of the plasma chamber. A similar pair of heat exchangers is located in the mirror region of the other coil to return the coolant flow.

The coolant flow pattern lies entirely within the reactor blanket. Pumping of the coolant is accomplished by electromagnetic pumping in one mirror region. A dc current is passed through the lithium coolant within the heat exchangers (Figure 92). The current flows circumferentially around the periphery of the mirror region. In exact analogy with an electric motor, the conductor (coolant) carrying current across a magnetic field experiences a force pushing it in a direction perpendicular to both current and magnetic field, and thus the coolant is pumped.

The pumping current is directed by insulating baffles within the heat exchangers. It flows through the entire $180^{\circ}$ circumference of both the upper and lower heat exchangers, traversing about $48 \mathrm{~m}$ of lithium. Due to the long flow path a pump voltage of $140 \mathrm{~V}$ is required. Tota 1 input power to the pump is estimated to be less than 5 MWe. The helium intermediate coolant loop and the steam system have not been designed.

Electricity Generation Systems for the LLL Mirror Power Plant - Electricity is generated iy thermal conversion and direct conversion of fusion energy to electrical power.

The steam turbine-generator system has not been designed. It is assumed to operate at a gross thermal efficiency of $45 \%$, generating 320 MWe. The thermal input to this sytem is: 520 MWt from the blanket, supplied by the heat transfer system; and 180 MWt from the direct convertor. Heat is deposited on the direct convertor collector plates by impacts of the energetic jons which are collected. This heat ( $180 \mathrm{MWt}$ ) is transferred to the steam system by heliuri-coolet heat pipes which use sodium as the working fluid.

Over half of the gross electricity generation of the plant is accomplished by direct conversion. The kinetic energy of charged particles escaping confinement is recovered by guiding them into a collector region where they encounter strong electric fields established by nigh voltage electrodes. The ions are slowed by the electric fields, and their kinetic energy is converted to electrostatic potential energy. They are then captured and neutralized by the collector electrodes, making their electrostatic potential energy directly available to power the circuits connected to the electrodes. The efficiency of direct conversion is not limited by factors limiting the efficiency of thermal conversion, and an efficiency of $70 \%$ is expected for direct conversion. Consequently, generation of 430 MWe from $610 \mathrm{MWt}$ of escaping charged particle energy is expected, with the remaining 180 MWt supplied to the steam system.

Figure 93 shows a cross section view of the reactor and direct convertor structure. Escaping plasma leaks selectively through only a small region $\left(1.5 \mathrm{~m}^{2}\right)$ of one of the mirrors. The magnetic field lines which the particles follow through this region are subsequen : $y$ turned $90^{\circ}$ 


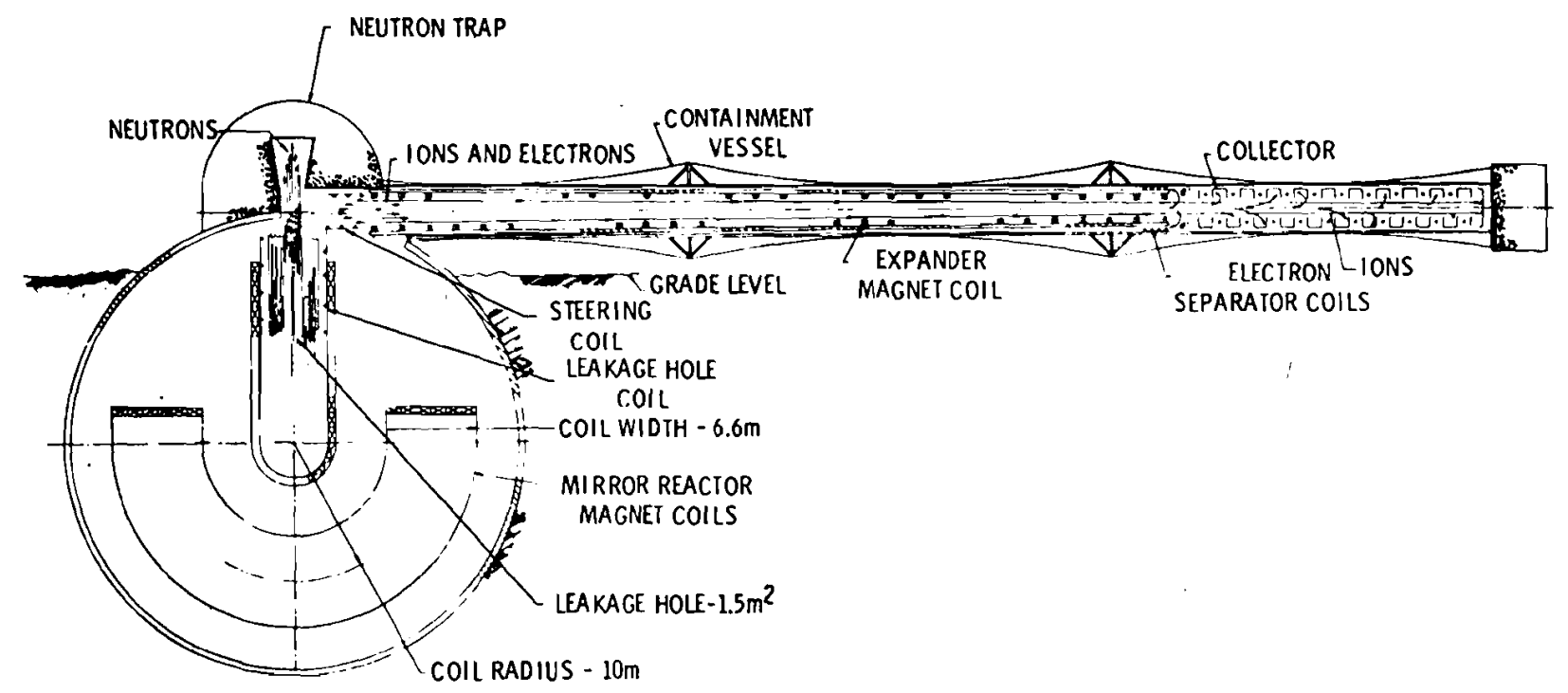

FIGURE 93 Cross Sectional View Through the LLL Mirror Reactor with Direct Convertor

and fanned out into a large fan-shaped vacuum enclosure called an expander. This is accomplished by the magnet coils seen in the figure. The purpose of the turn is to separate the charged particles from escaping neutrons that continue straight ahead into a neutron trap.

The expander fan (Figure 85) makes use of the same basic principle that makes mirror confinement possible. Specifically, an ion spiraling along a magnetic field line in a region where the field strength is changing experiences a force directed away from the high field region. The magnetic field weakens as it is fanned out in the expander and the ions are consequently accelerated toward the collector region. Thus, the expander functions to maximize the recoverable kinetic energy of the ions.

The effect of the expander is to reduce the magnetic field from $15 \mathrm{~T}$ at the mirror region to $1.5 \mathrm{~T}$ at the outer edge of the expander. There, the field lines are diverted out of the plane of the fan so abruptly that the massive ions cannot follow them. The less massive electrons do follow the diverted field lines, however, and they are separated from the beam of energetic positive ions that continue on into the collector region for the direct conversion of their kinetic energy into electrical power.

The expander/collector structure has a radius of $98 \mathrm{~m}$, of which the inner $76 \mathrm{~m}$ is the expander and the outer $22 \mathrm{~m}$ is the collector. The fan has an included angle of $240^{\circ}$. The upper and 10 wer faces of the structure are formed from a series of interconnected, hexagonal unit modules (Figure 85). The clear channel separation between the 'faces is $1.74 \mathrm{~m}$. The surface of each unit is dished spherically to support the atmospheric pressure load in tension. These units are supported by columns at each corner. The total load on each side of the fan structure is $2.8 \times 10^{8} \mathrm{~kg}$. The total gross electricity generation of the plant is 750 MWe. Of this, 580 MWe is used as follows: injector power supply, $560 \mathrm{MW}$; auxiliary systems, $20 \mathrm{MW}$. The net plant output is thus 
170 MWe, produced from a nuclear energy release of 640 MWt. The net plant efficiency is $27 \%$. A power flow diagram for this power plant is shown in Figure 94 . The waste heat system has not been designed.

Spent Plasma Collection for the LLL Mirror Design - The collection of partially burned fuel escaping from the plasma takes place in the direct convertor. Vacuum pumps in the direct convertor collect about $0.8 \mathrm{~kg} /$ day of tritium, $0.9 \mathrm{~kg} /$ day of deuterium, and $0.1 \mathrm{~kg} /$ day of helium. Escaping plasma particles are guided by magnetic fields into a large fan-shaped collector structure where the ions are captured and neutralized by collector electrodes. Following neutralization they are re-emitted as neutral gas atoms for collection by vacuum pumps.

The required gas throughput of $6.1 \times 10^{21}$ particles per second is achieved by four hundred 48 inch diffusion pumps, each having a capacity of $1.4 \times 10^{5} \mathrm{l} / \mathrm{sec}$. These pumps, having a combined pumping speed of $5.6 \times 10^{7} \mathrm{l} / \mathrm{sec}$, maintain a pressure of $2 \times 10^{-5}$ torr in the direct convertor. They consume 14 MWe of power during operation. Exclusive use of diffusion pumps is specified for three reasons: a diffusion pump system will have a lower tritium holdup; it is expected to be simpler and easier to maintain; and tritium recover/recycle costs are expected to be lower.

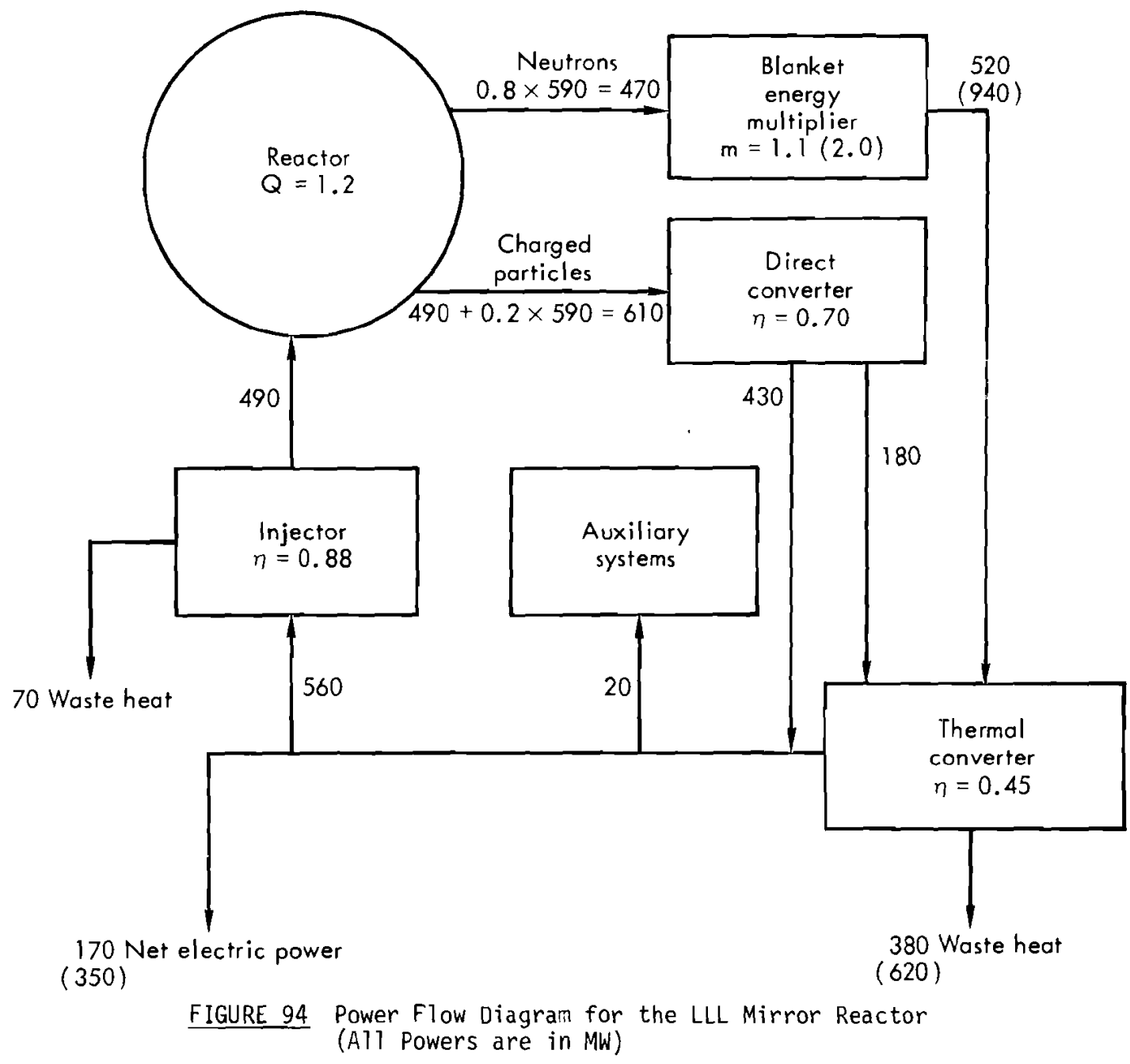


Bred Tritium Recovery for the LLL Mirror Design - The breeding ratio of tritium in the blanket lithium is between 1.0 and 1.2 , yielding about $0.09 \mathrm{~kg} /$ day of bred tritium. This tritium permeates through the walls of the stainless steel tubes, which contain the blanket lithium, into the evacuated interior of the reactor. It is then recovered by the vacuum system, and sent to the fuel system.

Heat transfer surfaces are coated with a refractory oxide such as alumina to inhibit permeation of the tritium into the helium intermediate coolant. As a result of this coating, it is estimated that only $0.033 \mathrm{~g} / \mathrm{yr}$ of tritium permeates into the helium. No system is provided to recover this tritium from the helium intermediate coolant.

The tritium concentration or inventory expected in the blanket lithium has not been estimated. Tritium permeation from the blanket lithium is expected to depend on the diffusion of tritium in the lithium itself due to laminar flow caused by magnetic fields. Diffusion rates cannot be calculated without information on this process. Tritium flows in the plant are indicated in Figure 95. Tritium inventories have not been estimated for the systems handing these tritium flows.

Containment Building for the LLL Mirror Design - The massive evacuated spherical structure that supports the forces acting on the magnet coils and the evacuated structure of the direct convertor expander/collector fan provide containment for this reactor. Detailed designs have not been prepared.

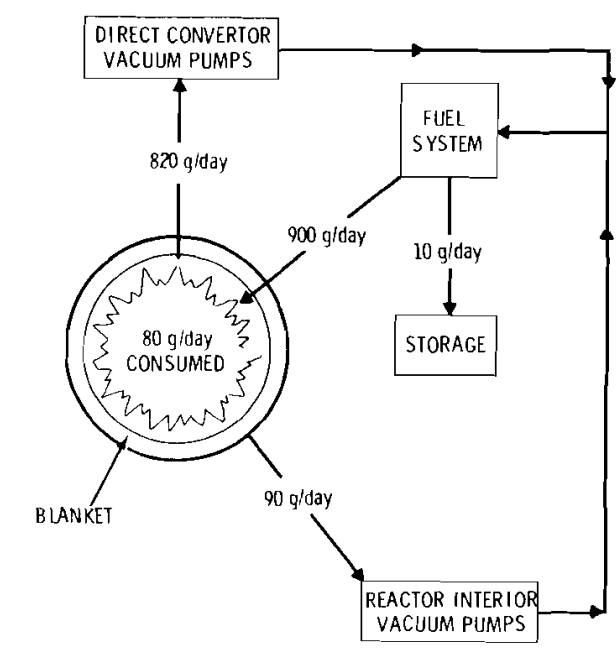

FIGURE 95 Tritium Flows in the LLL Mirror Power Plant 


\subsection{Inertial Confinement}

The inertial confinement concept is based upon the possibilities that a pellet of D-T fuel can be imploded and heated to thermonuclear ignition conditions by focused laser or electron beams; and that before the pellet can be blown apart by the resulting fusion microexplosion sufficient fusion energy can be released to generate electricity to operate the laser with excess for export. In proposed power plant concepts, fuel pellets are projected into the central cavity of a reactor chamber, where they are ignited by laser beams. Blast effects of the microexplosions are confined by the reactor chamber, and the fusion energy released is captured in a blanket surrounding the central cavity. Tritium is also bred in the blanket, by neutron reactions with lithium. Roughly three quarters of the fusion energy is delivered to the blanket by neutrons, and is distributed over the volume of the blanket. The remainder, however, is delivered to the surface of the reactor chamber as the kinetic energy of pellet debris and helium "ash," and as x-rays. Because this energy is deposited very rapidly, very close to the surface, structural surfaces must be protected. Protection concepts proposed include surface layers of ablative materials, and the use of magnetic fields to confine and direct microexplosion plasma into special collection geometries. The power plant designs described in this section all use an initial surface of liquid lithium to receive the direct microexplosion effects. Surface geometries and the aftereffects of ablation differ considerably between the designs, however.

Megajoule amounts of energy are released in pellet microexplosions, and one may note that the energy release of chemical high explosive is about 2 MJ per pound of TNT. However, the blast effect of a fusion pulse will be much smaller than that of a TNT explosion for two reasons. First, the mass of debris carrying the blast is a million times smaller than the mass of debris from an equivalent TNT explosion; and second, most of the energy is carried by neutrons which penetrate material surfaces and interact with a distributed volume of material. Consequently, blast effects of fusion pulses will be more than 1000 times weaker than blast effects of TNT explosions of equivalent energy. Nevertheless, the complexity of confinement analysis may be indicated by noting that ablative blowoff from chamber surfaces can cause shock waves which amplify blast effects by orders of magnitude.

\subsubsection{ORNL Blascon}

Summary Description - The ORNL Blascon laser-fusion power plant $(10,14,15)$ produces an average thermal energy release of 4800 MWt; gross plant electrical generation is 1920 MWe. Net plant electrical output is not specified. The power fraction which must be recirculated to power the lasers and other plant equipment is not known. The plant consists of 12 reactor chambers, in each of which pellet microexplosions occur at the rate of one every 2 seconds. Continuous electrical generation is possible even though the thermonuclear burn cycle is pulsed, due to the heat capacity of the reactor materials. Overall plant layout is indicated in Figure 96.

The reactor chambers contain liquid lithium metal, which functions as a coolant, neutron moderator, and a fertile material to breed tritium fuel. This primary coolant exchanges heat to 


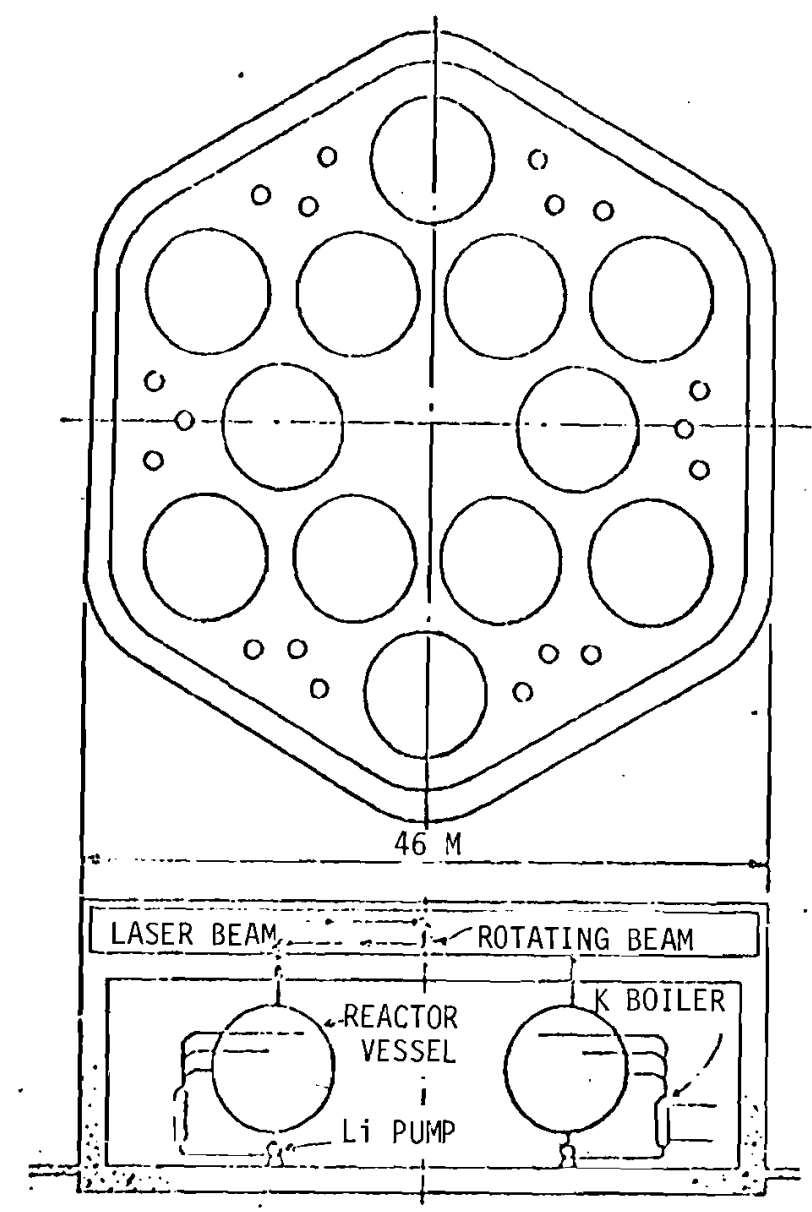

FIGURE 96 ORNL Blascon Power Plant Layout

low-radioactive NaK intermediate coolant (a sodium-potassium liquid metal mixture) that transports it to steam generators. Steam at $450^{\circ} \mathrm{C}$ is used to drive the turbine generators.

Major power plant systems are identified and their functional relations are indicated in Figure 97. The reactor is located inside of the containment building (Figure 96). Sealed rooms are specified for tritium recovery equipment. The individual reactor chambers are spherical, having an outer diameter of $8.2 \mathrm{~m}$. The structural material is stainless steel.

The reactor chambers confine the laser-pellet microexplosions, each of which releases $800 \mathrm{MJ}$ of energy. They consist of a pressure vessel containing a swirling pool of molten lithium. A vertical vortex created by the swirling lithium forms a central cavity and the free lithium vortex surface serves as the inner wall of the chamber. Pressure pulses due to the microexplosions are cushioned by inert gas bubbles entrained in the lithium and are absorbed by the outer pressure vessel. Vortex dimensions are chosen to minimize the amount of lithium ablated from the vortex surface, thus minimizing the strength of the pressure pulses to be absorbed. A chamber is shown in Figure 98.

Heating of the fuel pellets to ignite the thermonuclear burn is accomplished by a single laser facility. The reactor chambers are arranged around a central rotating mirror system which 


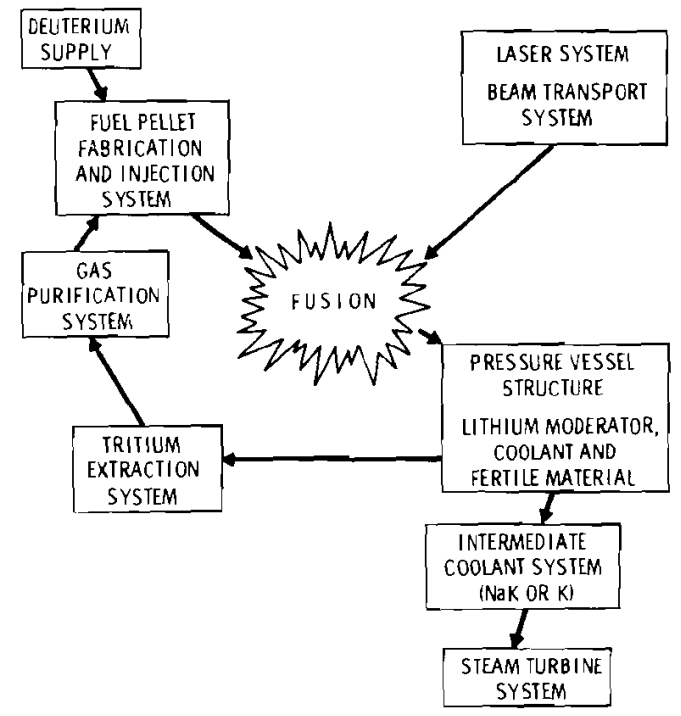

FIGURE 97 Functional Relations Between Systems of the ORNL Blascon Laser-Pellet Power Plant

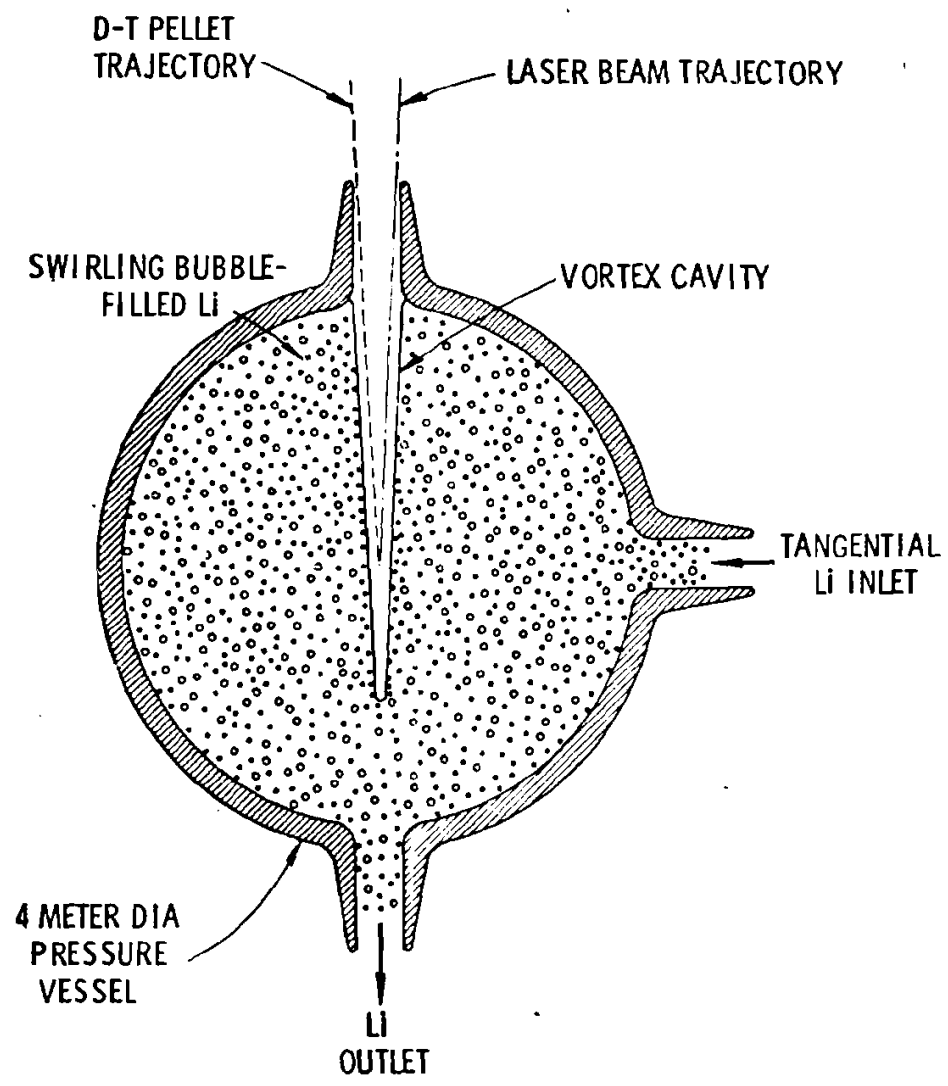

FIGURE 98 Cross Section of the ORNL Blascon Pressure Vessel and Lithium Vortex 
transmits a single laser pulse to each of the chambers in turn. Symmetrical fuel pellet irradiation by a single laser beam is achieved by mounting the pellet at the focus of a (solid) lithium mirror which is pneumatically injected into the vortex cavity along with the pellet. The laser facility delivers $1.0 \mathrm{MJ}$ of energy to each pellet, pulsing 6 times per second to serve the 12 reactor chambers.

At $100 \%$ load factor, the system of 12 reactor chambers requires $5.2 \times 10^{5}$ pellets/day. A fuel consumption rate of about $0.6 \mathrm{~kg} /$ day of tritium and $0.4 \mathrm{~kg} /$ day of deuterium is required. Unburned fuel not absorbed by the lithium is collected by reactor chamber vacuum pumps for recycle.

Energy collection and tritium breeding take place in the lithium contained in the reactor chamber. The central vortex has a radius of about $44 \mathrm{~cm}$. It is followed by $356 \mathrm{~cm}$ of lithium containing a $3 \%$ void fraction of bubbles, and the $10 \mathrm{~cm}$ thick pressure vesse 1.

Twelve independent lithium/NaK/steam coolant loops, one for each reactor chamber, transmit heat energy to the turbine generators. Reactor chamber temperatures are 1 imited due to the use of stainless steel structure with lithium coolant. Hot leg temperatures in the lithium, NaK and steam loops are $500^{\circ} \mathrm{C}, 475^{\circ} \mathrm{C}$ and $450^{\circ} \mathrm{C}$.

Electricity is generated by conventional steam turbine-generator units at a gross thermal efficiency of $40 \%$.

Following the fusion microexplosions, spent fuel is primarily entrained and dissolved in the 1 ithium within the reactor chamber. About $0.8 \mathrm{~kg} /$ day of tritium is bred in the lithium at a breeding ratio of 1.3 . Bred and absorbed tritium is allowed to permeate into the NaK intermediate coolant, and is recovered from a cold-leg side stream. A few percent of liquid lithium is dissolved in the NaK and getters the tritium. The resulting lithium tritide is then collected in filtered cold traps. Tritium inventories for plant systems have not been determined.

Plasma Confinement System for the ORNL Blascon Power Plant - After an inertially confined microexplosion, the hot plasma expands rapidly and impacts the surface of the reactor chamber which confines it. About $25 \%$ of the energy from each $800 \mathrm{MJ}$ microexplosion is deposited on the reactor chamber surface, which is the free surface of a vertical vortex in a swirling pool of liquid lithium. The swirling lithium is driven by injecting lithium into the reactor chamber through three tangential nozzles in the perimeter of the vessel. Lithium removal through a central port in the bottom of the chamber stabilizes the vortex. Ports are indicated in Figure 98.

Pressure pulses are caused in the lithium by the microexplosion debris and by lithium ablation from the vortex surface. These shock waves are cushioned by inert gas bubbles injected into the lithium. These bubbles occupy about $3 \%$ of the lithium volume but cushion lithium volume changes due to thermal expansion as well as shock waves from surface effects.

Shock wave attenuation by a factor of 10 is expected due to the presence of bubbles entrained in the 1 ithium. Mechanisms thought to cause attenuation are bubble compression, shock wave dispersion by curved bubbie surfaces, and material spallation from bubble surfaces. Pressure puises 
due to the fusion microexplosions are absorbed by an outer pressure vessel $10 \mathrm{~cm}$ thick. It is expected that shock wave stresses on this vessel will not exceed stresses due to the static pressure of the liquid lithium.

Plasma Heating System for the ORNL Blascon Design - A single laser system irradiates each fue1 pellet, in each reactor chamber, with a single laser beam which delivers $1.0 \mathrm{MJ}$ of energy. Fixed and rotating mirrors (Figure 96 ) direct the laser beam to each chamber in succession. Laser type, wavelength, and efficiency has not been determined.

Uniform illumination of each fuel pellet by a single laser pulse is achieved by mounting each pellet at the focus of a small parabolic mirror made of frozen lithium. The pellet and mirror arrangement is shown in Figure 99. Frozen lithium is chosen for the mirror so that it will not contaminate the system.

The laser beam width is 2.5 times the diameter of the pellet so that light in the outer portion of the beam reflected back against the sides and bottom of the pellet gives a uniform energy input over the entire pellet surface. The various elements of the laser amplifier system are timed so that light in the center of the beam is retarded slightly with respect to that in the outer portion of the beam; simultaneous illumination of the top and bottom of the pellet is achieved, despite differences in path length.

The laser system cannot be isolated from the reactor chamber injection port by a window due to the high intensity of the laser pulses. Consequently, it is coupled to the reactor injection port by an enclosed housing in which an inert gas atmosphere of a few torr pressure is maintained. cooling of metallic mirrors in the path of the laser beam will be difficult. Silver mirrors, with the best reflecting surface obtainable, absorb about $1 \%$ of the beam energy as heat. Such mirrors, reflecting $10^{6} \mathrm{MJ}$ laser pulses every 2 seconds, receive a heat flux of $64 \mathrm{~W} / \mathrm{cm}^{2}$. This

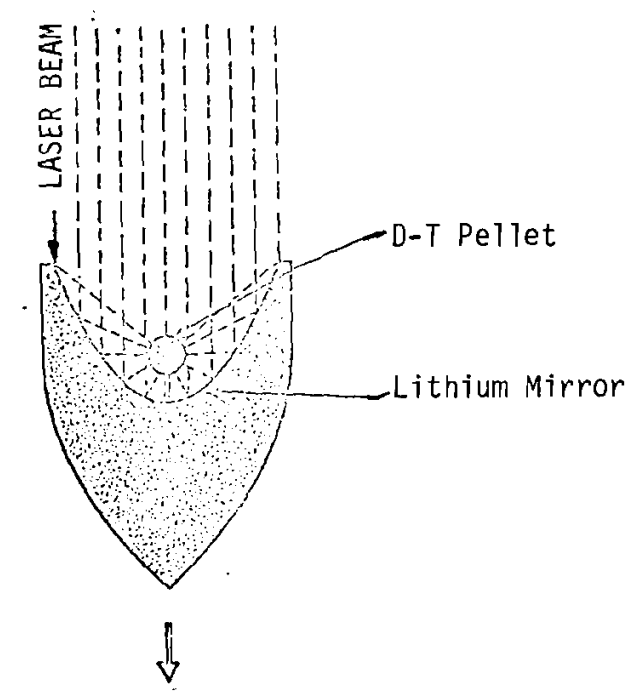

FIGURE 99 Conceptual Blascon Fuel Pellet/Mirror Assembly 
is close to the upper limit for water cooling, and the resulting thermal gradients are likely to induce thermal strains producing distortion of the optical surface.

Fuel System for the ORNL Blascon Design - The size and burnup fraction of the frozen deuteriumtritium fuel pellets have not been determined. At 100\% 1oad factor, the system of 12 reactor chambers requires $5.2 \times 10^{5}$ pellets/day. A fuel consumption rate of about $0.6 \mathrm{~kg} /$ day of tritium and $0.4 \mathrm{~kg} /$ day of deuterium is required for the specified plant thermal power level. The fuel system functions to purify recycled fuel and bred tritium recovered from the blanket, to prepare it in pellet form, and to inject it. The purification process for recycled fuel and bred tritium has not been designed.

Each fuel pellet is mounted at the focus of a parabolic lithium mirror. The pellet/mirror assembly is pneumatically injected into the reactor chamber by an inert gas gun. Its trajectory into the vortex cavity is indicated in Figure 98. The assemblies are injected at a velocity of about $100 \mathrm{~m}$ per second to minimize evaporation from the pellet surface during $i$ ts passage into the center of the vortex cavity. Photocells are used to track the assembly so that the laser can be triggered at the proper instant.

The opening into the reactor chamber is equipped with a muffler arrangement to reduce blowback. The muffler, illustrated in Figure 100, consists of a retractable plug with a system of baffles. The baffle system, in conjunction with the long neck of the injection port, acts to break the normal shock wave up into a number of oblique waves and thus dissipates much of its energy. Blanket for the ORNL Blascon Reactor - In addition to confining the fusion microexplosions, the blanket surrounding the central cavity of each of the 12 reactor chambers must convert neutron energy to heat, breed tritium, and provide for the removal of heat.

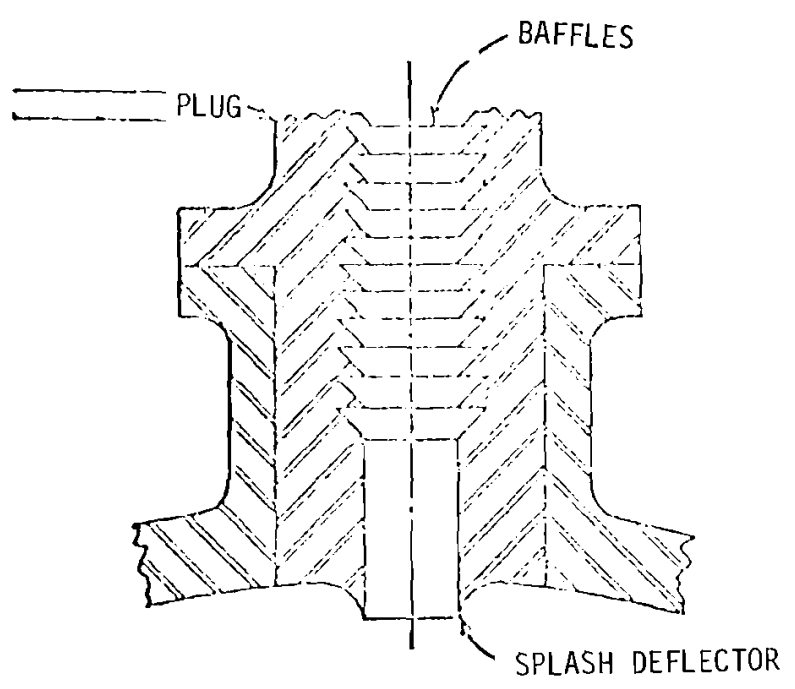

FIGURE 100 Muffler System of the Blascon Design 
The Blascon blanket consists entirely of liquid lithium metal which acts as primary coolant, neutron moderator and fertile material for the breeding of tritium. The reactor chamber central cavity is a vertical vortex, of radius $44 \mathrm{~cm}$ (Figure 98). This is followed by $356 \mathrm{~cm}$ of lithium containing a $3 \%$ void fraction of inert gas bubbles. The lithium inventory per reactor chamber is 1603 metric tons. The lithium is contained within a $10 \mathrm{~cm}$ thick pressure vessel having an outer diameter of $8.2 \mathrm{~m}$. This pressure vessel absorbs the pressure pulses produced by the fusion microexplosions.

The liquid lithium enters the chambers through three tangential nozzles in the vessel perimeter, and exits through a central bottom port (Figure 98 ). The vortex size is chosen so that no appreciable amount of lithium is ablated from the surface by the microexplosions. Consequently, the energy release simply raises the temperature of the lithium, with the greatest heating near the vortex surface. Radial dispersion of heat is achieved by turbulent mixing between fluid layers in the vortex. Lithium temperature equilibration within about 1 second is expected which is the basis for choice of the 2 second interval between microexplosions.

Neutron damage to the reactor chamber is minimized in this design by eliminating the chamber inner wa11. No estimate has been made of chamber lifetime limitations due to radiation damage or fatigue.

Heat Transfer System for the ORNL Blascon Design - Liquid lithium, the primary coolant, carries heat that it absorbs in the reactor chambers to external heat exchangers where it is traisferred to an intermediate coolant which is a mixture of liquid sodium and potassium, called NaK. This intermediate coolant transfers the heat to steam generators where it is used to raise steam to drive the turbine-generators (Figure 101). Twelve independent lithium/NaK/steam coolant loops are used, one for each reactor chamber.

The lithium primary coolant also functions as a neutron moderator and a fertile material for tritium breeding. Consequently, significant quantities are contained within the reactor chambers

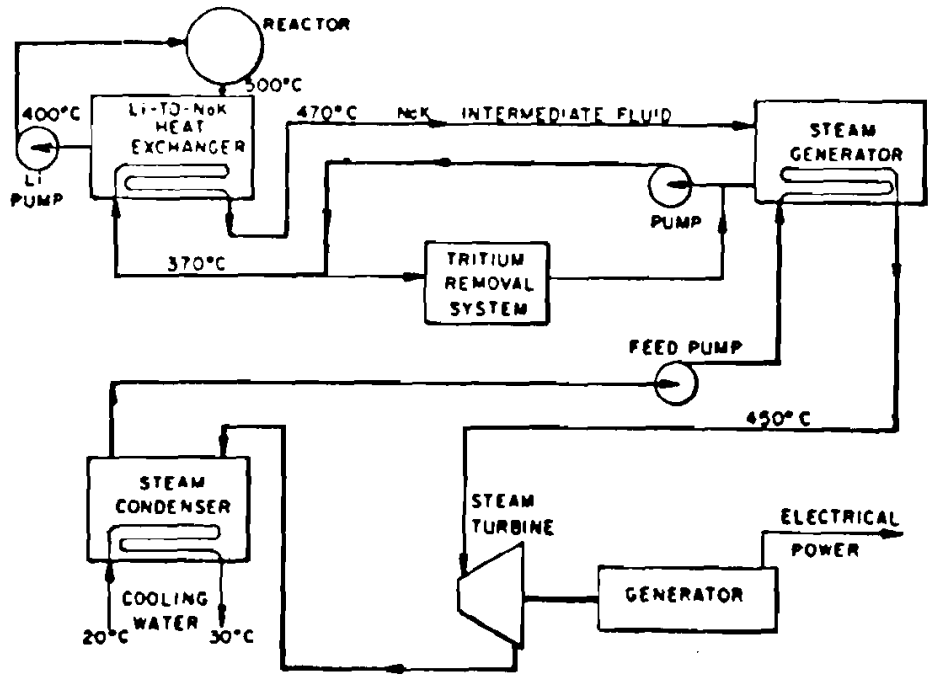

FIGURE 101 Flow Sheet for the Blascon Steam System 
as well as in the primary coolant system. Plant lithium inventory is $1.6 \times 10^{6} \mathrm{~kg}$. The total plant lithium circulation rate is $4.2 \times 10^{7} \mathrm{~kg} / \mathrm{hr}$, requiring 17 MWe of pumping power. The $1 \mathrm{ith}-$ ium coolant enters the blanket at $400^{\circ} \mathrm{C}$ and exits at $500^{\circ} \mathrm{C}$. The lithium temperature increase is limited to $100^{\circ} \mathrm{C}$ by thermal stresses in the pressure vessel.

Heat exchange from the lithium to NaK intermediate coolant takes place in stainless steel intermediate heat exchangers having a total'surface area of $9.4 \times 10^{3} \mathrm{~m}^{2}$. NaK enters the heat exchangers at $370^{\circ} \mathrm{C}$ and exits at $470^{\circ} \mathrm{C}$. Pressures and flow rates of the NaK coolant have not been determined. The intermediate heat exchangers will be located in shielded compartments due to radioactivity in the lithium coolant.

Steam at $450^{\circ} \mathrm{C}$ is generated by the NaK intermediate coolant in steam generators constructed of stainless steel. The total surface area of the steam generators is $1.5 \times 10^{4} \mathrm{~m}^{2}$. Their design is based upon LMFBR technology.

Electricity Generation System in the ORNL Blascon Power Plant - Electricity is generated by conventional steam turbine-generators. Gross plant electrical generation is 1920 Mwe, produced from 4800 MWt at a thermal efficiency of $40 \%$. The fraction which is used within the plant by lasers and other plant equipment is not known.

The waste heat dissipation system has not been designed.

Spent Plasma Collection System for the ORNL Blascon - Following each fusion microexplosion, pellet debris, unburned fuel, and radiation impact the free surface of the lithium vortex, ablating only a small amount of lithium vapor. Since the fuel pellet size has not been determined the plant production rate of spent plasma is unknown. However, a total helium production rate will be about $0.8 \mathrm{~kg} /$ day.

Noncondensables including helium, unburned fuel not absorbed in the liquid lithium, and inert gas used to purge the chamber inlet port are drawn off in a vacuum system. This vacuum system will maintain a pressure of a few torr in the port and vortex regions of each reactor chamber; however, it has not been designed. The systems for recovering and reusing tritium have not been designed.

Unburned fuel which is absorbed in the lithium blankets of the reactor chambers is recovered along with tritium bred therein.

Bred Tritium Recovery System for the ORNL Blascon Reactor - The breeding ratio of tritium in the blanket lithium is 1.3 . About $0.8 \mathrm{~kg} /$ day of tritium is bred and is allowed to permeate into the NaK intermediate coolant through the stainless steel tubes of the intermediate heat exchanger. It is recovered from the NaK by a liquid gettering arrangement. A few percent of liquid lithium is mixed into the NaK and it absorbs the tritium preferentially. The resulting LiT is then crystaliized and collected in filtered cold traps operating in a cold-leg side stream of the intermediate coolant loop. Tritium inventories for plant systems have not been determined. Tritium flows in the plant are indicated in Figure 102. 


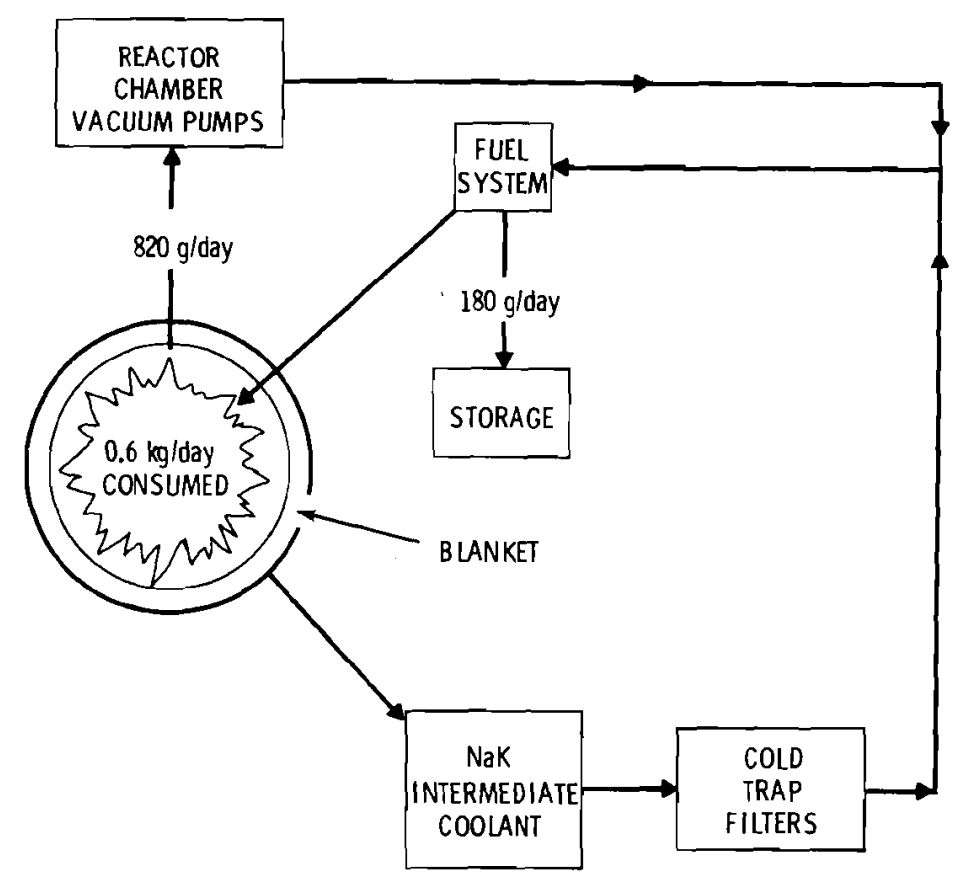

FIGURE 102 Tritium Flow Schematic for Blascon

Containment Building for the ORNL Blascon Reactor - Containment is provided by the reactor building shown in Figure 96. Shielded compartments will be provided to enclose primary coolant piping and sealed rooms will enclose tritium recovery equipment.

\subsubsection{Los Alamos Wetted Wall}

Summary Description - The LASL Wetted-Wall laser-fusion power plant $(11,16,17)$ produces 1000 MWe of net electrical power from an average thermal energy release of $3745 \mathrm{MWt}$. The plant consists of 24 reactor chambers in each of which pellet microexplosions occur at a rate of 1.7 per second. Continuous electrical generation is possible even though the thermonuclear burn cycle is pulsed, due to the heat capacity of reactor materials. Overall plant layout is indicated in Figure 103.

The reactor chambers are cooled by liquid lithium metal which also functions as a neutron moderator and a fertile material to breed tritium fuel. This primary coolant exchanges heat to a low-radioactive sodium intermediate coolant which is used to generate steam to drive turbine-generators.

Major power plant systems are identified and their functional relations are indicated in Figure 104. The reactor is located in a containment building which provides two levels of containment. Primary containment is provided by the concrete cell in which the reactor is located. Secondary containment is provided by the building itself which encloses the reactor chambers, the laser amplifiers and optics, coolant piping and processing equipment, and fuel system facilities.

The individual reactor chambers are spherical, having outer and inner diameters of 5.8 and $3.4 \mathrm{~m}$. They are constructed primarily of stainless steel. The reactor chambers confine the laser-pellet 


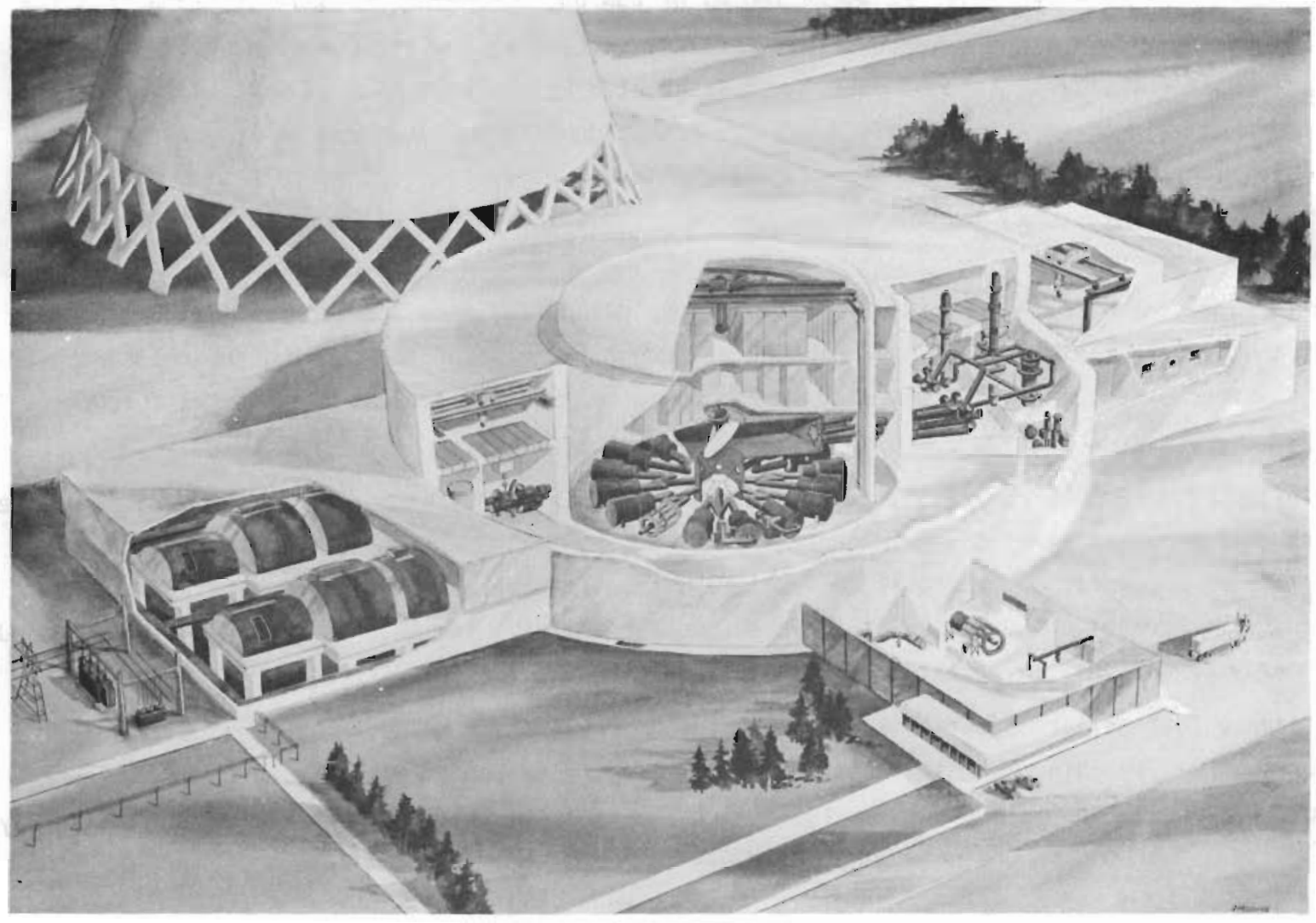

FIGURE 103 Overa11 Plant Layout of the LASL Conceptual Laser-Fusion Power Plant

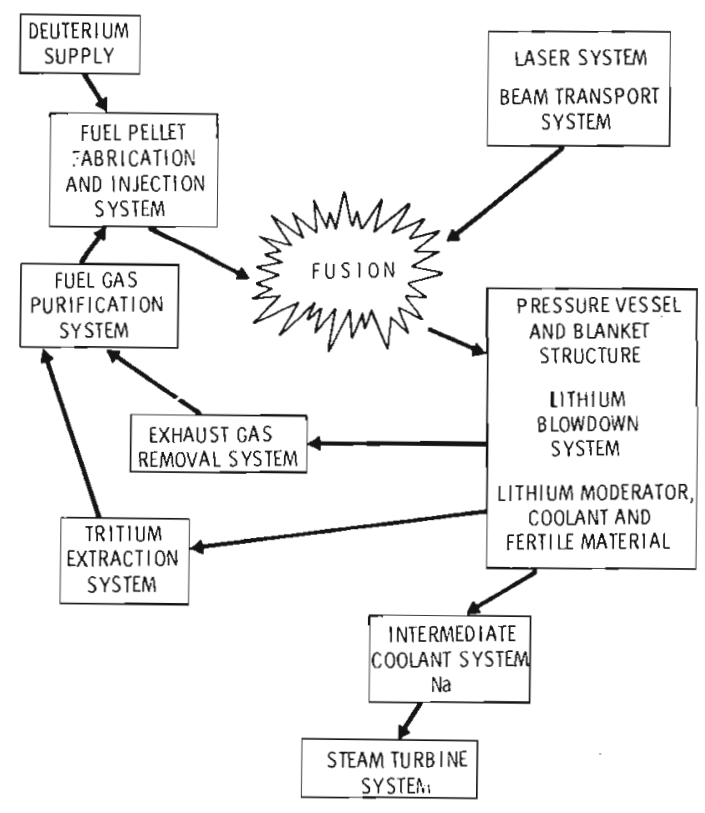

FIGURE 104 Functional Relations Between Systems of the LASL Wetted Wa11 Laser-Pellet Power Plant 
microexplosions, each of which releases $100 \mathrm{MJ}$ of energy. The concept takes its name from the thin layer of liquid lithium which forms a protective coating for the porous niobium inner wall of the reactor chamber. Some of this layer is ablated by the high flux of particles and radiation emanating from each microexplosion. The resulting lithium vapor and pellet debris then blow down through a supersonic spray condenser shown in Figure 105. The protective lithium layer is then restored by inflow through the porous niobium inner wall from the 1 ithium blanket surrounding the cavity.

Pressure pulses resulting from the fusion microexplosions and from the rapid ablation of lithium from the reactor chamber inner wall propagate through the blanket surrounding the chamber. They are absorbed by a thick stainless steel pressure vessel located deep in the blanket (Figure 105). Heating of the fuel pellets to ignite the thermonuclear burn is accomplished by a single laser facility. The reactor cavities are arranged in a circular array around a central optical device which employs a system of fixed and rotating mirrors to transmit laser pulses to each of the reactors in sequence. Symmetrical pellet irradiation is achieved by simultaneously focusing laser beams from eight $\mathrm{CO}_{2}$ laser amplifiers upon the pellet. The laser facility delivers $1.0 \mathrm{MJ}$ of energy to each pellet, pulsing 29 times per second to serve the 24 reactor chambers.

A separate fuel pellet injection system serves each reactor chamber. The pellets are frozen spheres of D-T weighing 1.3 milligrams. At 100\% load factor, the system of 24 reactor chambers requires $2.5 \times 10^{6}$ pellets/day. The fuel injection rate is $1.9 \mathrm{~kg} /$ day of tritium and $1.3 \mathrm{~kg} /$ day

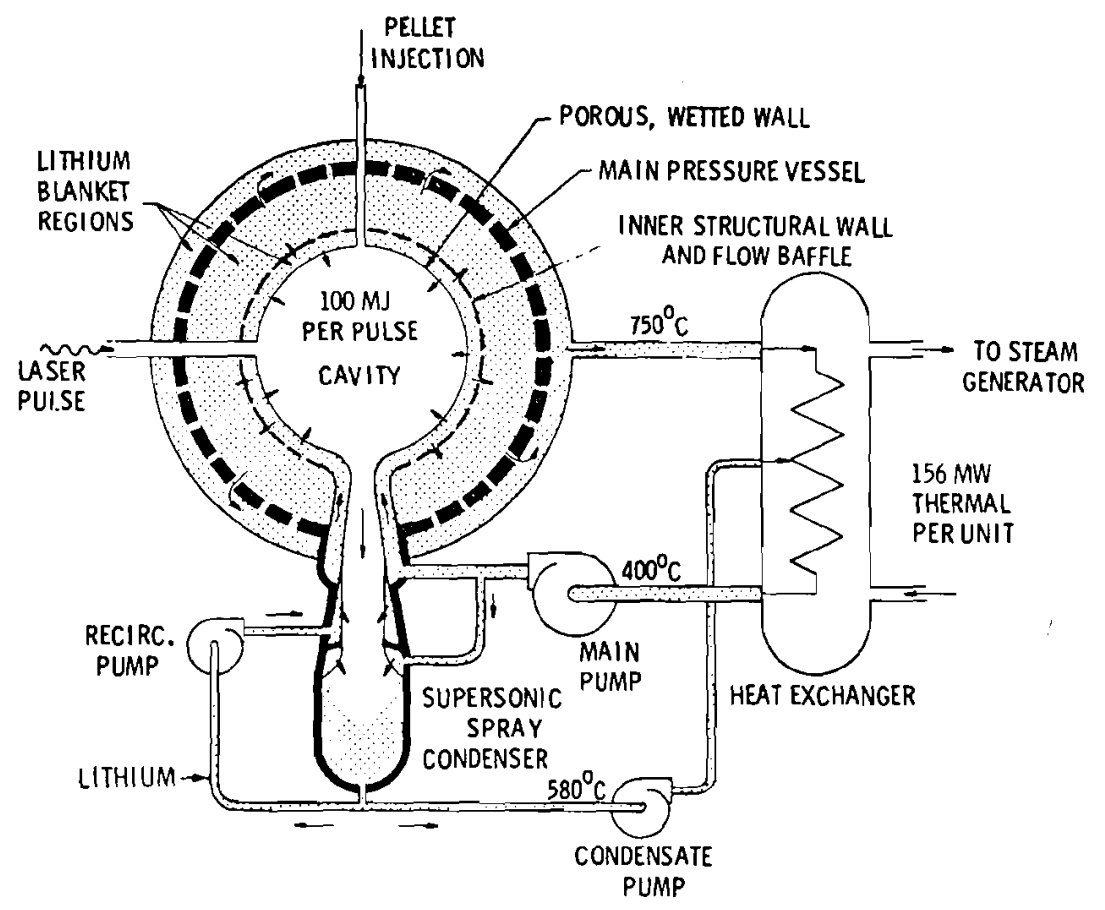

FIGURE 105 Cross Section and Flow Schematic of the LASL Wetted Wall Laser-Pellet Design 
of deuterium. Pellet burnup is $22 \%$, yielding a fuel consumption rate of $0.43 \mathrm{~kg} /$ day of tritium and $0.28 \mathrm{~kg} /$ day of deuterium. Unburned fuel is recovered from the blowdown system, purified, and recycled.

Energy collection and tritium breeding take place in the $1.2 \mathrm{~m}$ thick blanket surrounding the reactor chamber. This blanket, illustrated in Figure 105, consists primarily of 1ithium. Within the lithium are located a $5 \mathrm{~cm}$ thick structural wall and a $10 \mathrm{~cm}$ thick pressure vessel, both made of stainless steel. Total lithium thickness is $1.0 \mathrm{~m}$.

Twelve independent 1 ithium/sodium/steam coolant loops, one for each pair of adjacent reactor chambers, transmit heat energy to the turbine-generators. The blanket outlet temperature of the lithium primary coolant is $550^{\circ} \mathrm{C}$. Temperatures have not been determined for the sodium and steam systems. LMFBR technology will be used. Electricity generation is by conventional steam turbine-generator units at a thermal efficiency of $40 \%$. The net plant efficiency is $27 \%$.

Following the fusion microexplosions, spent fuel blows down with the ablated lithium vapor at the rate of $1.5 \mathrm{~kg} /$ day of tritium, $1.0 \mathrm{~kg} /$ day of deuterium and $0.58 \mathrm{~kg} /$ day of helium (total plant). A fraction is entrained and absorbed by the lithium in the spray condensors; the remainder is collected by vacuum pumps for return to the fuel system. Lithium tritide formed in the condensers and condensable materials from the pellets is recovered from a side stream of the condensor flow in filtered cold traps.

About $0.5 \mathrm{~kg} /$ day of tritium is bred in the lithium coolant/fertile material at a breeding ratio of 1.2. The recovery method has not been determined. Possibilities are tritium diffusion through a niobium membrane at high temperatures, and recovery of crystallized lithium tritide in filtered cold traps. Tritium inventories for plant systems have not been determined.

Plasma Confinement System for the LASL Laser-Fusion Reactor - After an inertially confined microexplosion, the hot plasma expands rapidly and impacts the surface of the reactor chamber which confines it. About 23\% of each $100 \mathrm{MJ}$ microexplosion is deposited on the reactor chamber surface. This surface consists of a $1 \mathrm{~mm}$ thick ablative layer of liquid lithium on a porous niobium wall $1 \mathrm{~cm}$ thick. Deposition of this energy in 100 nanoseconds yields a surface energy deposition rate of $7.5 \times 10^{8} \mathrm{~J} / \mathrm{cm}^{2}-\mathrm{sec}$. This is expected to result in the ablation of kilogram amounts of lithium by each microexplosion. The resulting lithium vapor is blown down through a spray condenser into a pool of liquid lithium along with pellet debris and unburned fuel. Details of the supersonic diffuser/condenser are shown in Figure 106. The lithium layer on the reactor chamber surface is restored after each pulse by inflow from the blanket 1 ithium through the porous niobium wall.

The divergent duct area of the diffuser/condenser provides a supersonic nozzle into which the lithium vapor can expand. An atomized spray of liquid droplets is injected into the vapor stream to control condensation and a coarse liquid spray is injected to produce deceleration through turbulent mixing. The kinetic energy of the mixture is then absorbed by impacting in a stagnant pool of lithium of greater depth (greater gravitational head) than the kinetic head of the mixture. 


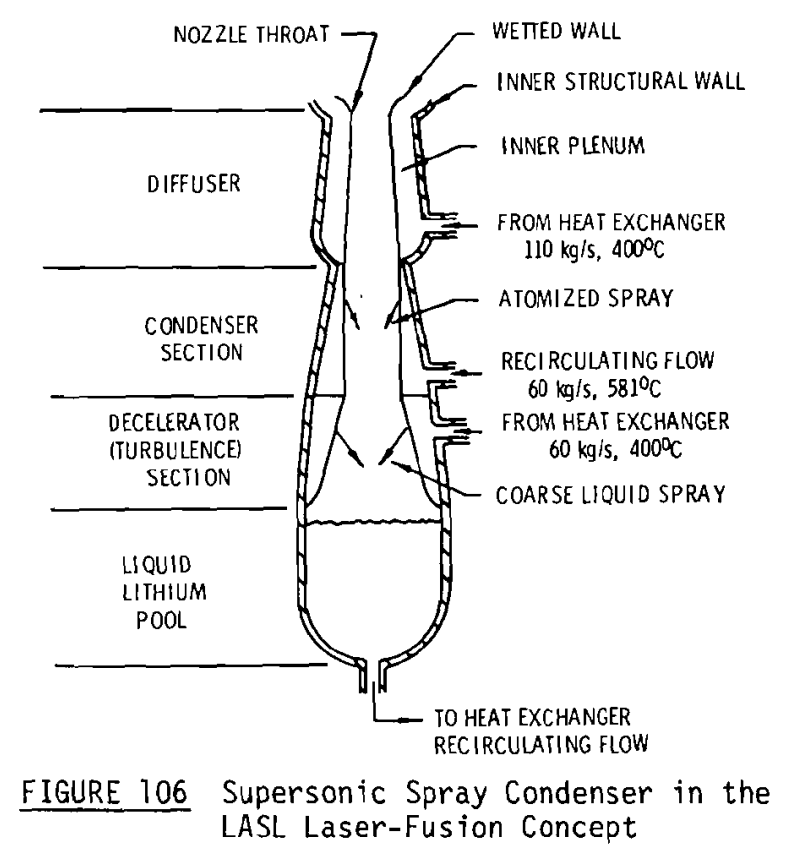

Pressure pulses produced by lithium ablation at the cavity wall and by neutron heating of the lithium blanket are absorbed by a $10 \mathrm{~cm}$ thick stainless steel pressure vessel located within the blanket (Figure 105).

Plasma Heating System for the LASL Laser-Fusion Reactor - A single, centrally located laser system, indicated in Figure 107, irradiates each fuel pellet in each reactor chamber with eight simultaneous laser beams which deliver a total of $1.0 \mathrm{MJ}$ of energy. This laser system utilizes a system of fixed and rotating mirrors to focus beams from eight $\mathrm{CO}_{2}$ laser amplifiers (wavelength $10.6 \mu \mathrm{m}$ ) on pellets in each of the 24 reactor chambers in turn. The laser system operates at $7 \%$ efficiency and requires 500 MWe of recirculated electrical power. A cross section through this laser system, showing a laser amplifier, the mirror system and an optical device to prevent radiation streaming down the beam tube is shown in Figure 108.

Symmetrical pe1let irradiation by the eight laser beams is achieved by arranging the beam transport tubes as shown in Figure 109.

The laser system operates with a repetition rate of 29 times per second, to serve the 24 reactor chambers. It delivers time-tailored laser pulses of 1 to 10 nanoseconds duration. This results in pellet compression to a density between 1 and 10,000 times the initial pellet density and ignition of the thermonuclear burn. The plant is provided with 8 pairs of laser power amplifiers (Figure 109). Total redundancy is provided to insure uninterrupted operation in the event of malfunction.

High power $\mathrm{CO}_{2}$ laser amplifiers require considerable cooling of the laser gas. A gas flow rate of about $400 \mathrm{~m} 3$ per second is needed for each amplifer in order to provide the required $52 \mathrm{MW}$ of cooling capacity. (17) 


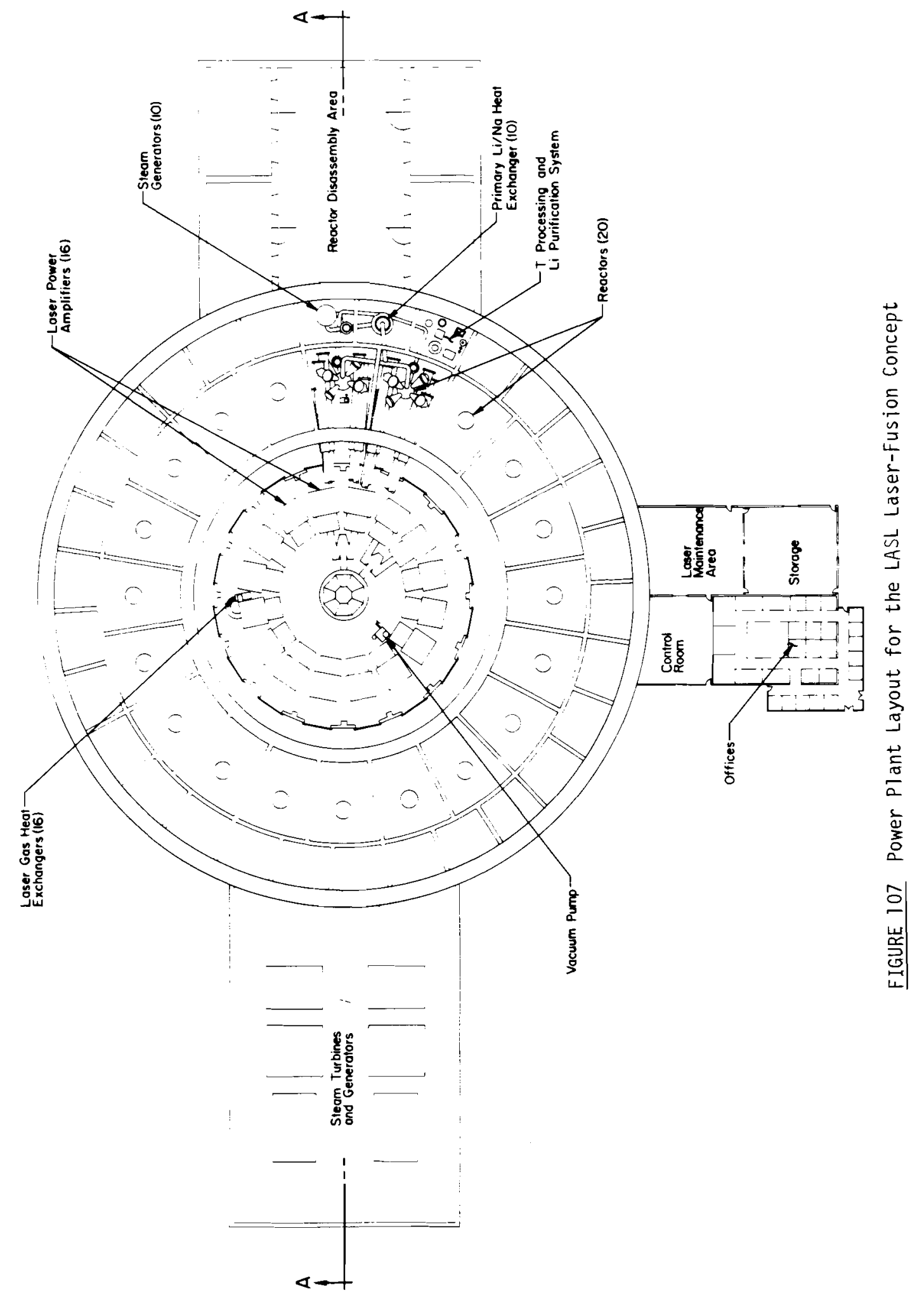




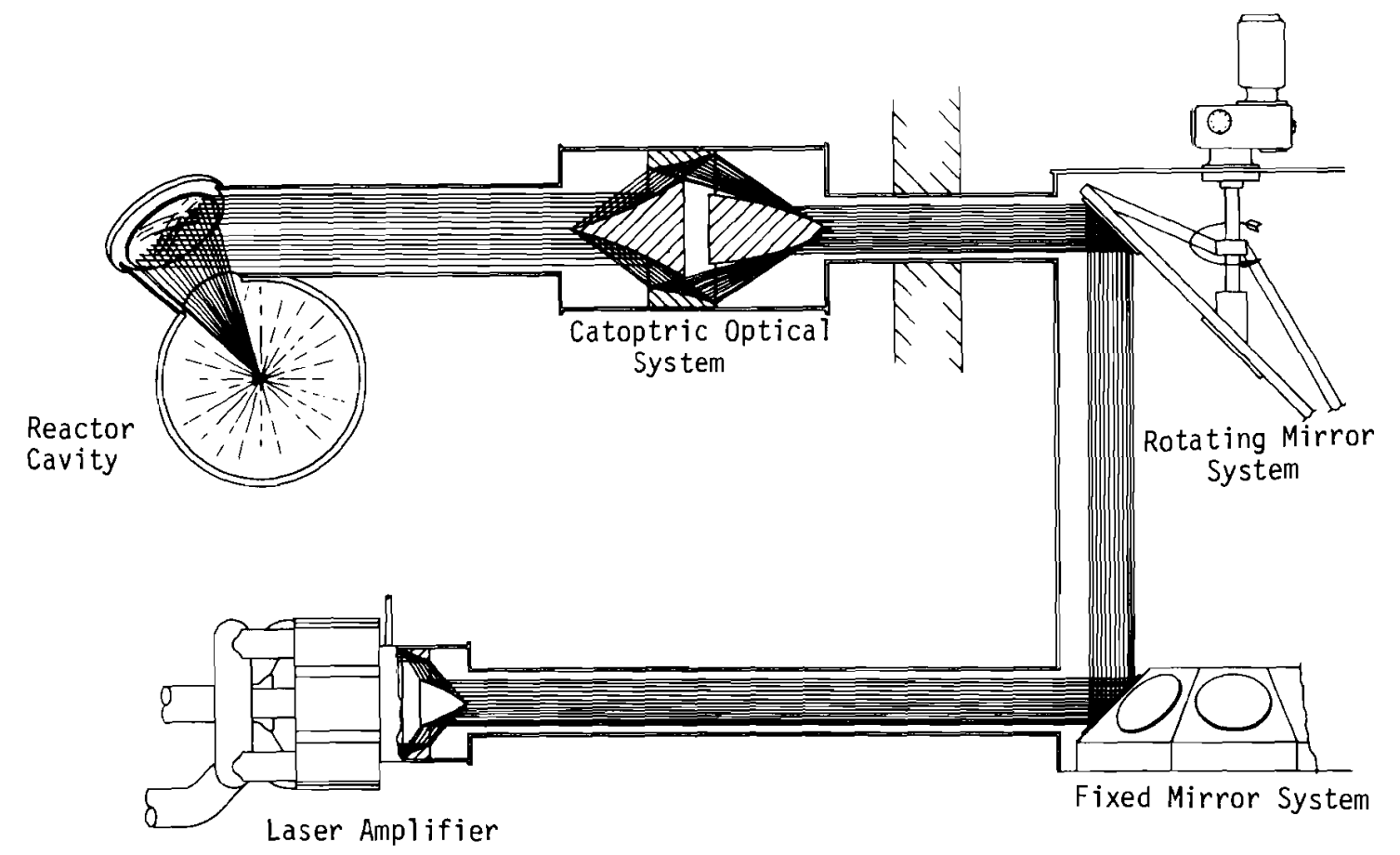

FIGURE 108 0ptical System for Delivery of Laser Pulse to LASL Laser-Fusion Reactor Cavity

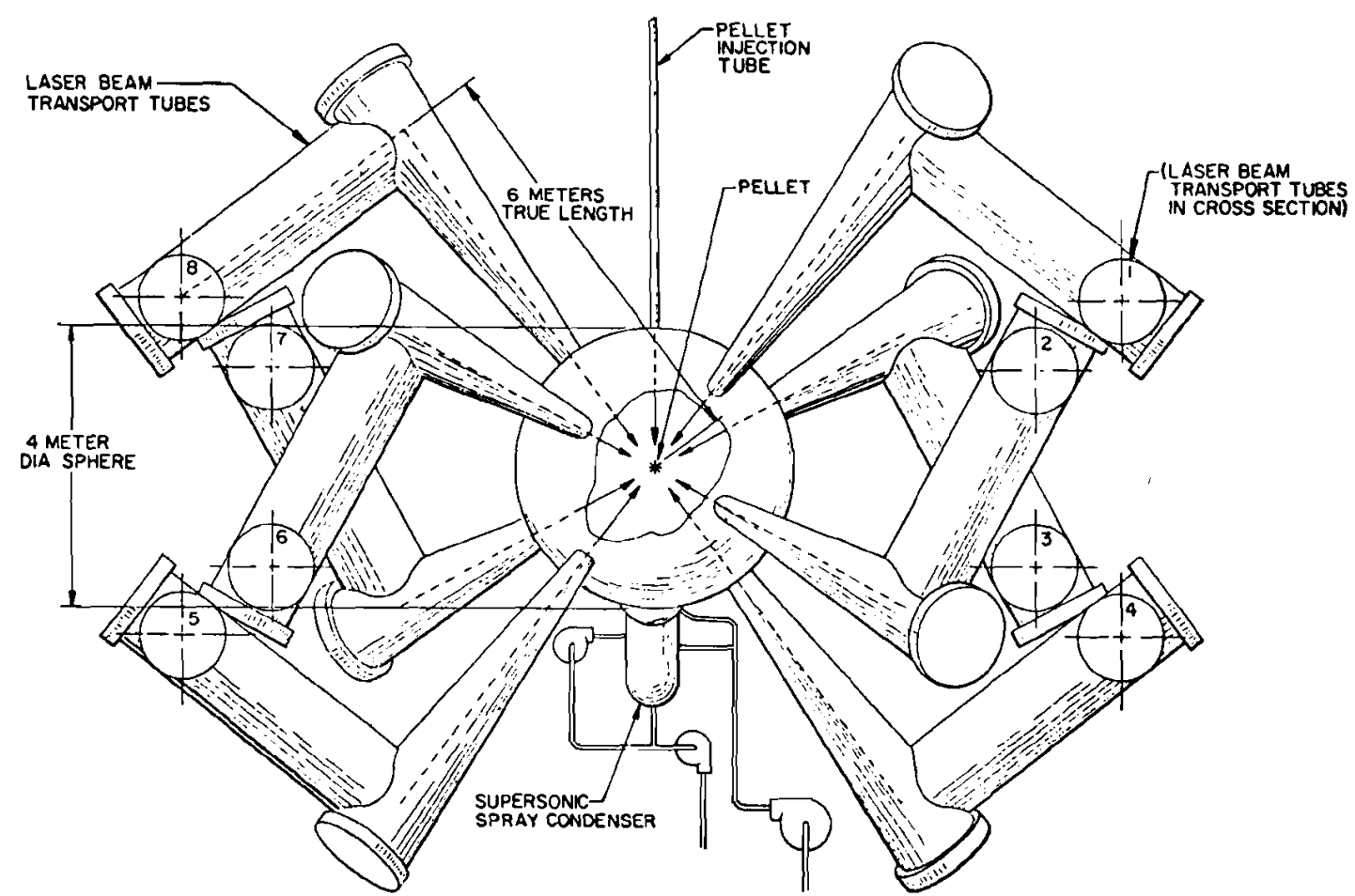

FIGURE 109 Laser Beam Tubes for Symmetrical Pellet Irradiation in the LASL Design 
Fuel System for the LASL Laser-Fusion Concept - A separate fuel pellet injection system serves each reactor chamber. The pellets are frozen spheres of D-T weighing $1.3 \mathrm{mg}$. At $100 \% 10 \mathrm{ad}$ factor, the system of 24 reactor cavities requires $2.5 \times 10^{6} \mathrm{pellets} /$ day. This corresponds to a fuel injection rate of $1.9 \mathrm{~kg} /$ day of tritium and $1.3 \mathrm{~kg} /$ day of deuterium. Pellet burnup is $22 \%$, yielding a fuel consumption rate of $0.43 \mathrm{~kg} /$ day of tritium and $0.28 \mathrm{~kg} /$ day of deuterium. The fuel system functions to purify recycled fuel and bred tritium recovered from the blanket, to prepare it in pellet form, and to inject it. The purification system for recycled fuel and bred tritium has not been designed.

The pellet fabrication and fuel injection system is shown in Figure 110. Liquid helium freezes a D-T mixture that is extruded through a die and cut to length by a laser beam. The fuel pellets are injected into the warm reactor chamber at high velocity to minimize pellet vaporization, which quickly makes the pellets spherical. The pellet injector may use pneumatic or electrostatic acceleration. The injected pellets pass through a rotating blowback protection valve which operates synchronously with the pellet injection system. This valve permits passage of the pellet without direct exposure of the injection system to the products of the pellet microexplosion.

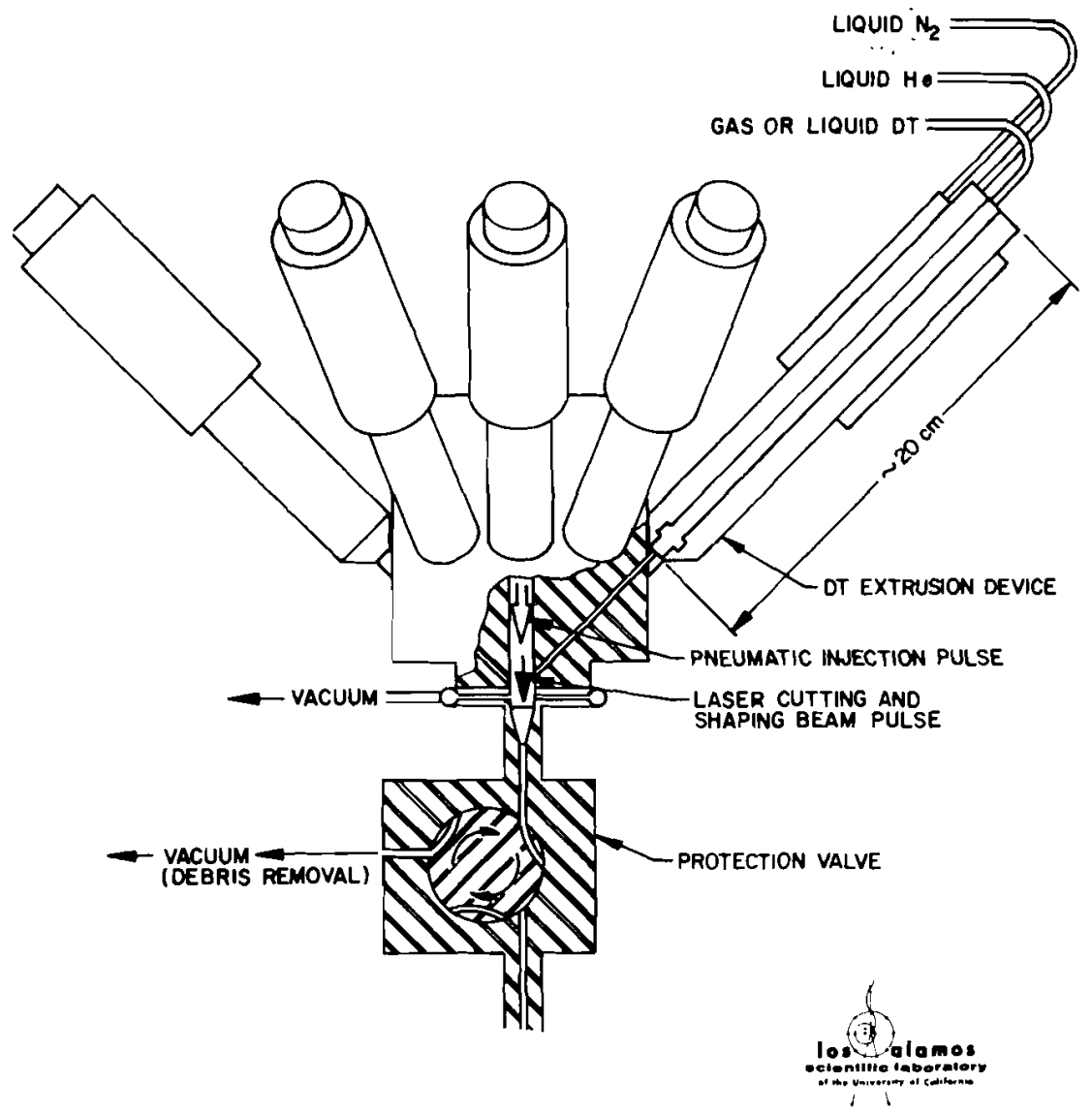

FIGLIRE 110 Pellet Fabrication and Injection System for the LASL Laser-Fusion Reactor 
Blanket for the LASL Laser-Fusion Reactor - In addition to confining the fusion microexplosions, the blanket surrounding the central cavity of each of the 24 reactor chambers must convert neutron energy to heat, breed tritium, and provide for the removal of heat by a coolant. The blanket of a reactor chamber is shown in Figure 105. It surrounds a spherical central cavity of radius $1.7 \mathrm{~m}$. The porous inner wall is made of niobium $1 \mathrm{~cm}$ thick. It supports an inner lithium coating $1 \mathrm{~mm}$ thick which is replenished following ablation by lithium from within the blanket.

The blanket consists primarily of liquid lithium, which acts as primary coolant, neutron moderator, and fertile material (Figure 105). Within the lithium are located a $5 \mathrm{~cm}$ thick inner structural wall and a $10 \mathrm{~cm}$ thick main pressure vessel, both made of stainiess steel. The total thickness of 1 ithium in the blanket is $1.0 \mathrm{~m}$. It is contained within a $2.5 \mathrm{~cm}$ thick outer envelope of stainless steel.

The liquid lithium coolant enters the blanket through a plenum which leads it into the region between the inner structural wall and the chamber inner wall. This low temperature layer replenishes the ablative cavity lining. (The lithium vapor pressure at its entry temperature of $400^{\circ} \mathrm{C}$ is $10^{-4}$ torr, well below the cavity vacuum required for passage of the laser beam.) The inner structural wall and the pressure vessel contain apertures which permit the main lithium flow to travel outward through the blanket into an exit plenum between the pressure vessel and the outer shell.

The inner structural wall serves to support and restrain the inner niobium wall as well as to provide a flow baffle for lithium coolant flow. The main pressure vessel absorbs the pressure pulses caused by the microexplosions, and is the outer restraint for the reactor chamber. The outer shell functions primarily as a coolant flow collection plenum. The lifetime of the blanket structural materials is not estimated. It will be 1 imited by embrittlement due to neutron interactions and by metal fatigue. In addition to cyclic stressing caused by pellet microexplosions, resonant effects producing high frequency ringing of the walls may exacerbate fatigue effects.

Heat Transfer System for the LASL Laser-Fusion Reactor - Liquid lithium, the primary coolant, carries heat that it absorbs in the blanket to external heat exchangers where it is transferred to liquid sodium intermediate coolant. The sodium coolant transfers the heat to steam generators where it is used to raise steam to drive the turbine-generators. Twelve independent lithium/ sodium/steam coolant loops are specified, one for each pair of adjacent reactor chambers.

The lithium primary coolant also functions as a neutron moderator and a fertile material for tritium breeding. Consequently, significant quantities are contained within the reactor chamber blankets, as well as in the primary coolant system. Plant lithium inventory has not been determined. The total plant lithium circulation rate is $1.2 \times 10^{7} \mathrm{~kg} / \mathrm{hr}$. The lithium coolant enters the blanket at $400^{\circ} \mathrm{C}$ and exits at $750^{\circ} \mathrm{C}$. Coolant temperatures were chosen to be compatible with existing steam technology.

The lithium/sodium heat exchangers are constructed of stainless steel. Dimensions are expected to be less than $3 \mathrm{~m}$ in diameter by $3 \mathrm{~m}$ long. Coolant conditions in the sodium and steam systems have not been determined. Steam generators are to use LMFBR technology. Heat exchanger and 
steam generator locations are indicated in Figure 107 and Figure 111. Physical separation of the reactor chambers and of each of the associated liquid metal coolant loops is shown.

Electricity Generation System for the LASL Laser-Fusion Power Plant - Electricity is generated by conventional steam turbine-generators. The gross plant electrical output is 1500 MWe. Of this, 500 MWe is used by lasers and other plant equipment. The net plant output is thus 1000 MWe, produced from $3745 \mathrm{MWt}$. The gross thermal efficiency of generation is $40 \%$ and the net plant efficiency is $27 \%$. Natural draft cooling towers of conventional design are used to dissipate 2730 MWt of waste heat.

Spent Plasma Collection System for the LASL Laser-Fusion Concept - Following each microexplosion, pellet debris, unburned fuel, and radiation impact the lithium inner wall coating, ablating kilogram quantities of lithium. A fraction of the spent plasma remains in the wetted layer; however, most of it probably blows down through the spray condensers and is entrained and absorbed in the lithium pool. The plant production rate of spent plasma is $1.5 \mathrm{~kg} /$ day of tritium, $1.0 \mathrm{~kg} / \mathrm{day}$ of deuterium and $0.58 \mathrm{~kg} /$ day of helium.

Lithium from the spray condenser pool is circulated through an intermediate heat exchanger for the removal of heat (Figure 106). Condensable materials, including unburned fuel in the form of lithium tritide and deuteride, other pellet materials, and ablated wall materials are collected in filtered side stream cold traps operating at about $200^{\circ} \mathrm{C}$. Noncondensable materials, such as hel ium and unburned fuel not absorbed in the 1 ithium are removed from the reactor chambers by vacuum pumps.

Bred Tritium Recovery System for the LASL Laser-Fusion Reactor - The breeding ratio of tritium in the blanket lithium is 1.2 . About $0.5 \mathrm{~kg} /$ day of tritium is bred. Two possibilities for recovery are permeation and cold trapping. The first involves tritium permeation through thin permeable metal windows (e.g., Nb-1\% Zr). This would be accomplished from a side stream taken from the hot leg of the primary coolant loop. The second method uses filtered cold traps to collect LiT from a cold-leg side stream of the primary coolant loop. Tritium inventories for plant systems have not been determined. Tritium flows in the plant are indicated in Figure 112. Containment Building for the LASL Laser-Fusion Design - The reactor building, shown in Figures 107 and 111, provides two levels of containment. Primary containment is provided by a separate concrete cell enclosing each reactor chamber. Secondary containment is provided by the reactor building itself.

Each reactor chamber is in a separate shielded enclosure with penetration for laser beams, 1 iquid lithium coolant, and the introduction of fuel. Heat exchangers and lithium processing equipment for each pair of reactor chambers are located in shielded enclosures adjacent to the reactor chamber enclosures. Walls are constructed of high density concrete.

There are two possibilities for providing tritium containment. A tungsten coating having a low permeability to tritium could be applied to reactor chamber walls and piping. Or, double wall construction could be used, with continuous vacuum pumping of the space between the walls to recover the tritium. 


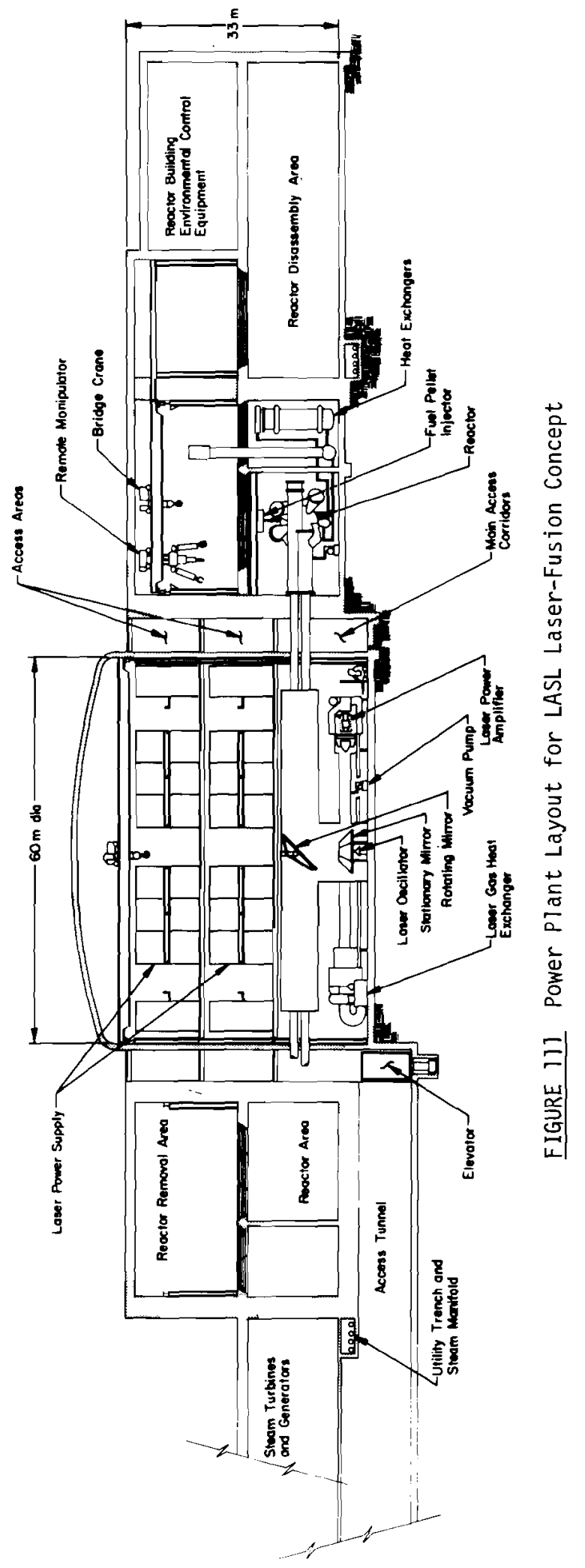




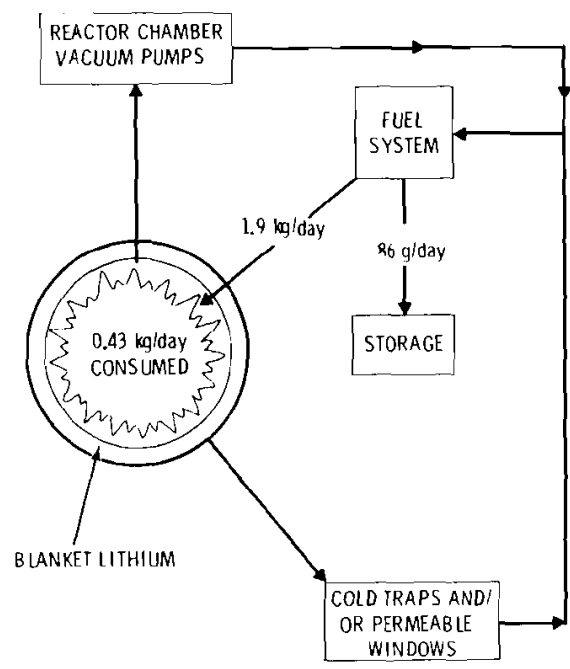

FIGURE 112 Tritium Flow Schematic for the LASL Laser-Fusion Power PIant

The reactor building itself has two parts. The inner region housing the laser systems and components is mechanically isolated from the outer region and anchored to bed rock, to minimize vibrational disturbances.

\subsubsection{Livermore Suppressed Ablation}

Summary Description - The LLL Suppressed Ablation laser-fusion power plant $(12,18)$ produces 270 MWe of net electrical power from an average thermal energy release of 760 MWt. The plant consists of 10 reactor chambers, in each of which pellet microexplosions occur at a rate of 10 per second. Continuous electrical generation is possible even though the thermonuclear burn cycle is pulsed, due to the heat capacity of reactor materials. A conceptual reactor chamber is shown in Figure 113 .

The reactor chambers are cooled by liquid lithium metal, which also functions as a neutron moderator and a fertile material to breed tritium fuel. Heat from this primary coolant is used to generate steam.

Major power plant systems are identified and their functional relations are shown in Figure 114 . The reactor containment building has not been designed and overall power plant layout has not been determined.

The individual reactor chambers are icosahedra as shown in Figure 113, with a maximum 1 inear dimension of about $7 \mathrm{~m}$. The radius of an inscribed sphere is $2.2 \mathrm{~m}$. They are constructed of niobi.um.

The reactor chambers confine the laser-pellet microexplosions each of which releases 7 MJ of energy. A thin layer of lithium forms a protective coating for a porous niobium inner wali, as in the LASL Wetted-Wall design. The concept takes its name from the fact that the ablation of this layer is virtually eliminated by controlling energy deposition on the lithium surface. 


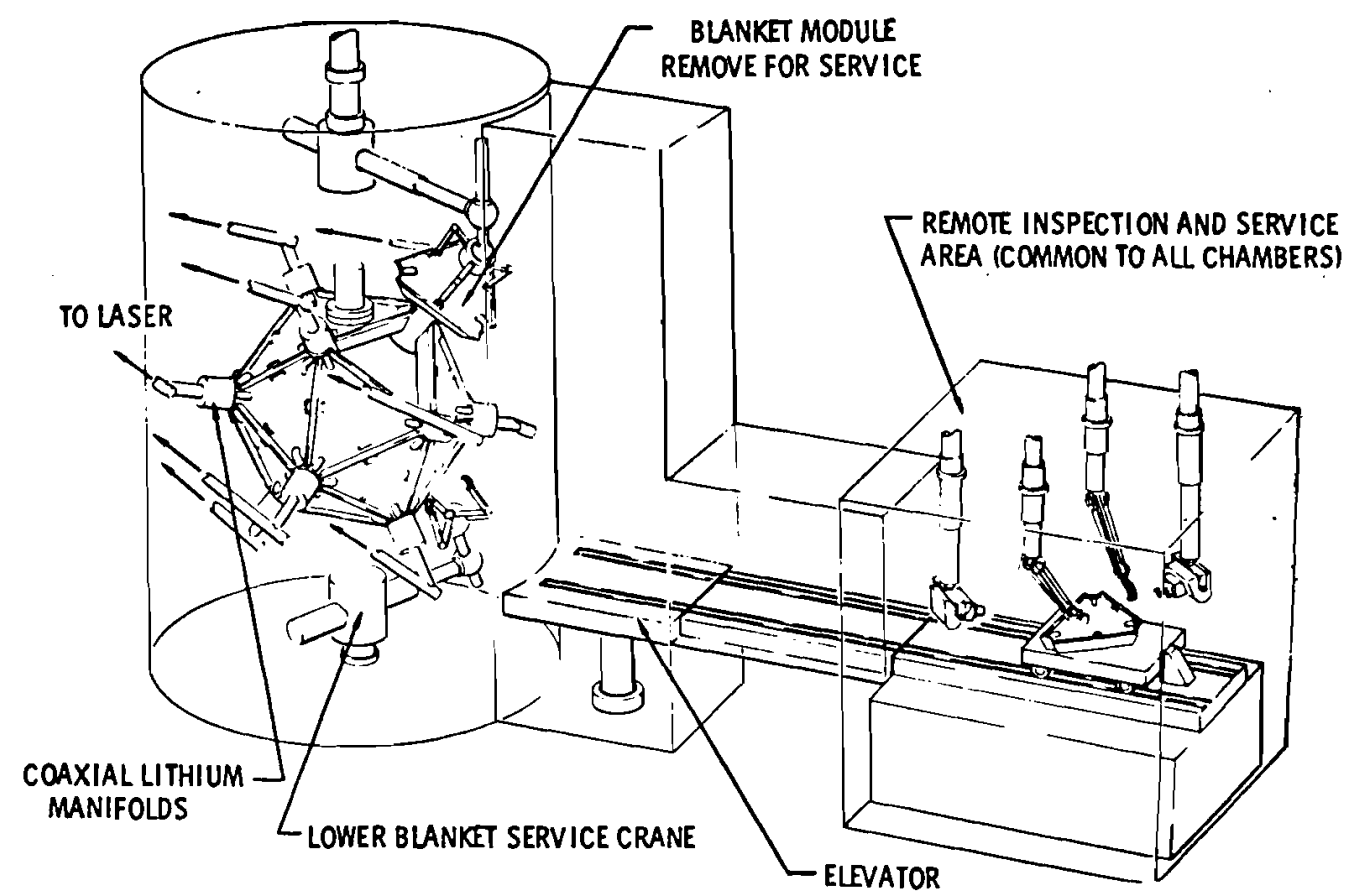

FIGURE 113 Reactor Chamber and Service Assembly of the Suppressed Ablation Laser-Pellet Reactor

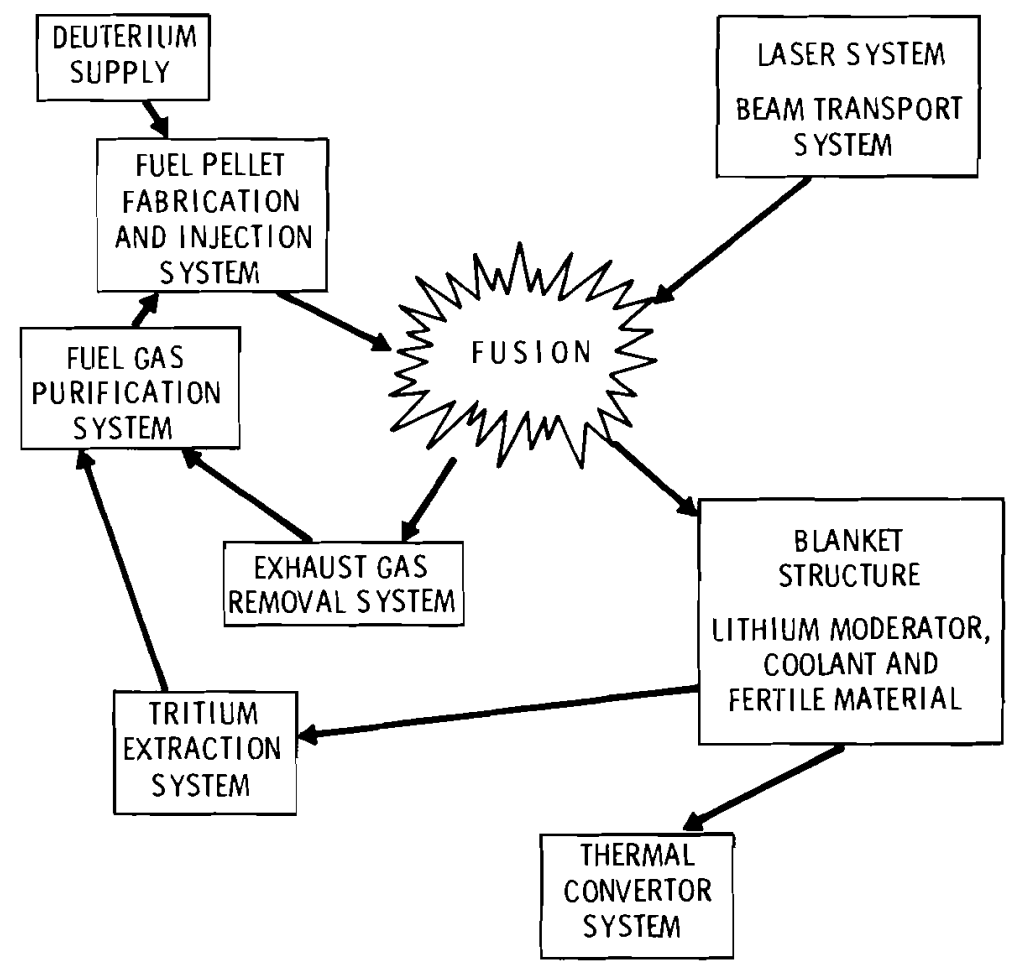

FIGURE 114 Functional Relations Between Systems of the LLL Suppressed Ablation Power Plant 
Ablation suppression minimizes the pressure pulses that must be absorbed by the blanket structure and eliminates the need for cavity blowdown.

Heating of the fuel pellets to ignite the thermonuclear burn is accomplished by separate laser systems for each reactor chamber. Symmetrical pellet irradiation by a single laser amplifier system is achieved by beam splitting, yielding 12 laser beams to be simultaneously focused upon the pellet. The lasers deliver $0.1 \mathrm{MJ}$ of energy to each pellet, each pulsing 10 times per second.

A separate fuel pellet injection system serves each reactor chamber. The pellets are hollow spheres of D-T weighing $0.1 \mathrm{mg}$. At 100\% 1oad factor, the system of 10 reactor chambers requires $8.6 \times 10^{6}$ pellets/day. This corresponds to a fuel injection rate of $0.52 \mathrm{~kg} /$ day of tritium and $0.35 \mathrm{~kg} /$ day of deuterium. Pellet burnup is $21 \%$, yielding a fuel consumption rate of $0.11 \mathrm{~kg} / \mathrm{day}$ of tritium and $0.07 \mathrm{~kg} /$ day of deuterium.

Energy recovery and tritium breeding take place in a $1.0 \mathrm{~m}$ thick blanket surrounding the reactor chamber. The blanket consists primarily of lithium, contained in prism-shaped niobium cells. The ends of the cells facing the plasma are pyramid-shaped to increase the surface area receiving the microexplosion energy. These cells form a honeycomb array within each of the 20 blanket modules which form the faces of the icosahedral reactor chambers. Blanket layout is shown in Figure 115 along with details of the individual niobium cells.

The blanket outlet and inlet temperatures of the 1 ithium primary coolant are $997^{\circ} \mathrm{C}$ and $197^{\circ} \mathrm{C}$. Electricity generation is accomplished at a gross efficiency of $45 \%$. Net plant efficiency is $36 \%$.

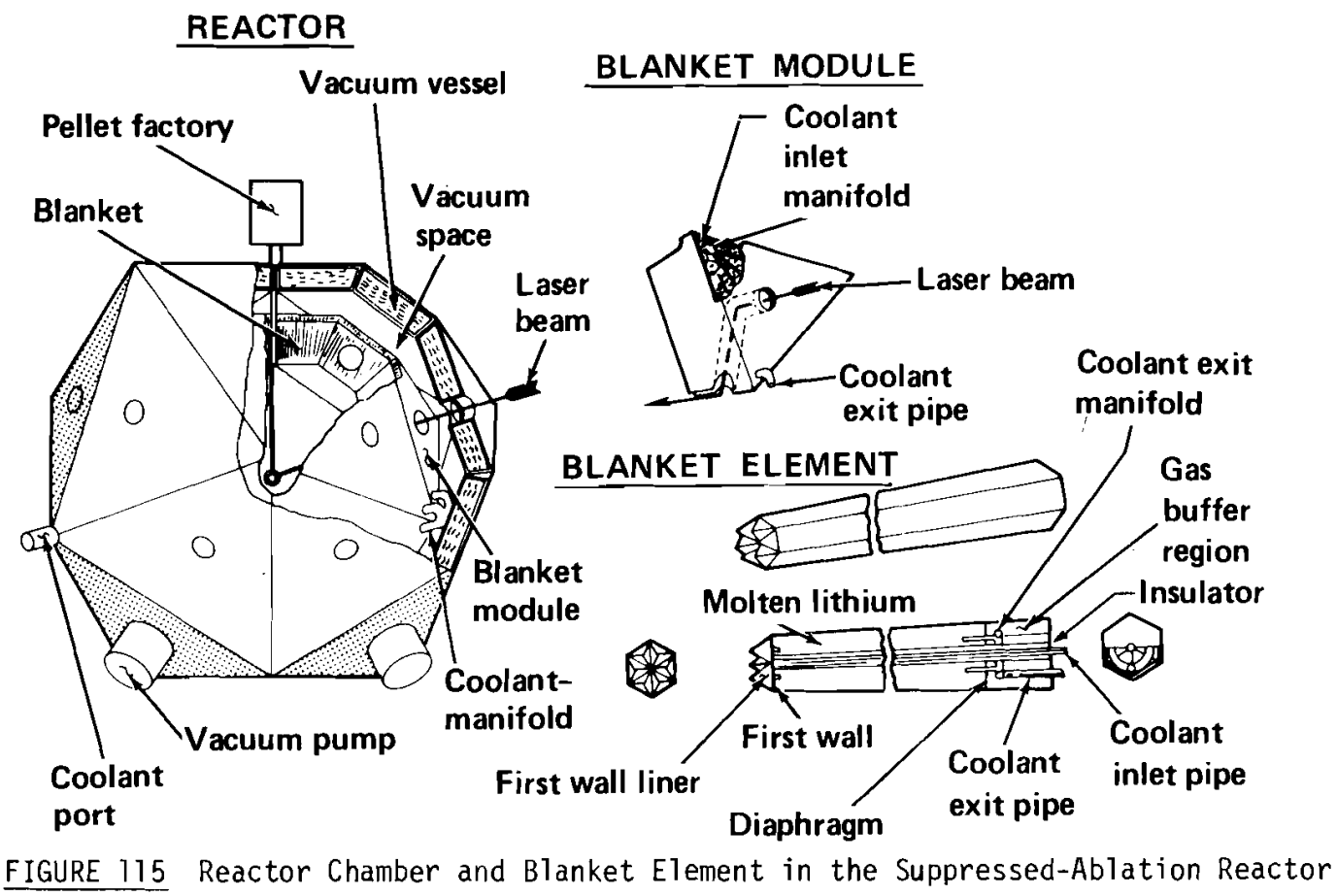


Following the fusion microexplosions spent fuel must be removed from the reactor chambers at the rate of $0.41 \mathrm{~kg} /$ day of tritium, $0.28 \mathrm{~kg} /$ day of deuterium and $0.03 \mathrm{~kg} /$ day of helium. A fraction is entrained in the lithium coating the chamber inner wall and the remainder is collected by vacuum pumps along with lithium vapor.

About $0.16 \mathrm{~kg} /$ day of tritium is bred in the lithium coolant/fertile material at a breeding ratio of 1.45. The recovery method for tritium, and that absorbed through the inner wa11, has not been determined; therefore, tritium inventories for the plant systems are not known.

Plasma Confinement System for the LLL Laser-Fusion Design - After the microexplosion, the hot plasma expands rapidly and impacts the surface of the reactor chamber that confines $i t$. About $24 \%$ of each $7 \mathrm{MJ}$ microexplosion is deposited on the reactor chamber inner surface. This inner surface consists of an ablative layer of liquid lithium $0.3 \mathrm{~mm}$ thick on a porous niobium sheet $0.4 \mathrm{~mm}$ thick. The surface area of this inner wall is maximized by corrugating it into pyramid shapes which face the plasma. Energy deposition on this surface is about $1 \mathrm{~J} / \mathrm{cm}^{2}$ per pulse, almost two orders of magnitude lower than for the Wetted-wall design.

Deposition of charged particle energy from the fusion microexplosions on the inner wall surface occurs in about one microsecond, raising the surface temperature to a peak of $1097^{\circ} \mathrm{C}$ and vaporizing just $0.34 \mathrm{~g}$ of lithium from the entire surface. A peak wal1 pressure of $90 \mathrm{millibars}$ is expected, which will be supported by the inner wall itself.

Plasma Heating System for the LLL Laser-Fusion Design - Ten separate laser systems are required for fuel pellet irradiation, one for each reactor chamber. The laser amplifier system at each chamber delivers $0.1 \mathrm{MJ}$ of energy to each pellet through a beam splitting arrangement which provides 12 separate laser beams. Symmetrical pellet irradiation is achieved by introducing these beams into the reactor chambers at the vertices of the icosahedral chambers (Figure 113). A gas laser system using an undetermined gas is to deliver each 0.1 MJ pulse within a few nanoseconds. The time-shaped laser pulse will have a peak power of 50 torrawatts, and a wavelength between 0.3 and $0.6 \mathrm{\mu m}$. The system is assumed to be $10 \%$ efficient, requiring a total of 100 MWe of recirculated electrical power.

The laser beams are to be introduced into the reactor chambers through windows. To prevent damage to these windows by the laser pulses, each must have an area of $0.2 \mathrm{~m}^{2}$. The laser beam tubes are bent through dog-legs within the blanket to prevent radiation streaming through them (Figure 115). The final focusing mirrors that are exposed to the microexplosion effects have a renewable lithium coating fed by capillary action through a niobium substrate.

Fuel System for LLL Laser-Fusion Design - A separate fuel pellet injection system serves each reactor chamber. The pellets are hollow spheres of D-T weighing $0.1 \mathrm{mg}$. At 100\% 1oad factor, the system of 10 reactor chambers requires $8.6 \times 10^{6}$ pellets/day. The fuel injection rate is $0.52 \mathrm{~kg} /$ day of tritium and $0.35 \mathrm{~kg} /$ day of deuterium. Pellet burnup is $21 \%$, yielding a fuel consumption rate of $0.11 \mathrm{~kg} /$ day of tritium and $0.07 \mathrm{~kg} /$ day of deuterium.

The fuel system purifies recycled fuel and bred tritium recovered from the blanket, to prepare it in pellet form, and to inject it. The purification system for recycled fuel and bred tritium has not been designed. 
Fuel pellets are injected into the reactor chambers at a velocity of about $45 \mathrm{~m} / \mathrm{sec}$ by a helium gas gun. Helium gas at $20^{\circ} \mathrm{K}$ is used at a breech pressure of 7.3 torr. About $2 \times 10^{-5} \mathrm{~g}$ of helium, which is not expected to cause vacuum pumping problems, is introduced into the reactor chamber per shot.

Pellet steering after injection may be accomplished electrostatically or by slight ablation of the pellet surface by laser light. The pellet velocity can be checked by passing it through a narrow laser beam twice, using two right angle prisms and a photocell. Connecting the output of the photocell to a process control computer will allow precise computation of pellet velocity and laser firing time.

Blanket for the LLL Laser-Fusion Design - In addition to confining the fusion microexplosions, the blanket surrounding the central cavity of each of the 10 reactor chambers must convert neutron energy to heat, breed tritium, and provide for the removal of heat by a coolant.

The individual reactor chambers are icosahedra, as shown in Figure 113, with a maximum 1 inear dimension of about $7 \mathrm{~m}$. The radius of an inscribed sphere is $2.2 \mathrm{~m}$. They are constructed of niobium and contain liquid lithium metal, which acts as primary coolant, neutron moderator, and fertile material for tritium breeding.

The blanket is of modular construction, with each of the 20 faces of the icosahedral reactor chambers being a main blanket module. Each of the main modules contains a honeycomb array of equilateral triangular-shaped unit cells approximately $1 \mathrm{~m}$ in length. The unit cells (Figure 115) are fabricated from niobium sheet, and contain liquid lithium. The top of a unit cell is pyramid shaped and forms part of the reactor chamber first wall. It is made from porous niobium sheet $0.4 \mathrm{~mm}$ thick, and supports an inner 1 ithium layer $0.3 \mathrm{~mm}$ thick which is maintained by capillary action from lithium within the unit cell. At the base of the blanket a diaphragm separates the lithium from a buffer gas which is used to damp out the vibrations from pressure pulses created in the lithium by deposition of the microexplosion neutron energy. Cellular blanket construction provides good structural strength, allows repair by replacement of unit cells, and allows access to the chamber cavity for laser beams or instrumentation by removal of one or more unit cells.

Liquid lithium primary coolant entering the blanket is directed first to the inner wal1 region. It then enters the blanket cells, passes outward through them, and is piped from the blanket.

The power density achieved in the reactor chamber blankets is comparable to that in the wetted wall blankets, despite the ten-fold reduction in microexplosion energy release. This is possible because of the higher microexplosion rate allowed by the suppressed ablation of lithium vapor which has to be removed from the reactor chamber between microexplosions. Because each microexplosion deposits less energy in the blanket, thermal expansion pulses are reduced aiong with associated structural stress and vibration problems. No estimate has been made of the lifetime limitations of blanket structures due to radiation damage or fatigue.

Heat Transfer System for the LLL Laser-Fusion Design - Liquid lithium is the primary coolant. The remainder of the heat transfer system has not been determined. 
The lithium primary coolant also functions as a neutron moderator and a fertile material for tritium breeding. Consequently, significant quantities are contained within the reactor chamber blankets, as well as in the primary coolant system. The plant lithium inventory has not been determined. The total plant lithium circulation rate is $8.3 \times 10^{5} \mathrm{~kg} / \mathrm{hr}$.

The lithium coolant enters the blanket at $197^{\circ} \mathrm{C}$ and leaves it at $997^{\circ} \mathrm{C}$. Coolant pressure is not specified.

Electricity Generation - Electricity is generated by a standard thermal conversion system. The gross plant electrical output is 370 MWe. Of this, 95 MWe is used by lasers and other plant equipment. The net plant output is thus 275 MWe, produced from 760 MWt. The gross thermal efficiency of generation is $48 \%$, and the net plant efficiency is $36 \%$. Figure 116 is a flow diagram for the plant.

Spent Plasma Collection System for the LLL Laser-Fusion Design - Following each fusion microexplosion, pellet debris, unburned fuel, and radiation impact the lithium inner wall coating, ablating about $0.34 \mathrm{~g}$ of 1 ithium vapor. The plant production rate of spent plasma is $0.41 \mathrm{~kg} / \mathrm{day}$ of tritium, $0.28 \mathrm{~kg} /$ day of deuterium, and $0.03 \mathrm{~kg} /$ day of helium. A fraction of the unburned fuel is absorbed in the lithium inner wall coating, and the remainder is removed from the chamber by vacuum pumps, along with the helium and the lithium vapor. The vacuum system maintains a chamber pressure of 0.1 torr. This requires a pumping speed of $3 \times 10^{5}$ 1iters $/ \mathrm{sec}$ per chamber, arid recirculation of $0.5 \%$ of the plant electrical output to the pumps.

Unburned fuel which is absorbed in the lithium wall coating either permeates into the blanket, for recovery with bred tritium, or is vaporized with the lithium in succeeding microexplosions, for recovery by the vacuum system.

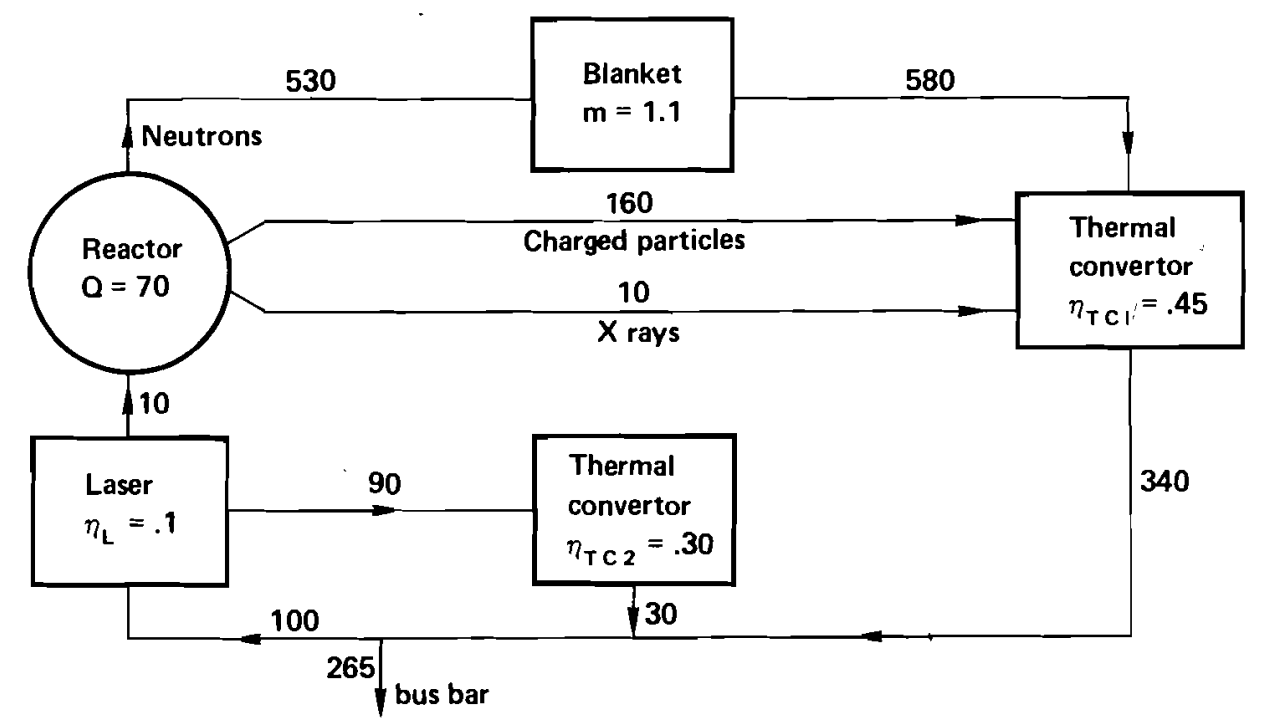

FIGURE 116 Power Flow Diagram for a Laser-Induced Fusion Reactor Power Plant Consisting of 10 Reactors. (A11 powers are in megawatts.) 
Bred Tritium Recovery System for the LLL Laser-Fusion Design - The breeding ratio of tritium in the blanket lithium is 1.45 . About $0.16 \mathrm{~kg} /$ day of tritium is bred. The recovery system has not been defined. Tritium inventories for plant systems have not been determined. Tritium flows in the plant are indicated in Figure 117.

Containment Building for the LLL Laser-Fusion Design - The reactor building housing the 10 reactor chambers and the common inspection and service area (Figure 113) has not been designed. It is noted, however, that the fuel pellet injectors will be shock-mounted on a massive structure independent of the reactor chambers, to reduce vibration transmission.

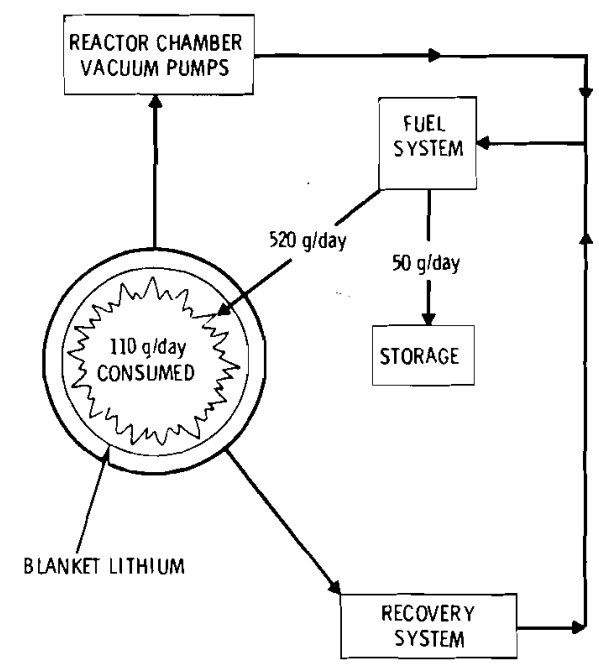

FIGURE 117 Tritium Flow Schematic for LLL Laser-Fusion Design 


\subsection{RESEARCH REQUIRED}

The environmental effects of power plant operation depend strongly on design details. In addition to the reactor itself, the design of support systems, waste systems, balance-of-plant systems, and the containment are of fundamental importance. The present generation of power plant designs was prepared to identify research and technology development necessary to allow the design of realistic fusion power plants. Consequently the designs are inadequate in areas where present technology is inadequate. A recent workshop* has produced extensive recommendations of needed research. System flows and inventories, physical dimensions and locations, and even basic processes, must be specified much more completely before effluent releases and other environmental interactions can be predicted with confidence.

A complete environmental analysis of a power plant design requires the study of 16 interactions of the plant with the environment. These interactions are listed in Table 17, with the types of information which the power plant design document must include so that the interactions can be evaluated.

other documents in this series, containing more specific discussions of information needed to analyze the environmental interactions of power plant operation under normal conditions, are indicated in Table 17. Safety analysis also requires detailed knowledge of system layout, flows, inventories and stored energies. Additional discussion of information needed for safety analyses is contained in BNWL-2024.

Design criteria need to be developed for fusion reactor containment buildings. Containment design is sketchy, or omitted, in most designs. Because the containment acts as the final physical barrier against releases, functional objectives need to be established for its performance.

Containment buildings represent a large commitment of resources (concrete and iron reinforcement rods primarily) compared with total plant requirements. Development of design criteria would help to put designs on a common basis, and should help to reduce the spread in materials requirements.

A complete fusion power plant design optimized for minimal usage of primary materials per MWe of plant capacity should be developed. Requirements of primary elements per MWe vary by an order of magnitude among the designs, due to differences in the design concepts, and to differences in design completeness. In Table 6 maximum material requirements for plant construction are seen to be several times larger than requirements for LMFBR-based plants. A design study optimized for minimal material usage would help to identify the extent to which the spread in materials requirements for present designs stems from differences in design completeness. It would also reduce uncertainties in estimates of resource commitments for fusion power plants as compared to al ternatives.

A standard format for description of fusion power plant designs should be established irmediately to facilitate intercomparison of design concepts. The functiondliy-based descriptive format used

\footnotetext{
* Study Session Summaries, Workshop on Fusion Blanket and Shield Technology, Brookhaven Nationa 1 Laboratory, March 29 - April 2, 1976.
} 
TABLE 17 Environmental Interactions, and Design Information Required for Their Analys is*

Environmental Interactions

Land use

Labor use

Material use

Heat releases

Chemical releases

Sanitary waste releases

Noises

Vibrations

Odors

Magnetic fields

Liquid releases

Solid waste disposal

Gaseous waste disposal

Radionuclide disposal

Aesthetic effects

Material transportation
Information Required for Analysis (a)

Land area for power station and supporting facilities. (BNWL-2015)

Construction force schedule. Operating crew size. (BNWL-2010)

Quantities of each construction and operating material (BNWL-2012 and 2016)

Net Power Plant electrical output. Power plant thermal efficiency. General design of heat disposal systems. (BNWL-2017)

General design of heat disposal systems. General design of any waste treatment system for process chemicals. Composition, flow rates and locations of waste streams containing chemicals. (BNWL-2010)

Number of personnel. (BNWL-2010)

Identification of noticeable noises at plant boundaries. (BNWL-2010)

Identification of noticeable vibrations at plant boundaries. (BNWL-2010)

Identification of abnormal odors at plant boundaries. (BNWL-2010)

Description of magnetic field locations and strengths in inhabited areas. (BNWL-2021)

General design of heat disposal system. General design of 1 iquid waste disposal systems. Composition, flow rates and locations of liquid effluents. (BNWL-2010)

Amounts of solid wastes. (BNWL-2010)

General design of ventilation system. General design of gaseous waste disposal systems. Composition, flow rates and locations of gaseous effluents. (BNWL-2010)

General design of ventilation system. General design of liquid, gaseous, and solid radwaste systems. Quantities generated and flow paths for radionuclides. Designs of equipment controlling radionuclide travel paths. (BNWL-2018, 2019, and 2020)

General plant plot plan, isometric view of plant. (BNWL-2010) Quantities of material transported and method of transportation. (BNWL-2025)

a. More specific discussion of needed information is included in the documents indicated in parenthesis.

in this document could serve as a starting point. Furthermore, design documents should present such descriptions in clearly identified chapters or sections, separated from supporting theory, data and calculational results forming the basis and justification for the design. The discipline of stating simply what has been achieved in each design study would help to reduce ambiguity. An additional advantage of using a standard descriptive format is that it would facilitate identification of plant elements not included in the design and therefore omitted from estimates of materials requirements and costs.

* BNWL document titles listed in Preface. 


\section{ACKNOWLEDGEMENTS}

The preparation of preliminary draft descriptions of individual power plant designs by

R. G. Clark, S. R. Wagoner, D. A. Waite and W. C. Wolkenhauer is gratefully acknowledged.

Thanks are extended to the authors of the various design documents for permission to reproduce

their illustrations. Reviews of the descriptions by authors at Brookhaven, Los Alamos, Livermore, 0ak Ridge and Princeton are also gratefully acknowledged. 


\section{REFERENCES}

1. J. R. Young and B. F. Gore, Reference Commercial Fusion Power Plants, BNWL-2014, Battelle, Pacific Northwest Laboratories, Richland, WA, 1976.

2. E. S. Murphy, Review of Fusion Research Program, BNWL-2011, Battelle, Pacific Northwest Laboratories, Richland, WA, 1976.

3. B. Badger, et a 1., (30 authors), UWMAK-I, A Wisconsin Toroidal Fusion Reactor Design, UWFDM-68, University of Wisconsin, Madison, WI, Vol. I (1974) and II (1975).

4. B. Badger, et al., ( 30 authors), UWMAK-II, A Conceptual Tokamak Power Reactor Design, UWFDM-112, University of Wisconsin, Madison, WI, October 1975.

5. J. R. Powell, Ed., "Preliminary Reference Design of a Fusion Reactor Exhibiting Very Low Residual Radioactivity," BNL-19565, Brookhaven National Lab., December 1974.

6. A Fusion Power Plant, R. G. Mills, Ed., MATT-1050, Princeton Plasma Physics Laboratory, 1974.

7. A. P. Fraas, Conceptual Design of the Blanket and Shield Region and Related Systems for a Full Scale Toroidal Fusion Reactor, ORNL-TM-3096, Oak Ridge National Laboratory, May 1973.

8. J. E. Draley, R. A. Krakowski, T. A. Coultas, and V. A. Maroni, An Engineering Design Study of a Reference Theta-Pinch Reactor (RTPR): Environmental Impact Study, LA-5336, Los ATamos National Laboratory, Vol. II, March 1975.

9. R. W. Werner, G. A. Carlson, J. Hovingh, J. D. Lee and M. A. Peterson, Progress Report \#2 on the Design Considerations for a Low Power Experimental Mirror Fusion Reactor, UCRL-74054-2, September 1973.

10. A. P. Fraas, Conceptual Design of a Series of Laser Fusion Power Plants of 100 to $3000 \mathrm{MW}(\mathrm{e})$, Oak Ridge National Laboratory, Oak Ridge, TN. Paper presented at the 9th Intersociety Energy Conversion Engineering Conference, San Francisco, CA, August 26-30, 1974.

11. J. Williams, T. Merson, F. Finch, F. Schilling, and T. Frank, A Conceptual Laser Controlled Thermonuclear Reactor Power Plant, LA-UR-74-593, Los Alamos Scientific Laboratory, Los Alamos, NM, April 1974.

12. J. Hovingh, J. Maniscalco, M. Peterson and R. W. Werner, "The Preliminary Design of a Suppressed Ablation Laser-Induced Fusion Reactor, "Proceedings of the First Topical Meeting on the Technology of Controlled Nuclear Fusion. Aprit 16-18, 1974, San Diego, CA, CONF-740402-P1, p. 96 .

13. A. P. Fraas, Comparative Study of the More Promising Combinations of Blanket Materials, Power Conversion Systems, and Tritium Recovery and Containment Systems for Fusion Reactors, ORNL-TM-4999, Oak Ridge National Laboratory, Oak Ridge, TN, November 1975.

14. A. P. Fraas, The Blascon - An Exploding Pel let Fusion Reactor, ORNL-TM-3231, Oak Ridge National Laboratory, Oak Ridge, TN, JuTy 1971.

15. M. J. Lubin and A. P. Fraas, "Fusion by Laser," Scientific American, Vol. 224, 6, 21, June 1971 .

16. L. A. Booth, compiler, Central Station Power Generation by Laser Driven Fusion, LA-4858-MS, Vol. 1, Los Alamos Scientific Laboratory, Los Alamos, NM, February 1972.

17. F. T. Finch, E. A. Kern, and J. M. Williams, Laser Fusion Power Plant System Anatysis, LA-UR-74-580, Los Alamos Scientific Laboratory, Los Alamos, NM, Aprí1 1974.

18. J. Nuckolls, J. Emmett, and L. Wood, "Laser-Induced Thermonuclear Fusion," Physics Today, Vo1. $26,8,46$, August 1973. 
A. A. Churm ERDA Chicago Patent Group

9800 S. Cass Avenue

Argonne, IL 60439

J. W. Beal

ERDA Div. of Magnetic Fusion Energy Washington, DC 20545

S. 0. Dean

ERDA Div. of Magnetic Fusion Energy Washington, DC 20545

E. E. Kintner

ERDA Div. of Magnetic Fusion Energy Washington, DC 20545

J. M. Williams ERDA Div. of Magnetic Fusion Energy Washington, DC 20545

J. N. Grace

ERDA Div. of Magnetic Fusion Energy

Washington, DC 20545

J. Baublitz

ERDA Div. of Magnetic Fusion Energy Washington, DC 20545

3 F. E. Coffman

ERDA Div. of Magnetic Fusion Energy Washington, DC 20545

J. F. Decker ERDA Div. of Magnetic Fusion Energy Washington, DC 20545

3 K. M. Zwilsky

ERDA Div. of Magnetic Fusion Energy

Washington, DC 20545

Dr. Philip M. Stone ERDA Applied Plasma Physics Program

Washington, DC 20545

G. W. Kuswa

ERDA Div. of Laser Fusion

Washington, DC 20545
OFFSITE

R. Blaunstein

ERDA Div. of Biomedical and Environmental Research Washington, DC 20545

H. M. Busey

ERDA Div. of Military

Application

Washington, DC 20545

M. A. Bell

ERDA Div. of Safety

Standards and Compliance

washington, DC 20545

27 ERDA Technical Information Center

M. S. Kaminsky

Argonne National Laboratory

9700 S. Cass Avenue

Argonne, IL 60439

V. A. Maroni

Argonne National Laboratory

$9700 \mathrm{~S}$. Cass Avenue

Argonne, IL 60439

P. M. Persiani

Argonne National Laboratory

9700 S. Cass Avenue

Argonne, IL 60439

M. Petrick

Engineering and Technology Division

Argonne National Laboratory

$9700 \mathrm{~S}$. Cass Avenue

Argonne, IL 60439

W. E. Parkins, Manager

Atomics International

Component Engineering and

Technology Division

North American Rockwel?

P.0. Box 309

Canoga Park, CA 91304

D. Gurinsky

Brookhaven National Laboratory ERDA Brookhaven Area Office Upton, NY 11973

H. J. Kouts

Brookhaven National Laboratory ERDA Brookhaven Area Office Upton, NY 11973

S. Pearlstein

Brookhaven National Laboratory ERDA Brookhaven Area Office Upton, NY 11973
OFFSITE

J. R. Powell

Brookhaven National Laboratory ERDA Brookhaven Area Office Upton, NY 11973

A. J. Impink, Jr.

Carnegie Mellon University

Pittsburgh, PA 15213

R. A. Gross

Plasma Research Laboratory

236 SW Mudd B1dg.

Columbia University

New York, NY 10027

W. C. Gough

Electric Power Research Inst.

3412 Hillview Ave.

Palo Alto, CA 94304

G. R. Hopkins

Gulf General Atomic

P.0. Box 1111

San Diego, CA 92112

Zeinab Sabri

Iowa State University

261 Sweeney Hall

Nuclear Engineering Department

Ames, IA 50010

R. Borg

Lawrence Livermore Laboratory

P.0. Box 808

Livermore, CA 94550

T. K. Fowler

Lawrence Livermore Laboratory

P.0. Box 808

Livermore, CA 94550

R. Moir

Lawrence Livermore Laboratory

P.0. Box 808

Livermore, CA 94550

A. Carl Haussmann

Lawrence Livermore Laboratory

P.0. Box 808

Livermore, CA 94550

J. Hovingh

Lawrence Livermore Laboratory

P.0. Box 808

Livermore, CA 94550

R. F. Post

Lawrence Livermore Laboratory

P.0. Box 808

Livermore, CA 94550

C. J. Taylor

Lawrence Livermore Laboratory

P.0. Box 808

Livermore, CA 94550 
R. Werner

Lawrence Livermore

Laboratory

P.0. Box 808

Livermore, CA 94550

L. L. Wood

Lawrence Livermore

Laboratory

P.0. Box 808

Livermore, CA 94550

W. Bauer

Division Supervisor

of Physical Research

Sandia Labs Livermore

Livermore, CA 94550

L. Booth

Los Alamos Scientific

Laboratory

CTN Research

P.0. Box 1663

Los Alamos, NM 87544

D. J. Dudziak

Los Alamos Scientific Laboratory

CTN Research

P.0. Box 1663

Los Alamos, NM 87544

D. B. Henderson

Los Alamos Scientific

Laboratory

CTN Research

P.0. Box 1663

Los Alamos, NM 87544

E. L. Kemp

Los Alamos Scientific

Laboratory

CTN Research

P.0. Box 1663

Los Alamos, NM 87544

F. L. Ribe

Los Alamos Scientific

Laboratory

CTN Research

P.0. Box 1663

Los Alamos, NM 87544

L. Stewart

Los Alamos Scientific

Laboratory

CTN Research

P.0. Box 1663

Los Alamos, NM 87544

K. Thomassen

Los Alamos Scientific

Laboratory

CTN Research

P.0. Box 1663

Los Alamos, NM 87544
0. K. Harling

Massachusetts Institute of

Technology

Cambridge, MA 02139

Bruno Coppi

Department of Physics

Massachusetts Institute of

Technology

Cambridge, MA 02139

L. Lidsky

Dept. of Nuclear Engineering

Massachusetts Institute of

Technology

Cambridge, MA 02139

Norm Rasmussen

Dept. of Nuclear Engineering

Massachusetts Institute of

Technology

Cambridge, MA 02139

David Rose

Massachusetts Institute of

Technology

Cambridge, MA 02139

R. E. Stickney

Mechanical Engineering

Massachusetts Institute of

Technology

Cambridge, MA 02139

J. J. Reinmann

NASA - Lewis Research Center

2100 Bookpark Rd.

Cleveland, $\mathrm{OH} 44135$

Vincent Arp

National Bureau of Standards

Cryogenics Division

Boulder, CO 80302

J. F. Clarke

Oak Ridge National

Laboratory

P.0. Box Y

Oak Ridge, TN 37830

A. P. Fraas

Oak Ridge National

Laboratory

P.0. Box Y

Oak Ridge, TN 37830

J. Rand McNally, Jr.

Oak Ridge Nationa?

Laboratory

P.0. Box $Y$

Oak Ridge, TN 37830

D. Steiner

Dak Ridge Nationa 1

Laboratory

P.0. Box $Y$

Oak Ridge, TN 37830
J. $S \cot t$

Oak Ridge National Laboratory

P. 0. Box X

Oak Ridge, TN 37830

J. Banford

Physics International

2700 Merced St.

San Leandro, CA 94577

R. A. Huse

Public Service Electric

and Gas Co.

80 Park Place

Newark, NJ 07101

M. Gottlieb

Princeton University, PPPL

P.0. Box 451

Princeton, NJ 08540

R. G. Mills

Princeton University

P.0. Box 451

Princeton, NJ 08540

E. C. Tanner

Princeton University

P.0. Box 451

Princeton, NJ 08540

H. Perkins

Dept. of Chemistry

Princeton University

Princeton, NJ 06540

R. E. Gold

303 Sayre Hall

Forrestal Campus

P.0. Box 451

Princeton, NJ 06540

M. Kristiansen

Texas Tech. University

Lubbock, TX 79409

A. F. Haught

United Aircraft Research Lab.

United Aircraft Corporation

East Hartford, CT 06108

L. Levine

U.S. Naval Research Laboratory Washington, DC 20390

C. Z. Serpan, Jr

U.S. Naval Research Laboratory Washington, OC 20390

Francis Chen

University of California

Electronics Research

Laboratory

College of Engineering

Berkeley, CA 94720 
A. J. Lichtenberg University of California Electronics Research Laboratory

College of Engineering

Berkeley, CA 94720

Dave Okrent

U.C.L.A.

Los Angeles, CA 90024

C. D. Hendricks University of Illinois

Nuclear Engineering

Laboratory

Urbana, IL 61801

G. H. Miley

University of Illinois

Nuclear Engineering

Laboratory

Urbana, IL 61801

Terry Kammash

University of Michigan

Nuclear Engineering

Department

Ann Arbor, MI 48105

Dean Abrahamson

University of Minnesota

School of Public

Affairs

Social Science

Building/309

Minneapolis, MN 55455

W. G. Davey

University of Texas

Department of Physics

Austin, TX 78712

E. Linn Draper, Jr. University of Texas Department of Physics

Austin, TX 78712

W. E. Drummond University of Texas Department of Physics Austir, TX 78712

Abraham Hertzberg University of Washington

Aerospace Research

Laboratory

316 Guggenheim

Seattle, WA 98105

A. L. Babb

University of Washington

Nuclear Eng ineering

Department

Seattle, WA 98105

R. Conn

University of Wisconsin

Nuclear Engineering

Department

Madison, WI 53706

G. L. Kulcinski

University of Wisconsin Nuclear Eng ineering

Department

Madison, WI 53706

C. W. Maynard

University of Wisconsin Nuclear Engineering

Department

Madison, WI 53706

D. Lichtman

Department of Physics University of Wisconsin Milwaukee, WE 53201

E. E. Donaldson Washington State University Deparment of Physics Pullman, WA 99163

D. D. Mahlum Division of Biomedical and Environmental Research Washington, DC 20545

J. V. Vanston Engineering Science Building University of Texas Austin, TX 78712

Les 1 ie S. Ramsey 450 North 5 th Street Indiana, PA 15701 
ERDA Richland Operations Dffice

W. A. Burns

Atlantic Richfield Hanford Company

J. D. Kaser

Hanford Engineering Deve Topment Labs

D. G. Doran

H. H. Yoshikawa

Battelle-Northwest

D. T. Aase

G. S. Allison

T. W. Ambrose

D. G. Atteridge

D. A. Baker

J. L. Bates

M. A. Bayne

E. R. Bradley

J. L. Brimhall

R. L. Brodzinski

R. J. Brouns

L. R. Bunnell

L. L. Burger

S. H. Bush

N. E. Carter

T. D. Chikalla

R. G. Clark

T. L. Criswell

S. D. Dahlgren

M. T. Dana

D. E. Deonigi

R. L. Dillon

D. A. Dingee

P. J. Dionne

B. H. Duarle

J. W. Finnigan

J. C. Fox

J. J. Fuquay

J. E. Garnier

R. D. Gastil

10 B. F. Gore

J. N. Hartley

A. J. Haverfield

U. P. Jenquin

A. B. Johnson, Jr.

R. H. Jones

T. J. Kabele

W. S. Kelly

H. E. Kissinger

D. A. Kottwitz

N. Laegried

B. R. Leonard, Jr

D. L. Lessor

H. B. Liemohn

R. C. Lijkala

M. A. Mckinnon

R. F. Maness

R. P. Marshall
Battelle-Northwest - Cont inued

E. S. Murphy

$R$. D. Helson

D. F. Newman

R. E. Nightingale

D. E. Olesen

L. T. Pedersen

R. T. Perry

D. R. Pratt

L. A. Rancitelli

J. F. Remark

U. S. Renné

R. E. Rhoads

W. D. Richmond

W. F. Sandusky

L. C. Schmid

iv. M. Sherer

E. P. Simonen

R. 1. Smith

J. K. Soldat

C. W. Stewart

K. B. Stewart

R. W. Stewart

J. A. Strand

D. L. Styris

A. M. Sutey

V. L. Teofilo

G. L. Tingey

M. T. Thomas

R. C. Thompson

L. H. Toburen

T. J. Trapp

R. Wang

R. E. Westerman

L. D. Williams

10 J. R. Young

M. G. Zimmerman

1 Technical Publications (BH)

5 Technical Information 